\title{
Distributions and Movements of Atlantic Shark Species: A 52-Year Retrospective Atlas of Mark and Recapture Data
}

\author{
NANCY E. KOHLER and PATRICIA A. TURNER
}

\section{Introduction}

The National Marine Fisheries Service (NMFS) Cooperative Shark Tagging Program (CSTP) is one of the largest and longest running shark tagging programs in the world. The CSTP is a collaborative effort among recreational anglers, the commercial fishing industry, biologists, and the NMFS to study the life history of sharks in the Atlantic Ocean. Initiated in 1962 by John G. Casey, volunteer participation began with an original group of 74 anglers involved in tagging feasibility studies in 1963 . The program expanded in subsequent years to include volunteers distributed along the entire North American and European Atlantic coasts including the Gulf of Mexico. The 52-year database represents the efforts of thousands of partici-

Nancy E. Kohler (retired) and Patricia A. Turner (retired) were with the National Marine Fisheries Service, NOAA, Northeast Fisheries Science Center, Narragansett Laboratory, 28 Tarzwell Drive, Narragansett, RI 02882-1199 (email sharkrecap@gmail.com).

doi: https://doi.org/10.7755/MFR.81.2.1

ABSTRACT-The National Marine Fisheries Service (NMFS) Cooperative Shark Tagging Program (CSTP) was initiated in 1962 as a collaborative effort between recreational anglers, the commercial fishing industry, and the NMFS. The CSTP data describe the geographic range, minimum estimates of longevity, and movements of coastal and pelagic sharks in the Atlantic Ocean using conventional mark/recapture methods. This document summarizes information collected by the CSTP for a 52-year period through 2013, updating a previous 1998 publication. A total of 229,810 sharks of 35 species were tagged, and 13,419 sharks of 31 species were recaptured during this period. To characterize the move- pants fishing for sharks with a variety of gear types. Detailed summary information on the history and methods of the CSTP has been published previously (Casey, 1985; Casey and Kohler, 1992; Kohler et al., 1998; Kohler and Turner, 2001) and excerpts from those reports are included here.

A mark (also defined as tag)/recapture $(\mathrm{M} / \mathrm{R})$ approach to studying sharks is an applied science used by fishery managers to support sustainable management of shark populations (Rounsefell and Everhart, 1953; Harden Jones, 1968; Kohler and Turner, 2001; Speed et al., 2010). This requires knowledge of stock boundaries and spatial ecology within the geographic range of the species in question (Sims, 2010; Queiroz et al., 2016). Tagging data can be used to calculate movement vectors that allow spatially explicit population models (Vandeperre et al., 2014) to delineate life-stage-specific habitats such as pupping or feeding areas. For example, many sharks demonstrate sex-specific dispersal or migratory patterns (Vandeperre et al., 2014; Secor, 2015) or increasing range

ments and distribution patterns, these data were summarized by sex for times at liberty and distance traveled. The longest time at liberty for any individual shark was 27.8 years (sandbar shark). Distances traveled ranged from negligible movement to 3,997 nautical miles (blue shark). Overall, and in some cases, seasonal distributions, as well as movements of tagged sharks, are mapped with respect to the Atlantic Ocean and marginal seas, state boundaries, the 200 mile United States Exclusive Economic Zone, and international and territorial waters of other countries. Detailed profiles are provided for 14 noteworthy shark species where the updated data have significantly extended previous ranges and movements. with body size (Speed et al.; 2010; Secor, 2015). These data have spurred more detailed genomic and electronic tagging studies into adaptive significance and contribute to placement and monitoring of marine reserves or related conservation measures (McCandless et al., 2007; Portnoy et al., 2015). Life history parameters such as age, growth, reproduction, and mortality can be independently estimated from tagging data providing basic inputs into stock assessment models and verification of traditional biological estimates (Brooks et al., 2010). Mark and recapture may be the most costeffective, reliable, and direct means to obtain population data for sharks but there are also specific challenges (Everhart and Youngs, 1981; Gordon, 1990).

The spatial and temporal scales involved with tracking shark movement can be considerable as many shark species are moving long distances over whole ocean basins involving multinational fisheries (Kohler et al., 1998). Other species are difficult to study because they are inaccessible in oceanic or deepwater habitats, while some species are rare or with low population numbers (McLaughlin and O'Gower, 1971). Even seemingly accessible species, such as those in coastal habitats, present issues such as being large, active predators not easily available for any length of time (Kneebone et al., 2012). Due to these limiting factors, information on long distance movements, migratory ranges, and movement patterns is lacking for many shark species (Ferreira et al., 2015). The paucity of information hinders assessments of population trends or spatial management options (Lea 
et al., 2015; Queiroz et al., 2016) at a time when data are needed to gain insight into shark migration pathways, population structure, spatial vulnerability to fisheries, and ecological impacts (Sims, 2010; Campana, 2016). The collaborative CSTP, with volunteers tagging and recapturing throughout the range of many of these species over a long time period, is an effective and efficient approach to address these challenges and meet these conservation and management goals of sustainability.

This report addresses the critical need for information on the movements and distribution patterns of Atlantic shark species, particularly over large spatial and temporal scales. It updates and replaces a previous atlas (Kohler et al., 1998), adding an additional 20 years of CSTP M/R information for coastal and pelagic shark species. Summary statistics on numbers of fish tagged and recaptured, long distance and time at liberty maximums, and seasonal and transboundary movements are tabulated. Additionally, 14 species-specific profiles are included to highlight updates for sharks where new data have extended previous ranges and movements.

\section{Materials and Methods}

Tagging methods have remained consistent during the past 52 years (Kohler et al., 1998; Kohler and Turner, 2001). The two principal tags are a dart tag (M tag) and a fin tag (Rototag) (Fig. 1). The dart tags, in use since 1965, are sent to participants on self-addressed return postcards for recording tagging information (species, size, and sex of shark, date and location of tagging, and gear) along with a tagging needle, tagging instructions, and shark identification and fisheries management information. Fin tags are used primarily by participating biologists. Each $\mathrm{M}$ tag has a capsule with a legend containing contact information and a request for information. Thus, when a tagged shark is re-caught similar data to that collected at tagging is obtained which allows for the calculation of time at liberty, displacement,
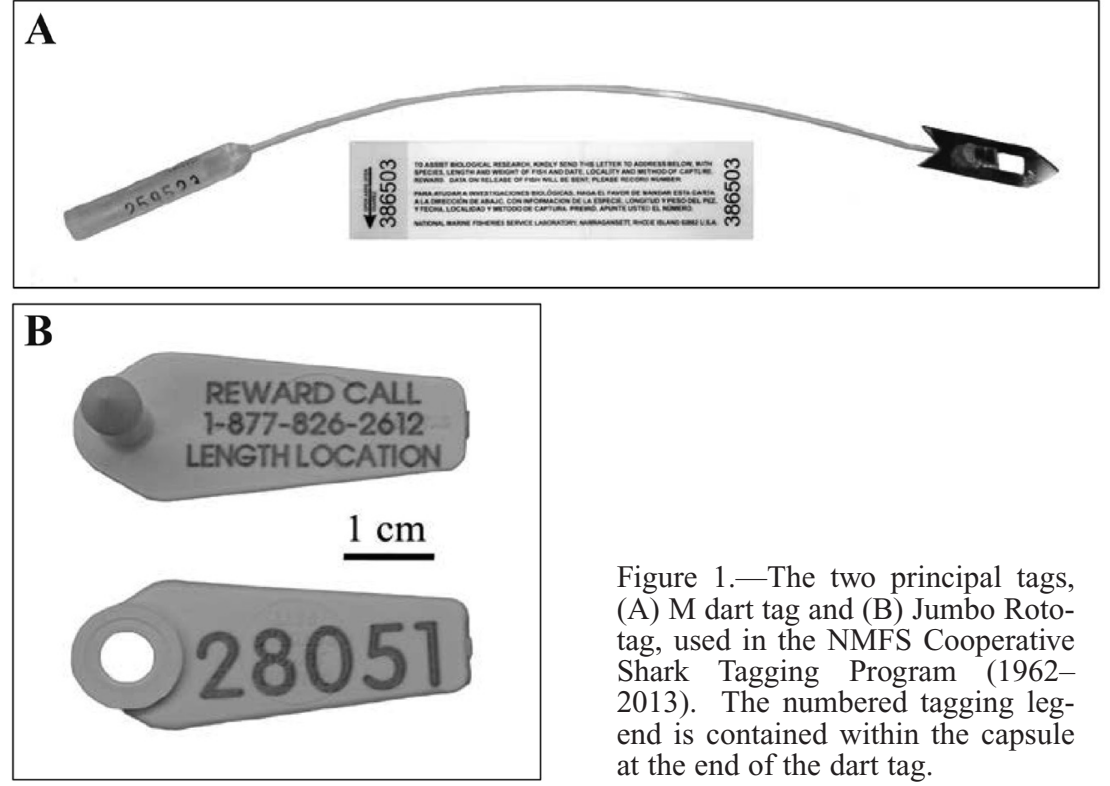

Figure 1.-The two principal tags, (A) M dart tag and (B) Jumbo Rototag, used in the NMFS Cooperative Shark Tagging Program (19622013). The numbered tagging legend is contained within the capsule at the end of the dart tag.

and growth. In 1988, a hat with an embroidered logo replaced the previous monetary reward.

Data quality assurance and quality control (QA/QC) is an ongoing process for the program (Kohler et al., 1998). The CSTP has continued to improve its participants' ability to correctly identify species (SchulzeHaugen et al., 2003), as well as to contact individuals, when possible, on missing or suspect information (e.g., size estimate too small or large based on knowledge of species, and outlier locations on land). Other auditing procedures include rapid follow-up to the person returning the recapture report to verify data, obtaining pictures, and generating distribution maps by species of previous year's $M / R$ data to verify locations.

These efforts have been aided, in particular, by the development of the NMFS Integrated Mark/Recapture Database System (I-MARK), which was brought online in 2008 to provide a platform to keep multi-species tagging program data in a common format for management and analysis. I-MARK is a web application written in PERL scripting language used for data input and quality control of the $\mathrm{M} / \mathrm{R}$ data, which is maintained in an Ora- cle $^{1}$ database. I-MARK was designed to facilitate the tracking of fish (e.g., one fish re-tagged several times with different tags) and tag numbers independently and consists of several web application modules including an inventory of tags, initial release events, subsequent recapture events, bulk data entry of large groups of tags (e.g., from research surveys), contact name and address information, map display, reports, and statistical queries. Fate of the animal, fate of the tag, double tags, and multiple recaptures can be accommodated within the database. Most importantly, the web application provides extensive QA/QC during the entry and maintenance of the I-MARK data; standard audits check data type, outlier locations, and other allowable values such as maximum sizes. More complex validations are also included to check relationships between the fate of animal, the fate of tag, and event type. To provide feedback to the participants, the web application generates a letter that includes a map and information on size, location of tagging and recapture, time at liberty, and distance traveled of each shark that is

${ }^{1}$ Mention of trade names or commercial firms does not imply endorsement by the National Marine Fisheries Service, NOAA. 
Table 1.-Summary of tag and recapture data for 35 species of sharks from the NMFS Cooperative Shark Tagging Program (1962-2013).

\begin{tabular}{|c|c|c|c|c|c|c|}
\hline Common & Scientific & $\begin{array}{c}\text { Number of } \\
\text { sharks tagged }\end{array}$ & $\begin{array}{c}\text { Number of } \\
\text { sharks recaptured }\end{array}$ & $\begin{array}{c}\text { Recapture } \\
\text { rate }(\%)\end{array}$ & $\begin{array}{l}\text { Max. distance } \\
\text { traveled (nmi) }\end{array}$ & $\begin{array}{l}\text { Max. time } \\
\text { at liberty (yr) }\end{array}$ \\
\hline Atlantic angel shark & Squatina dumeril & 170 & 0 & 0.0 & - & - \\
\hline Atlantic sharpnose shark & Rhizoprionodon terraenovae & 4,977 & 79 & 1.6 & 570 & 7.3 \\
\hline Basking shark & Cetorhinus maximus & 168 & 0 & 0.0 & - & - \\
\hline Bigeye thresher & Alopias superciliosus & 400 & 12 & 3.0 & 2,067 & 10.5 \\
\hline Bignose shark & Carcharhinus altimus & 175 & 11 & 6.3 & 1,778 & 11.2 \\
\hline Blacknose shark & Carcharhinus acronotus & 2,958 & 35 & 1.2 & 226 & 9.9 \\
\hline Blacktip shark & Carcharhinus limbatus & 10,293 & 269 & 2.6 & 1,183 & 9.3 \\
\hline Blue shark & Prionace glauca & 117,962 & 8,213 & 7.0 & 3,997 & 15.9 \\
\hline Bonnethead & Sphyrna tiburo & 5,057 & 221 & 4.4 & 302 & 7.0 \\
\hline Bull shark & Carcharhinus leucas & 2,129 & 36 & 1.7 & 628 & 6.7 \\
\hline Common thresher shark & Alopias vulpinus & 203 & 4 & 2.0 & 271 & 8.0 \\
\hline Crocodile shark & Pseudocarcharias kamoharai & 20 & 0 & 0.0 & - & - \\
\hline Dusky shark & Carcharhinus obscurus & 8,465 & 164 & 1.9 & 2,052 & 16.1 \\
\hline Finetooth shark & Carcharhinus isodon & 2,807 & 60 & 2.1 & 365 & 4.9 \\
\hline Galapagos shark & Carcharhinus galapagensis & 422 & 18 & 4.3 & 1,087 & 7.1 \\
\hline Great hammerhead & Sphyrna mokarran & 282 & 5 & 1.8 & 649 & 3.4 \\
\hline Greenland shark & Somniosus microcephalus & 68 & 1 & 1.5 & 0 & 1.0 \\
\hline Lemon shark & Negaprion brevirostris & 3,231 & 277 & 8.6 & 494 & 10.9 \\
\hline Longfin mako & Isurus paucus & 106 & 6 & 5.7 & 1,852 & 5.5 \\
\hline Night shark & Carcharhinus signatus & 289 & 19 & 6.6 & 1,456 & 13.8 \\
\hline Nurse shark & Ginglymostoma cirratum & 2,186 & 175 & 8.0 & 385 & 11.6 \\
\hline Oceanic whitetip shark & Carcharhinus longimanus & 643 & 8 & 1.2 & 1,226 & 3.3 \\
\hline Porbeagle & Lamna nasus & 1,754 & 178 & 10.1 & 1,216 & 16.8 \\
\hline Reef shark & Carcharhinus perezii & 768 & 24 & 3.1 & 26 & 9.2 \\
\hline Sand tiger & Carcharias taurus & 2,019 & 73 & 3.6 & 641 & 5.3 \\
\hline Sandbar shark & Carcharhinus plumbeus & 35,929 & 1,474 & 4.1 & 2,039 & 27.8 \\
\hline Scalloped hammerhead & Sphyrna lewini & 3,537 & 62 & 1.8 & 902 & 9.6 \\
\hline Shortfin mako & Isurus oxyrinchus & 8,525 & 1,148 & 13.5 & 3,043 & 12.8 \\
\hline Silky shark & Carcharhinus falciformis & 1,238 & 65 & 5.3 & 1,288 & 8.6 \\
\hline Smalltail shark & Carcharhinus porosus & 24 & 0 & 0.0 & - & - \\
\hline Smooth dogfish & Mustelus canis & 1,186 & 37 & 3.1 & 460 & 6.8 \\
\hline Smooth hammerhead & Sphyrna zygaena & 269 & 7 & 2.6 & 496 & 2.1 \\
\hline Spinner shark & Carcharhinus brevipinna & 1,723 & 27 & 1.6 & 861 & 6.8 \\
\hline Tiger shark & Galeocerdo cuvier & 9,772 & 709 & 7.3 & 3,643 & 11.2 \\
\hline White shark & Carcharodon carcharias & 55 & 2 & 3.6 & 546 & 2.5 \\
\hline
\end{tabular}

then sent to both the tagger and recapturer along with the reward.

Data for this atlas are for sharks that were tagged and/or recaptured between 1962 and 2013 in the Atlantic Ocean (North and South) and its marginal and associated seas, including the Gulf of Mexico, Caribbean Sea, and Mediterranean Sea. Only those tags or recaptures with year and location information were included for analysis. A recapture was excluded if a tagged shark was found dead (e.g., on a beach) or if only the tag was found. In addition, sharks released from aquaria and embryos were omitted from the database; these types of releases may artificially indicate species presence outside of their normal distribution. Distance traveled is the great circle distance in nautical miles (nmi) between tag and recapture locations for a single event. For species (e.g., sandbar shark) that traveled between the Atlantic and Gulf of Mexico, the great circle distance would cross land through Florida, a significant underestimate, so the routes be- tween mark and recapture for these fish were assumed to pass through two standard offshore waypoints, southeast and southwest of Florida (bordering the Straits of Florida).

Cooperative Shark Tagging Program $\mathrm{M} / \mathrm{R}$ data for sharks are displayed by species in a two-page format with standard sets of figures (maps and graphs). For ease in locating data displays, species sections appear in alphabetical order by common name which are used throughout the text (see Table 1 for scientific names). Maps are displayed in a longitude/latitude WGS 84 projection with the United States (U.S.) Exclusive Economic Zone (EEZ) boundary represented by a dotted-dashed line and 200 meter (m) contour by a solid line. Latitude and longitude grids are in $10^{\circ}$ increments for all maps. Data for each species are presented in similar format. Overall summary information is presented as total and by sex and includes numbers that were tagged and recaptured, recapture percentage, mean and maximum distance traveled (nmi), and time at liberty (years). Yearly summaries include the number of sharks tagged and recaptured and percent recapture plotted on three distinct line graphs with the same year scale for comparison. Percent recapture was calculated as the number of sharks subsequently recaptured from a particular release year divided by the number of sharks tagged that year. Maps include

1) Recapture distribution where $M / R$ information for each species is displayed on a single map, and only those data with both mark and recapture locations were displayed. For distances traveled greater than or equal to $10 \mathrm{nmi}$, arrows depict the point of tagging (origin of arrow) and point of recapture (arrow head). For distances traveled less than $10 \mathrm{nmi}$, recaptures are distinguished by a triangle.

2) Distribution locations by sex where all tag and recapture locations of an individually marked 


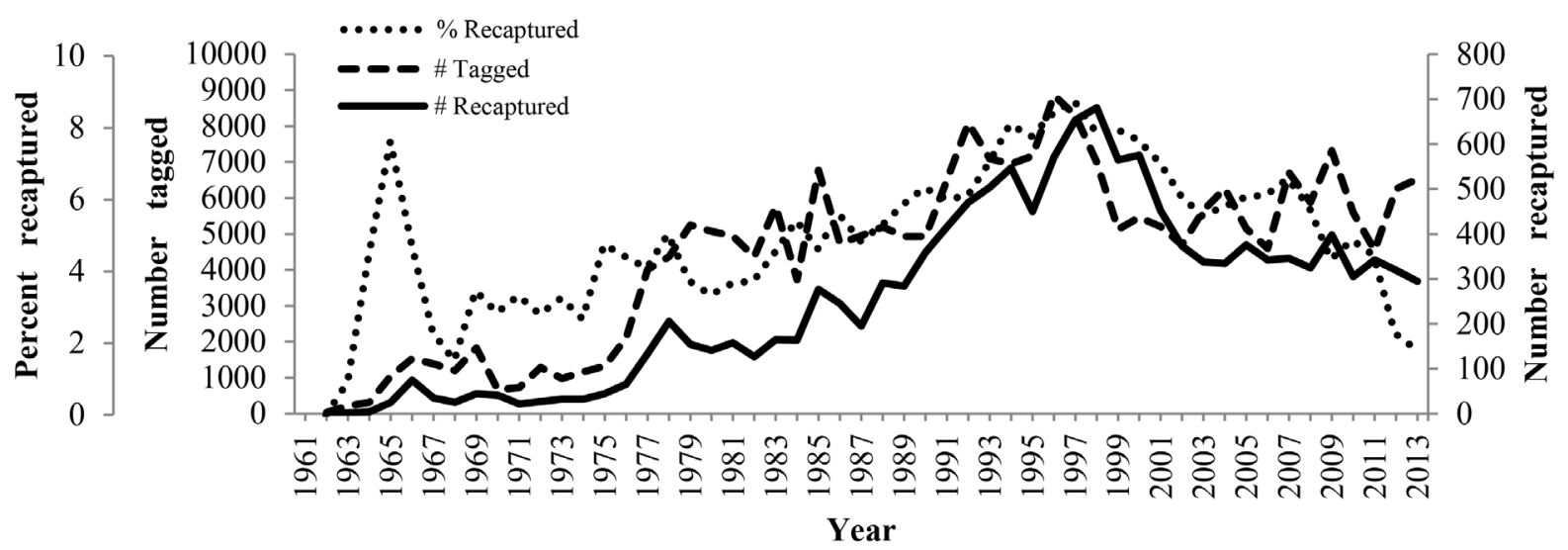

Figure 2.- Yearly summary of number of sharks tagged, recaptured, and percent recapture rate for all sharks in the NMFS Cooperative Shark Tagging Program (1962-2013).

fish are plotted to show the total distribution of a species in a geographic area. On some maps, an inset was included (e.g., blacktip shark) to increase clarity for the majority of the data.

3) Seasonal distribution of the western North Atlantic M/R locations during spring (March, April, May), summer (June, July, August), fall (September, October, November), and winter (December, January, February). To clarify and facilitate comparisons among seasons, only the western North Atlantic M/R locations were displayed on the same map scale for each season. For species where no western North Atlantic data exist (e.g., crocodile shark), all data were displayed by season. An additional two-page layout was added for species with large numbers of tags and recaptures (blue shark) and/or extensive geographic ranges (blue shark, shortfin mako, tiger shark).

\section{Results and Discussion}

\section{Totals}

Between 1962 and 2013, a total of 229,810 sharks of 35 species were tagged and 13,419 sharks of 31 species were recaptured (Table 1, Fig. 2).

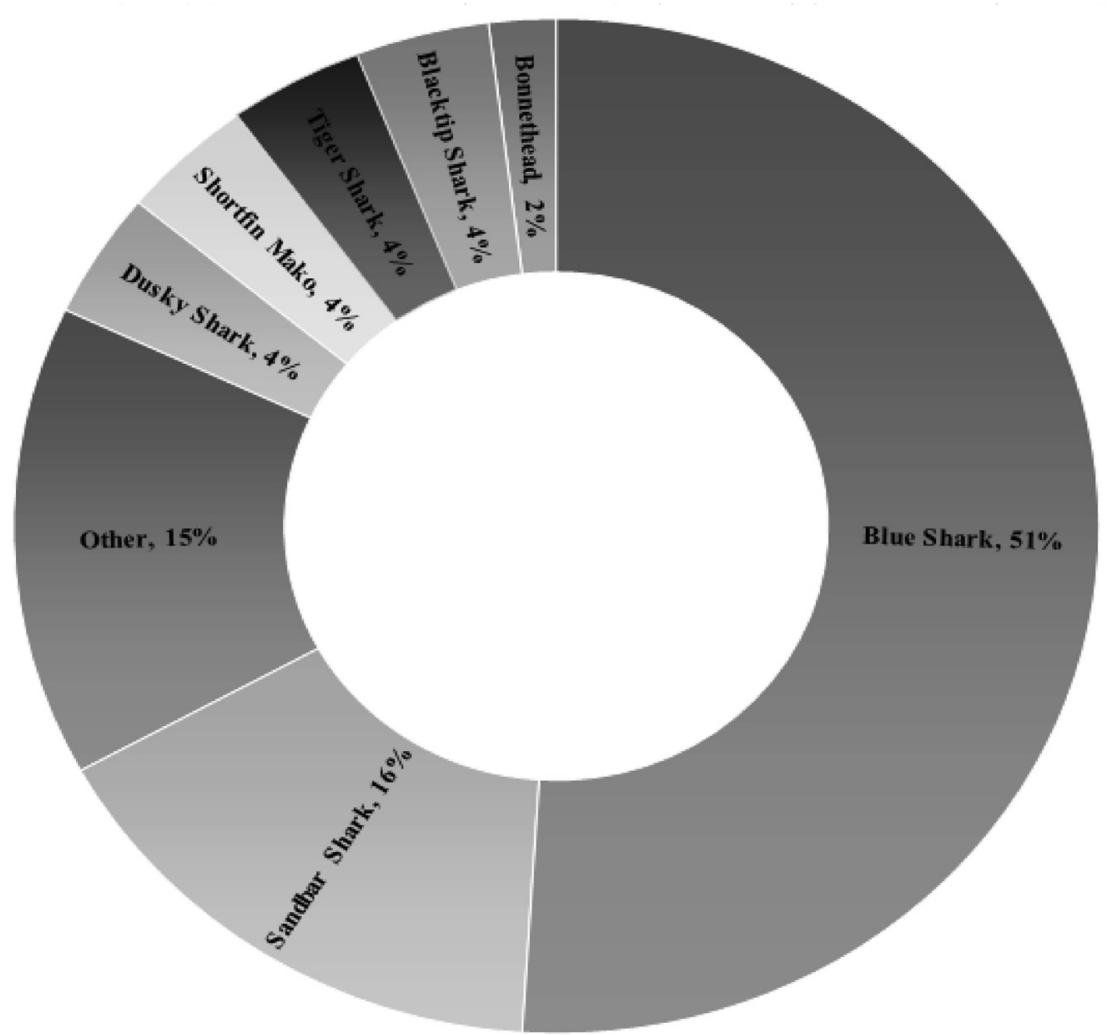

Figure 3.- Summary of tag releases by species in the NMFS Cooperative Shark Tagging Program (1962-2013).

Fishermen representing 32 countries have tagged sharks for the CSTP and 59 countries are represented in the tag returns. Seven species accounted for $85 \%$ of the tags, and a single species, the blue shark, accounted for 51\% of the total tagged sharks (Table 1,
Fig. 3). The number of sharks tagged ranged from 20 for the crocodile shark to 117,962 for the blue shark. Most species (31) had more than 100 sharks tagged.

Numbers of tag returns by species ranged from 0 to 8,213 . Seven species 
accounted for $91 \%$ of the recaptures, and the blue shark accounted for $61 \%$ of the recaptured sharks (Table 1, Fig. 4). For most species (25), less than 100 fish were recaptured. The recapture rate ranged from $0.0 \%$ (Atlantic angel shark, basking shark, crocodile shark, and smalltail shark) to $13.5 \%$ (shortfin mako) with an overall mean of $5.8 \%$.

Overall, recreational fishermen $(56 \%)$, most using rod and reel, accomplished the majority of the tagging (Fig. 5) followed by biologists $(32 \%)$ using longline and net gear. The majority of tag returns were from commercial fishermen (50\%) using longline and net gear and anglers (43\%) using rod and reel (Fig. 6).

\section{Times at Liberty}

With the inclusion of the additional 20 years of CSTP data since Kohler et al. (1998), time at liberty has increased substantially for 22 species. These increases ranged from months (e.g., blacknose shark, dusky shark, night shark, tiger shark) to many years (e.g., blue shark, bonnethead, lemon shark, porbeagle, spinner shark) (Table 1). The longest time at liberty for any individual shark remained at 27.8 years. This record is for a sandbar shark that was tagged by Narragansett NMFS biologist Charles Stillwell, fishing with a gill net in Great Machipongo Sound, VA, in June of 1965, and recaptured by a commercial shark longline fisherman east of Daytona Beach, FL, in March of 1993. Overall, individuals of 11 species were at liberty for more than 10 years, 14 were at liberty between 5-10 years, and 6 for less than 5 years. Most recaptured sharks were at liberty for less than 1 year $(59 \%)$ and from 1 to 5 years (36\%) (Fig. 7).

Knowledge of longevity estimates is needed for calculation of lifetime fecundity, which is especially critical for long lived, slow growing animals, such as sharks. Longevity can be estimated using the oldest aged specimen in a traditional hardpart ageing study (minimum estimate), calculations from von Bertalanffy growth function parameter estimates (e.g., $L_{\infty}$ ), or using radiocar-

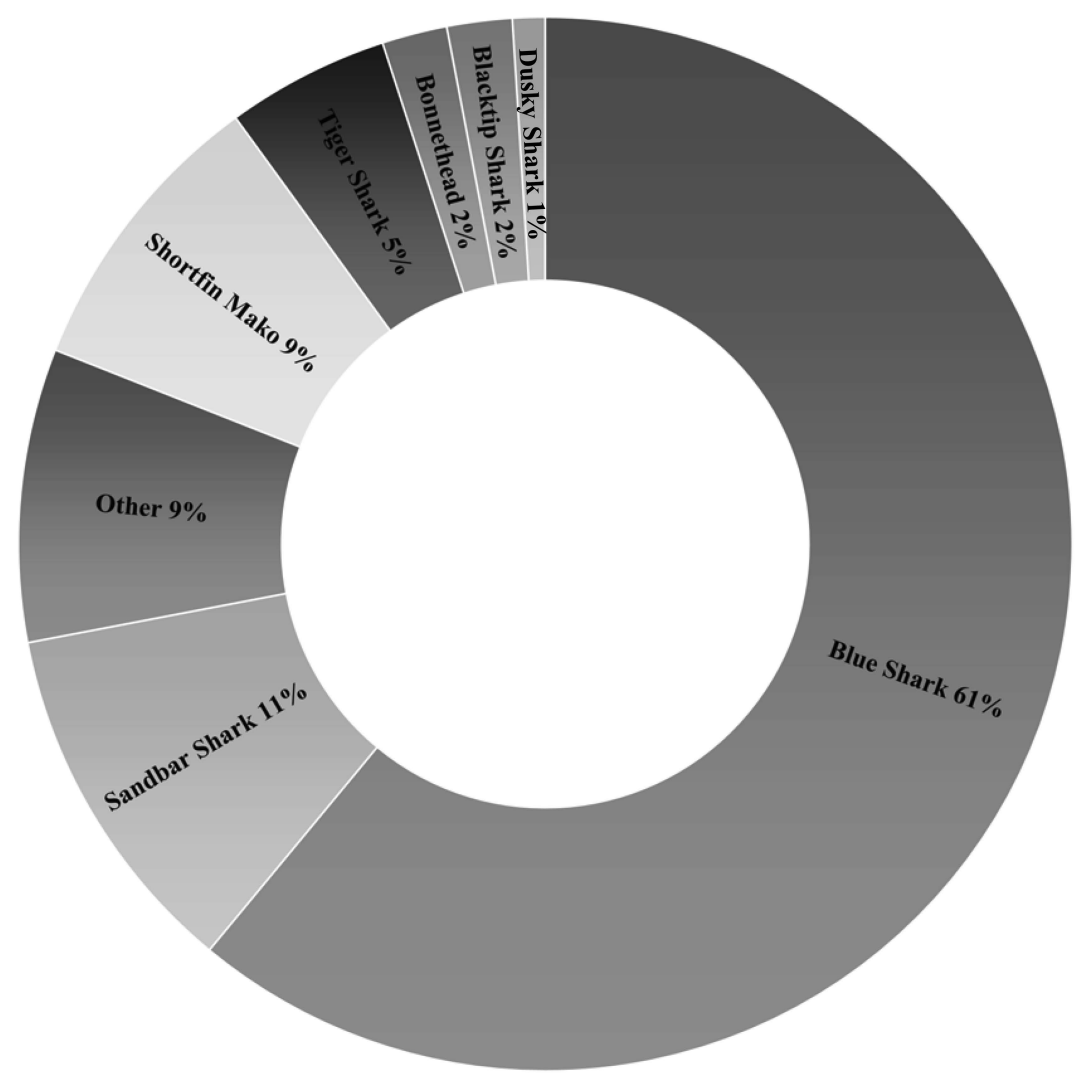

Figure 4.- Summary of tag returns (recaptures) by species in the NMFS Cooperative Shark Tagging Program (1962-2013).

bon dating in combination with band pair counts (Natanson et al., 2002; Andrews et al., 2011). Maximum time at liberty records from $\mathrm{M} / \mathrm{R}$ data serve as direct evidence of longevity, particularly if size (age) at tagging is taken into account (Casey and Natanson 1992; Frazier et al., 2015). Times at liberty verify calculated data for certain species (e.g., shortfin mako, blue shark, sandbar shark), or serve as a proxy for minimum lifespan estimates for species with no published age data.

Longevity estimates for shortfin mako based on analyses of vertebral centra ranged from 21 to 38 years, for males and females, respectively $(\mathrm{Na}-$ tanson et al., 2006). Long-term recaptures reported in Natanson et al. (2006), include a male at liberty for 12.8 years (estimated age at recapture, based on length at tagging, was 21 years) and a female at liberty for
10.5 years (estimate age at recapture was 32 years). In 2015, a male shortfin mako (not included in this analysis) that was tagged as a 1+ years was recaptured after 19.1 years at liberty. This recapture also verifies a $20+$ year longevity for the species. It is notable that this fish was recaptured only 55 nmi from its original tagging location.

The oldest directly aged blue shark was 16 and 15 years for males and females, respectively, in a validated age study of blue sharks in the North Atlantic Ocean (Skomal and Natanson, 2003). Calculated longevities from that study based on $95 \%$ and $99 \%$ of $\mathrm{L}_{\infty}$ ranged from 16.5-26.1 years (Skomal and Natanson, 2003). The longest time at liberty for a blue shark in the CSTP is 15.9 years (Table 1). Based on provided estimates of length and weight, this male blue shark was 8-11 years of age at tagging and thus 

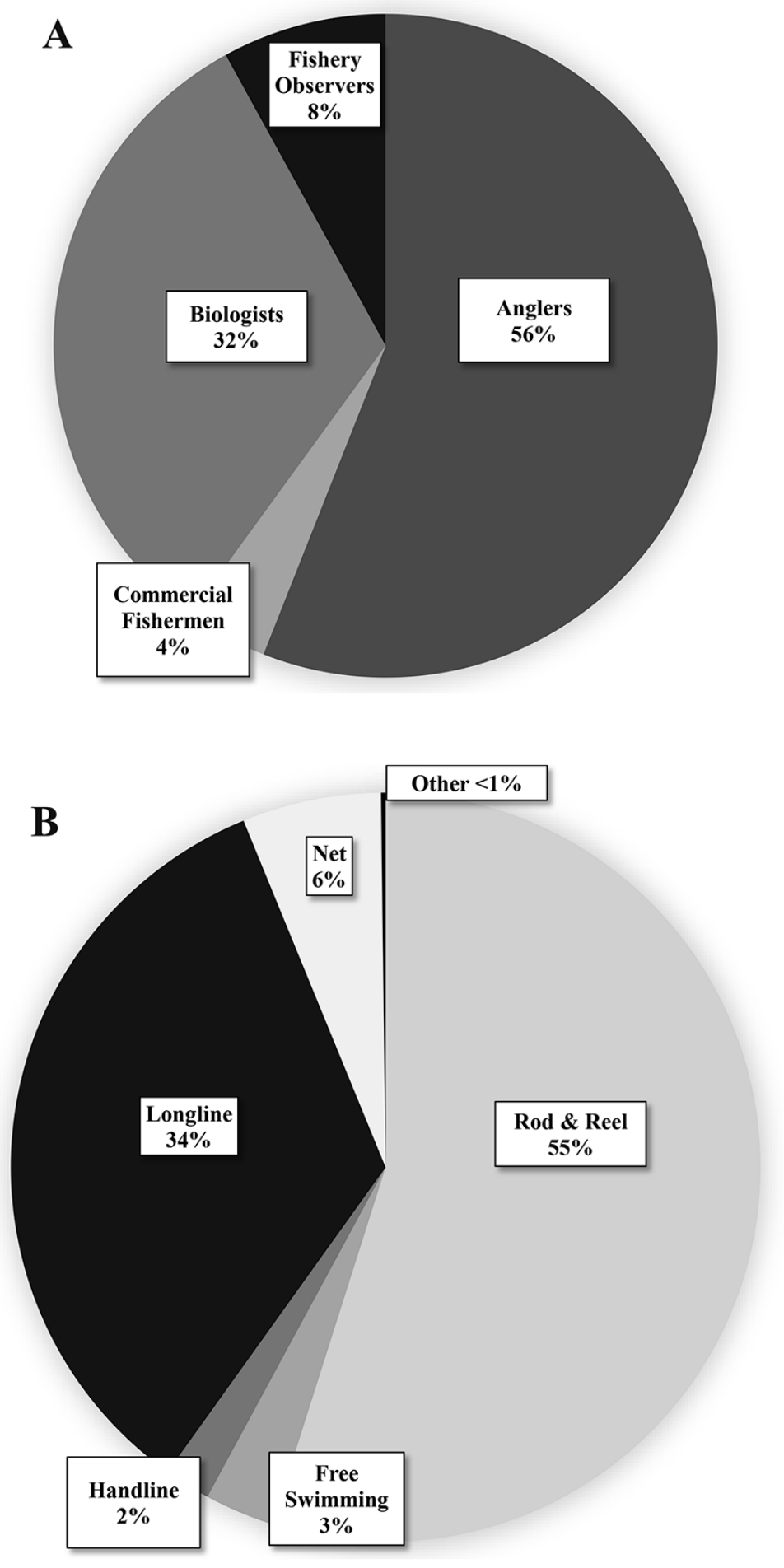

Figure 5.- Summary of tag releases by (A) industry of participants and (B) gear in the NMFS Cooperative Shark Tagging Program (1962-2013). would have been between $24+$ and $27+$ years at recapture; verifying and possibly extending the published longevities for this species.

As noted previously, the overall CSTP maximum time at liberty record is for a sandbar shark at large for 27.8 years (Table 1). Age at recapture for this fish was estimated at 33 to 36 years which confirms the $30+$ years reported from growth bands in vertebrae and bomb radiocarbon dating (Andrews et al., 2011).

\section{Distances Traveled}

Distances traveled ranged from negligible movement to 3,997 nmi (blue shark) (Table 1). Two peaks in distance traveled were observed: one at less than 100 miles (46\%) and the second between 1,000 to $2,000 \mathrm{nmi}(17 \%)$ (Fig. 8). Maximum distance traveled reflects the longest distance between mark and recapture for a single event (Table 1). Since Kohler et al. (1998), maximum distances traveled increased for 20 species between $10 \mathrm{nmi}$ (reef shark) to $1,700 \mathrm{nmi}$ (tiger shark) (Table 1). Overall, individuals of three species traveled distances greater than 3,000 nmi (blue shark, shortfin mako, tiger shark); three species traveled distances between 2,000-3,000 nmi (bigeye thresher, dusky shark, sandbar shark), and eight species traveled between 1,000-2,000 miles (bignose shark, blacktip shark, Galapagos shark, longfin mako, night shark, oceanic whitetip shark, porbeagle, and silky shark). Individuals of seven species traveled distances between 5001,000 nmi (Atlantic sharpnose shark, bull shark, great hammerhead, sand tiger, scalloped hammerhead, spinner shark, and white shark).

In some instances, a shark may be recovered multiple times after the initial tagging and is subsequently released with the original tag in place or retagged with a new tag. For these fish, the total distance traveled may be larger than the furthest for a single tagging event (maximum distance travelled) as is the case for both the nurse shark (385 $\mathrm{nmi}$ to $387 \mathrm{nmi}$ ) and sand tiger (641 nmi to $755 \mathrm{nmi}$ ). A nurse shark 
was originally tagged near Bimini, Bahamas, and recaptured in the same area (2 nmi) 2.7 years later; a second recapture occurred off Cuba (385 nmi from the first recapture location) after 2.3 years. A sand tiger was recaptured three times and was at liberty for nearly 3 years. The fish was originally tagged off the coast of Maryland in early fall of 2009. Its first recapture was to the north, off Delaware, in late summer of 2010 (20 $\mathrm{nmi})$; it was again recaptured to the south, off South Carolina, in late spring of 2011 (364 nmi from the first recapture location); and its third recapture was again to the north, off Delaware, in late summer of $2012(371 \mathrm{nmi}$ from the second recapture location). Details of these multiple recaptures over time also highlight a north-south seasonal component to the migrations of this species.

\section{Transboundary Movements}

Sharks can be highly mobile, moving long distances often over entire ocean basins. Detailing these movements with respect to national and international boundaries is critical for the sustainable management of shark populations. Overall, 22 species crossed the U.S. EEZ boundary (Table 2). Twenty-seven species occurred in the Gulf of Mexico. Thirteen species moved into the Gulf of Mexico from the Atlantic and 11 species moved out of the Gulf of Mexico into the Atlantic. Twenty species occurred in the Caribbean Sea. Ten moved into the Caribbean Sea from the Atlantic Ocean; one moved in from the Gulf of Mexico (tiger shark), and one was recaptured at the entrance of the Caribbean Sea from the Gulf of Mexico (dusky shark). Two species (blue shark, tiger shark) were tagged in the Caribbean Sea and moved to the Atlantic Ocean. Ten species occurred in the South Atlantic, and one species, the blue shark, crossed the equator from the North Atlantic Ocean to the South Atlantic Ocean (Table 2).

\section{Seasonal Distribution}

Seasonal migrations are common in many animal taxa and can be defined
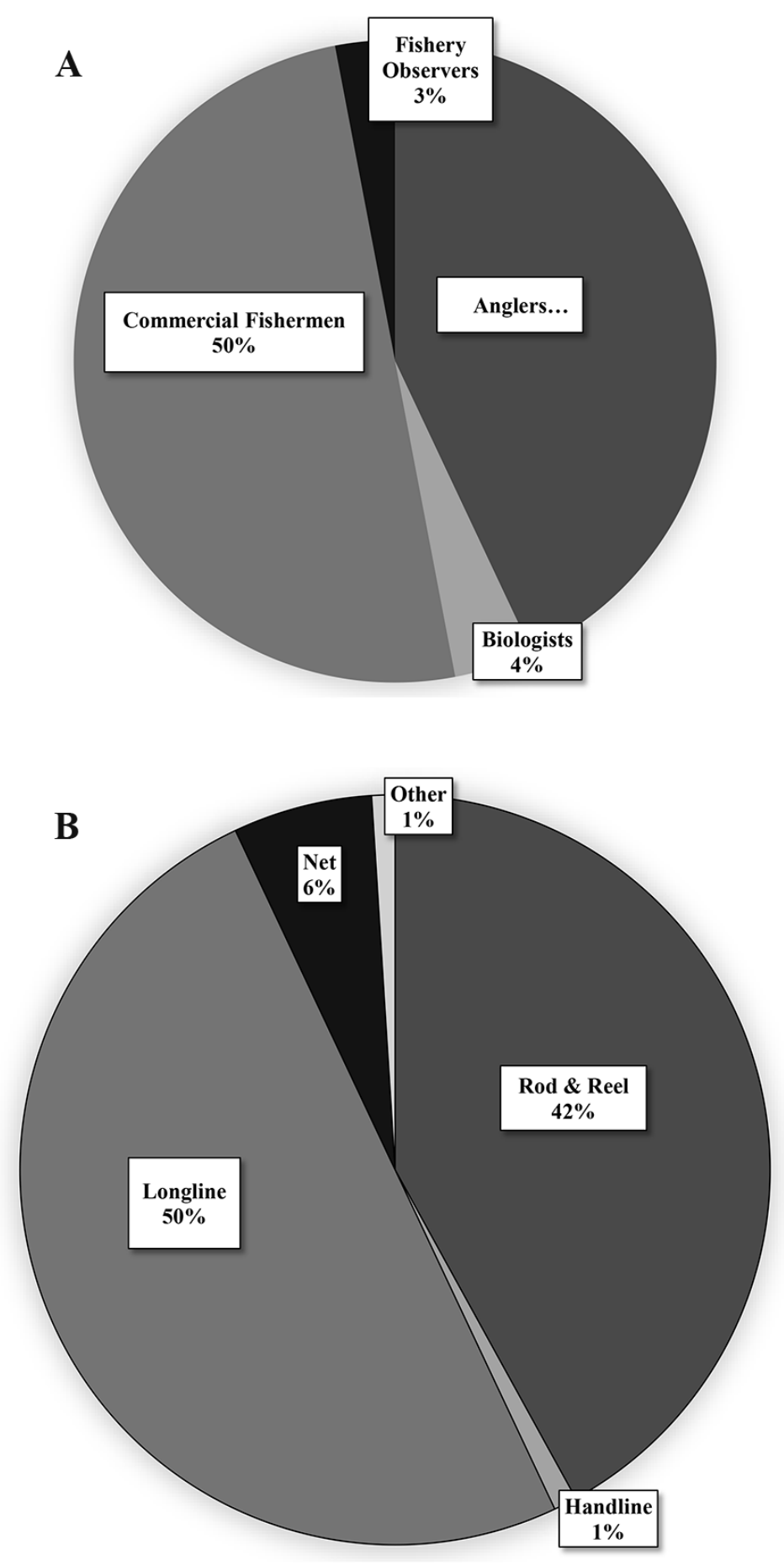

Figure 6.-Summary of tag returns (recaptures) by (A) industry of participants and (B) gear in the NMFS Cooperative Shark Tagging Program (1962-2013). 


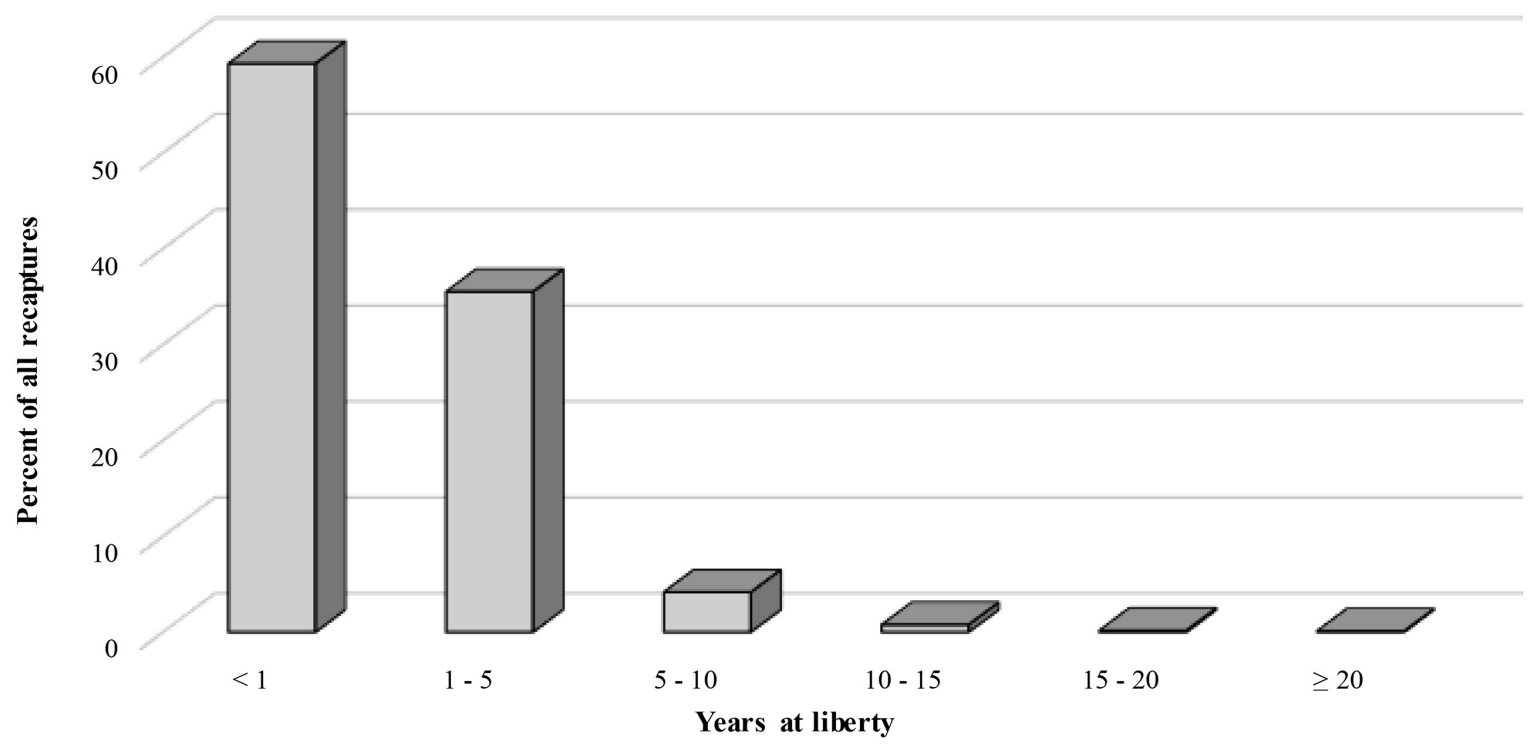

Figure 7.- Times at liberty for all tag returns in the NMFS Cooperative Shark Tagging Program (1962-2013).

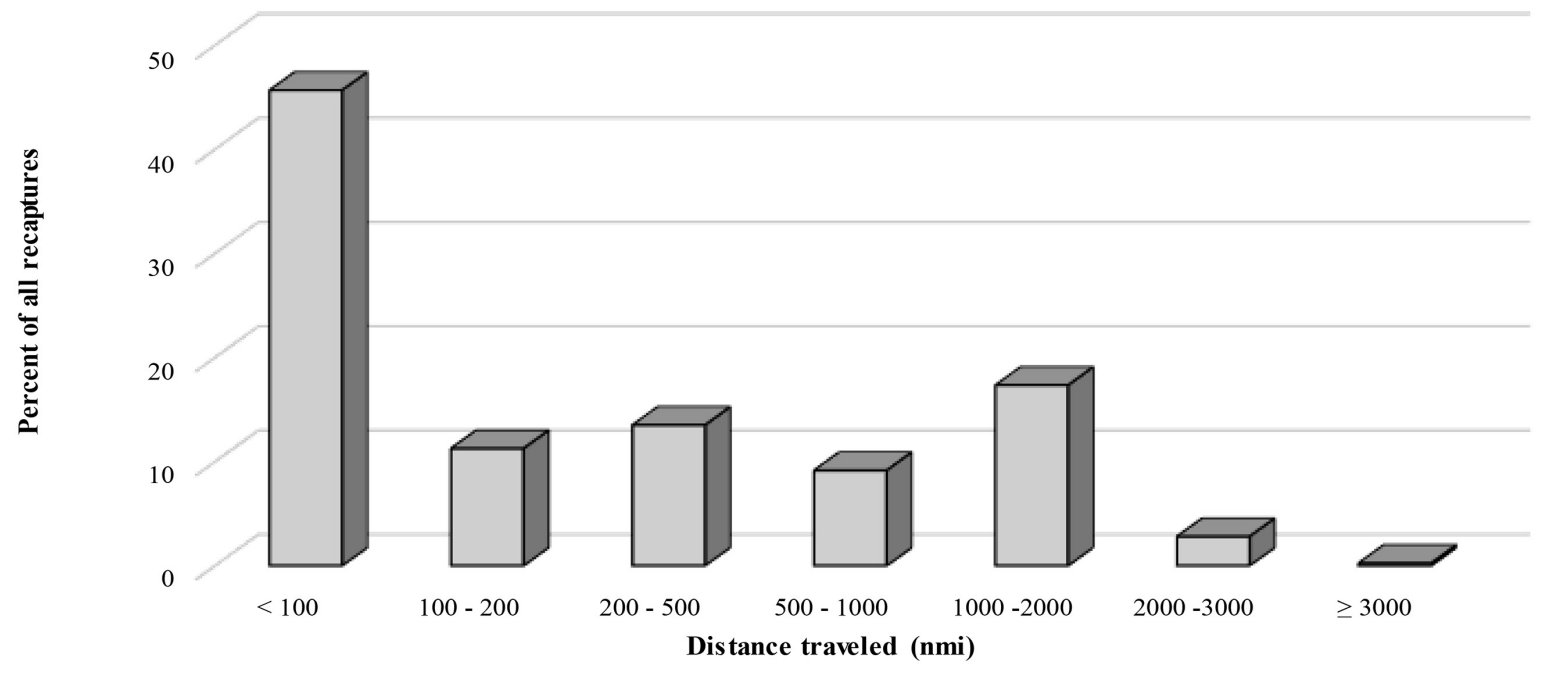

Figure 8.-Distances traveled by sharks tagged and recaptured in the NMFS Cooperative Shark Tagging Program (1962-2013).

as movements between distinct habitats where organisms take advantage of available resources at each location to enhance fitness (Ramenofsky and Wingfield, 2007). Sharks, like most marine species, exhibit distinct thermal preferences (Casey and Kohler,
1992) so shifts in the distribution of species within the North Atlantic can be expected with seasonal changes in water temperature. Many of the species in the CSTP (e.g., Atlantic sharpnose shark, blacknose shark, bull shark, finetooth shark) are at their most north- erly range in summer and fall and are located further south in the colder months of winter and spring. These species are present on the U.S. mid-Atlantic and northeast continental shelf (north of Cape Hatteras, NC) during the warmest months of the year. Some 
Table 2.-Summary of occurrence and transboundary movement for 35 species of sharks from the NMFS Cooperative Shark Tagging Program (1962-2013).

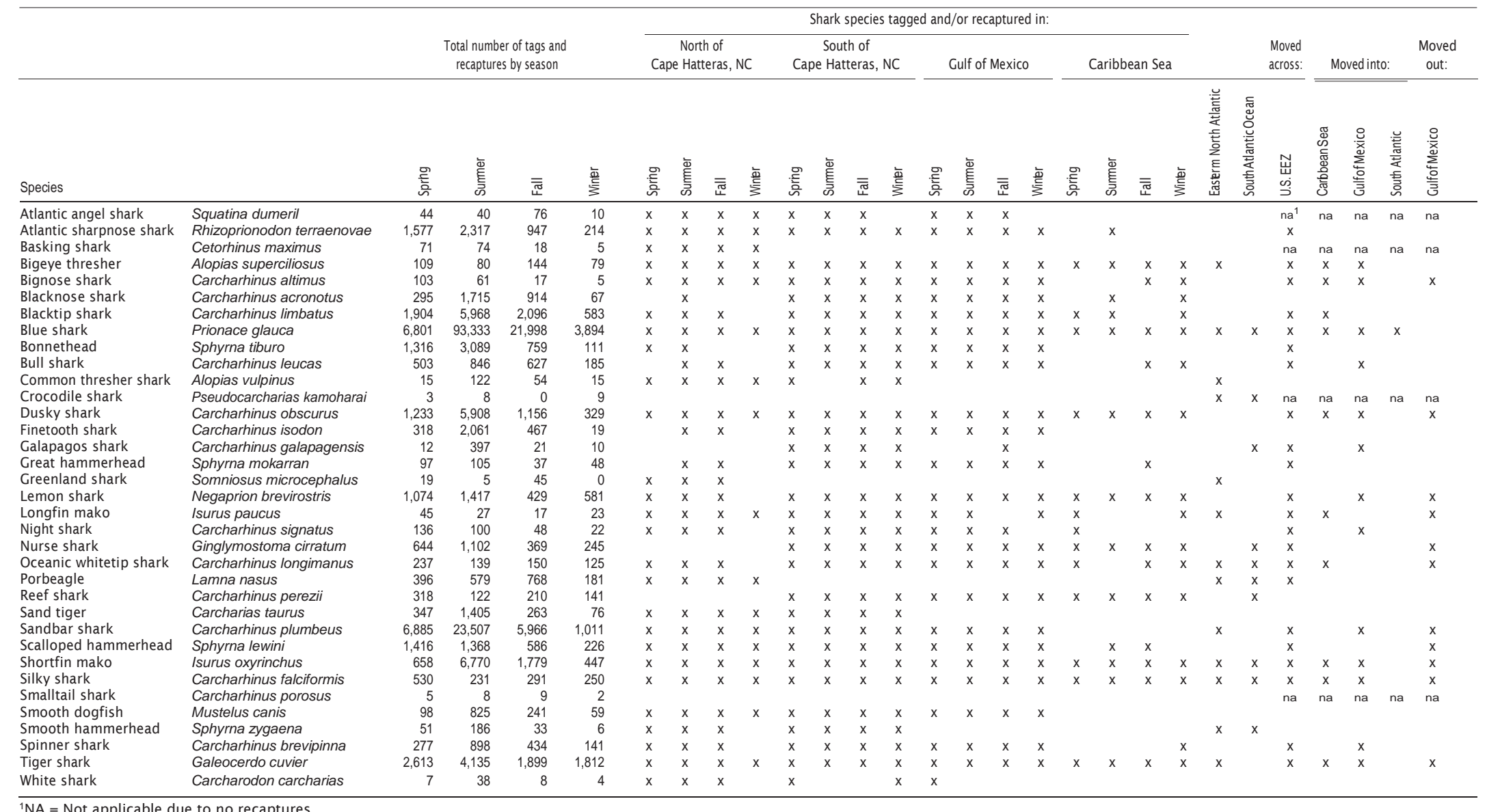

${ }^{1} \mathrm{NA}=$ Not applicable due to no recaptures. 
species (e.g., tiger shark, dusky shark, shortfin mako, and blue shark) also occur in the adjacent shelf edge and oceanic waters, while others mainly occur in the waters of the deeper slope areas and canyons (e.g., night shark) or in oceanic waters (e.g., oceanic whitetip shark). With the exception of five species (crocodile shark, Galapagos shark, nurse shark, reef shark, and smalltail shark), all shark species were found north of Cape Hatteras, NC, in the warmer summer months; these five species are not found or do not generally range this far north along the U.S. East Coast.

Movement patterns seen in the CSTP database include latitudinal and inshore-offshore migrations in response to changing water temperatures and such movements have been shown for almost all families of tagged sharks, e.g., heterodontids (McLaughlin and O'Gower, 1971), lamnids (Bruce, 1992; Casey and Kohler, 1992), carcharhinids (Stevens, 1976; Tricas, 1977; Olsen, 1984; Francis, 1988), sphyrnids (Clarke, 1971), and squalids (Holland, 1957; Jensen et al., 1961; Templeman, 1976). Monthly variations in water temperatures, changes in the path of the Gulf Stream, and the presence of variable oceanic features (e.g., warm and cold core rings, thermal fronts) can, therefore, alter the seasonal distribution of species from year to year.

\section{Data Interpretation Challenges}

The shark distributions presented here from the CSTP database (Table 2, Fig. 9-43) are based on presenceabsence data and thus the number of species during any season can be considered a minimum. There are many reasons why a few individuals of a species are tagged. Some species are naturally uncommon or rare throughout their range (e.g., white shark, longfin mako) and, therefore, a low catch rate would be expected. Other sharks may inhabit areas outside of the principal fishing and tagging effort (e.g., oceanic whitetip shark) and/or may not be present during the primary fishing season. Some may be difficult to iden- tify (e.g., bignose shark), are not readily caught (e.g., basking shark, whale shark), or commonly tagged (e.g., smooth dogfish) by members of the program. Some of the smaller species, such as Atlantic sharpnose sharks, spiny dogfish, and smoothhounds are so numerous that only a small percentage are tagged relative to the number caught, particularly since we discourage use of our tags on sharks less than 3 feet. For these species, the residence times and seasonal distributions are not well characterized by the CSTP data. In addition, fishing effort in some seasons may be low (e.g., winter, spring) or some species may not be selected by the fishing gears active in particular areas/seasons. The data, therefore, may under-represent the species present during those months. A prime example exists for the blue shark in the Northeast U.S., which is the main tagging area for this species. The weather limits fishing in winter, thus the season is primarily May through November; outside this fishing season, total tag numbers may be low due to reduced tagging effort.

The number of fish tagged and recaptured is influenced by many factors and does not directly reflect population abundance or correlate with population trends. For example, tagging effort can vary due to annual changes in fishing effort, weather conditions, water temperature, number of participants in the CSTP, occurrence of research cruises, opening or closure of a commercial fishery, and number of tags available. All these variables are difficult to measure and may mask any direct correlation of number of tags used per year and population size fluctuations. Specifically, the blue shark, is an abundant species and because of its low economic value, many are tagged and released; while the shortfin mako is prized by both recreational and commercial fishermen, tagged and released in relatively low number, and yet has the highest overall percent recapture. Life history characteristics may also influence tagging and recapture probability, e.g., a species that stays in an accessible area for extensive periods of time. For example, the nurse shark, is more subject to capture and recapture than a species that is highly migratory. Some species live in deeper waters or farther offshore and are not present in areas during the primary fishing season, or are simply not readily caught. For instance, 168 basking sharks were tagged by members of the CSTP, but none have been recaptured. This is because basking sharks are relatively easy to tag while they are free swimming but are not often caught on fishing gear and are not subject to directed commercial or recreational fisheries.

Another data interpretation challenge for the CSTP is the lack of information on tag reporting rates, which can be critical to estimating abundance, survival, and exploitation from a tagging program (Pine et al., 2003). There are several methods used to estimate reporting rates including the use of high reward tags and planting tags in specific fisheries (reviewed in Pollock et al., 2001). The CSTP has not conducted any studies to date to estimate reporting rate by species or tag type, however, the future use of a high reward tag should be examined.

The CSTP spans more than 50 years and thus reported shark distributions may represent historic ranges and distributions for some species. Alternatively, range expansions may be associated with environmental change (e.g., water temperature), expanding populations, or movement into new areas to exploit a food supply. Perceived range changes may be due to increased tagging by a user group, increased tagging in a particular area, and/or increased access to a species or species life stage. An example of this is the expansion of the NMFS Cooperative Atlantic States Pupping and Nursery (COASTSPAN) program, which has substantively increased the tagging effort by biologists in coastal areas of the Atlantic states used as pupping and nursery grounds for coastal shark species. The expanded COASTSPAN program has produced substantially more $\mathrm{M} / \mathrm{R}$ data for the Atlantic sharpnose 
shark, blacknose shark, bonnethead, finetooth shark, sand tiger, smooth dogfish, and sandbar shark. In the early years of the CSTP, many of the sharks tagged in the southeastern U.S. were from shore; fishing clubs such as the Florida Shark Club accounted for much of the recreational tagging off Florida. There has been a recent resurgence of shore-based recreational shark fishing in the southeastern U.S. and an expansion into the northeastern U.S. and more blacktip shark, bull shark, lemon shark, and other nearshore species are being tagged as a result of this increased shore-based fishing effort.

The long-term data generated by the CSTP have shown that it is vital to have a large database to determine the movements of sharks. Just since the publication of Kohler et al. (1998), the increased numbers of sharks crossing various boundaries and shark species that have shown differences in movements show the importance having large numbers of each species tagged. For example, until the CSTP was in its 34th year, no known tiger shark had crossed the Atlantic. Using a small short-term subsample would likely bias the data; only conventional tagging can provide the data reported in this study. However, these types of tags do have limitations. Conventional tagging relies on the physical recapture of a shark and location data are only taken at tagging and recapture. Additionally, no environmental or behavioral data are recorded. While satellite tags also have drawbacks (e.g., limited battery life, expense, and up to $60 \mathrm{nmi}$ error in location data), supplementing the conventional tag data with electronic tagging methods, such as popup satellite archival tags and acoustic tag methods, can provide details unavailable to conventional tagging. By combining the larger database of conventional tagging, with the details of the electronic tags, we can fill the spatiotemporal gaps in conventional tag data and add environmental details obtained from electronic tagging to determine not only where the sharks are going but how and why.

\section{Synopses for Selected Species}

With the addition of 20 years of $\mathrm{M} / \mathrm{R}$ data (over 123,000 sharks tagged and 8,000 sharks recaptured) to the CSTP since the previous atlas (Kohler et al., 1998), new information has extended, in some cases, species ranges and distributions farther north and south and illustrated more transboundary movements and migrations into specific bodies of water (Table 2; Fig. 9-43). In addition, $\mathrm{M} / \mathrm{R}$ information was included for two additional species of shark (crocodile shark, smooth dogfish). Selected species-specific profiles are included to highlight noteworthy updates for sharks where new data have extended previous ranges and movements.

\section{Bigeye Thresher}

The bigeye thresher is reported as an oceanic and coastal species, virtually circumglobal in tropical and temperate seas (Castro, 2011). In the Atlantic, they are distributed from Cape Cod (Castro, 2011) to southern Brazil, including the Gulf of Mexico and Caribbean Sea in the west, and from Portugal to South Africa including the Mediterranean Sea in the east (Compagno, 2001). This species reportedly ranges from intertidal areas to at least $500 \mathrm{~m}$ deep but is mostly found at depths below $100 \mathrm{~m}$ (Compagno, 2001). In this study, however, all bigeye thresher $\mathrm{M} / \mathrm{R}$ locations along the U.S. Atlantic and Gulf coasts were in deep water, on or outside the $200 \mathrm{~m}$ depth contour (Fig. 12b). Locations ranged from offshore of Cape Cod, MA, to Brazil including the Gulf of Mexico and Caribbean Sea, and across the Atlantic between the Equator and $44^{\circ} \mathrm{N}$ latitude. Evidence of bigeye thresher occurrence in the Caribbean Sea includes multiple tagging events and two recaptures. These recaptures showed movement across the Caribbean Sea (tagged SE Puerto Rico, recaptured off Panama; 816 nmi; 2.4 years at liberty) and movement into the Caribbean Sea from the mid-Atlantic (Fig. 12a). The latter recapture is the longest distance traveled $(2,067$ nmi) with the shark tagged at $09^{\circ} 50 \mathrm{~N}$, $32^{\circ} 55 \mathrm{~W}$ and recaptured off Puerto $\mathrm{Ca}$ bello, Venezuela $\left(10^{\circ} 56 \mathrm{~N}, 67^{\circ} 55 \mathrm{~W}\right)$ $(2,067 \mathrm{nmi}$; 9.5 years at liberty). Maximum time at liberty was 10.5 years for a bigeye thresher (Table 1).

\section{Blacktip Shark}

The reported western North Atlantic range for the blacktip shark is from coastal New England to Brazil, including the Gulf of Mexico, and as sightings north of Cape Hatteras, NC (Castro, 2011). The range observed in the CSTP M/R data is from Delaware Bay to French Guiana, including the Gulf of Mexico and Caribbean Sea (Fig. 15b). Seasonal north-south Atlantic coastal migrations occurred with movements across the Gulf of Mexico from Texas to Mexico, and Bimini, Bahamas to Cuba. No migrations were documented between the Atlantic and Gulf of Mexico (Fig. 15a) supporting two stock management (NMFS, 2006). Long distance movements were shown for two blacktip sharks between St. John, U.S. Virgin Islands (USVI) (Caribbean Sea) to Cape Canaveral, FL (1,049 nmi) and Saint Andrew Sound, GA (1,183 nmi-maximum distance traveled). Maximum time at liberty was 9.3 years for a blacktip shark that was tagged and recaptured by biologists and moved from South Carolina to Florida.

\section{Blue Shark}

The blue shark is cosmopolitan in subtropical and temperate oceanic waters (Castro, 2011). In the tropics, the blue shark exhibits tropical submergence where it occurs at greater depths than other areas (Compagno, 1984). Blue sharks have been tagged or recaptured by CSTP participants from Newfoundland and the Gulf of St. Lawrence, Canada, to Argentina in the western Atlantic, including the Gulf of Mexico and Caribbean Sea, and from south of Iceland $\left(57^{\circ} 20 \mathrm{~N}, 19^{\circ} 56 \mathrm{~W}\right)$ to just south of the Equator in the eastern Atlantic including the Mediterranean Sea. Altogether, these areas represent its previously reported range for 
the Atlantic Ocean (Compagno, 2001; Castro, 2011) (Fig. 16d).

The spatial distribution of tags and recaptures over vast areas of the North Atlantic further substantiates one stock for this widely distributed species. Long distance movements of the blue shark were observed between the U.S. Atlantic coast to all parts of the North Atlantic, including Grand Banks of Newfoundland (Canada), Azores, Europe, Mediterranean Sea, Africa, Canary Islands, Cape Verde Islands, South America, Central America, Caribbean Sea, Cuba, and south of the Equator (Fig. 16a). Many of these migrations occurred within one year of tagging (Fig. 16c). Maximum distance traveled was 3,997 nmi for a blue shark tagged off Long Island, NY, and recaptured in the South Atlantic after 8.4 years at liberty (Table 1). In all, ten blue sharks traveled across the Equator from release locations off the U.S. northeast coast (five), Canada (one), United Kingdom (one), Portugal (one), and north of the Equator (two). The southernmost recapture location was for a blue shark tagged north of the equator that moved 1,279 $\mathrm{nmi}$ due south after 65 days at liberty. Other recaptures of blue sharks tagged outside of the U.S. EEZ (Fig. 16b) showed movement between the eastern and western North Atlantic, from the Caribbean Sea to Long Island, NY, and from South America to Canada and the Azores. Multiple fish were tagged and recovered in an area to the west of the Azores and south of the Flemish Cap, showing exchange between this area and all parts of the North Atlantic. The area to the west of the Azores and south of the Flemish Cap has been found to be a discrete central North Atlantic nursery for this species where juveniles can reside for up to at least 2 years (Vandeperre et al., 2014). Maximum time at liberty increased from 8.5 to 15.9 years, approaching maximum age for the species (see details above), for an individual that was tagged north of Cape Cod, MA, and recaptured $873 \mathrm{nmi}$ to the southeast in the open ocean.
Along the U.S. Atlantic coast, blue sharks were caught year round in the offshore waters from Cape Cod, MA, to Florida (Fig. 16e). From December through March, they remained primarily off the continental shelf. In April, some fish were tagged inshore off New York and New Jersey. By May, blue sharks began to move onto the continental shelf from offshore waters and were common inshore from Virginia to Cape Cod, MA. During the warmer months of June through September, they were found closer to shore from New Jersey northward into the Gulf of Maine and off Newfoundland, Canada, but were not abundant on Georges Bank. In the waters off North Carolina and Virginia, this species was more likely to be caught in deeper shelf and adjacent oceanic waters during this time. As the waters cool in October and November, blue sharks began to move offshore and to all parts of the North Atlantic.

\section{Bull Shark}

The bull shark is cosmopolitan in coastal tropical and subtropical seas ranging in the western North Atlantic from Chesapeake Bay, VA (Castro, 2011) to southern Brazil (Compagno, 1984). The CSTP M/R locations extend this range farther north with multiple tags deployed in Delaware Bay (Delaware-New Jersey) (Fig. 18b). Published records farther north are from single strays reported off New Jersey and Massachusetts (Bigelow and Schroeder, 1948). Tagging occurred throughout the Gulf of Mexico and into the Caribbean Sea. Recapture data showed limited movement along the U.S. Atlantic coast, from Bimini, Bahamas to Cuba, and one fish that moved from the U.S. Atlantic coast into the Gulf of Mexico (Fig. 18a). The latter recapture was tagged by a biologist off Delray Beach, FL, and was recaptured west of Naples, FL, after 6.7 years at liberty (maximum time at liberty for a bull shark in the CSTP). In addition, multiple recaptures (6) were from fish tagged in the U.S. Gulf of Mexico and subsequently moved into Mexican coastal waters.
Maximum distance traveled among all tagged bull sharks was $628 \mathrm{nmi}$ from Texas to Veracruz, Mexico, after 2.9 months at liberty.

\section{Common Thresher Shark}

The common thresher shark is distributed worldwide in warm and temperate waters and off the U.S. Atlantic coast primarily from Newfoundland, Canada, to Florida; however, this coastal-pelagic species is reported as not generally found south of Cape Canaveral, FL (Castro, 2011). In the eastern Atlantic, the common thresher shark ranges from Norway to South Africa including the Mediterranean Sea (Compagno, 2011). CSTP data shows tagging locations from Maine to South Carolina in the western Atlantic and Italy and England in the eastern Atlantic (Fig. 19b). A noteworthy location for a common thresher shark was on the Grand Banks of Newfoundland, Canada, tagged by a NMFS biologist in September of 2012. Only four common thresher sharks were recaptured. Two were tagged and recaptured off the northeastern U.S. traveling less than $100 \mathrm{nmi}$ and at liberty for 4.2 and 8.0 years (maximum time at liberty). The other two recaptures were in the eastern Atlantic; one moved from the English Channel to the Bay of Biscay, France, after 2.7 years (271 nmi; maximum distance traveled), and the other was tagged and recaptured off Italy in the Adriatic Sea (6.8 years; 66 nmi) (Fig. 19a).

\section{Crocodile Shark}

The crocodile shark is a little-known, oceanic and circumtropical species, reported in the eastern Atlantic from southeast of the Cape Verde Islands to Guinea-Bissau, Guinea, Angola, and South Africa from the surface to at least $590 \mathrm{~m}$ (Compagno, 2001). In the western North Atlantic, it can be found in the Caribbean Sea with one specimen recorded off Virginia in the Gulf Stream (Castro, 2011). Twenty tagged fish in the CSTP were distributed along the equator from Brazil to Ghana between $0^{\circ}$ and $35^{\circ} \mathrm{W}$ longitude and $2^{\circ} \mathrm{S}$ and $4^{\circ} \mathrm{N}$ latitude (Fig. 20b). None of these tagged fish were recaptured. 


\section{Finetooth Shark}

The finetooth shark inhabits the coastal waters of the western North Atlantic and is reported from North Carolina to Florida, Cuba, Gulf of Mexico, and southern Brazil (Compagno, 1984). Reported specimens north of Cape Hatteras, NC, are considered rare and suspected of species misidentification, as are occurrences in Mexico, Cuba, and the Caribbean (Castro, 2011). CSTP M/R locations for this species were in coastal U.S. waters from Virginia south and into the U.S. Gulf of Mexico to the Mexican border with one fish tagged in Mexican Gulf of Mexico waters (Fig. 22b). Both northernmost (Machipongo, VA) and southernmost (Tamaulipas, Mexico) tags were positively identified by NMFS biologists confirming some of the extremes of the finetooth shark geographic range. Recaptures showed movement along the U.S. east coast between North Carolina and South Carolina and between South Carolina and Florida (Fig. 22a). All of the latter recaptures were tagged by biologists off South Carolina with one of these fish moving $365 \mathrm{nmi}$ south from McClellanville, SC, to Jupiter, FL (maximum distance traveled) after 0.6 years. The one recapture in the Gulf of Mexico (tagged by a biologist) showed movement between St. Vincent Island, FL, and Biloxi, MS (distance of $192 \mathrm{nmi}$; 2.2 years at liberty). Maximum time at liberty was 4.9 years for a finetooth shark and recaptured $5 \mathrm{nmi}$ away after 4.9 years at liberty.

\section{Great Hammerhead}

The great hammerhead is reported to be a coastal-pelagic and semioceanic tropical predator (Compagno, 1984). Its previously recorded western North Atlantic range was from New Jersey (Kohler et al., 1998) to Uruguay (Compagno, 1984). Data presented in the current study document a great hammerhead tagged off Long Island, NY, in late August 2004 at $40^{\circ} 47 \mathrm{~N}, 71^{\circ} 36 \mathrm{~W}$ and is a northern range extension for this species (Fig. $24 b)$. The most northerly occurrenc- es were in the warmer months in summer (New York) and fall (New Jersey) with spring (North Carolina) and winter (Florida) locations further south. Updated tag sites show locations in the USVI and on the south coast of Cuba in the Caribbean Sea. Updated recapture information shows movements in the Gulf of Mexico from Louisiana to the Dry Tortugas, FL, (502 nmi) after 3.4 years at liberty (maximum time at liberty) and from the Florida west coast to Campeche, Mexico (649 nmi; maximum distance traveled) (Fig. 24a).

\section{Longfin Mako}

The longfin mako is an oceanic and tropical species recorded sporadically in the western North Atlantic. Most commonly reported off Cuba, other widely scattered records include Florida, the Bahamas, the Gulf Stream System off the eastern U.S., and southern Brazil (Compagno, 2001). CSTP M/R locations are found in the offshore waters from Cape Cod, MA, to Brazil including the Gulf of Mexico, Caribbean Sea, and east to $36^{\circ} \mathrm{W}$ longitude (Fig. 27b). Recaptures show movement from the Gulf of Mexico to the Atlantic coast of Florida and to the northern coast of Cuba (Fig. 27a). Since Kohler et al. (1998), data were added on two recaptures showing movement from the northern coast of South America (Guyana, Suriname, French Guiana) to Venezuela (Atlantic Ocean to Caribbean Sea) and to Delaware (1,852 nmi; 5.5 years; maximum distance traveled and maximum time at liberty).

\section{Nurse Shark}

The nurse shark is an inshore, demersal shark of the continental and insular shelves in tropical and subtropical waters (Compagno, 2001). The western North Atlantic range is Cape Hatteras, NC, to Brazil with two strays recorded in Chesapeake Bay and off Rhode Island (Bigelow and Schroeder, 1948). CSTP $\mathrm{M} / \mathrm{R}$ locations in this study fall within the reported range for this species, with occurrences from North Carolina to Brazil (Fig. 29b). Movements from the Florida Keys to the Florida east coast (Gulf of Mexico to Atlantic), Texas to Mexico, and from Bimini, Bahamas, to both the Florida east coast and to the northern coast of Cuba (385 nmi, maximum distance traveled) were observed (Fig. 29a). Maximum time at liberty is 11.6 years for a nurse shark tagged and recaptured in the Gulf of Mexico.

The CSTP database has records of two nurse sharks released and recaptured off New Jersey. The two fish were released on the same day from a New Jersey aquarium in September; one was recaptured one day later ( $2 \mathrm{nmi})$ and the other 9 days later (66 nmi). Both were heading south to warmer waters. These two fish (and all fish released from aquaria) were excluded from this atlas because they can show artificial distributions and movements that fall outside of normal species ranges. These types of records may account for some of the reported strays in published literature for this species.

\section{Scalloped Hammerhead}

The scalloped hammerhead has circumglobal distribution in coastal warm temperate and tropical seas, ranging in the western Atlantic from New Jersey to Brazil, including the Gulf of Mexico and Caribbean Sea (Compagno, 1984). CSTP M/R locations extend this range farther north off Long Island, NY, and offshore as far north as $41^{\circ} \mathrm{N}$ latitude (Fig. 35b). Additionally, tagging locations occurred on the Cuban south coast in the Caribbean Sea. Movements took place along the U.S. Atlantic coast with long distance migrations from Florida to North Carolina, Maryland, and New York, and from North Carolina to the southern edge of Georges Bank and to Cuba (Fig. 35a). The latter recapture is the maximum distance traveled for an individual scalloped hammerhead (902 nmi) in the CSTP database. Updated data in the Gulf of Mexico show movements within the Gulf (Mississippi to the Dry Tortugas, FL), between the U.S. and Mexican Gulf of Mexico (Texas to Tampico 
and Campeche, Mexico), and from Gulf waters to the Atlantic (Mississippi to the Atlantic northern coast of Cuba). Maximum time at liberty was 9.6 years for a scalloped hammerhead tagged off Miami Beach, FL, and recaptured off Cape Lookout, NC.

\section{Shortfin Mako}

The shortfin mako is found in all tropical and warm temperate seas (Compagno, 2001). In the western North Atlantic, the species ranges from northeast of the Grand Banks of Newfoundland, Canada (as far north as $\left.50^{\circ} \mathrm{N}\right)($ Castro, 2011) to southern Brazil and possibly northern Argentina, including Bermuda, Gulf of Mexico, and Caribbean (Compagno, 2001). In the eastern Atlantic, it ranges from Norway to South Africa, including the Azores and the Mediterranean Sea (Compagno, 2001). Capture locations in the CSTP M/R data for the shortfin mako in the western Atlantic range from $50^{\circ} \mathrm{N}$ to $40^{\circ} \mathrm{S}$ and confirm locations at the extreme ends of the published range for this species from east of the Flemish Cap in the north to off Buenos Aires, Argentina in the south (Fig. 36d). In the eastern Atlantic, the shortfin mako was tagged from northern Spain to south of the Equator off Gabon $\left(45^{\circ} \mathrm{N}\right.$ to $\left.2^{\circ} \mathrm{S}\right)$. Not commonly reported in the Gulf of Maine (Castro, 2011), updated CSTP data show shortfin mako from Massachusetts to Nova Scotia, Canada (Fig. 36f) and recapture movements into and out of the Gulf of Maine (Fig. 36a). Additional recaptures in the Gulf of Mexico and Caribbean Sea show more evidence of movement between the Atlantic and Gulf of Mexico (both directions), the Atlantic and Caribbean Sea, and between U.S. and Mexican waters of the Gulf.

Long distance shortfin mako recoveries $(>1,000 \mathrm{nmi})$ at liberty for less than one year show interesting results (Fig. 36c). Primarily tagged off the U.S. Northeast Coast, these fish were recaptured in the Gulf of Mexico, Caribbean Sea, mid-Atlantic Ocean, and off Portugal, Morocco, and Western Sahara. The vast majority of shortfin makos were recovered in an area west of the Azores (Fig. 36b); fish tagged in this area show movement to both the U.S. (from Cape Hatteras, NC, to Cape Cod, MA) and west toward Europe. Two shortfin makos tagged off southern Portugal were also recaptured in the area west of the Azores after less than one year at liberty. Updated data show more evidence of shortfin makos crossing the Mid-Atlantic Ridge demonstrating exchange between the western and eastern Atlantic. The maximum distance traveled was 3,043 nmi for a fish that went from Long Island, NY, to Morocco after 2 years at liberty (Table 1). Maximum time at liberty was 12.8 years with five shortfin makos at liberty for over 9 years.

\section{Smooth Dogfish}

The smooth dogfish is an abundant coastal species commonly distributed in bays and inshore waters from Massachusetts southward to Florida and the Gulf of Mexico. They are also found offshore in the Gulf of Mexico (Giresi et al., 2015). Northward dispersal is bounded by Cape Cod, MA, and Nantucket Shoals with occasional strays found in Massachusetts Bay, the Gulf of Maine, and Passamaquoddy Bay at the mouth of the Bay of Fundy (Bigelow and Schroeder, 1948). According to Heemstra (1997), Mustelus canis is replaced by Mustelus canis insularis in the Caribbean Islands, the Bahamas, Cuba, and Bermuda. Recent work in the Gulf of Mexico has suggested the multiple species inhabit this region (smooth dogfish, Florida smoothhound, Mustelus norrisi, and gulf smoothhound, Mustelus sinusmexicanus) (Giresi et al., 2015). These three species can be distinguished by morphological and spatiotemporal factors. It would be impossible to unequivocally state that no cryptic species were tagged; however, all $\mathrm{M} / \mathrm{R}$ locations for smooth dogfish in this study are within the documented geographic and depth range of Mustelus canis (Kohler et al., 2014). Smooth dogfish were tagged from the Gulf of Maine to the Gulf of Mexico (Fig. 39b). Only two fish were tagged in the Gulf of Maine; these fish were caught less than 5 miles from shore, off Ogunquit, ME. Maximum distance traveled was $460 \mathrm{nmi}$ (Table 1) for a smooth dogfish tagged off Martha's Vineyard, MA, and recaptured off Hatteras Inlet, NC, after 1.1 years. The maximum time at liberty was 6.8 years for a female smooth dogfish tagged off Martha's Vineyard, MA, that was recaptured $51 \mathrm{nmi}$ to the west of the tag location. None of the smooth dogfish moved between the Atlantic and Gulf of Mexico (Fig. 39a).

\section{Tiger Shark}

Tiger sharks are a wide-ranging coastal-pelagic species, occurring close to shore and in the open ocean (Compagno, 1984). They are typically considered to be residents of tropical and warm temperate habitats (Ferreira et al., 2015) with seasonal excursions into cool temperate areas (Randall, 1992; Last and Stevens, 1994). The CSTP M/R data (Fig. 42e) show that tiger sharks are caught year round in the Caribbean Sea, Gulf of Mexico, and off the U.S. Atlantic coast as far north as New Jersey. In the warmer months of summer and fall, tiger sharks are found as far north as Cape Cod, MA. Recaptures for this species in the Atlantic using conventional tags has previously shown movements north and south along the U.S. Atlantic coast; from the U.S. Atlantic coast to the Gulf of Mexico, Caribbean Sea, and as far east as $60^{\circ} \mathrm{W}$ longitude; from Bermuda to the Gulf of Mexico; and from the Gulf of Mexico to the U.S. East Coast and Caribbean Sea (Kohler et al., 1998). Updated information on recaptures from this study show more evidence of Gulf of Mexico crossings (north-south, east-west) (Fig. 42b), more exchange between the U.S. Atlantic coast and Gulf of Mexico; more movements into and out of the Caribbean Sea (Fig. 42a), and numerous recapture locations across the North Atlantic Ocean. These long distance movements extend known tiger shark migrations with recapture locations as far north as $45^{\circ} \mathrm{N}$ latitude, as far south as $2.5^{\circ} \mathrm{N}$ latitude (north- 
ern Brazil), and trans-Atlantic movements as far east as the African Coast $\left(15^{\circ} \mathrm{W}\right.$ longitude). Some of these extensive movements ( $>500 \mathrm{nmi}$ ) are accomplished over a short period of time (overall mean time at liberty = 1.0 years) with recapture locations in the Gulf of Mexico, Caribbean Sea, mid-Atlantic, and eastern Atlantic Ocean after less than 1 year at liberty (Fig. 42c). Maximum time at liberty was 11.2 years for a male tiger shark tagged off Cape Hatteras, NC, and recaptured near Atlantis Canyon (a submarine canyon approximately $100 \mathrm{nmi}$ south of Cape Cod, MA). Maximum distance traveled reported in this study was 3,643 nmi for a female tiger shark tagged off St. Augustine, FL, and recaptured west of Guinea-Bissau, Africa after 2.5 years at liberty. This is the longest recorded movement for any tiger shark in the Atlantic Ocean.

\section{Summary}

Twenty years of additional CSTP $\mathrm{M} / \mathrm{R}$ data provide further insight into the distributions and movements of the 35 species of Atlantic sharks examined. Distances traveled have been extended for 20 species, some of which showed exchange into all parts of the Atlantic Ocean and associated seas. Times at liberty have been extended for 22 species with some maximums verifying published longevity estimates. In addition, seasonal distributions have been included in specific bodies of water. These accomplishments would be nearly impossible for an individual, or an individual institution or agency, to mark and recapture the number of fish over the geographic and decadal scale as has been achieved by the CSTP — a collective of thousands of knowledgeable volunteer recreational and commercial fishermen. This research is accomplished for little more than the cost of the tags making the cost/benefit ratio for this program extremely low. The information collected by CSTP volunteers is a form of public participation in scientific research (PPSR) or citizen science (Bonney et al., 2009). The CSTP creates an enormous body of scientific data for under- standing distributions and migration patterns for shark species. A further benefit to PPSR is that tagging has become a socially acceptable component to recreational fishing, wherein many anglers solely practice catch, tag, and release (van der Elst, 1990). The old adage "the only good shark is a dead shark" is changing, due partly to the education received by shark fishermen through this volunteer shark tagging program.

Conventional tags continue to have a valuable role to play in shark conservation and management. Despite advances in electronic tagging technology, the geographic distributions and movements for most shark species remain largely unknown (Sims, 2010). Such information, particularly over large spatial and temporal scales, is essential for the development of appropriate management strategies (Ferreira et al., 2015) and in determining the usefulness of conservation measures (Sims, 2010). The wealth of data garnered from the CSTP highlights the importance of continuing these longterm tagging programs (Frazier et al., 2015). Given the fact that shark species are slow growing, long-lived, and highly mobile, with relatively low return rates for tagged sharks-continued tagging efforts are essential to provide this critical life history and population dynamics information.

It is well established that many shark species segregate by size and sex (Springer 1960; Clark and von Schmidt 1965) and undergo partial migrations (Papastamatiou et al., 2013; Secor, 2015) throughout their lives with the existence of discrete locations for key life history events, such as pupping, and mating (Sims, 2010; Vandeperre et al., 2014). There is also a distinct seasonal component to these movements. Understanding these differential migration patterns is crucial for future conservation efforts (Lea et al., 2015) since long distance movements could bring different segments of a population into contact with multiple habitats, ecosystems, anthropogenic threats (Ferreira et al., 2015), and overlap with fishing activ- ity (Queiroz et al., 2016). Finer scale analysis of the CSTP M/R database will help bring to light some of these patterns. Future studies of animal movements need to be more broadly based, linking migration research with ecological and biogeographic studies (Dingle and Drake, 2007) to begin to understand the mechanisms and basic driving forces for migration (Alerstam et al., 2003; Ramenofsky and Wingfield, 2007). In addition, the integration of tagging and population dynamics modelling can greatly enhance the management and conservation of highly mobile species such as sharks (Aires-da-Silva et al., 2009; Braccini et al., 2016).

\section{Acknowledgments}

This report is dedicated to Jack Casey whose tremendous foresight and determination created the Cooperative Shark Tagging Program over 50 years ago. Through his passion, personality, and drive, he created a vast network of enthusiastic and knowledgeable volunteer taggers who he called "our windows to the sea." We gratefully recognize those thousands of sport and commercial fishermen, fisheries observers, research vessel captains and crew, tournament officials, and cooperating scientists who have helped make this one of the largest shark tagging programs in the world; many thanks to all of you for your dedication and support of our program. Special acknowledgements to past and present Apex Predators staff, including Ruth Briggs, Lisa J. Natanson, Cami McCandless, John Hoey, Gregg Skomal, Chuck Stillwell, H. Wes Pratt, Joe Mello, Mike Couturier, Fred Lerch, Larry Lindgren, Nancy Kelley, and Patricia Hadfield for their assistance and support with data collection and processing. We are also grateful to Lisa J. Natanson and Richard McBride for editing the manuscript and helping with the overall layout, and Kathy Duffy and Jon Hare for providing valuable technical assistance. We especially thank Lisa J. Natanson for the final push over the finish line. 


\section{Literature Cited}

Aires-da-Silva, A. M., M. N. Maunder, V. F. Gallucci, N. E. Kohler, and J. J. Hoey. 2009. A spatially structured tagging model to estimate movement and fishing mortality rates for the blue shark (Prionace glauca) in the North Atlantic Ocean. Mar. Freshw. Res. 60:1,029-1,043 (doi: https://doi.org/10.1071/ MF08235).

Alerstam, T., A. Hedenstr m, and S. Åkesson. 2003. Long-distance migration: evolution and determinants. Oikos 103:247-260 (doi: https://doi.org/10.1034/j.1600-0706.2003. 12559.x)

Andrews, A. H., L. J. Natanson, L. A. Kerr, G. H. Burgess, and G. M. Cailliet. 2011. Bomb radiocarbon and tag-recapture dating of sandbar shark (Carcharhinus plumbeus). Fish. Bull. 109:454-465.

Bigelow, H. B., and W. C. Schroeder. 1948. Fishes of the western North Atlantic, lancelets, cyclostomes, and sharks. Memoir No. 1, Part 1. Sears Found. Mar. Res., Yale Univ., New Haven, Conn., 576 p.

Bonney, R., C. B. Cooper, J. Dickinson, S. Kelling, T. Phillips, K. V. Rosenberg, and J. Shirk. 2009. Citizen science: a developing tool for expanding science knowledge and scientific literacy. BioScience 59(11):977-984 (doi: https://doi.org/10.1525/bio.2009.59.11.9).

Braccini, M., A. Aires-da-Silva, and I. Taylor. 2016. Incorporating movement in the modelling of shark and ray population dynamics: approaches and management implications. Rev. Fish Biol. Fish. 26(1):13-24 (doi: https://doi.org/10.1007/s11160-015-9406-x).

Brooks, E. N., J. E. Powers, and E. Cortes. 2010. Analytical reference points for age-structured models: application to data-poor fisheries. ICES J. Mar. Sci. 67:165-175 (doi: https:// doi.org/10.1093/icesjms/fsp225).

Bruce, B. D. 1992. Preliminary observations on the biology of the white shark, Carcharodon carcharias, in South Australian waters. In J. G. Pepperell (Editor), Sharks: Biology and Fisheries. Aust. J. Mar. Freshw. Res. 43:1-11.

Campana, S. E. 2016. Transboundary movements, unmonitored fishing mortality, and ineffective international fisheries management pose risks for pelagic sharks in the Northwest Atlantic. Can. J. Fish. Aquat. Sci. 73(10):1,599-1,607 (doi: https://doi. org/10.1139/cjfas-2015-0502).

Casey, J. G. 1985. Transatlantic migrations of the blue shark: a case history of cooperative shark tagging. In R. H. Stroud (Editor), World Angling Resources and Challenges: Proceedings of the First World Angling Conference, p. 253-268. Cap d'Agde, France, Sept. 12-18 1984. Int. Game Fish Assoc. Ft. Lauderdale, Fla.

and N. E. Kohler. 1992. Tagging studies on the shortfin mako shark Isurus oxyrinchus in the western North Atlantic. In J. G. Pepperell (Editor), Sharks: biology and fisheries. Aust. J. Mar. Freshw. Res. 43:4560 .

and L. J. Natanson. 1992. Revised estimates of age and growth of the sandbar shark (Carcharhinus plumbeus) from the western North Atlantic. Can. J. Fish. Aquat. Sci. 49:1,474-1,477 (doi: https://doi. org/10.1139/f92-162)

Castro, J. I. 2011. The sharks of North America. Oxford Univ. Press, Inc., N.Y., 613 p.
Clarke, T. A. 1971. The ecology of the scalloped hammerhead shark, Sphyrna lewini, in Hawaii. Pac. Sci. 25:133-144 (online at http:// hdl.handle.net/10125/4191).

Clark, E., and K. von Schmidt. 1965. Sharks of the central gulf coast of Florida. Bull. Mar. Sci. 15(1):13-83.

Compagno, L. J. V. 1984. FAO Species Catalogue. Vol. 4. Sharks of the world. An annotated and illustrated catalogue of shark species known to date. Part 2. Carcharhiniformes. FAO Fish. Synop. 125(4):251-655 2001. Sharks of the world. An annotated and illustrated catalogue of shark species known to date. Vol. 2. Bullhead, mackerel, and carpet sharks (Heterodontiformes, Lamniformes and Orectolobiformes). FAO Spec. Cat. 2(1), Rome, 269 p.

Dingle, H., and V. A. Drake. 2007. What is migration? BioScience 57(2):113-143.

Everhart, W. H., and W. D. Youngs. 1981. Principles of fishery science. Cornell Univ. Press, Ithaca, $349 \mathrm{p}$

Ferreira, L. C., M. Thums, J. J. Meeuwig, G. M. S. Vianna, J. Stevens, R. McAuley, and M. G. Meekan. 2015. Crossing latitudeslong distance tracking of an apex predator. PLoS ONE 10(2):e0116916 (doi: https://doi. org/10.1371/journal.pone.0116916).

Francis, M. P. 1988. Movement patterns of rig (Mustelus lenticulatus) tagged in southern New Zealand. N. Z. J. Mar. Freshw. Res. 22:259-272 (doi: https://doi.org/10.1080/002 $88330.1988 .9516298)$.

Frazier, B. S., W. B. Driggers III, and G. F. U1rich. 2015. Longevity of Atlantic sharpnose sharks Rhizoprionodon terraenovae and blacknose sharks Carcharhinus acronotus in the western North Atlantic Ocean based on tagrecapture data and direct age estimates (ver. 2; referees: 2 approved). F1000Research 2015 3:190 (doi: https://doi.org/10.12688/f1000research.4767.2).

Giresi, M. M., R. D. Grubbs, D. S. Portnoy, W. B. Driggers III, L. Jones, and J. R. Gold. 2015. Identification and distribution of morphologically conserved smoothhound sharks in the Northern Gulf of Mexico. Trans. Amer. Fish. Soc. 144:1301-1310 (doi: https://doi.or $\mathrm{g} / 10.1080 / 00028487.2015 .1069212$ )

Gordon, W. G. 1990. Fish marking and the Magnuson Act. Am. Fish. Soc. Symp. 7:1-4.

Harden Jones, F. R. 1968. Fish migration. Edward Arnold, London, 325 p.

Heemstra, P. C. 1997. A review of the smoothhound sharks (genus Mustelus, family Triakidae) of the western Atlantic Ocean, with descriptions of two new species and a new subspecies. Bull. Mar. Sci. 60(3):894-928.

Holland, G. A. 1957. Migration and growth of the dogfish shark, Squalus acanthias (Linnaeus), of the eastern North Pacific. Wash. Dep. Fish. Fish. Res. Pap. 2(1):43-59.

Jensen, A. C., R. L. Edwards, and G. C. Matthiessen. 1961. The spiny dogfish-a review. Woods Hole Lab. Rep. 61(7):1-42 (Online at https://www.nefsc.noaa.gov/publications/series/whlrd/whlrd6107.pdf).

Kneebone, J., J. Chisholm, and G. B. Skomal. 2012. Seasonal residency, habitat use, and site fidelity of juvenile sand tiger sharks Carcharias taurus in a Massachusetts estuary. Mar. Ecol. Prog. Ser. 471:165-U186 (doi: https://doi.org/10.3354/meps09989).

Kohler, N. E., and P. A. Turner. 2001. Shark tagging: a review of conventional methods and studies. Environ. Biol. Fish. 60:191-223 (doi: https://doi.org/10.1023/A:1007679303082).

J. G. Casey, and P. A. Turner. 1998

NMFS Cooperative Shark Tagging Program, 1962-1993: an atlas of shark tag and recapture data. Mar. Fish. Rev. 60(2):1-87.

P. A. Turner, M. Pezzullo, and C. T. McCandless. 2014. Mark/recapture data for the smooth dogfish, Mustelus canis, in the western North Atlantic from the NMFS Cooperative Shark Tagging Program. SEDAR39-DW-20, 24 p. (Avail. online at http:// www.sedarweb.org/sedar-39)

Last, P. R., and J. D. Stevens. 1994. Sharks and rays of Australia. Victoria, Australia: CSIRO, $513 \mathrm{p}$.

Lea, J. S., B. M. Wetherbee, N. Queiroz, N. Burnie, C. Aming, L. L. Sousa, G. R. Mucientes, N. E. Humphries, G. M. Harvey, D. W. Sims, and M. S. Shivji. 2015. Repeated, longdistance migrations by a philopatric predator targeting highly contrasting ecosystems. Sci. Rep. 5:11202 (doi: https://doi.org/10.1038 srep 11202)

McCandless, C. T., N. E. Kohler, and Harold L. Pratt, Jr. 2007. Shark nursery grounds of the Gulf of Mexico and the East Coast waters of the United States. Amer. Fish. Soc., Symp. 50. Bethesda, MD, $390 \mathrm{p}$.

McLaughlin, R. H., and A. K. O'Gower. 1971. Life history and underwater studies of a heterodont shark. Ecol. Monogr. 41(4):271-289 (doi: https://doi.org/10.2307/1948494).

Natanson, L. J., J. J. Mello, and S. E. Campana. 2002. Validated age and growth of the porbeagle shark (Lamna nasus) in the western North Atlantic Ocean. Fish. Bull. 100:266278

N. E. Kohler, D. Ardizzone, G. M. Cailliet, S. P. Wintner, and H. F. Mollet. 2006. Validated age and growth estimates for the shortfin mako, Isurus oxyrinchus, in the North Atlantic Ocean. Environ. Biol. Fish. 77:367-383 (doi: https://doi.org/10.1007/ s10641-006-9127-z).

NMFS (National Marine Fisheries Service). 2006. Southeast Data Assessment and Review (SEDAR) 11 - Large Coastal Shark Complex, Blacktip Shark, and Sandbar Shark Stock Assessment Report. NMFS Highly Migratory Species Management Division, Silver Spring, MD, 387 p. (Online at http://sedarweb.org/docs/sar/Final_LCS_SAR.pdf).

Olsen, A. M. 1984. Synopsis of biological data on the school shark Galeorhinus australis (Macleay 1881). FAO Fish. Synop. 139, 42 p. (Online at http://www.fao.org/3/a-ap941e. pdf).

Papastamatiou, Y. P., C. G. Meyer, F. Carvalho, J. J. Dale, M. R. Hutchinson, and K. N. Holland. 2013. Telemetry and random-walk models reveal complex patterns of partial migration in a large marine predator. Ecology 94(11):2,595-2,606 (doi: https://doi. org/10.1890/12-2014.1)

Pine, W. E., K. H. Pollock, J. E. Hightower, T. J. Kwak, and J. A. Rice. 2003. A review of tagging methods for estimating fish population size and components of mortality. Fisheries 28(10):10-23 (doi: https://doi. org/10.1577/1548-8446(2003)28[10:AROTM $\mathrm{F}] 2.0 . \mathrm{CO} ; 2$ )

Pollock, K. H, J. M. Hoenig, W. S. Hearn, and B. Calingaert. 2001. Tag reporting rate estimation: 1. an evaluation of the high-reward tagging method. N. Am. J. Fish. Manage. 21: 
521-532 (doi: https://doi.org/10.1577/15488675(2001)021<0521:TRREAE $>2.0 . \mathrm{CO} ; 2)$.

Portnoy, D. S., J. B. Puritz, C. M. Hollenbeck, J. Gelsleichter, D. Chapman, and J. R. Gold. 2015. Selection and sex-biased dispersal in a coastal shark: the influence of philopatry on adaptive variation. Mol. Ecol. 24:5,877-5,885 (doi: https://doi.org/10.1111/mec.13441).

Queiroz, N., N. E. Humphries, G. Mucientes, N. Hammerschlag, F. P. Lima, K. L. Scales, P. I. Miller, L. L. Sousa, R. Seabra, and D. W. Sims. 2016. Ocean-wide tracking of pelagic sharks reveals extent of overlap with longline fishing hotspots. PNAS 113(6):1,582-1,587.

Ramenofsky, M., and J. C. Wingfield. 2007. Regulation of migration. BioScience. 57:135-143 (doi: https://doi.org/10.1641/B570208).

Randall, J. E. 1992. Review of the biology of the tiger shark (Galeocerdo cuvier). Aust. J. Mar. Freshw. Res. 43:21-31 (doi: https://doi. org/10.1071/MF9920021).

Rounsefell, G. A., and W. H. Everhart. 1953. Fishery science-its methods and applications. John Wiley \& Sons, Inc., NY, 444 p.
Schulze-Haugen M., T. Corey, and N. E. Kohler. 2003. Sharks, tunas \& billfishes of the U.S Atlantic \& Gulf of Mexico. Rhode Island Sea Grant, 118 p.

Secor, D. H. 2015. Migration ecology of marine fishes. John Hopkins Univ. Press, Baltimore, MD, $292 \mathrm{p}$

Sims, D. W. 2010. Tracking and analysis tech niques for understanding free-ranging shark movements and behavior. In J. C. Carrier, J. A. Musick, and M. R. Heithaus (Editors) Sharks and their relatives II: biodiversity, adaptive physiology, and conservation, $\mathrm{p}$ 351-392. CRC Mar. Biol. Series, Boca Raton.

Skomal, G. B., and L. J. Natanson. 2003. Age and growth of the blue shark (Prionace glau$c a)$ in the North Atlantic Ocean. Fish. Bull. 101:627-639.

Speed, C. W., I. C. Field, M. G. Meekan, and C. J. A. Bradshaw. 2010. Complexities of coastal shark movements and their implications for management. Mar. Ecol. Prog. Ser. 408:275-305 (doi: https://doi.org/10.3354/ meps08581).
Springer, S. 1960. Natural history of the sandba shark Eulamia milberti. Fish. Bull. 61:1-38.

Stevens, J. D. 1976. First results of shark tagging in the north-east Atlantic, 1972-1975. J. Mar. Biol. Ass. U. K. 56:929-937 (doi: https://doi. org/10.1017/S002531540002097X)

Templeman, W. 1976. Transatlantic migrations of spiny dogfish (Squalus acanthias). J. Fish. Res. Board Can. 33:2605-2609 (doi: https:// doi.org/10.1139/f76-308).

Tricas, T. C. 1977. Food habits, movements, and seasonal abundance of the blue shark, Prionace glauca (Carcharhinidae), in southern California waters. M.S. Thesis, Calif. State Univ., Long Beach, CA, 79 p.

van der Elst, R. P. 1990. Marine fish tagging in South Africa. Am. Fish. Soc. Symp. 7:854 862.

Vandeperre, F., A. Aires-da-Silva, J. Fontes, M. Santos, R. Serrão Santos, and P. Afonso. 2014. Movements of blue sharks (Prionace glauca) across their life history. PLoS ONE 9(8):e103538 (doi: https://doi.org10.1371/ journal.pone.0103538). 


\section{Atlantic Angel Shark}

\begin{tabular}{|c|c|c|c|c|c|c|c|}
\hline Sex & Tags & Recaptures & $\begin{array}{c}\text { Recapture rate } \\
(\%)\end{array}$ & $\begin{array}{l}\text { Mean distance } \\
\text { traveled (nmi) }\end{array}$ & $\begin{array}{l}\text { Maximum distance } \\
\text { traveled (nmi) }\end{array}$ & $\begin{array}{l}\text { Mean time at } \\
\text { liberty (years) }\end{array}$ & $\begin{array}{l}\text { Maximum time } \\
\text { at liberty (years) }\end{array}$ \\
\hline Male & 74 & 0 & 0.0 & & & & \\
\hline Female & 74 & 0 & 0.0 & & & & \\
\hline Unknown & 22 & 0 & 0.0 & & & & \\
\hline Total & 170 & 0 & 0.0 & & & & \\
\hline
\end{tabular}

\section{Yearly Summary of Tags}
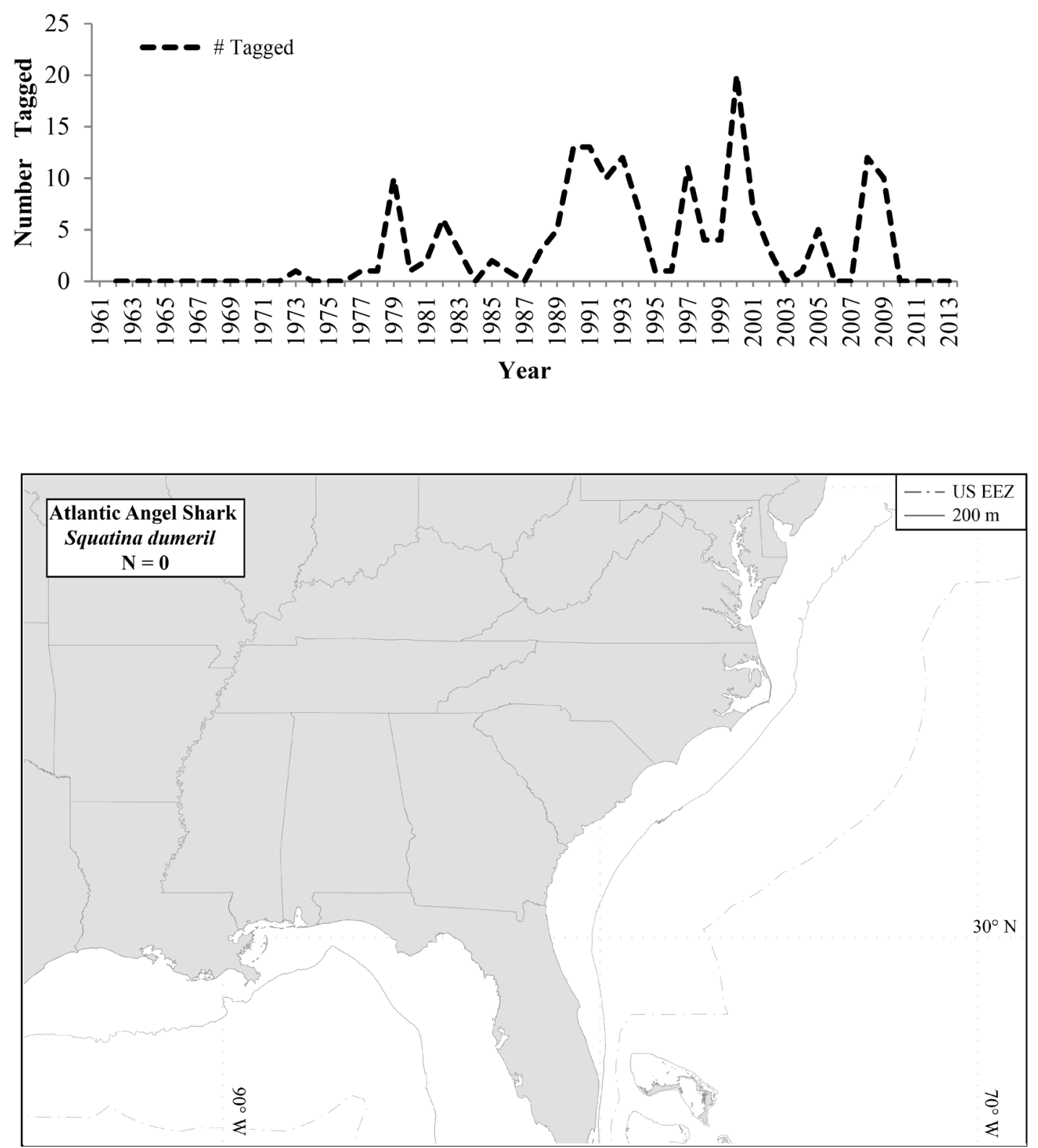

Figure 9a.-Distribution of recapture locations for the Atlantic angel shark, Squatina dumeril, from the NMFS Cooperative Shark Tagging Program (1962-2013). 


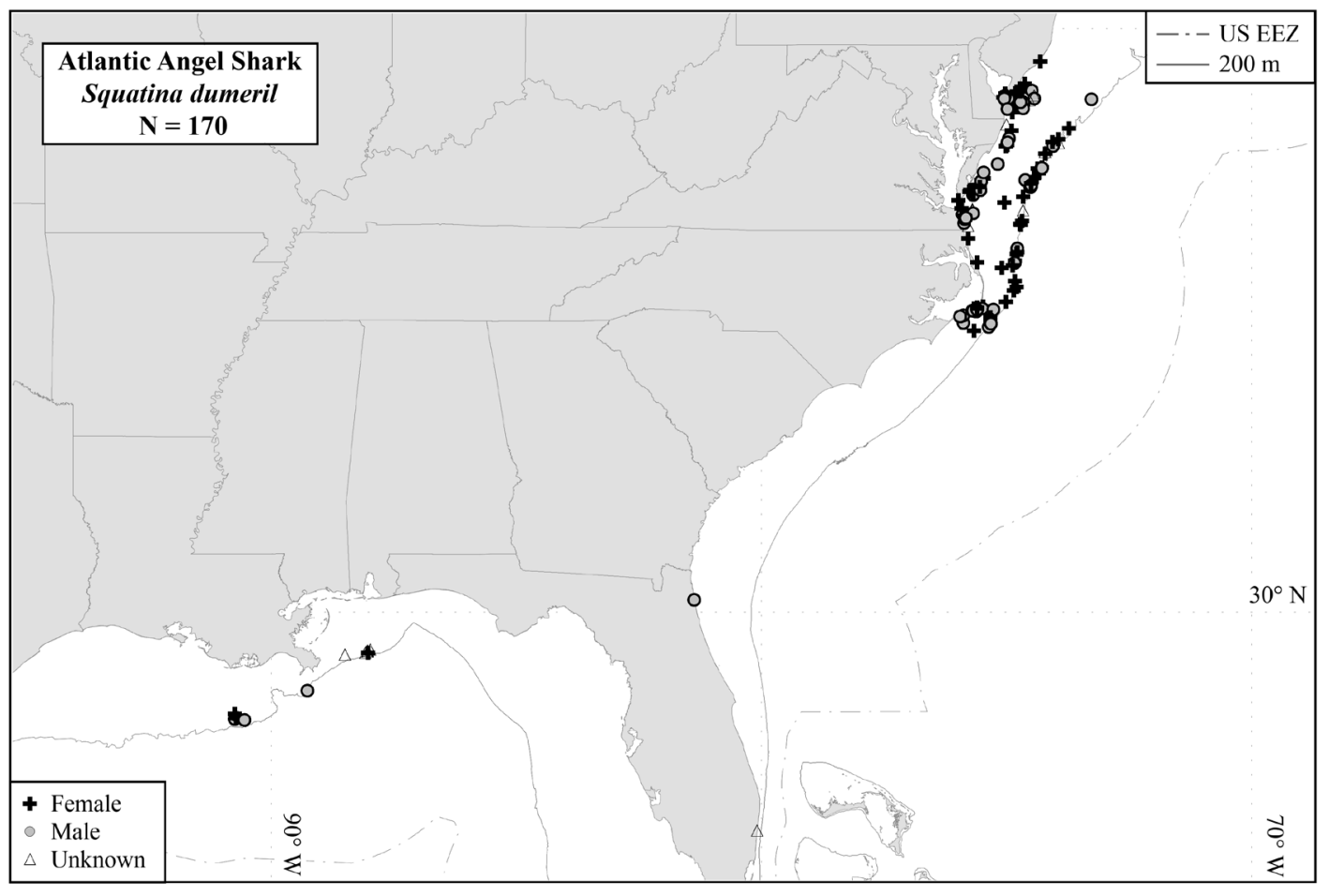

Figure 9b.-Distribution of mark/recapture locations for the Atlantic angel shark, Squatina dumeril, from the NMFS Cooperative Shark Tagging Program (1962-2013).
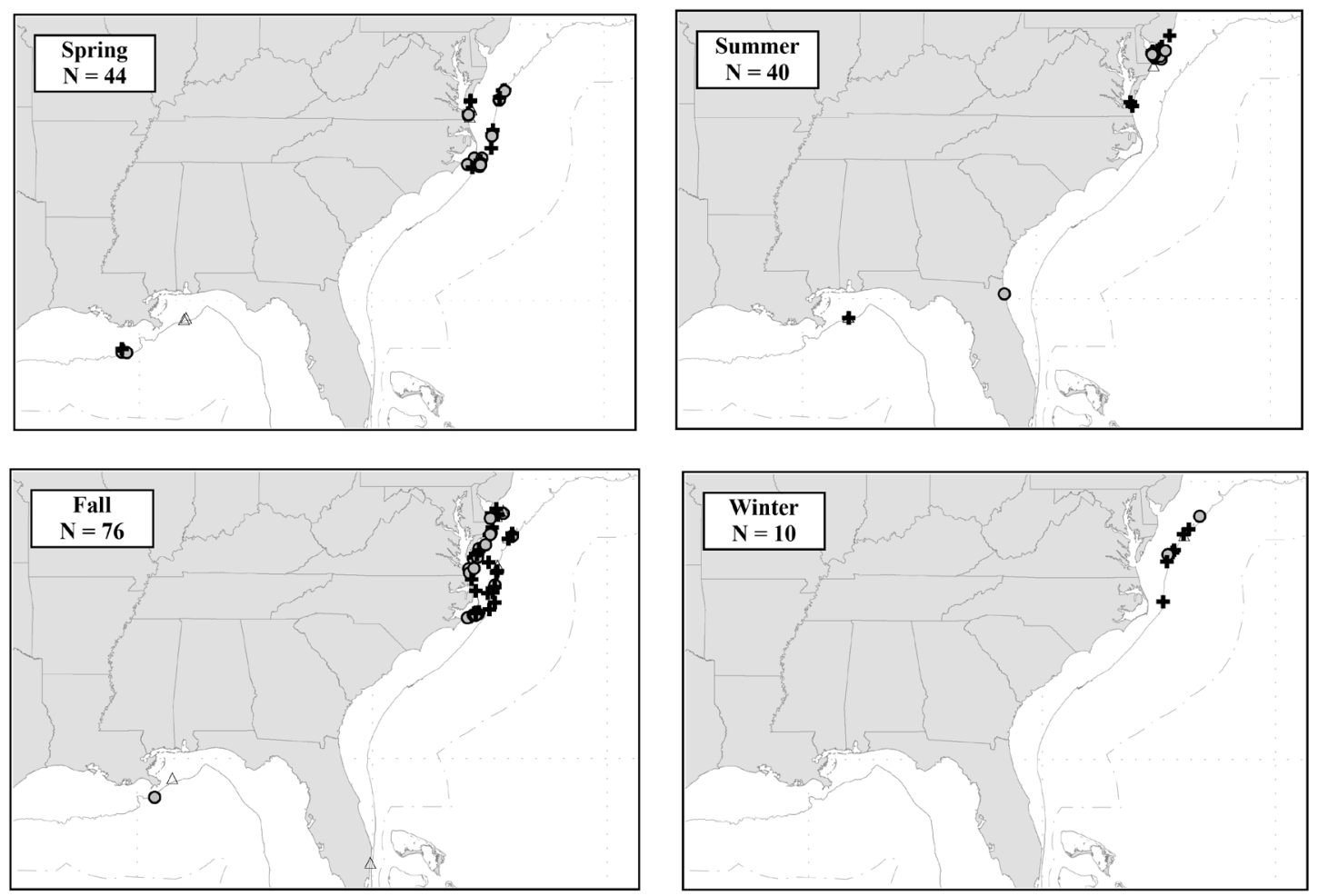

Figure 9c.-Seasonal distribution of mark/recapture locations for the Atlantic angel shark, Squatina dumeril, from the NMFS Cooperative Shark Tagging Program (1962-2013). 


\section{Atlantic Sharpnose Shark}

\begin{tabular}{|c|c|c|c|c|c|c|c|}
\hline Sex & Tags & Recaptures & $\begin{array}{l}\text { Recapture rate } \\
\text { (\%) }\end{array}$ & $\begin{array}{l}\text { Mean distance } \\
\text { traveled (nmi) }\end{array}$ & $\begin{array}{l}\text { Maximum distance } \\
\text { traveled (nmi) }\end{array}$ & $\begin{array}{l}\text { Mean time at } \\
\text { liberty (years) }\end{array}$ & $\begin{array}{l}\text { Maximum time } \\
\text { at liberty (years) }\end{array}$ \\
\hline Male & 2,903 & 48 & 1.7 & 93.6 & 570 & 1.9 & 7.3 \\
\hline Female & 1,804 & 20 & 1.1 & 118.1 & 337 & 2.3 & 6.1 \\
\hline Unknown & 270 & 11 & 4.1 & 99.0 & 297 & 1.8 & 6.5 \\
\hline Total & 4,977 & 79 & 1.6 & 100.6 & 570 & 2.0 & 7.3 \\
\hline
\end{tabular}

Yearly Summary of Tags, Recaptures, and Recapture Rate
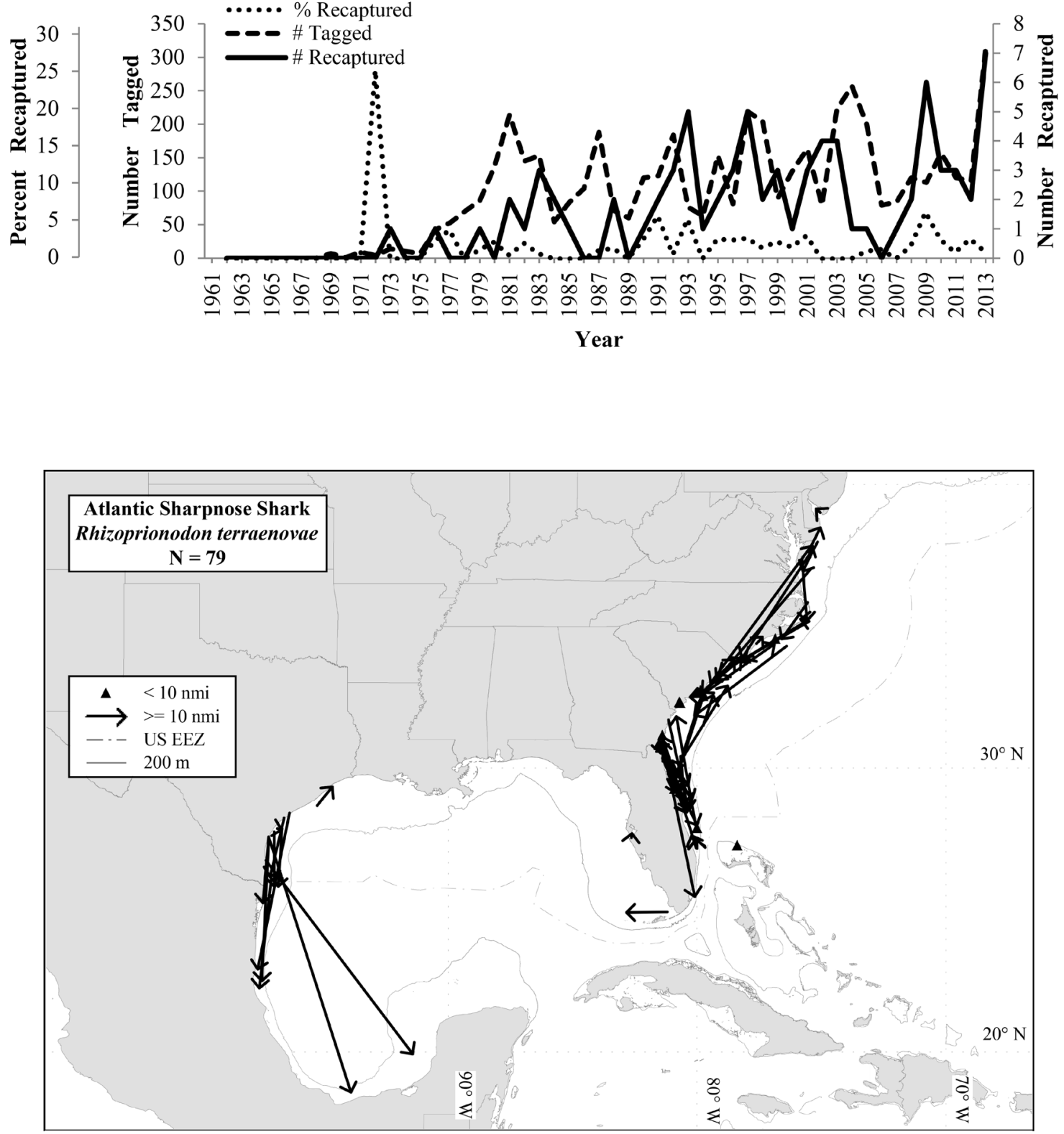

Figure 10a.-Distribution of recapture locations for the Atlantic sharpnose shark, Rhizoprionodon terraenovae, from the NMFS Cooperative Shark Tagging Program (1962-2013). 


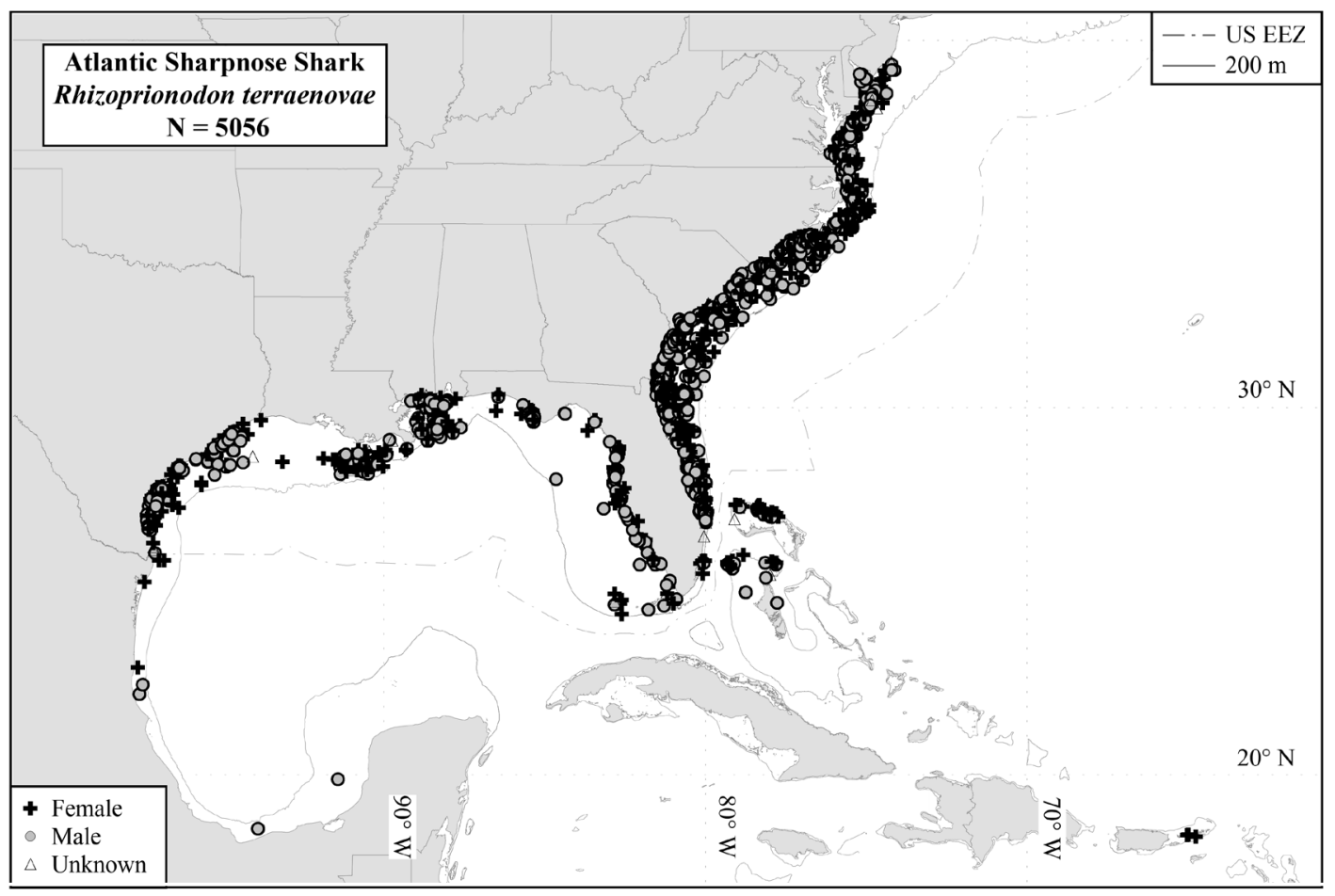

Figure 10b.-Distribution of mark/recapture locations for the Atlantic sharpnose shark, Rhizoprionodon terraenovae, from the NMFS Cooperative Shark Tagging Program (1962-2013).
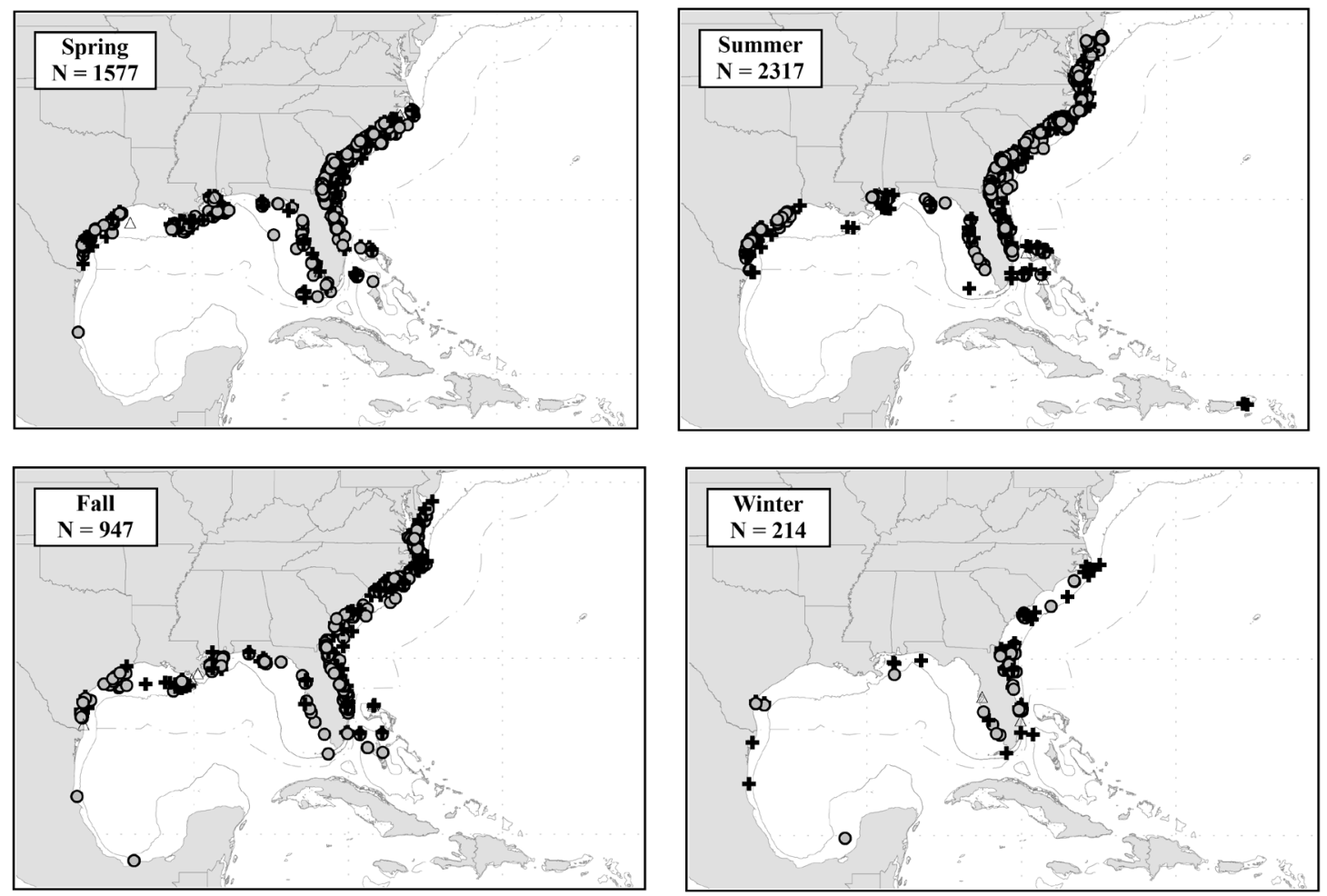

Figure 10c.- Seasonal distribution of mark/recapture locations for the Atlantic sharpnose shark, Rhizoprionodon terraenovae, from the NMFS Cooperative Shark Tagging Program (1962-2013). 


\section{Basking Shark}

\begin{tabular}{|c|c|c|c|c|c|c|c|}
\hline Sex & Tags & Recaptures & $\begin{array}{c}\text { Recapture rate } \\
(\%)\end{array}$ & $\begin{array}{l}\text { Mean distance } \\
\text { traveled (nmi) }\end{array}$ & $\begin{array}{l}\text { Maximum distance } \\
\text { traveled }(\mathrm{nmi})\end{array}$ & $\begin{array}{l}\text { Mean time at } \\
\text { liberty (years) }\end{array}$ & $\begin{array}{l}\text { Maximum time } \\
\text { at liberty (years) }\end{array}$ \\
\hline Male & 46 & 0 & 0.0 & & & & \\
\hline Female & 31 & 0 & 0.0 & & & & \\
\hline Unknown & 91 & 0 & 0.0 & & & & \\
\hline Total & 168 & 0 & 0.0 & & & & \\
\hline
\end{tabular}

\section{Yearly Summary of Tags}
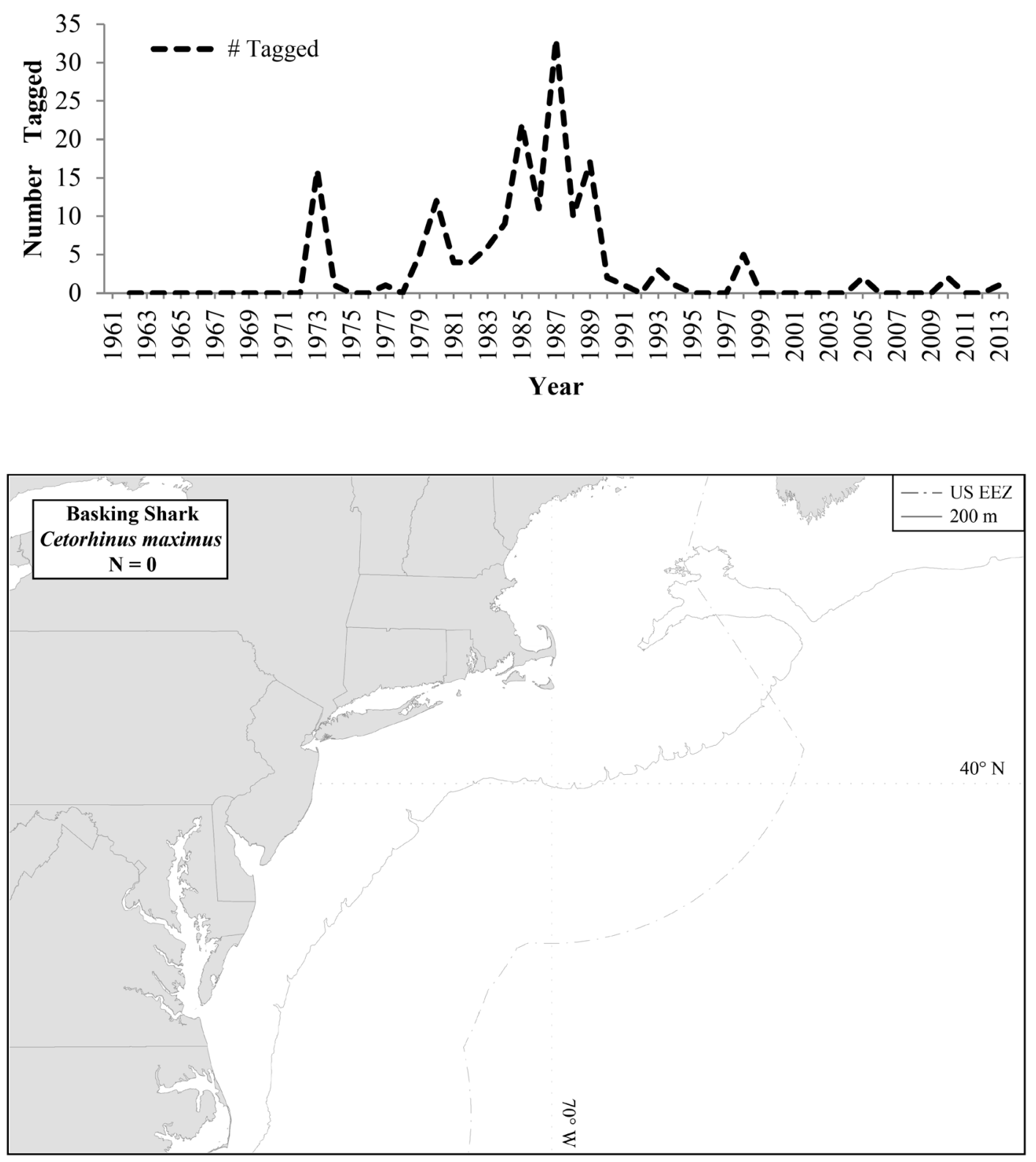

Figure 11a.-Distribution of recapture locations for the basking shark, Cetorhinus maximus, from the NMFS Cooperative Shark Tagging Program (1962-2013). 


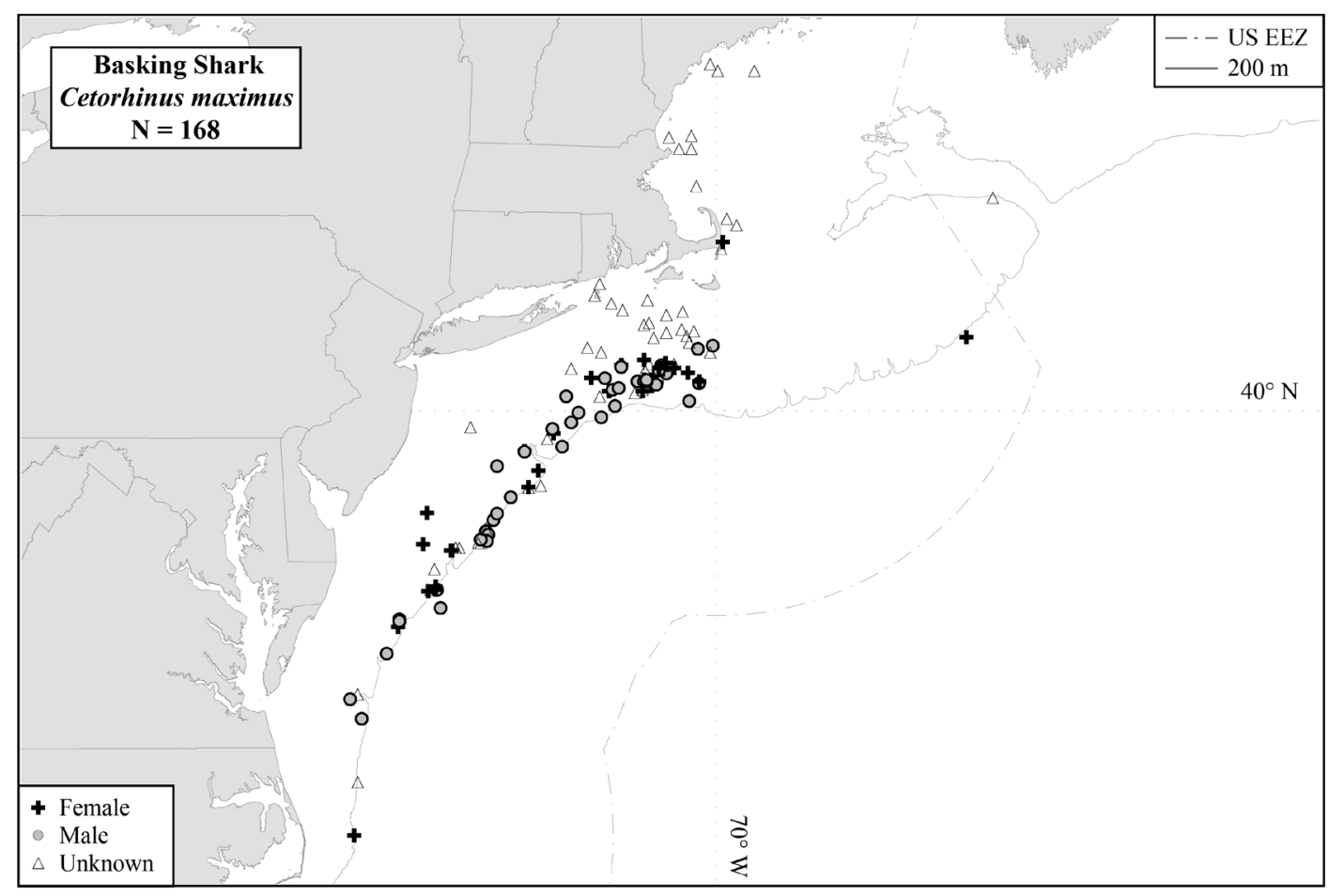

Figure 11b.-Distribution of mark/recapture locations for the basking shark, Cetorhinus maximus, from the NMFS Cooperative Shark Tagging Program (1962-2013).
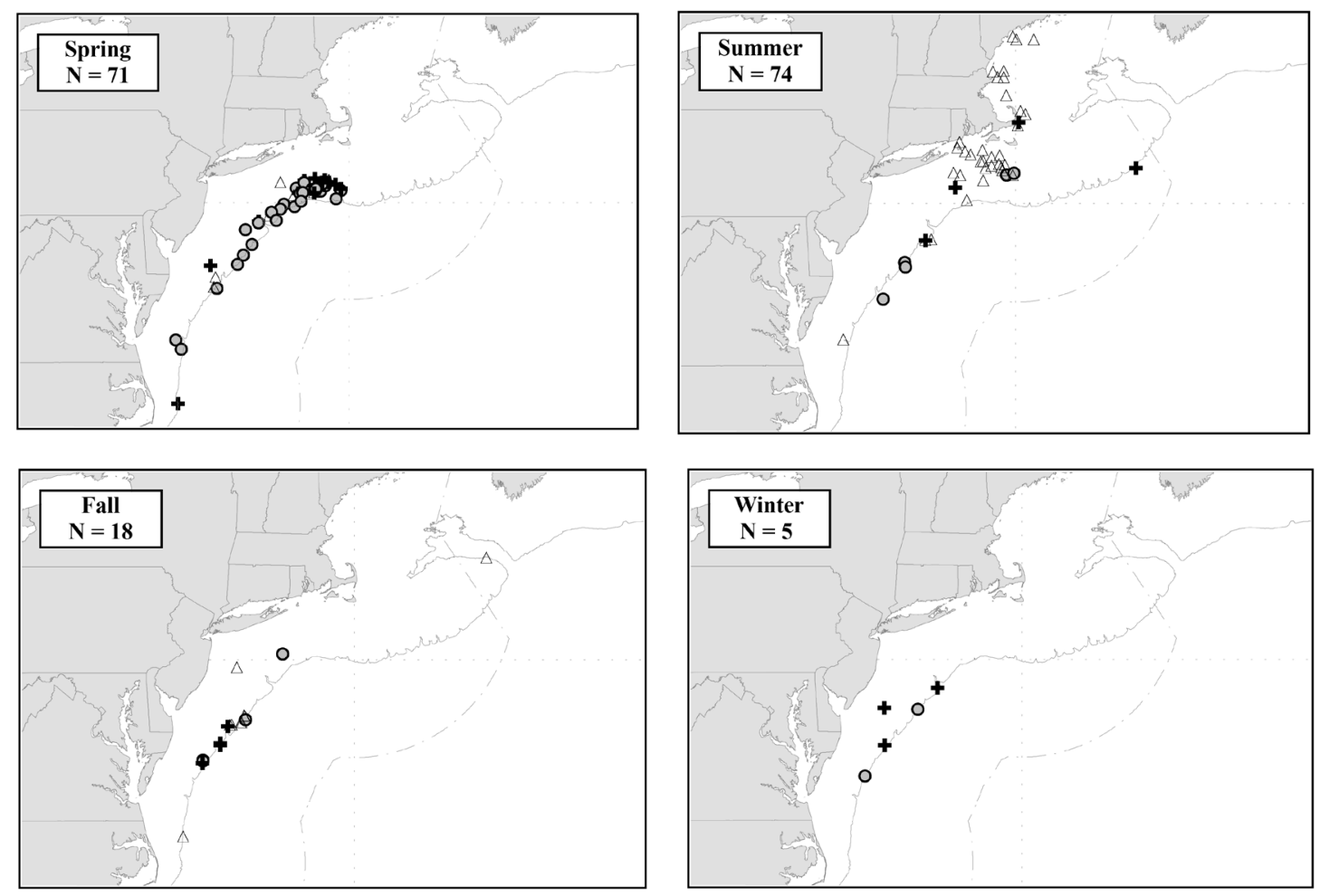

Figure 11c.- Seasonal distribution of mark/recapture locations for the basking shark, Cetorhinus maximus, from the NMFS Cooperative Shark Tagging Program (1962-2013). 


\section{Bigeye Thresher}

\begin{tabular}{|c|c|c|c|c|c|c|c|}
\hline Sex & Tags & Recaptures & $\begin{array}{c}\text { Recapture rate } \\
(\%)\end{array}$ & $\begin{array}{l}\text { Mean distance } \\
\text { traveled (nmi) }\end{array}$ & $\begin{array}{l}\text { Maximum distance } \\
\text { traveled (nmi) }\end{array}$ & $\begin{array}{l}\text { Mean time at } \\
\text { liberty (years) }\end{array}$ & $\begin{array}{l}\text { Maximum time } \\
\text { at liberty (years) }\end{array}$ \\
\hline Male & 112 & 2 & 1.8 & 238.5 & 366 & 5.0 & 5.7 \\
\hline Female & 120 & 3 & 2.5 & 900.0 & 1,100 & 6.3 & 10.5 \\
\hline Unknown & 168 & 7 & 4.2 & 826.1 & 2,067 & 5.6 & 9.6 \\
\hline Total & 400 & 12 & 3.0 & 746.7 & 2,067 & 5.7 & 10.5 \\
\hline
\end{tabular}

\section{Yearly Summary of Tags, Recaptures, and Recapture Rate}

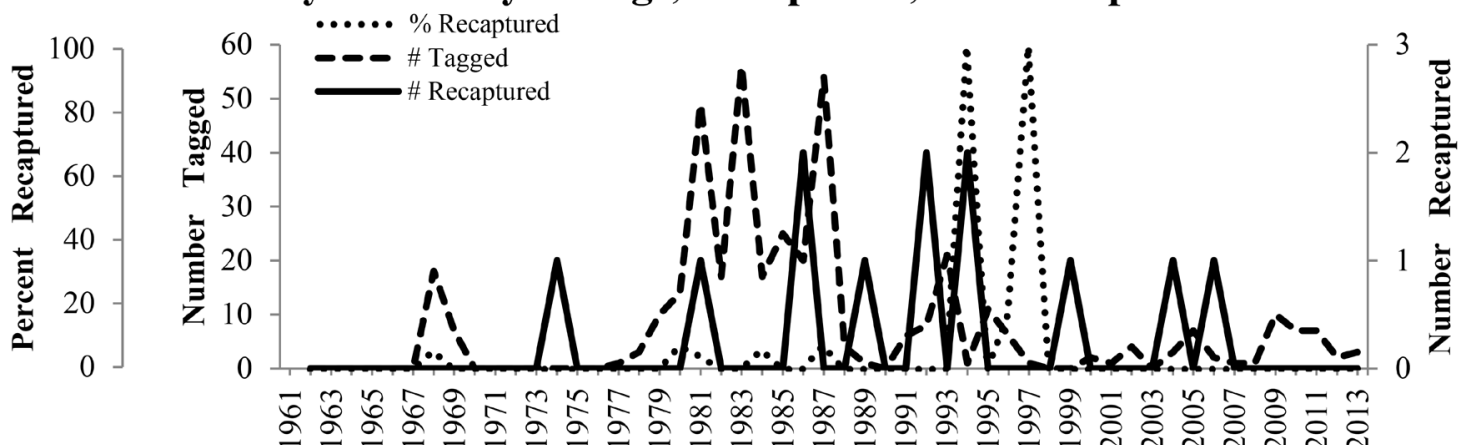

Year

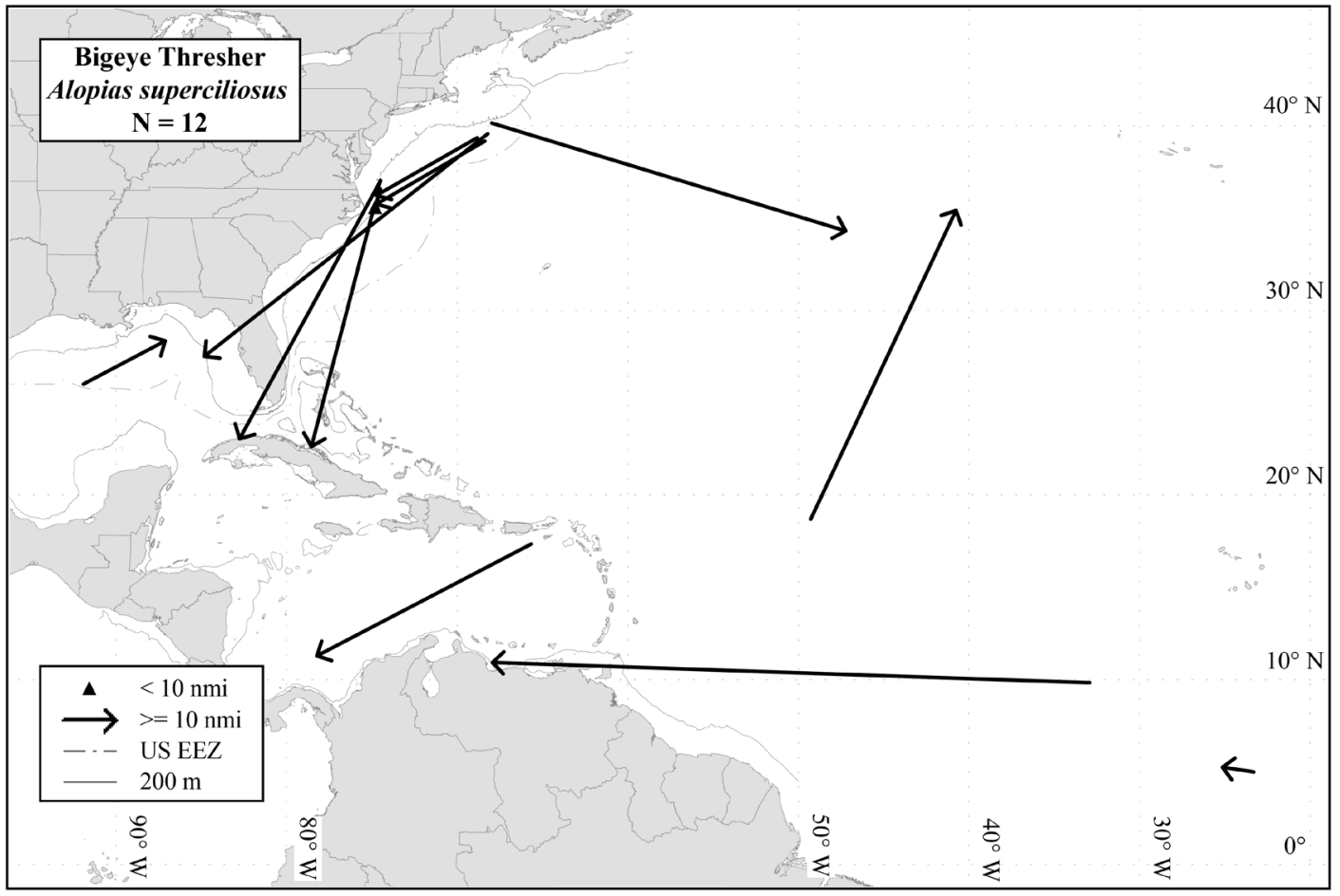

Figure 12a.-Distribution of recapture locations for the bigeye thresher, Alopias superciliosus, from the NMFS Cooperative Shark Tagging Program (1962-2013). 


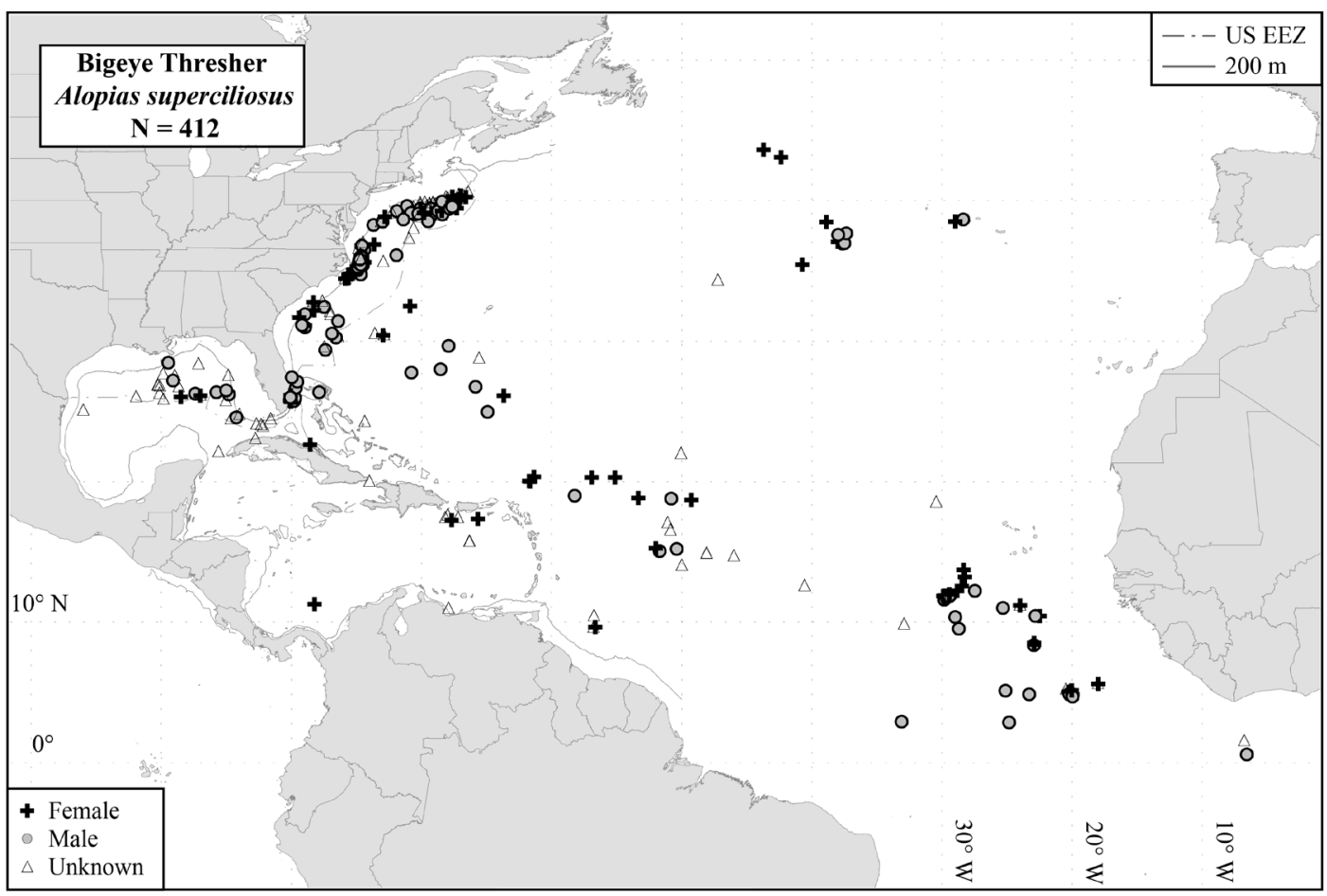

Figure 12b.-Distribution of mark/recapture locations for the bigeye thresher, Alopias superciliosus, from the NMFS Cooperative Shark Tagging Program (1962-2013).
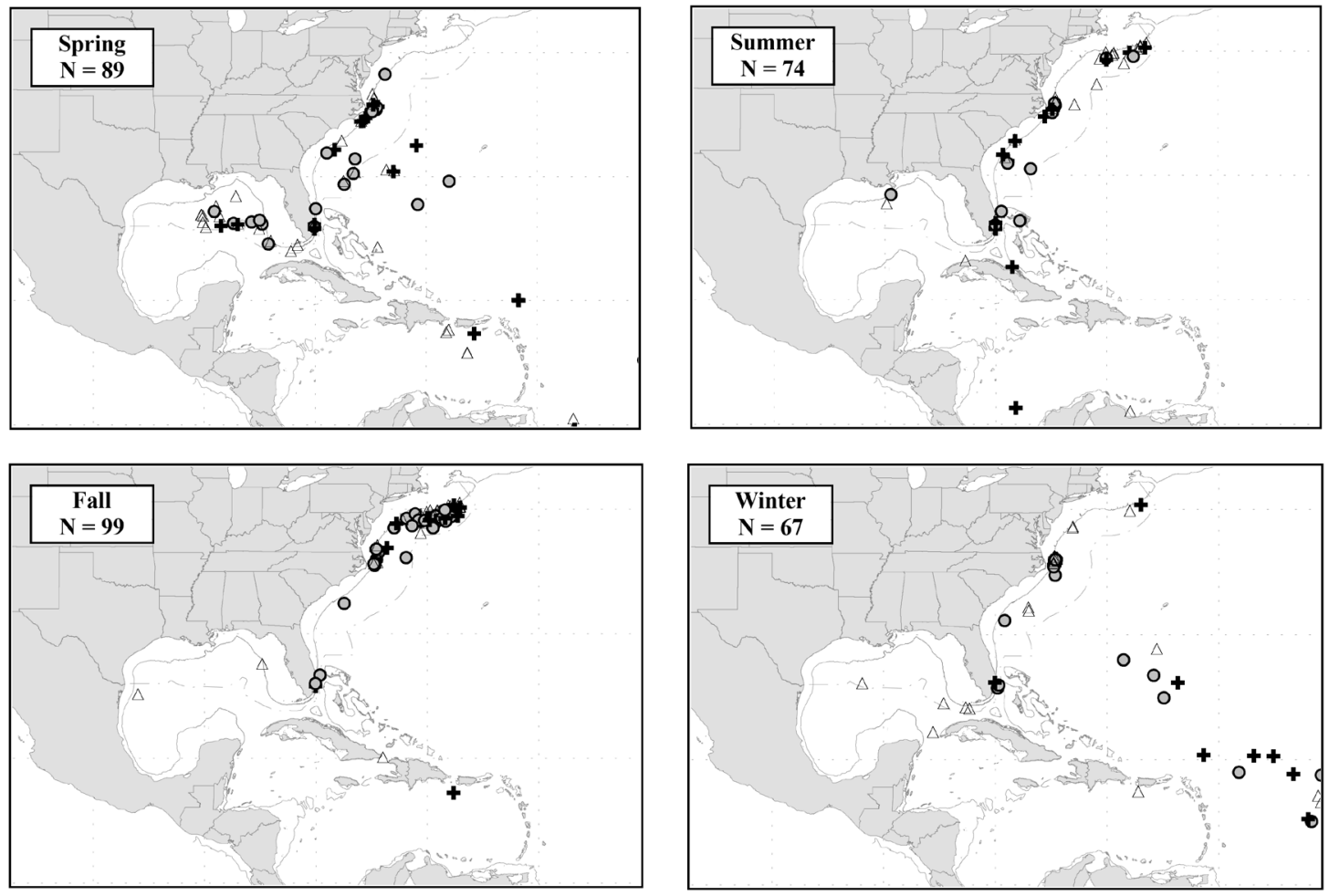

Figure 12c.- Seasonal distribution of mark/recapture locations in the western North Atlantic for the bigeye thresher, Alopias superciliosus, from the NMFS Cooperative Shark Tagging Program (1962-2013). 


\section{Bignose Shark}

\begin{tabular}{|c|c|c|c|c|c|c|c|}
\hline Sex & Tags & Recaptures & $\begin{array}{c}\text { Recapture rate } \\
(\%)\end{array}$ & $\begin{array}{l}\text { Mean distance } \\
\text { traveled (nmi) }\end{array}$ & $\begin{array}{l}\text { Maximum distance } \\
\text { traveled (nmi) }\end{array}$ & $\begin{array}{l}\text { Mean time at } \\
\text { liberty (years) }\end{array}$ & $\begin{array}{l}\text { Maximum time } \\
\text { at liberty (years) }\end{array}$ \\
\hline Male & 61 & 6 & 9.8 & 898.5 & 1,778 & 6.5 & 10.9 \\
\hline Female & 91 & 4 & 4.4 & $1,010.8$ & 1,484 & 5.5 & 11.2 \\
\hline Unknown & 23 & 1 & 4.3 & 768.0 & 768 & 2.0 & 2.0 \\
\hline Total & 175 & 11 & 6.3 & 927.5 & 1,778 & 5.7 & 11.2 \\
\hline
\end{tabular}

Yearly Summary of Tags, Recaptures, and Recapture Rate
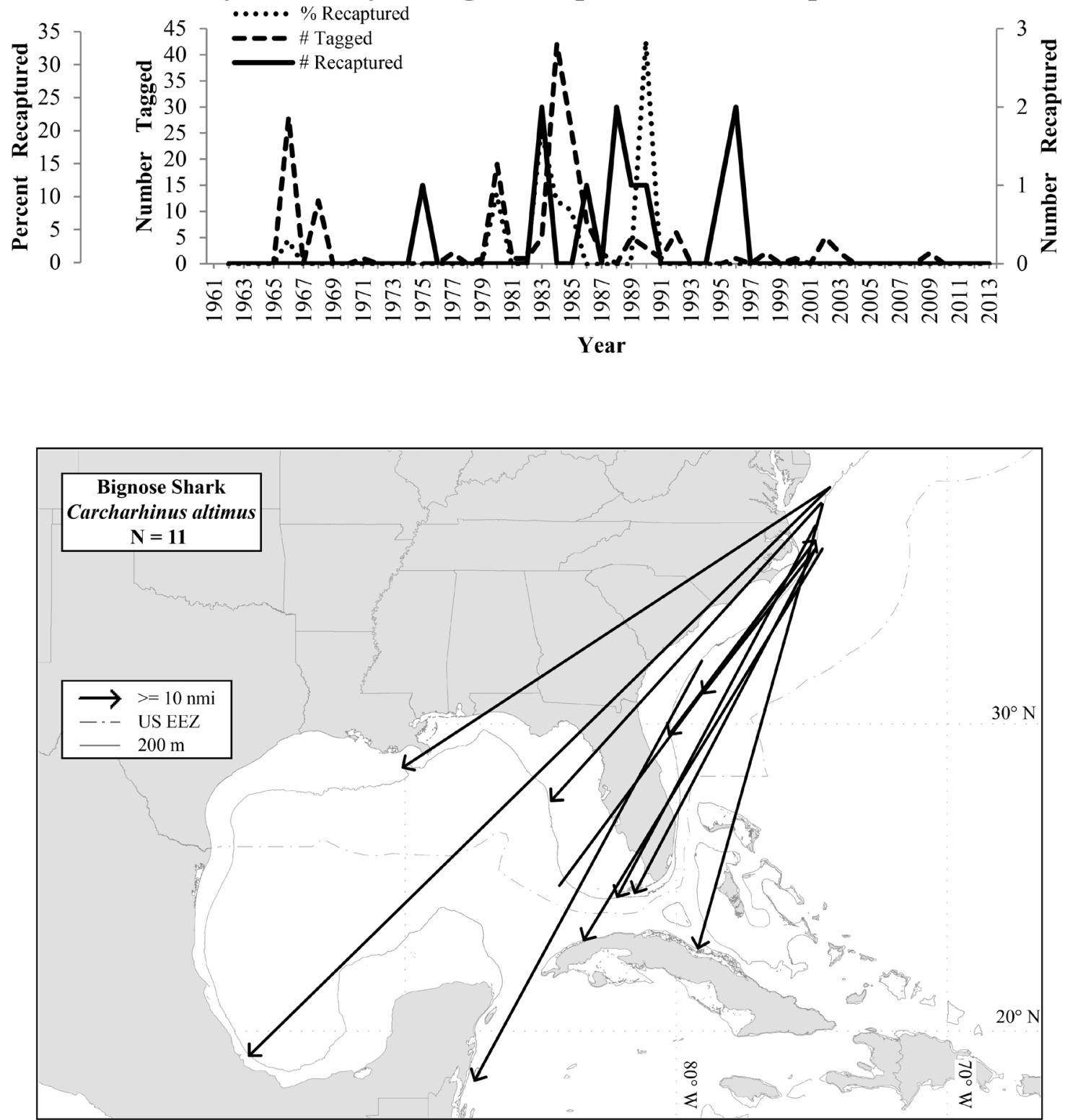

Figure 13a.-Distribution of recapture locations for the bignose shark, Carcharhinus altimus, from the NMFS Cooperative Shark Tagging Program (1962-2013). 


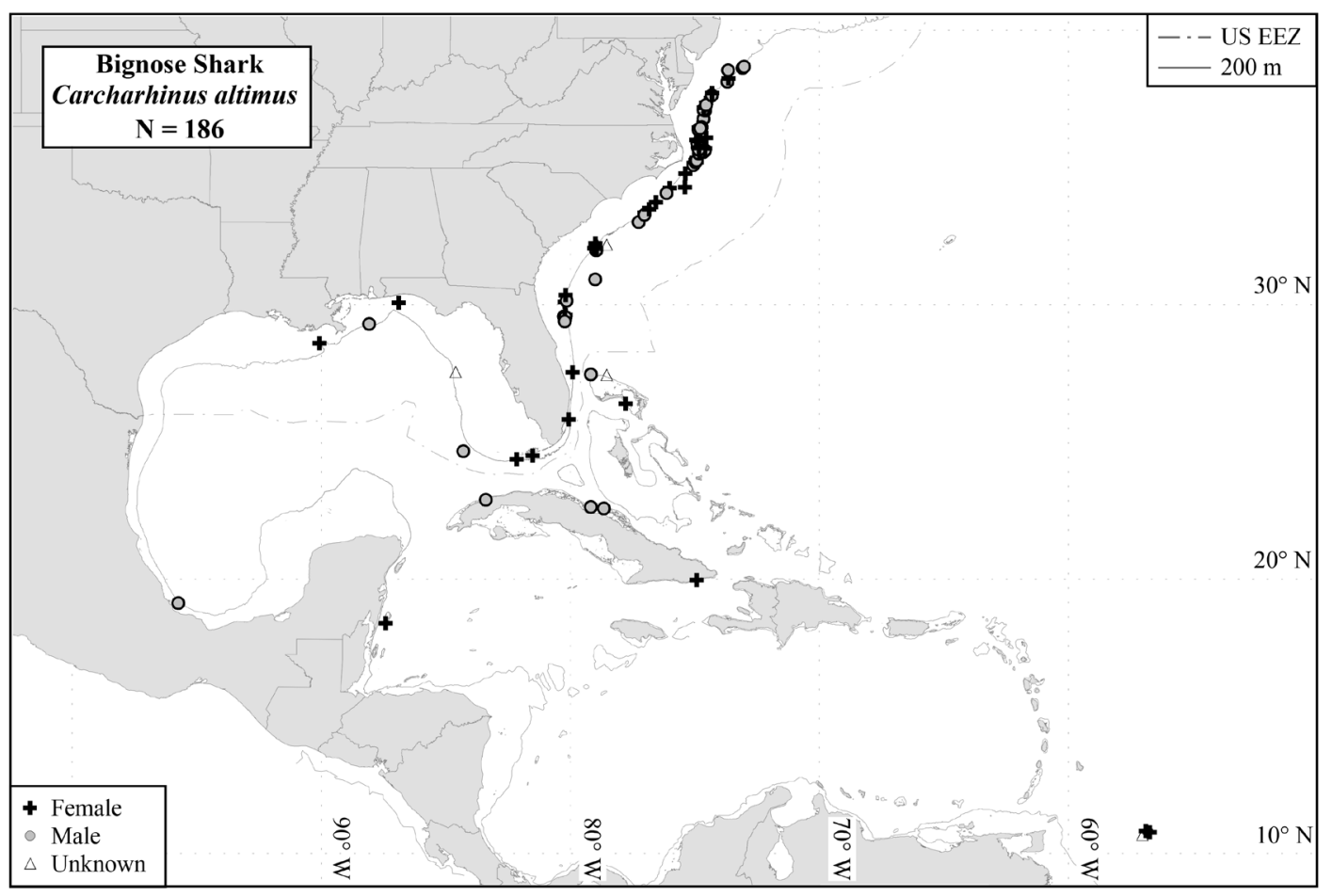

Figure 13b.-Distribution of mark/recapture locations for the bignose shark, Carcharhinus altimus, from the NMFS Cooperative Shark Tagging Program (1962-2013).
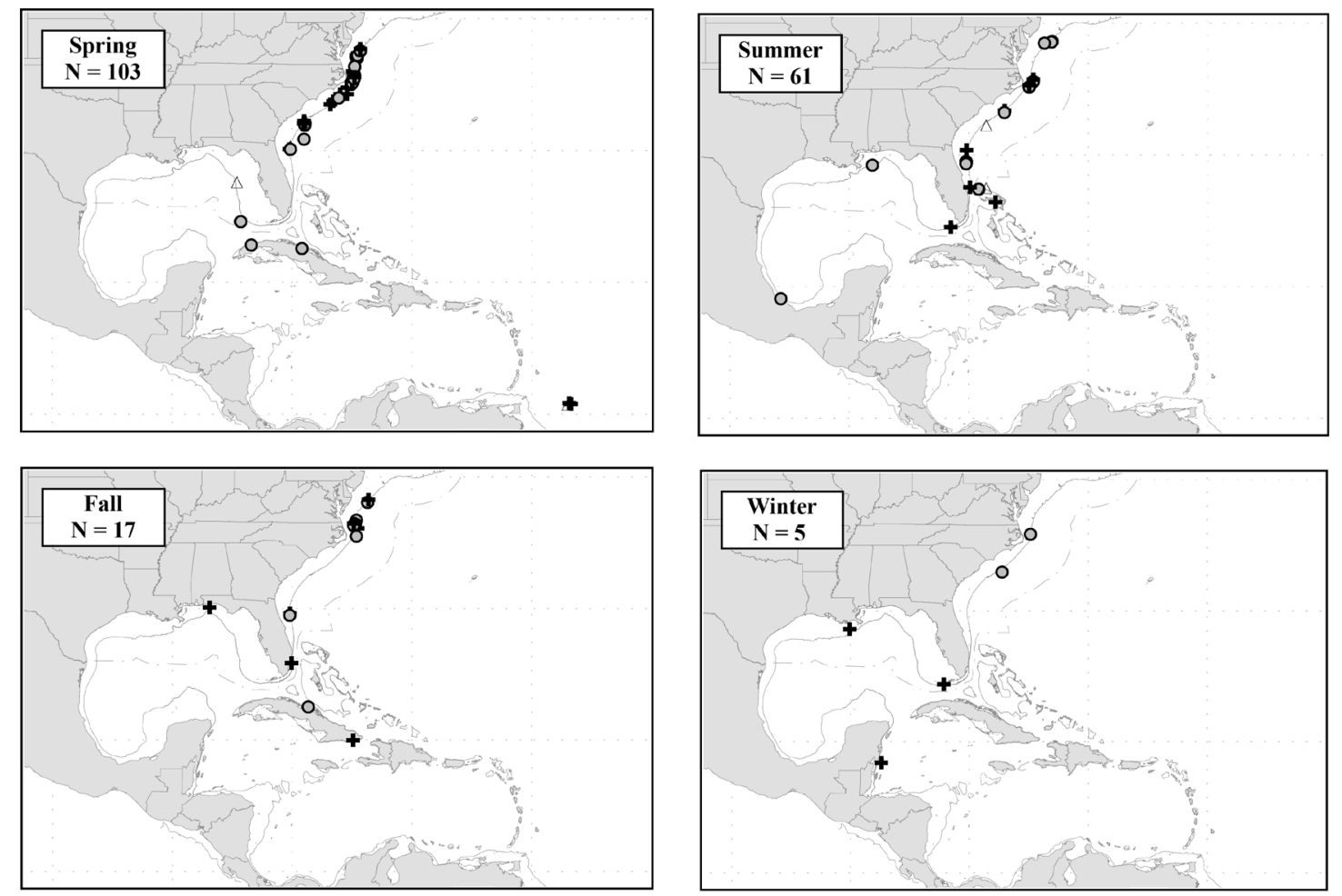

Figure 13c.- Seasonal distribution of mark/recapture locations for the bignose shark, Carcharhinus altimus, from the NMFS Cooperative Shark Tagging Program (1962-2013). 


\section{Blacknose Shark}

\begin{tabular}{lcccccc}
\hline Sex & Tags & Recaptures & $\begin{array}{c}\text { Recapture rate } \\
(\%)\end{array}$ & $\begin{array}{c}\text { Mean distance } \\
\text { traveled (nmi) }\end{array}$ & $\begin{array}{c}\text { Maximum distance } \\
\text { traveled (nmi) }\end{array}$ & $\begin{array}{c}\text { Mean time at } \\
\text { liberty (years) }\end{array}$ \\
\hline Male & 1,340 & 17 & 1.3 & 66.6 & $\begin{array}{c}\text { Maximum time } \\
\text { at liberty (years) }\end{array}$ \\
Female & 1,551 & 17 & 1.1 & 35.6 & 226 & 2.5 \\
Unknown & 67 & 1 & 1.5 & 8.0 & 8.1 & 3.1 \\
Total & 2,958 & 35 & 1.2 & 49.9 & 226 & 9.9 \\
\hline
\end{tabular}

Yearly Summary of Tags, Recaptures, and Recapture Rate

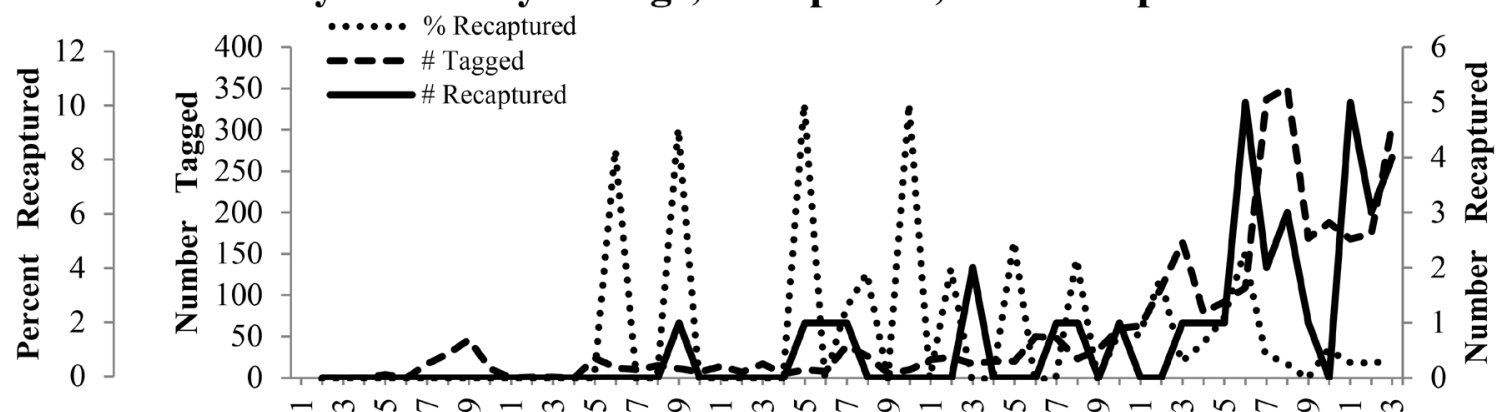

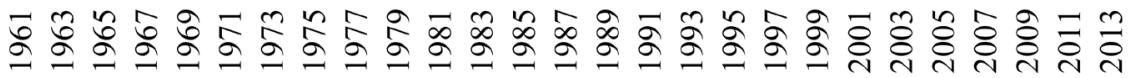

\section{Year}

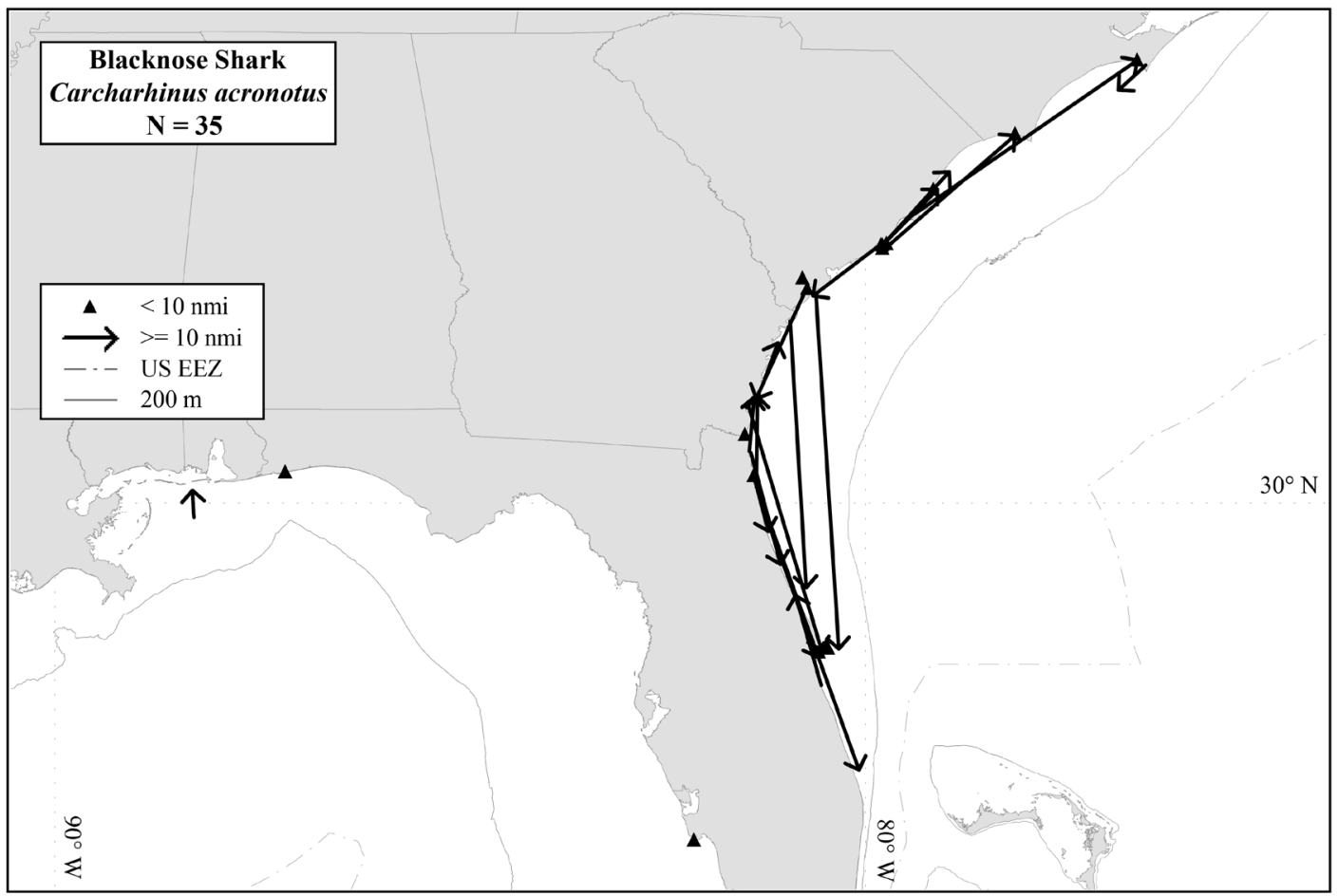

Figure 14a.-Distribution of recapture locations for the blacknose shark, Carcharhinus acronotus, from the NMFS Cooperative Shark Tagging Program (1962-2013). 


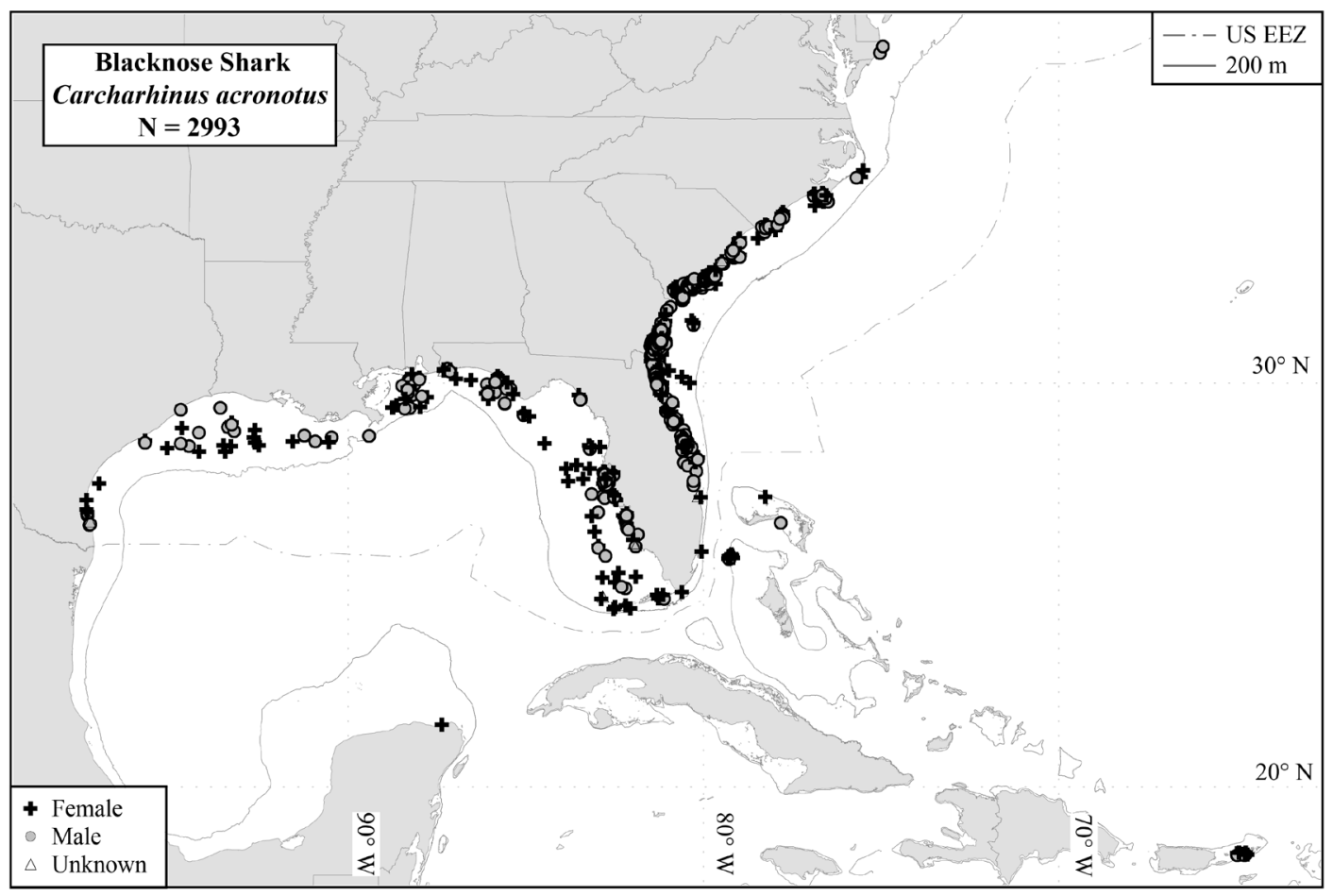

Figure 14b.-Distribution of mark/recapture locations for the blacknose shark, Carcharhinus acronotus, from the NMFS Cooperative Shark Tagging Program (1962-2013).
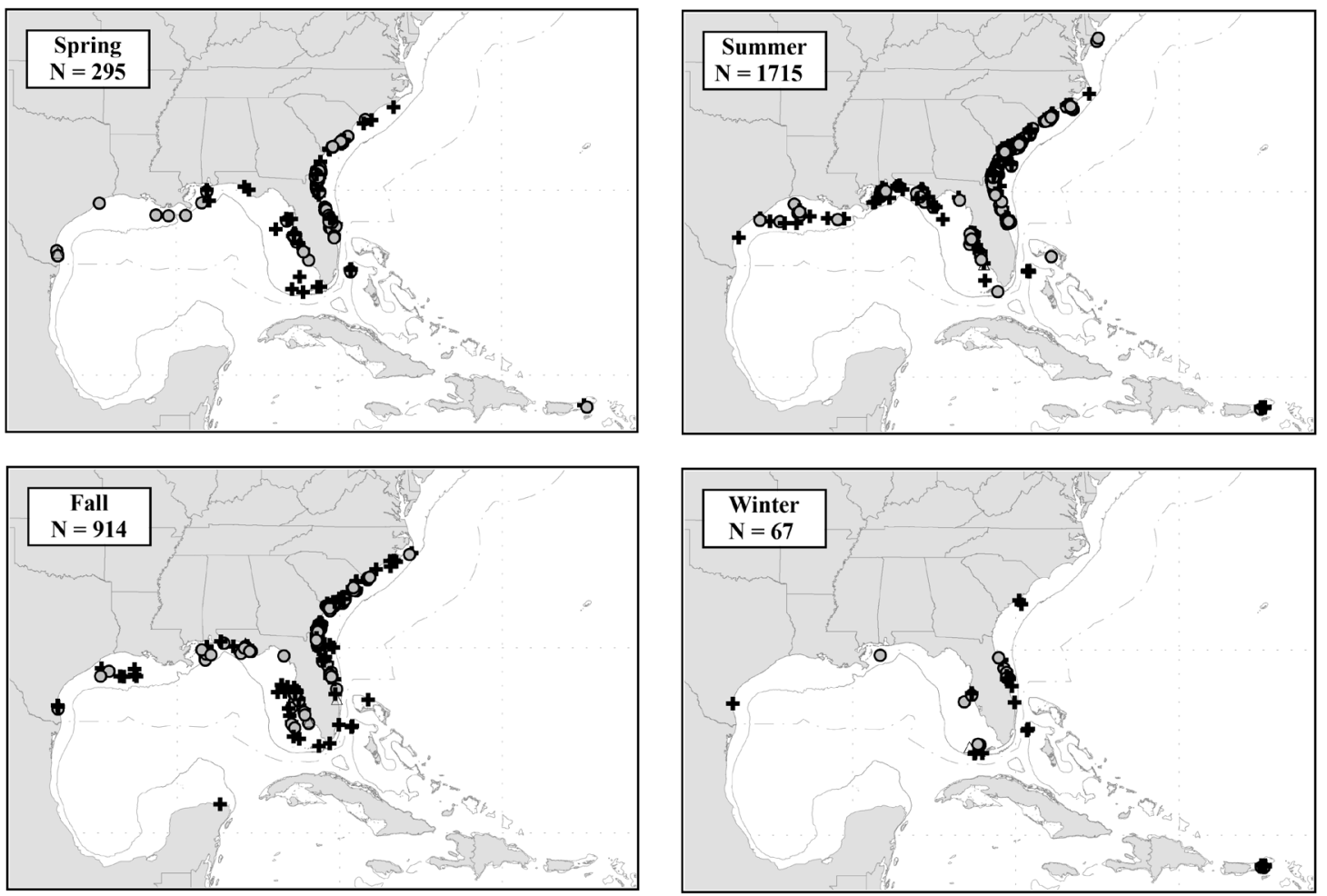

Figure 14c.- Seasonal distribution of mark/recapture locations for the blacknose shark, Carcharhinus acronotus, from the NMFS Cooperative Shark Tagging Program (1962-2013). 


\section{Blacktip Shark}

\begin{tabular}{|c|c|c|c|c|c|c|c|}
\hline Sex & Tags & Recaptures & $\begin{array}{c}\text { Recapture rate } \\
(\%)\end{array}$ & $\begin{array}{l}\text { Mean distance } \\
\text { traveled (nmi) }\end{array}$ & $\begin{array}{l}\text { Maximum distance } \\
\text { traveled (nmi) }\end{array}$ & $\begin{array}{l}\text { Mean time at } \\
\text { liberty (years) }\end{array}$ & $\begin{array}{l}\text { Maximum time } \\
\text { at liberty (years) }\end{array}$ \\
\hline Male & 3,699 & 101 & 2.7 & 112.8 & 1,183 & 0.9 & 9.3 \\
\hline Female & 5,681 & 133 & 2.3 & 116.2 & 632 & 0.8 & 7.8 \\
\hline Unknown & 913 & 35 & 3.8 & 81.0 & 607 & 0.9 & 5.9 \\
\hline Total & 10,293 & 269 & 2.6 & 110.9 & 1,183 & 0.8 & 9.3 \\
\hline
\end{tabular}

Yearly Summary of Tags, Recaptures, and Recapture Rate
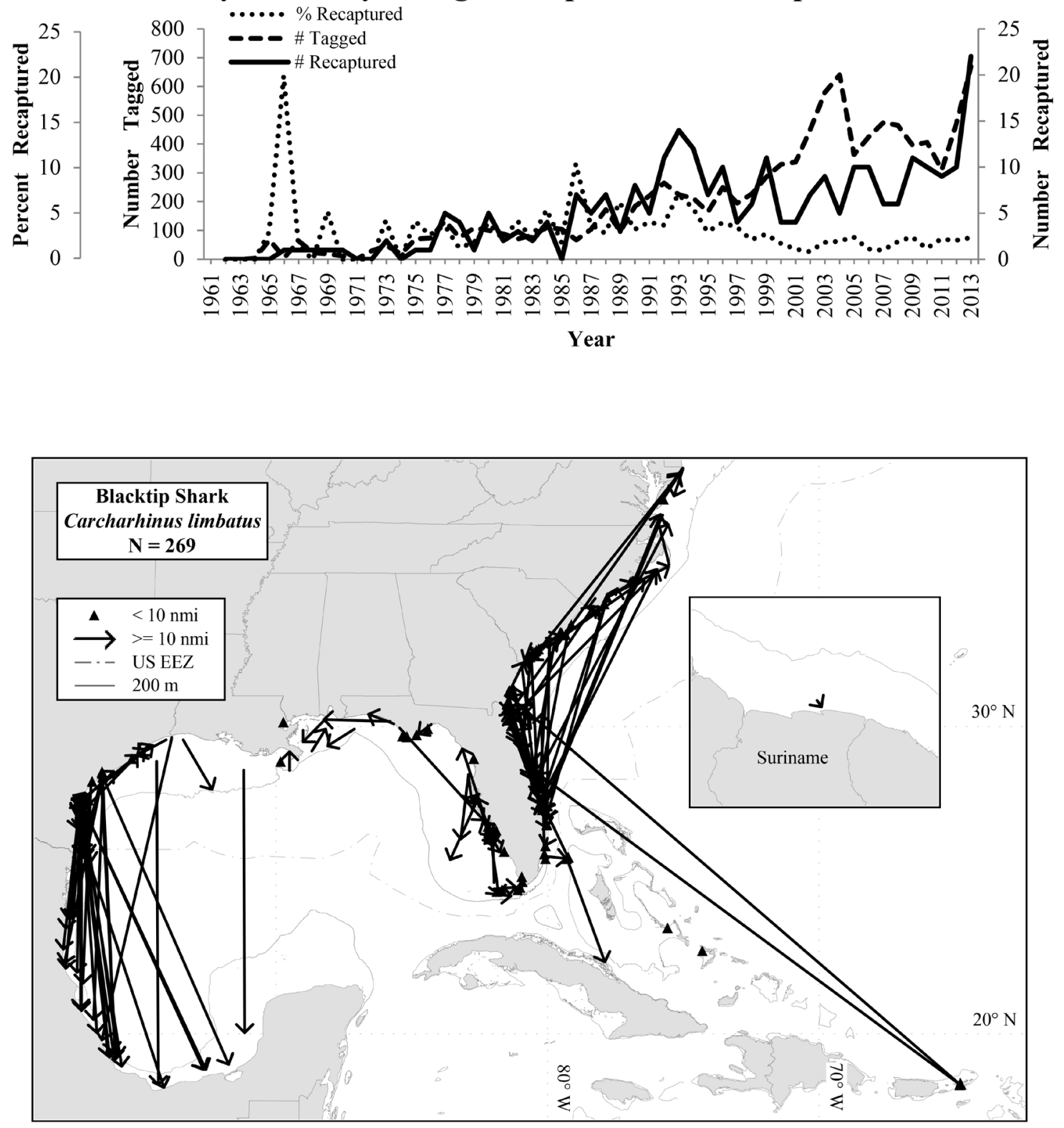

Figure 15a.-Distribution of recapture locations for the blacktip shark, Carcharhinus limbatus, from the NMFS Cooperative Shark Tagging Program (1962-2013). 


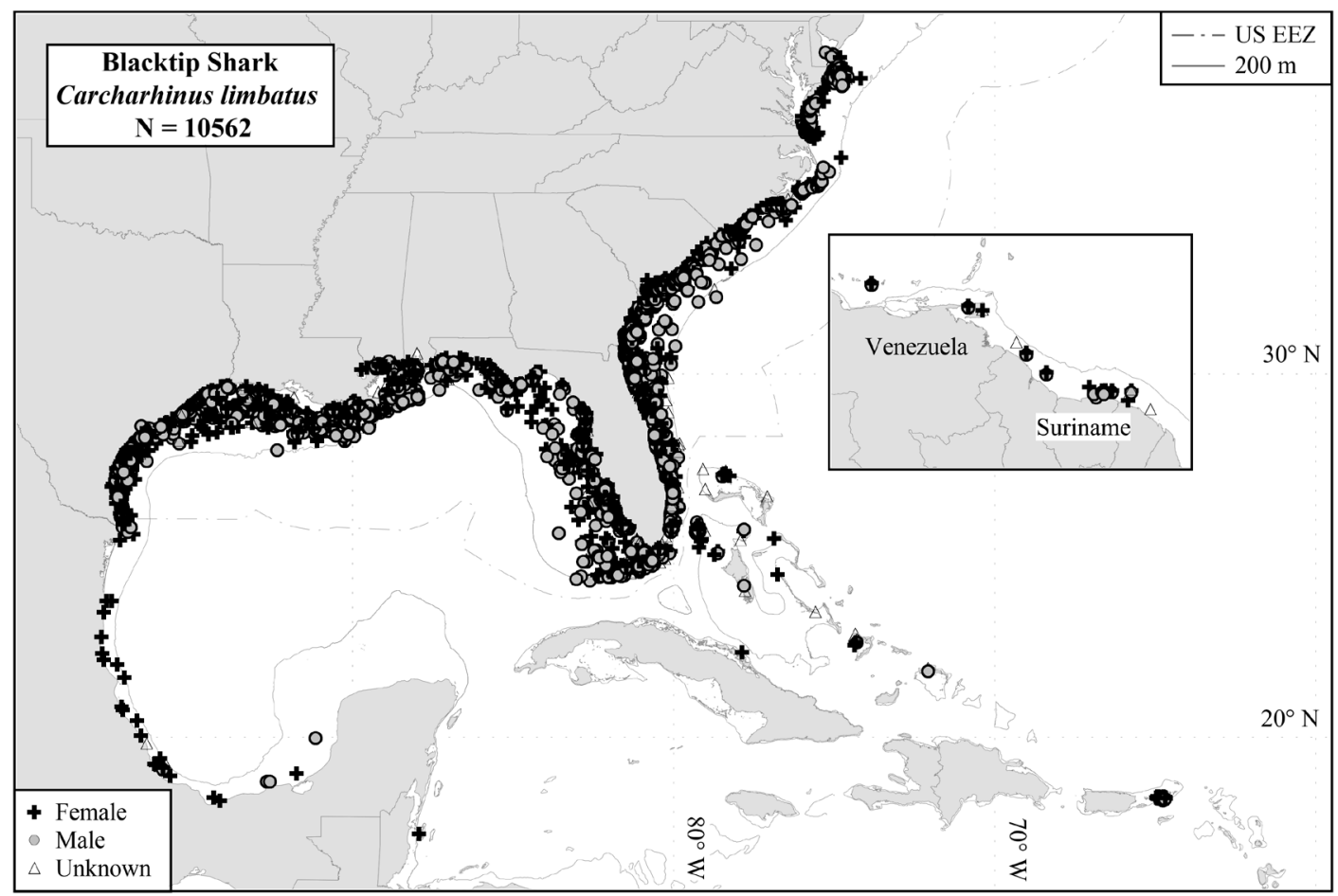

Figure 15b.-Distribution of mark/recapture locations for the blacktip shark, Carcharhinus limbatus, from the NMFS Cooperative Shark Tagging Program (1962-2013).
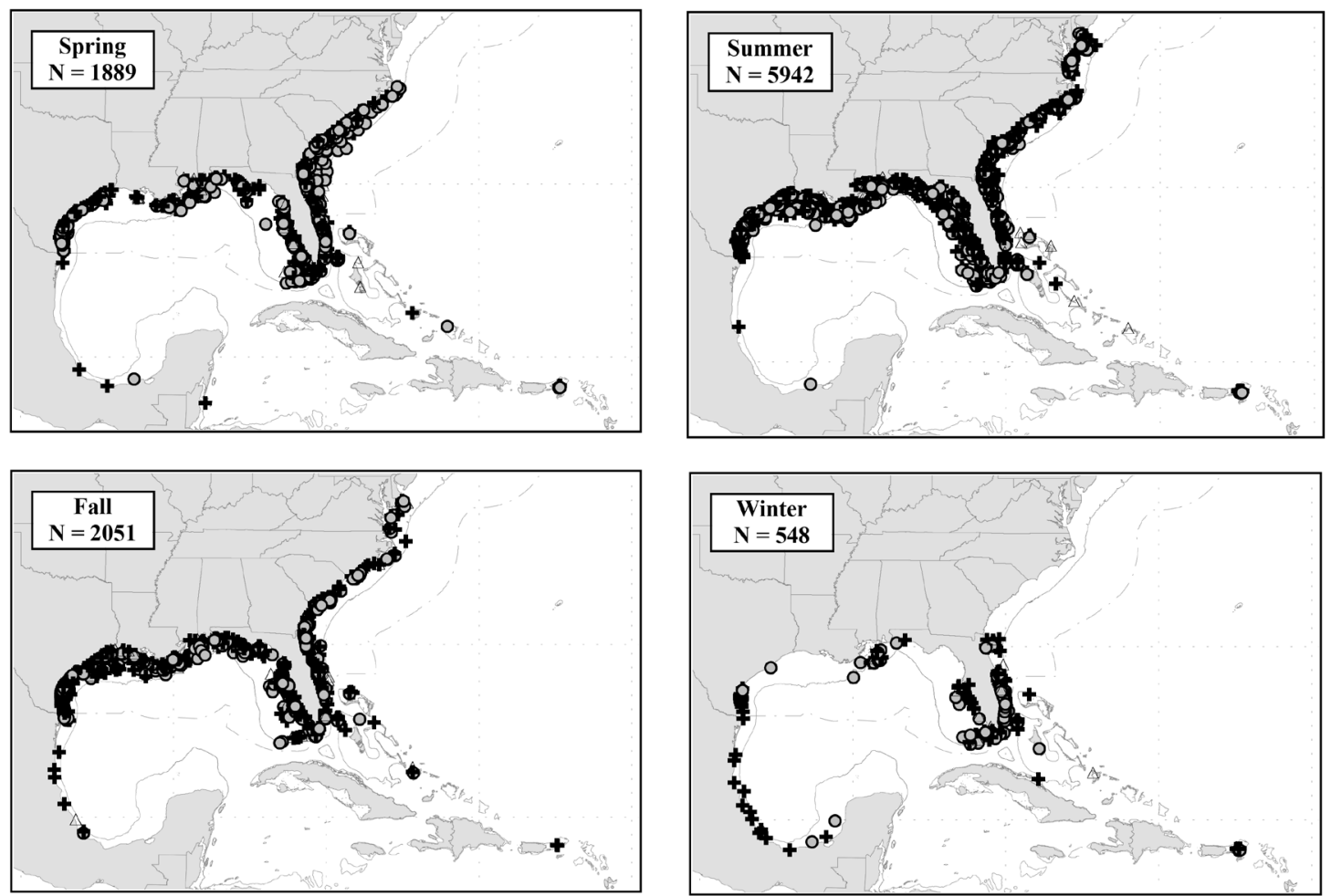

Figure 15c.- Seasonal distribution of mark/recapture locations in the western North Atlantic for the blacktip shark, Carcharhinus limbatus, from the NMFS Cooperative Shark Tagging Program (1962-2013). 


\section{Blue Shark}

\begin{tabular}{lcccccc}
\hline Sex & Tags & Recaptures & $\begin{array}{c}\text { Recapture rate } \\
(\%)\end{array}$ & $\begin{array}{c}\text { Mean distance } \\
\text { traveled (nmi) }\end{array}$ & $\begin{array}{c}\text { Maximum distance } \\
\text { traveled (nmi) }\end{array}$ & $\begin{array}{c}\text { Mean time at } \\
\text { liberty (years) }\end{array}$ \\
\hline Male & 48,107 & 3,914 & 8.1 & 608.8 & $\begin{array}{c}\text { Maximum time } \\
\text { at liberty (years) }\end{array}$ \\
Female & 37,055 & 2,603 & 7.0 & 491.6 & 3,997 & 1.3 \\
Unknown & 32,800 & 1,696 & 5.2 & 469.2 & 3,676 & 15.9 \\
Total & 117,962 & 8,213 & 7.0 & 543.2 & 3,740 & 1.9 \\
\hline
\end{tabular}

\section{Yearly Summary of Tags, Recaptures, and Recapture Rate}
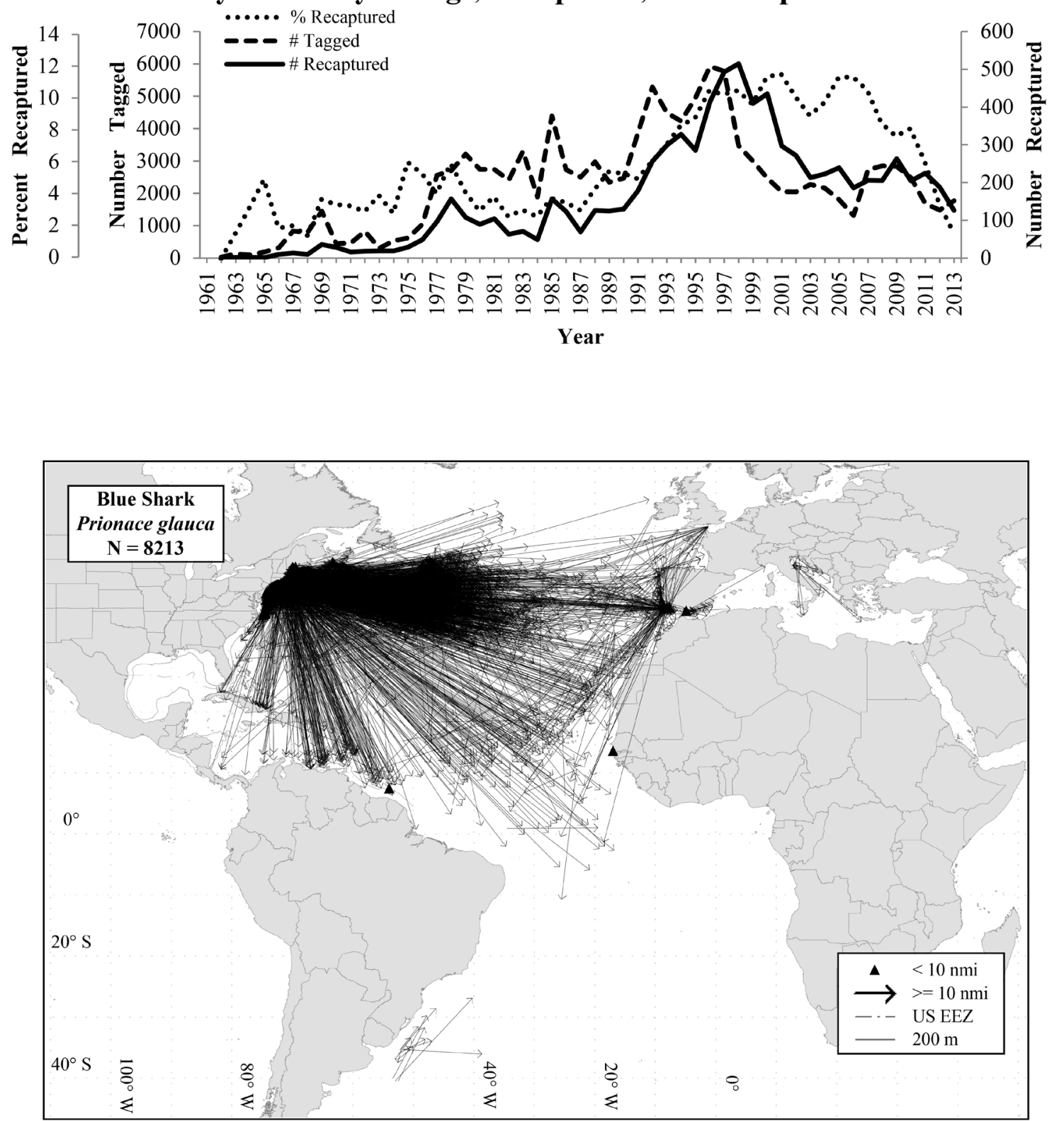

Figure 16a.-Distribution of recapture locations for the blue shark, Prionace glauca, from the NMFS Cooperative Shark Tagging Program (1962-2013). 


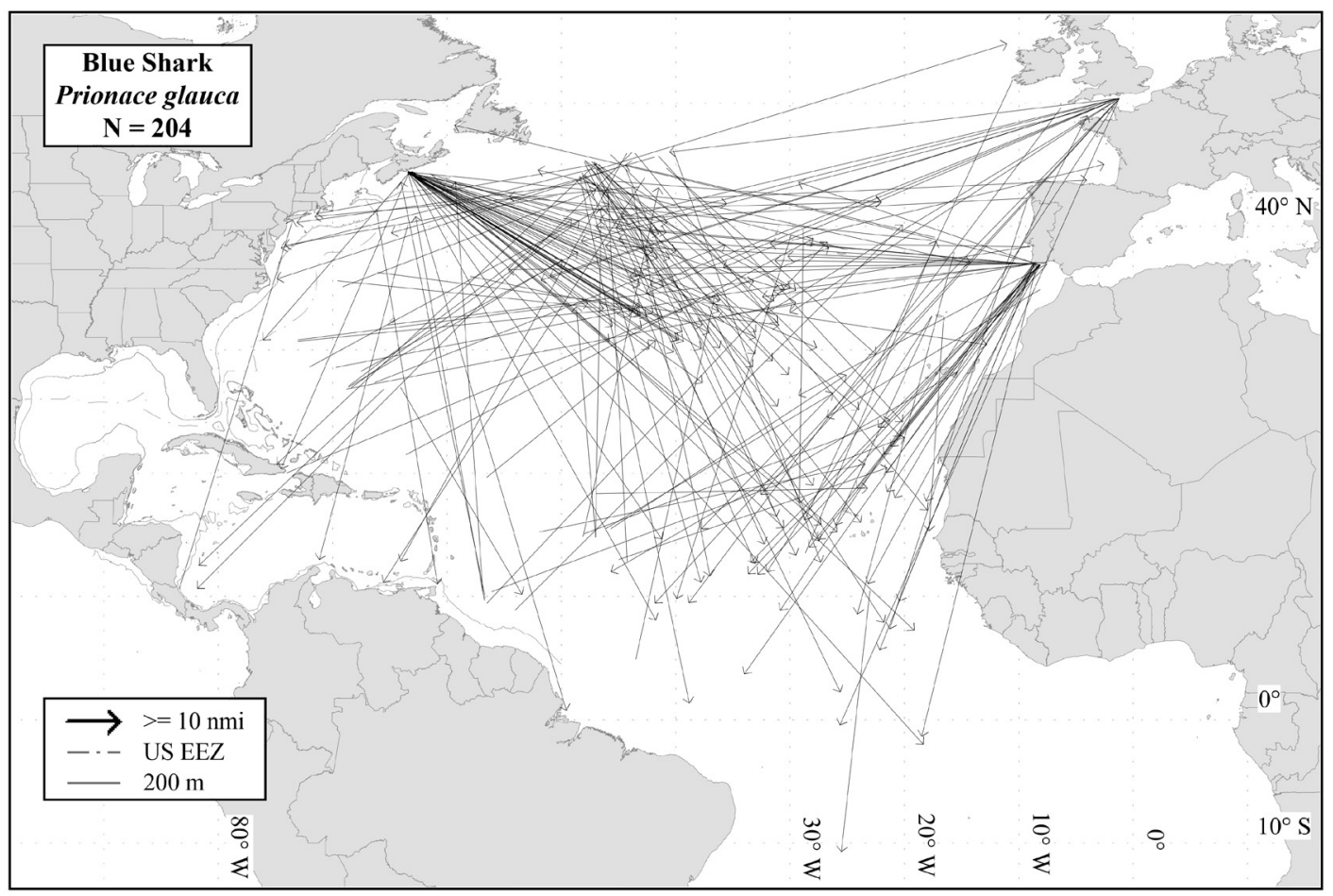

Figure 16b.-Distribution of recapture locations for the blue shark, Prionace glauca, tagged outside the U.S. EEZ and distance traveled greater than 1,000 nmi, from the NMFS Cooperative Shark Tagging Program (1962-2013).

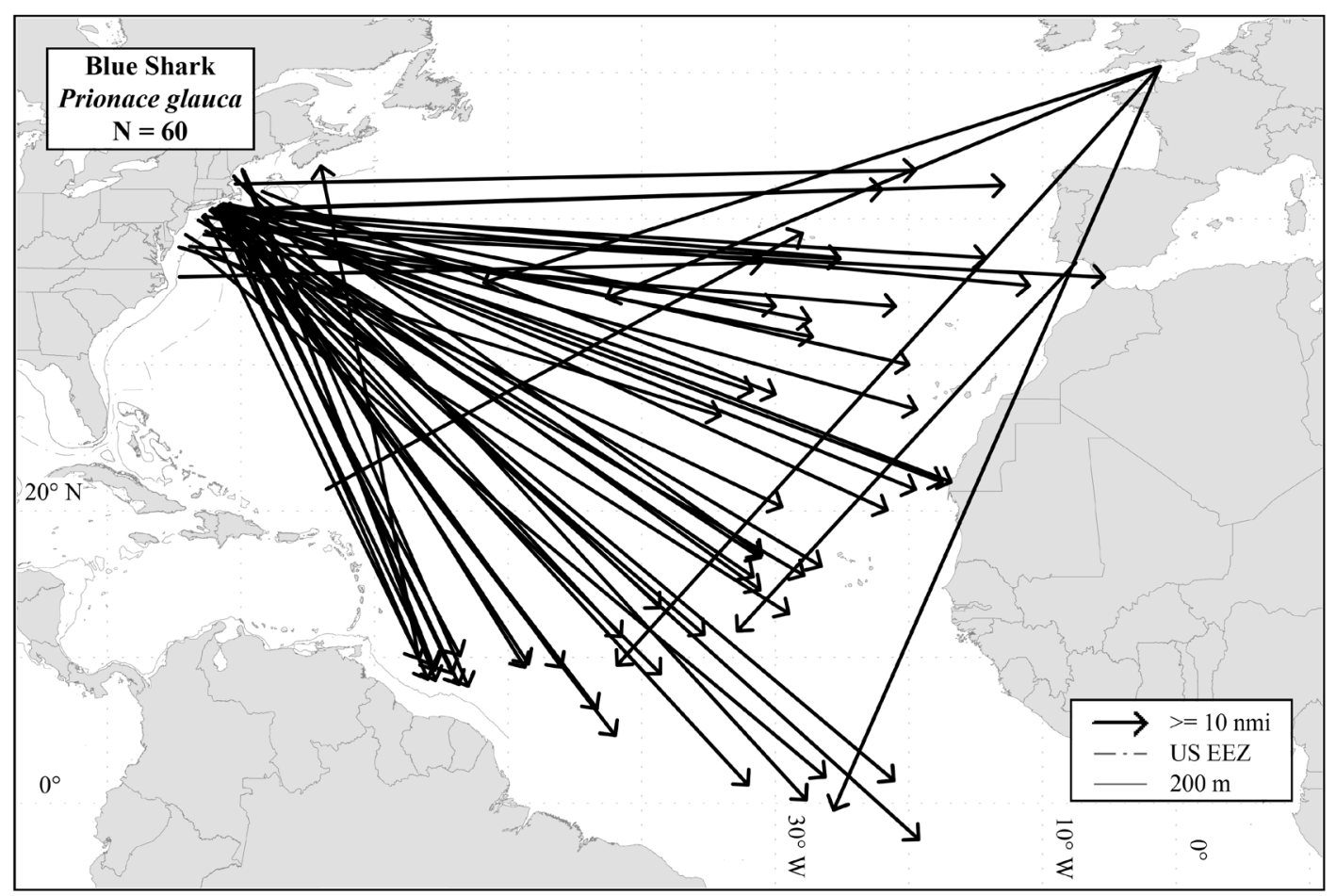

Figure 16c.-Long distance recaptures (> $2000 \mathrm{nmi}$ ) for the blue shark, Prionace glauca, at liberty for less than one year from the NMFS Cooperative Shark Tagging Program (1962-2013). 


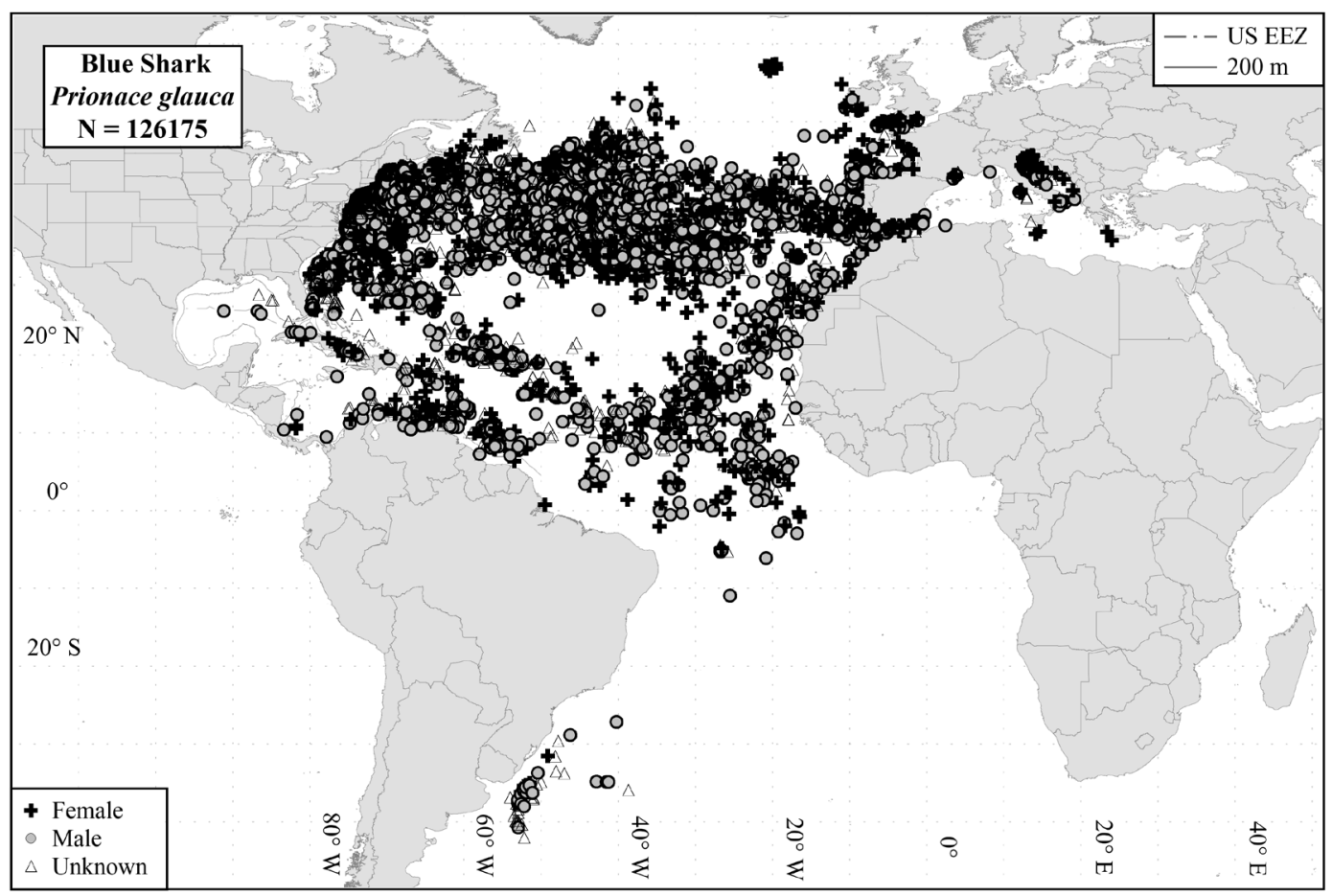

Figure 16d.-Distribution of mark/recapture locations for the blue shark, Prionace glauca, from the NMFS Cooperative Shark Tagging Program (1962-2013).
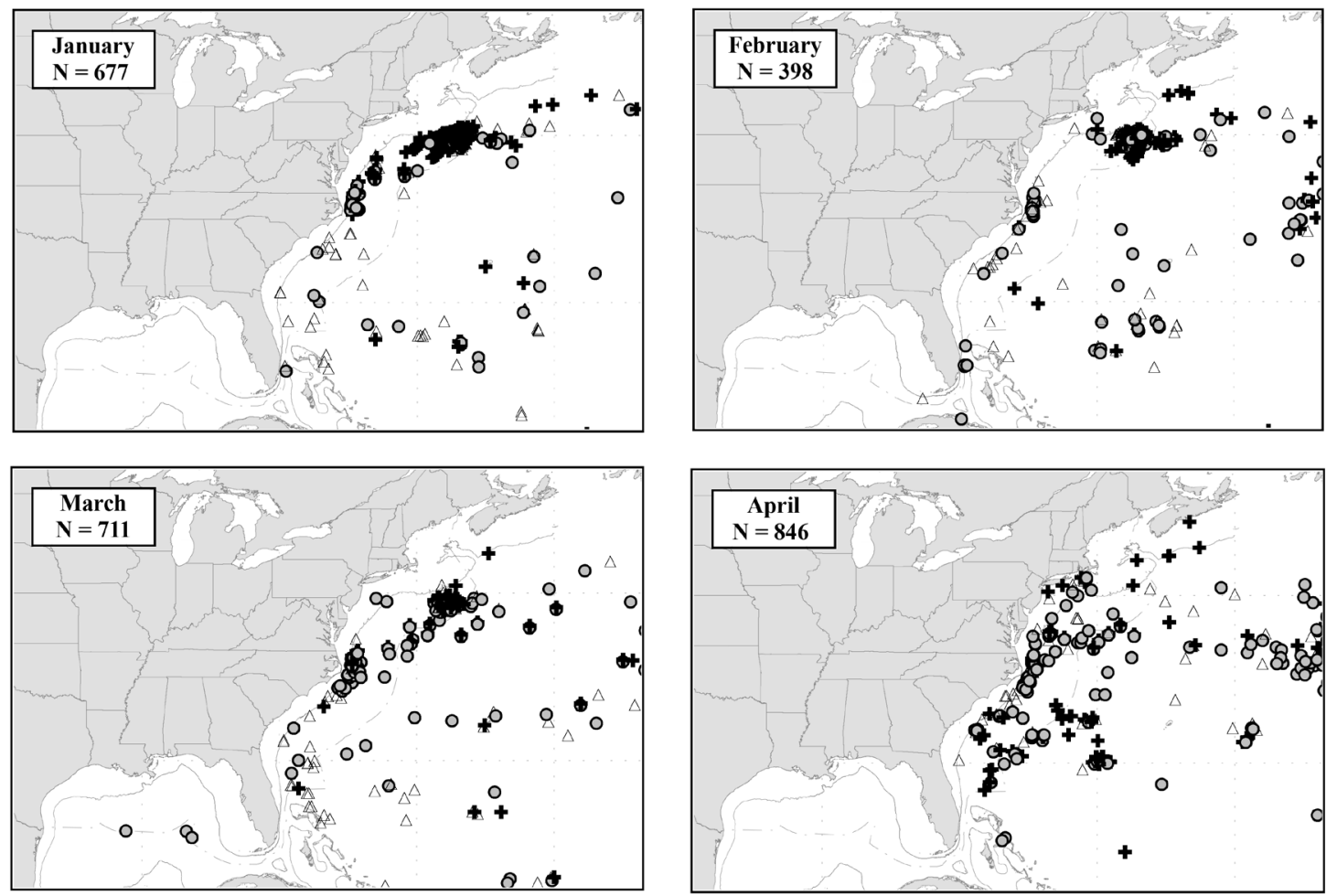

Figure 16e.-Monthly seasonal distribution of mark/recapture locations in the western North Atlantic for the blue shark, Prionace glauca, from the NMFS Cooperative Shark Tagging Program (1962-2013). 

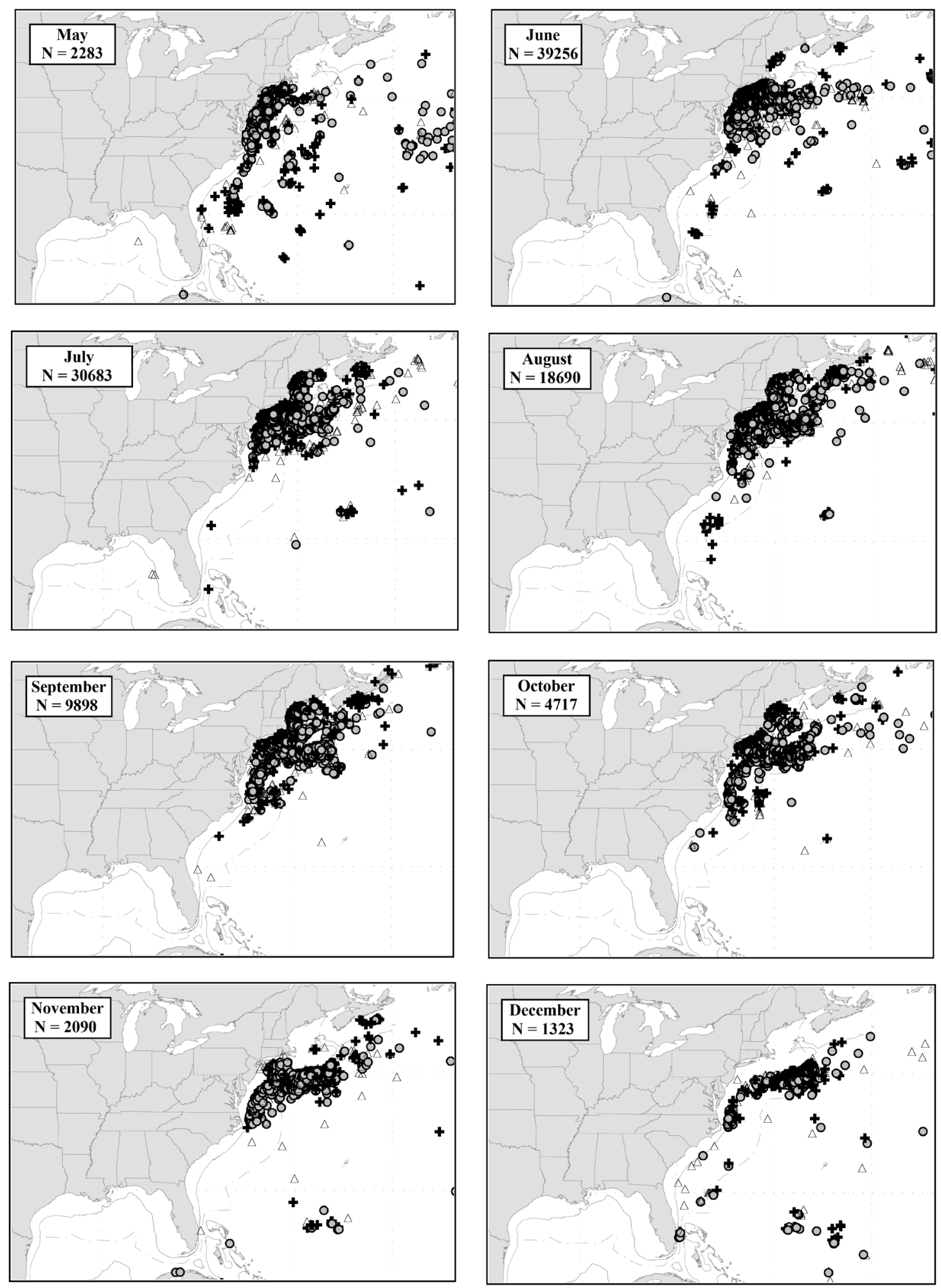

Figure 16e.-Continued 


\section{Bonnethead}

\begin{tabular}{lccccrr}
\hline Sex & Tags & Recaptures & $\begin{array}{c}\text { Recapture rate } \\
(\%)\end{array}$ & $\begin{array}{c}\text { Mean distance } \\
\text { traveled (nmi) }\end{array}$ & $\begin{array}{c}\text { Maximum distance } \\
\text { traveled (nmi) }\end{array}$ & $\begin{array}{c}\text { Mean time at } \\
\text { liberty (years) }\end{array}$ \\
\hline Male & 1,118 & 15 & 1.3 & 3.0 & $\begin{array}{c}\text { Maximum time } \\
\text { at liberty (years) }\end{array}$ \\
Female & 3,751 & 199 & 5.3 & 9.8 & 22 & 0.4 \\
Unknown & 188 & 7 & 3.7 & 14.0 & 302 & 0.9 \\
Total & 5,057 & 221 & 4.4 & 9.5 & 30 & 0.1 \\
\hline
\end{tabular}

\section{Yearly Summary of Tags, Recaptures, and Recapture Rate}

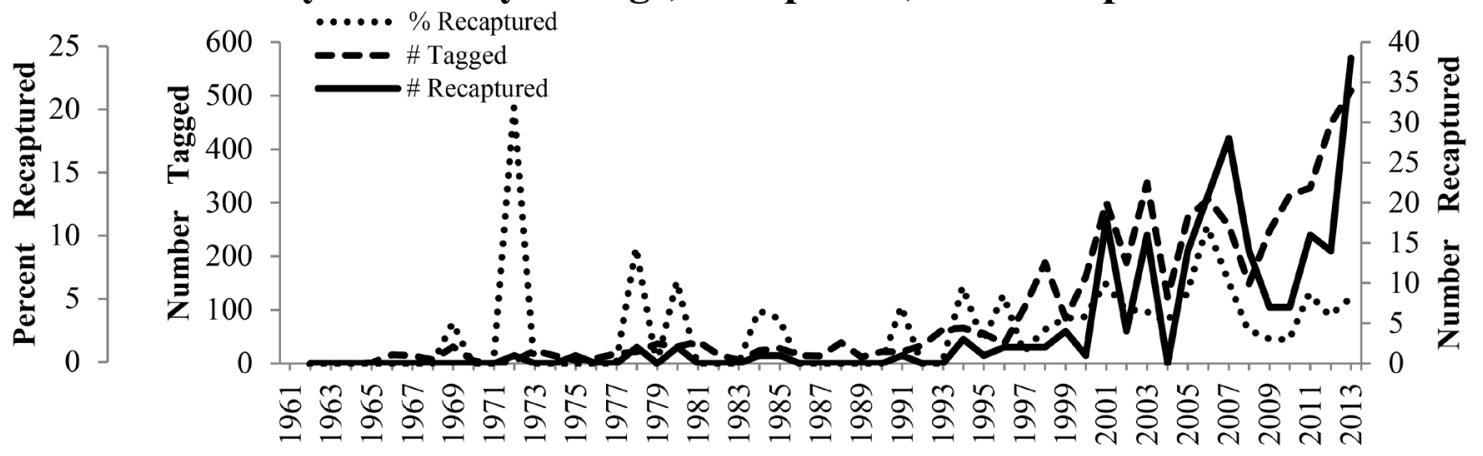

Year

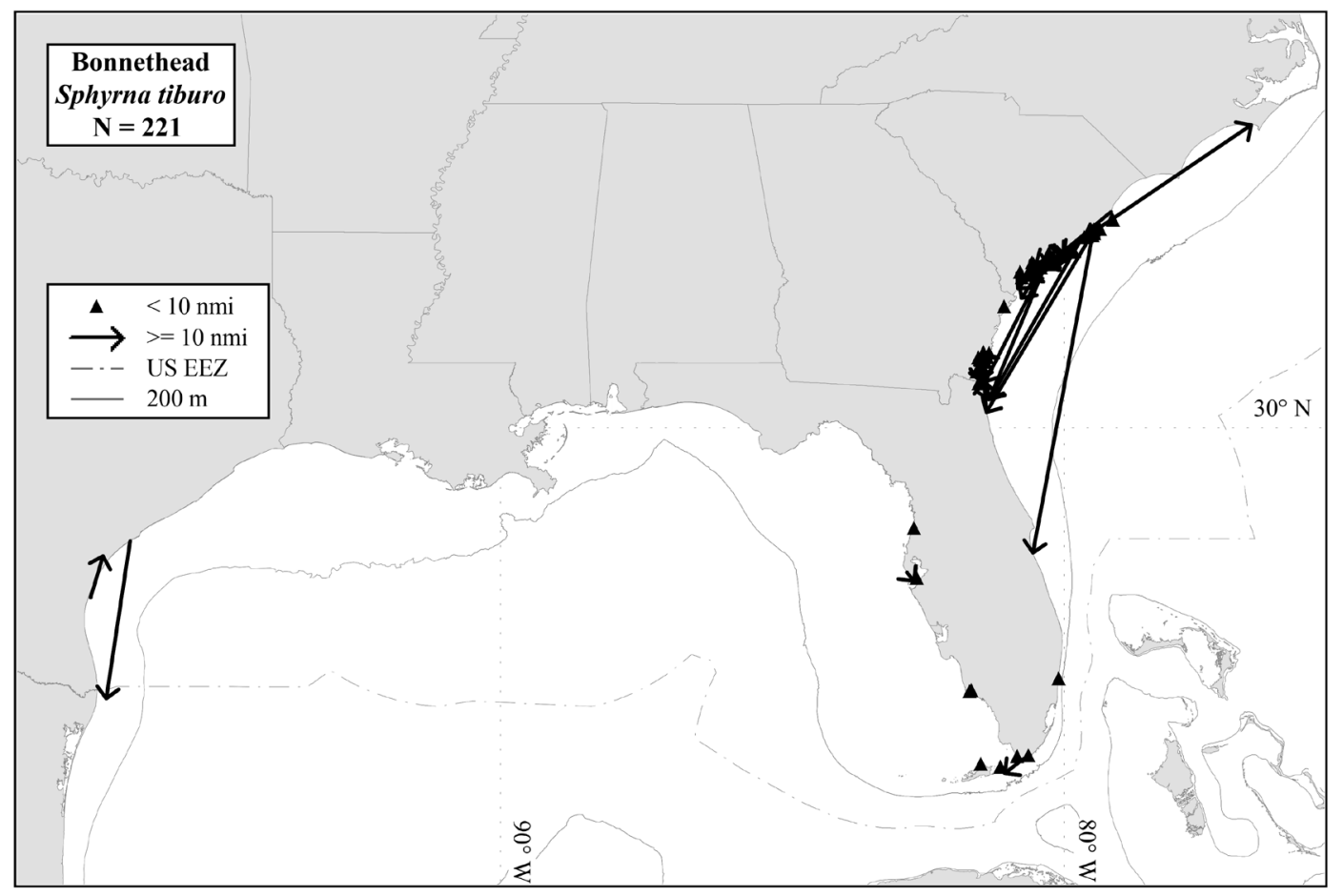

Figure 17a.-Distribution of recapture locations for the bonnethead, Sphyrna tiburo, from the NMFS Cooperative Shark Tagging Program (1962-2013). 


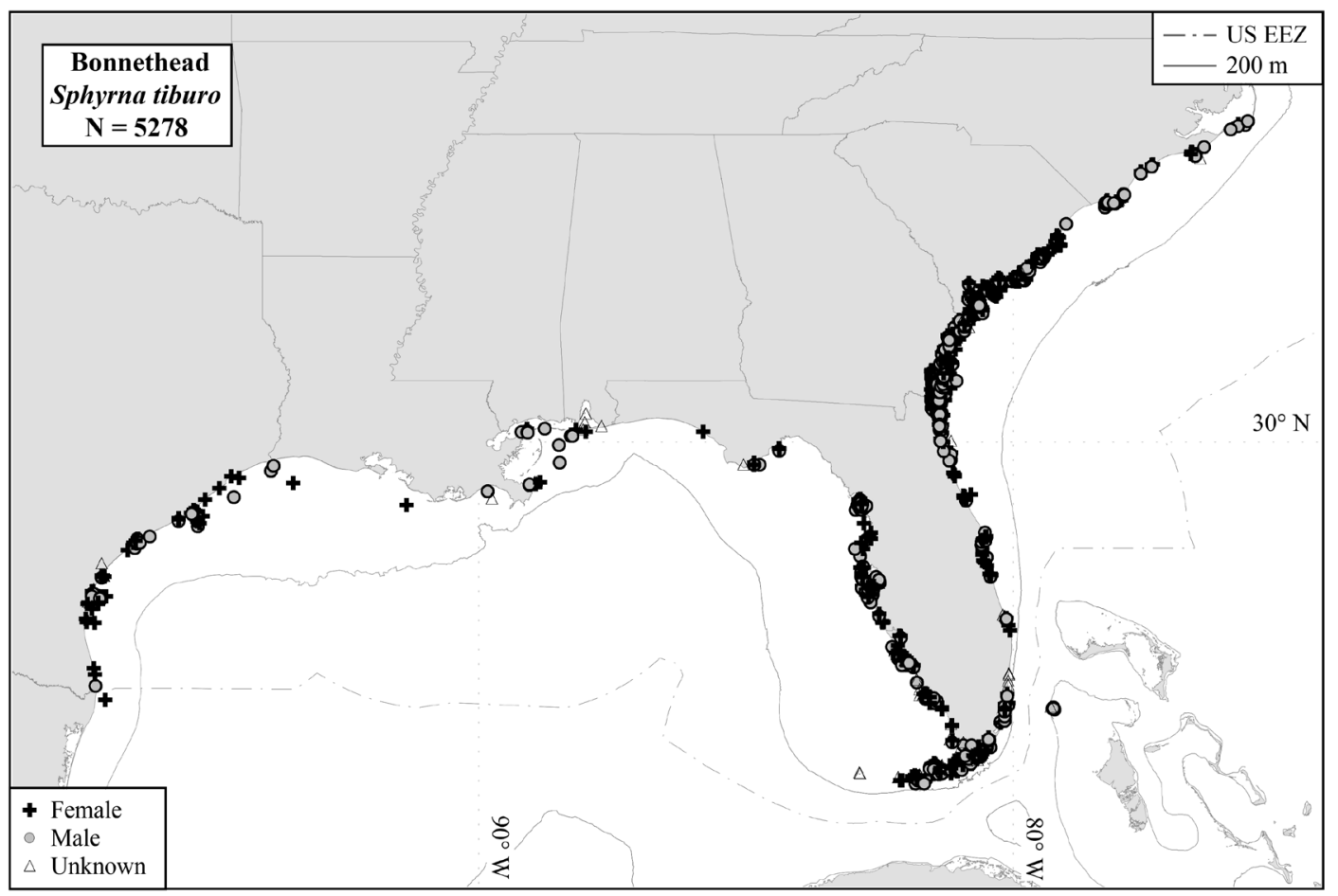

Figure 17b.-Distribution of mark/recapture locations for the bonnethead, Sphyrna tiburo, from the NMFS Cooperative Shark Tagging Program (1962-2013).
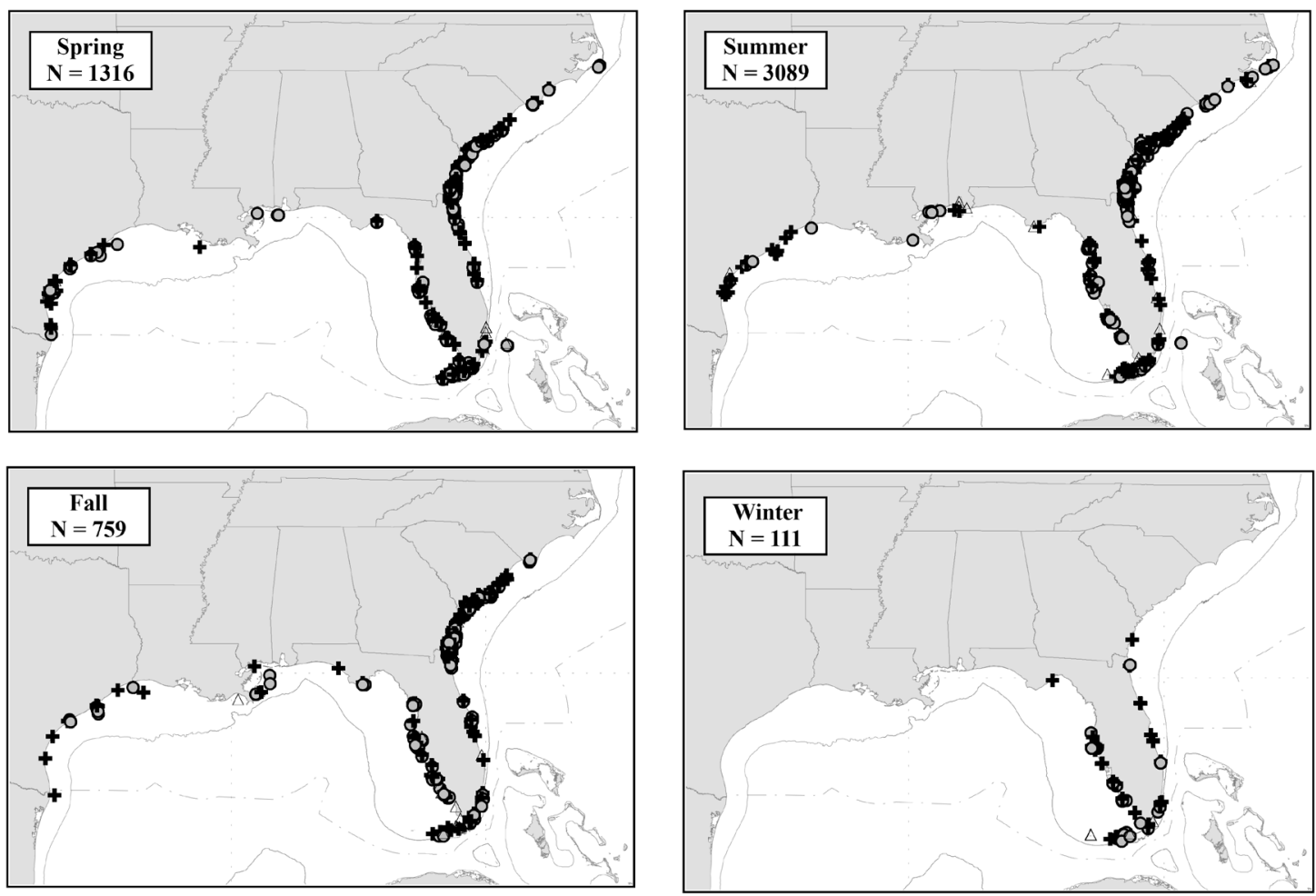

Figure 17c.- Seasonal distribution of mark/recapture locations for the bonnethead, Sphyrna tiburo, from the NMFS Cooperative Shark Tagging Program (1962-2013). 


\section{Bull Shark}

\begin{tabular}{|c|c|c|c|c|c|c|c|}
\hline Sex & Tags & Recaptures & $\begin{array}{c}\text { Recapture rate } \\
(\%)\end{array}$ & $\begin{array}{l}\text { Mean distance } \\
\text { traveled (nmi) }\end{array}$ & $\begin{array}{l}\text { Maximum distance } \\
\text { traveled (nmi) }\end{array}$ & $\begin{array}{l}\text { Mean time at } \\
\text { liberty (years) }\end{array}$ & $\begin{array}{l}\text { Maximum time } \\
\text { at liberty (years) }\end{array}$ \\
\hline Male & 702 & 11 & 1.6 & 201.6 & 428 & 1.2 & 6.7 \\
\hline Female & 1,167 & 20 & 1.7 & 125.4 & 628 & 0.8 & 4.8 \\
\hline Unknown & 260 & 5 & 1.9 & 122.5 & 349 & 1.0 & 1.9 \\
\hline Total & 2,129 & 36 & 1.7 & 149.0 & 628 & 1.0 & 6.7 \\
\hline
\end{tabular}

Yearly Summary of Tags, Recaptures, and Recapture Rate

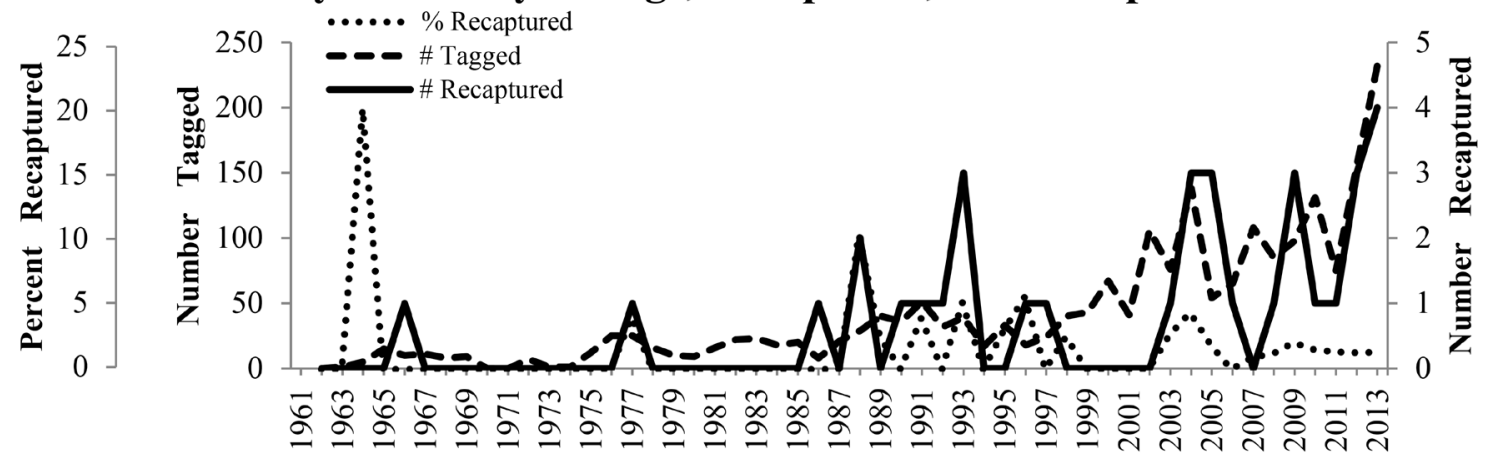

Year

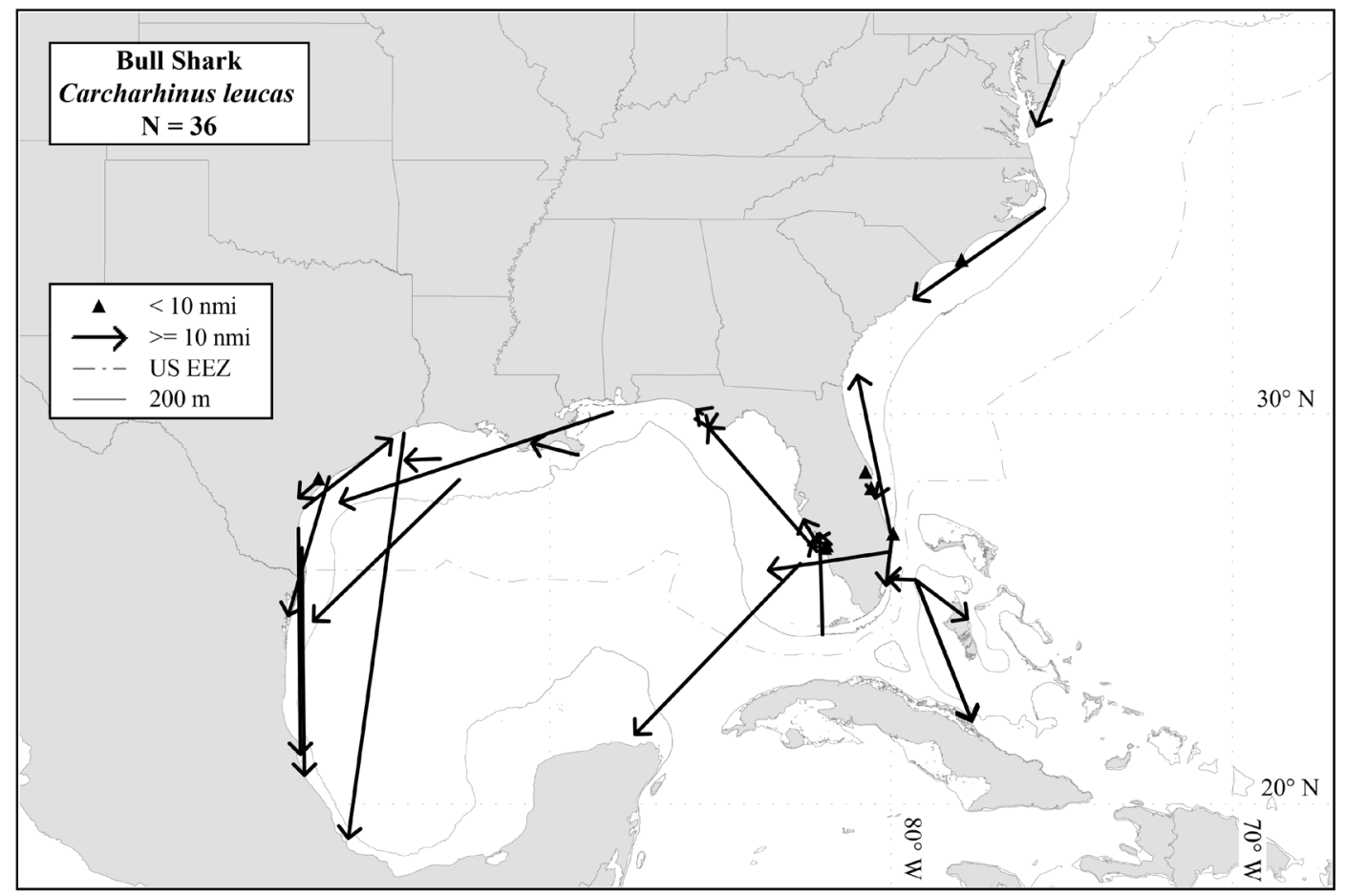

Figure 18a.-Distribution of recapture locations for the bull shark, Carcharhinus leucas, from the NMFS Cooperative Shark Tagging Program (1962-2013). 


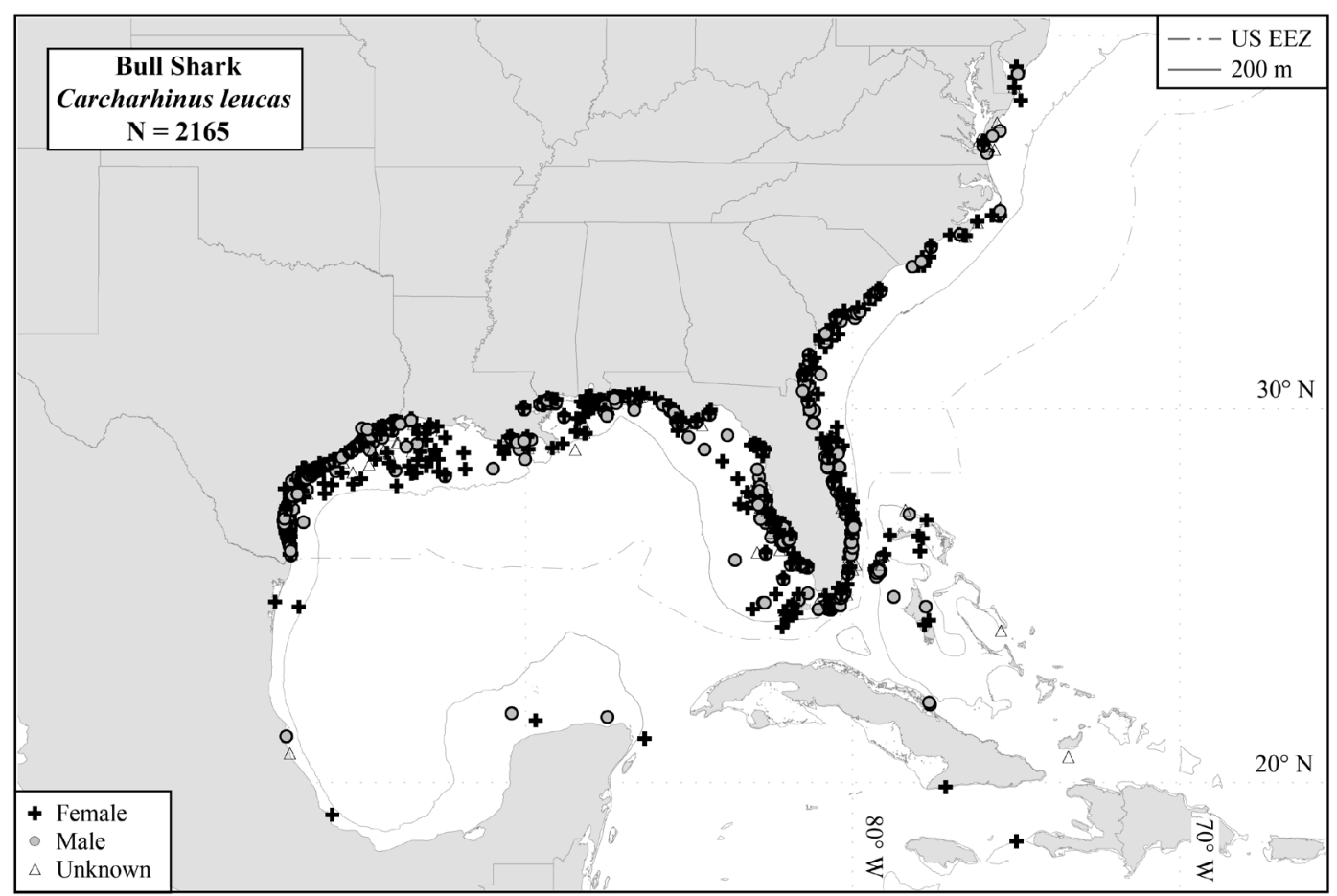

Figure 18b.-Distribution of mark/recapture locations for the bull shark, Carcharhinus leucas, from the NMFS Cooperative Shark Tagging Program (1962-2013)
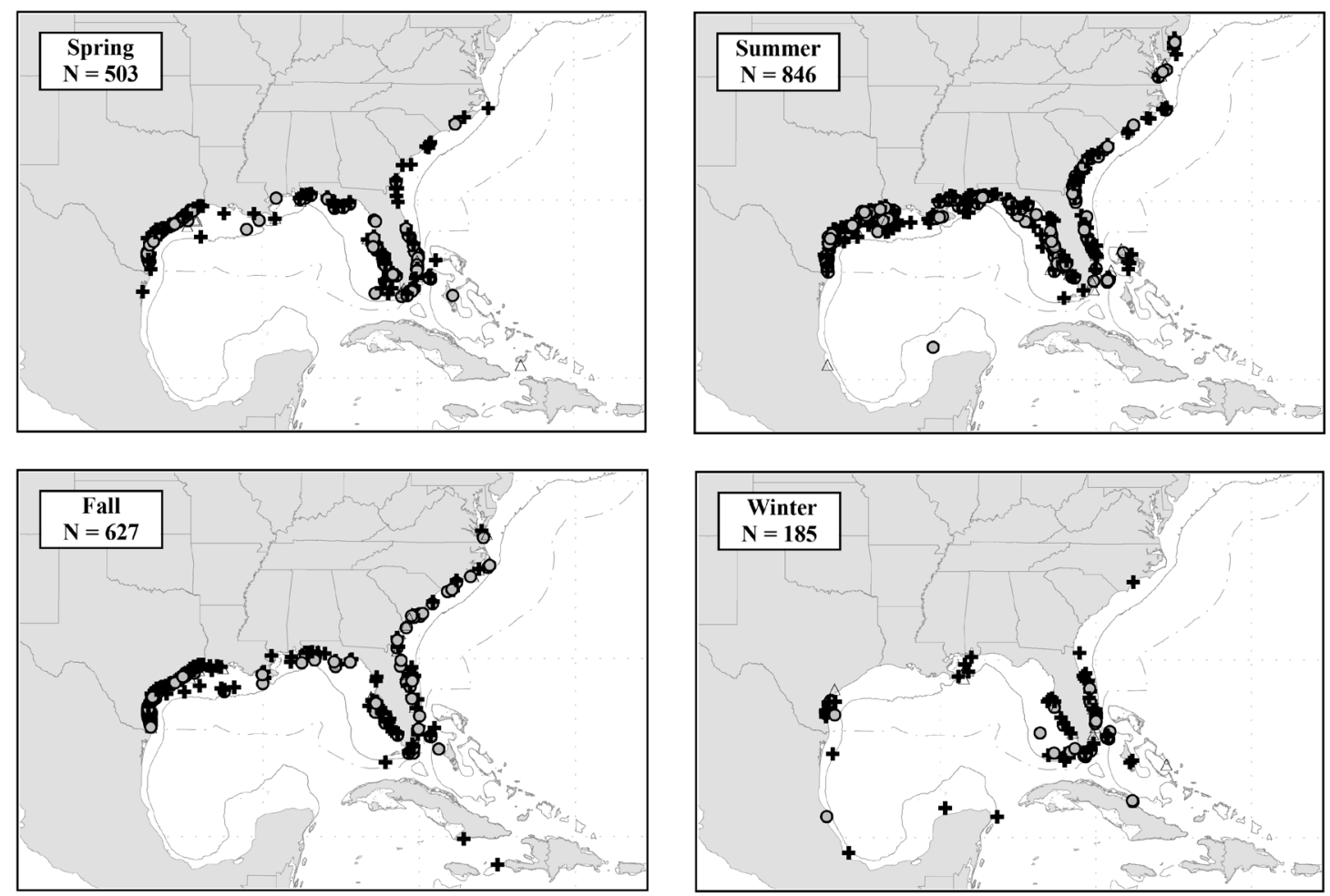

Figure 18c.- Seasonal distribution of mark/recapture locations for the bull shark, Carcharhinus leucas, from the NMFS Cooperative Shark Tagging Program (1962-2013). 


\section{Common Thresher Shark}

\begin{tabular}{|c|c|c|c|c|c|c|c|}
\hline Sex & Tags & Recaptures & $\begin{array}{c}\text { Recapture rate } \\
(\%)\end{array}$ & $\begin{array}{l}\text { Mean distance } \\
\text { traveled (nmi) }\end{array}$ & $\begin{array}{l}\text { Maximum distance } \\
\text { traveled (nmi) }\end{array}$ & $\begin{array}{l}\text { Mean time at } \\
\text { liberty (years) }\end{array}$ & $\begin{array}{l}\text { Maximum time } \\
\text { at liberty (years) }\end{array}$ \\
\hline Male & 63 & 2 & 3.2 & 71.0 & 86 & 6.1 & 8.0 \\
\hline Female & 60 & 0 & 0.0 & & & & \\
\hline Unknown & 80 & 2 & 2.5 & 168.5 & 271 & 4.7 & 6.8 \\
\hline Total & 203 & 4 & 2.0 & 119.8 & 271 & 5.4 & 8.0 \\
\hline
\end{tabular}
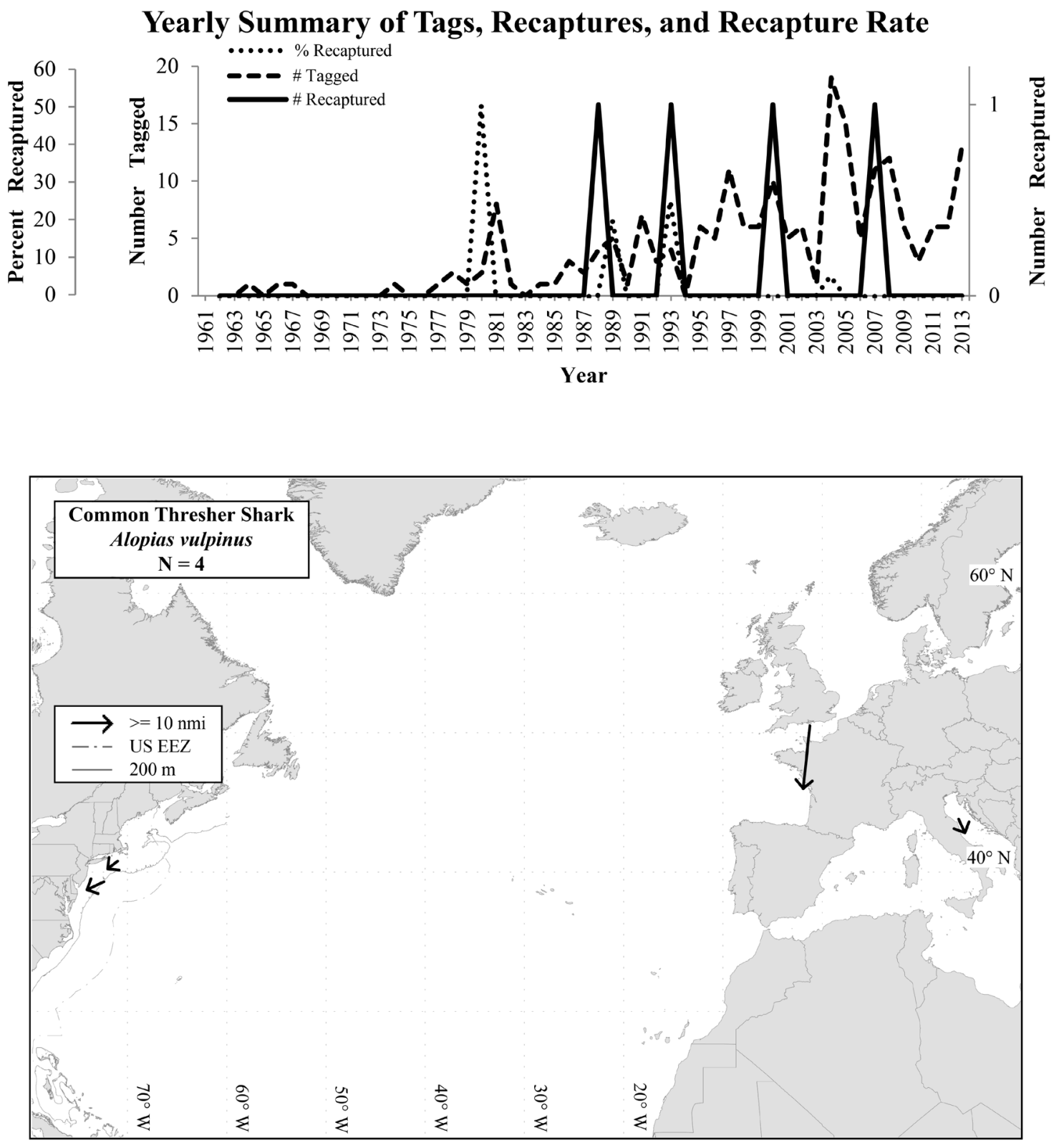

Figure 19a.-Distribution of recapture locations for the common thresher shark, Alopias vulpinus, from the NMFS Cooperative Shark Tagging Program (1962-2013). 


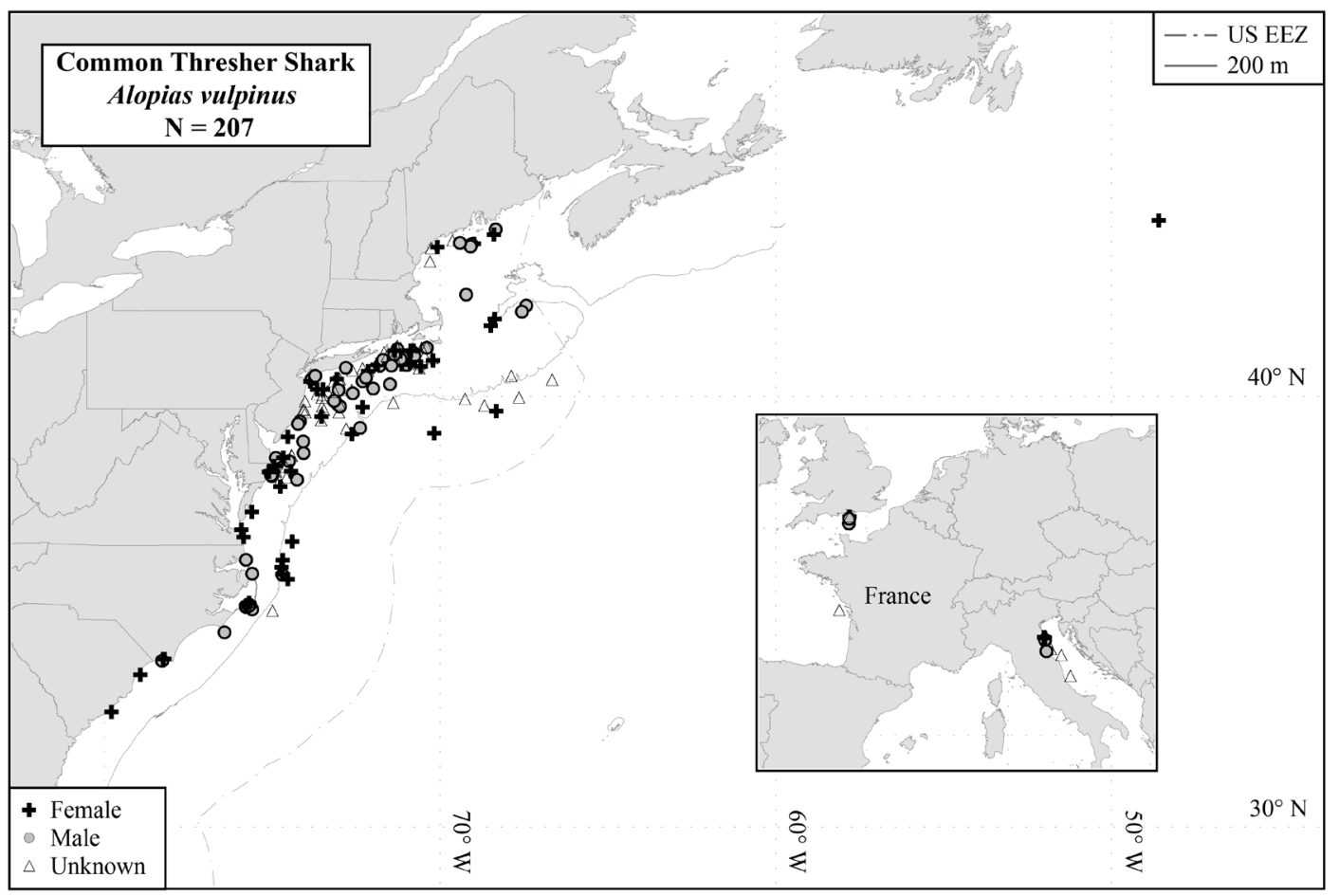

Figure 19b.-Distribution of mark/recapture locations for the common thresher shark, Alopias vulpinus, from the NMFS Cooperative Shark Tagging Program (1962-2013).
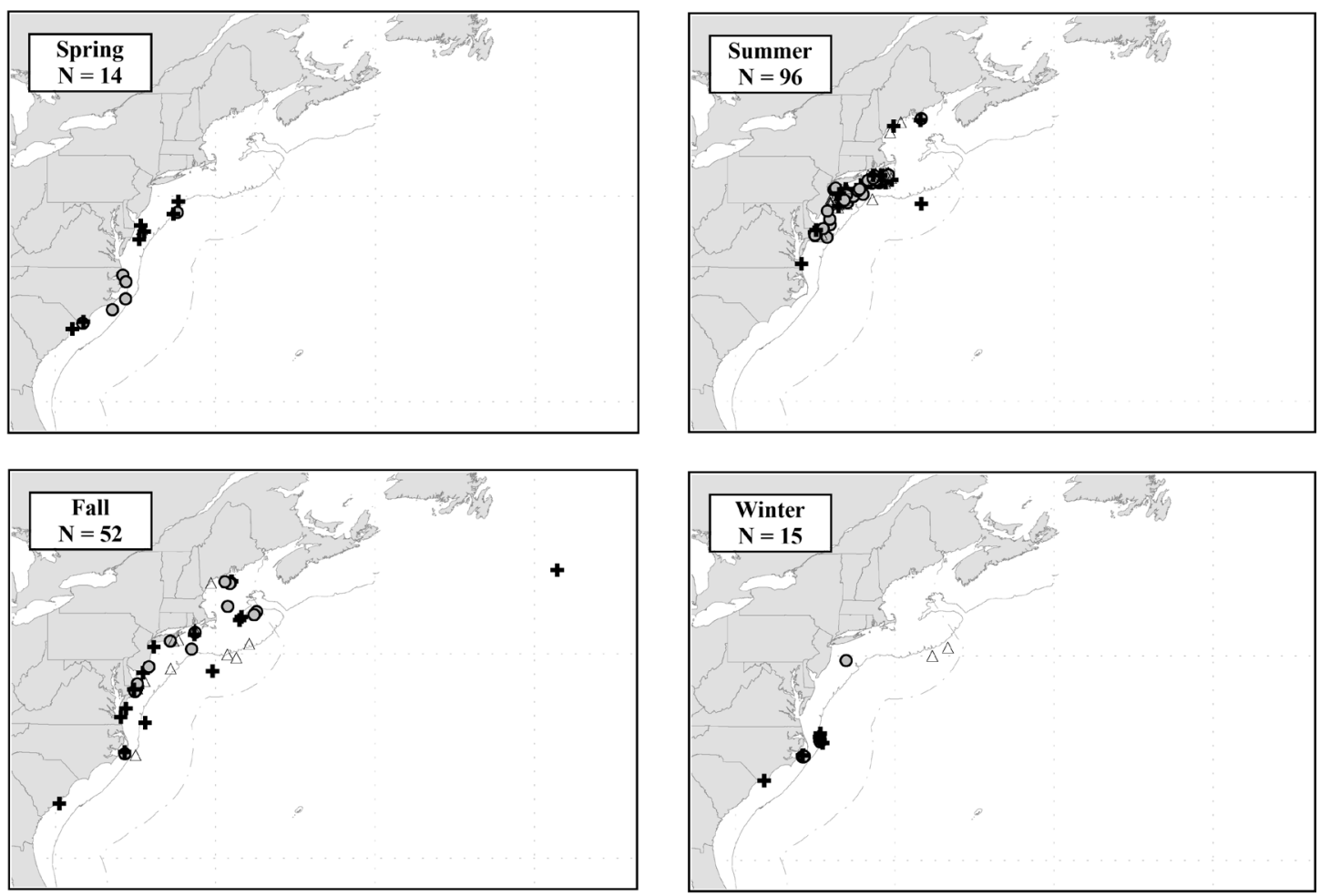

Figure 19c.- Seasonal distribution of mark/recapture locations in the western North Atlantic for the common thresher shark, Alopias vulpinus, from the NMFS Cooperative Shark Tagging Program (1962-2013). 


\section{Crocodile Shark}

\begin{tabular}{|c|c|c|c|c|c|c|c|}
\hline Sex & Tags & Recaptures & $\begin{array}{c}\text { Recapture rate } \\
(\%)\end{array}$ & $\begin{array}{l}\text { Mean distance } \\
\text { traveled (nmi) }\end{array}$ & $\begin{array}{l}\text { Maximum distance } \\
\text { traveled (nmi) }\end{array}$ & $\begin{array}{l}\text { Mean time at } \\
\text { liberty (years) }\end{array}$ & $\begin{array}{l}\text { Maximum time } \\
\text { at liberty (years) }\end{array}$ \\
\hline Male & 9 & 0 & 0.0 & & & & \\
\hline Female & 10 & 0 & 0.0 & & & & \\
\hline Unknown & 1 & 0 & 0.0 & & & & \\
\hline Total & 20 & 0 & 0.0 & & & & \\
\hline
\end{tabular}

\section{Yearly Summary of Tags}
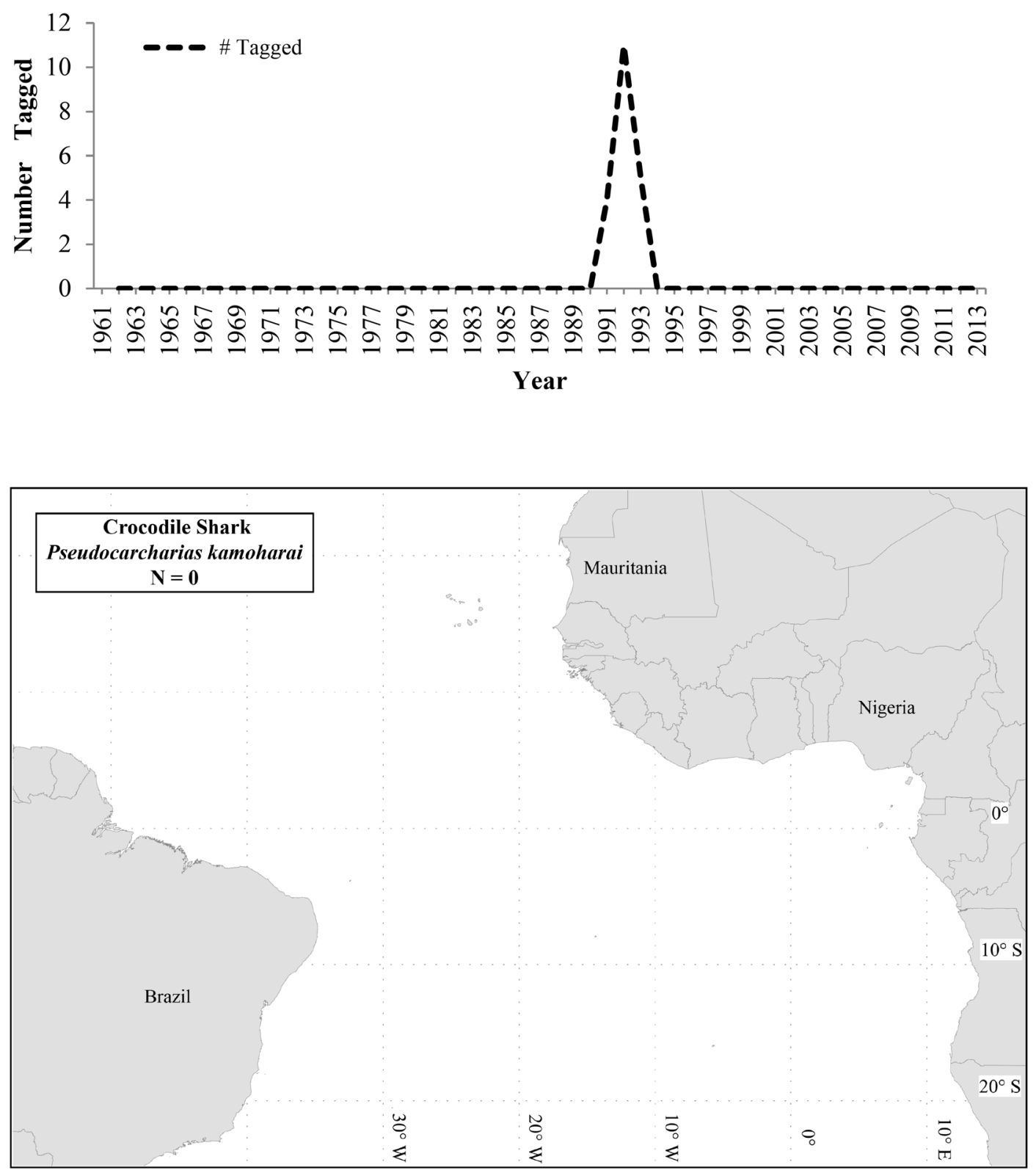

Figure 20a.-Distribution of recapture locations for the crocodile shark, Pseudocarcharias kamoharai, from the NMFS Cooperative Shark Tagging Program (1962-2013). 


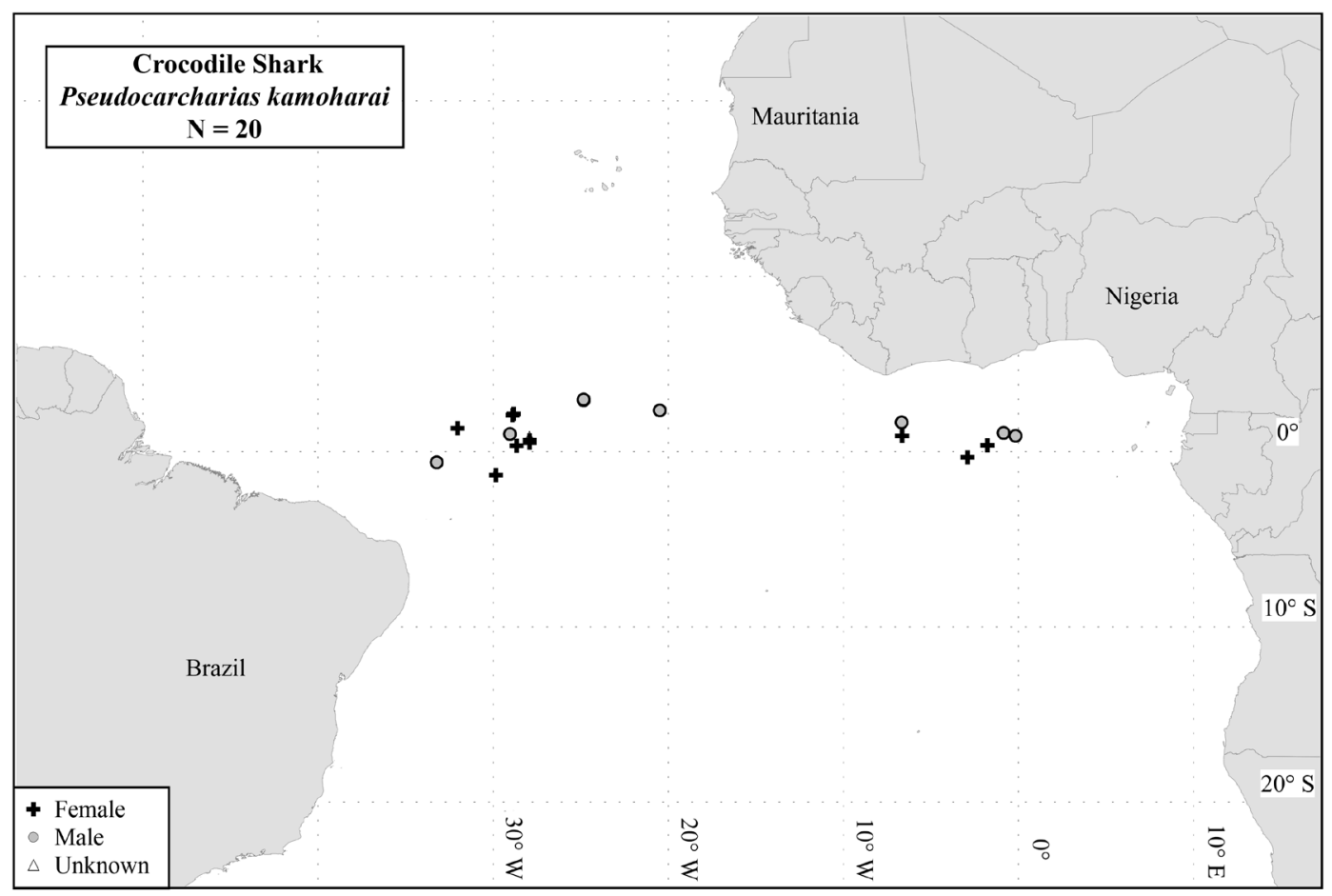

Figure 20b.-Distribution of mark/recapture locations for the crocodile shark, Pseudocarcharias kamoharai, from the NMFS Cooperative Shark Tagging Program (1962-2013).
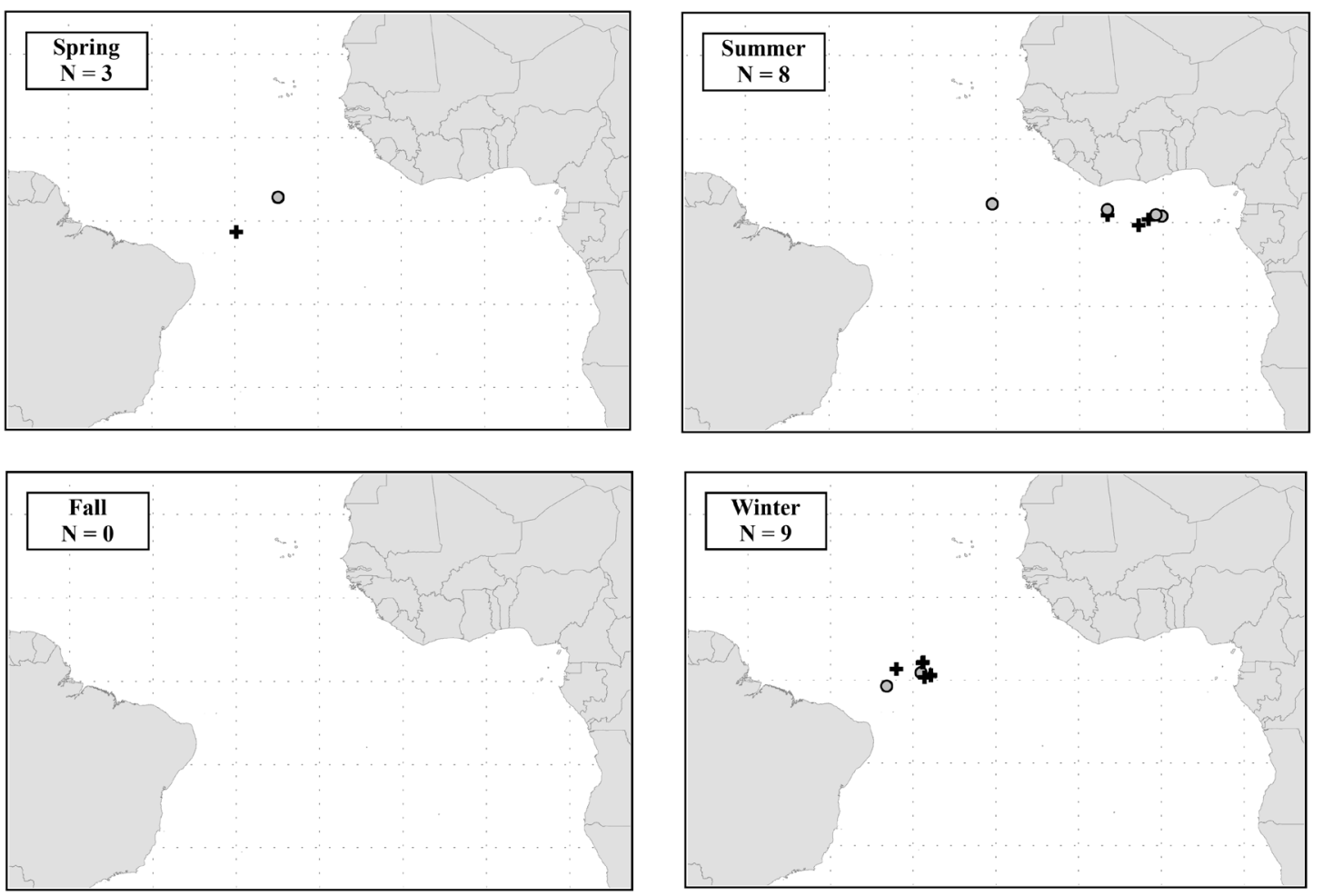

Figure 20c.- Seasonal distribution of mark/recapture locations for the crocodile shark, Pseudocarcharias kamoharai, from the NMFS Cooperative Shark Tagging Program (1962-2013). 


\section{Dusky Shark}

\begin{tabular}{|c|c|c|c|c|c|c|c|}
\hline Sex & Tags & Recaptures & $\begin{array}{c}\text { Recapture rate } \\
(\%)\end{array}$ & $\begin{array}{l}\text { Mean distance } \\
\text { traveled (nmi) }\end{array}$ & $\begin{array}{l}\text { Maximum distance } \\
\text { traveled (nmi) }\end{array}$ & $\begin{array}{l}\text { Mean time at } \\
\text { liberty (years) }\end{array}$ & $\begin{array}{l}\text { Maximum time } \\
\text { at liberty (years) }\end{array}$ \\
\hline Male & 2,146 & 49 & 2.3 & 607.7 & 2,015 & 2.8 & 11.8 \\
\hline Female & 3,723 & 72 & 1.9 & 583.5 & 2,017 & 3.6 & 16.1 \\
\hline Unknown & 2,596 & 43 & 1.7 & 548.4 & 2,052 & 3.0 & 15.8 \\
\hline Total & 8,465 & 164 & 1.9 & 581.9 & 2,052 & 3.2 & 16.1 \\
\hline
\end{tabular}

\section{Yearly Summary of Tags, Recaptures, and Recapture Rate}

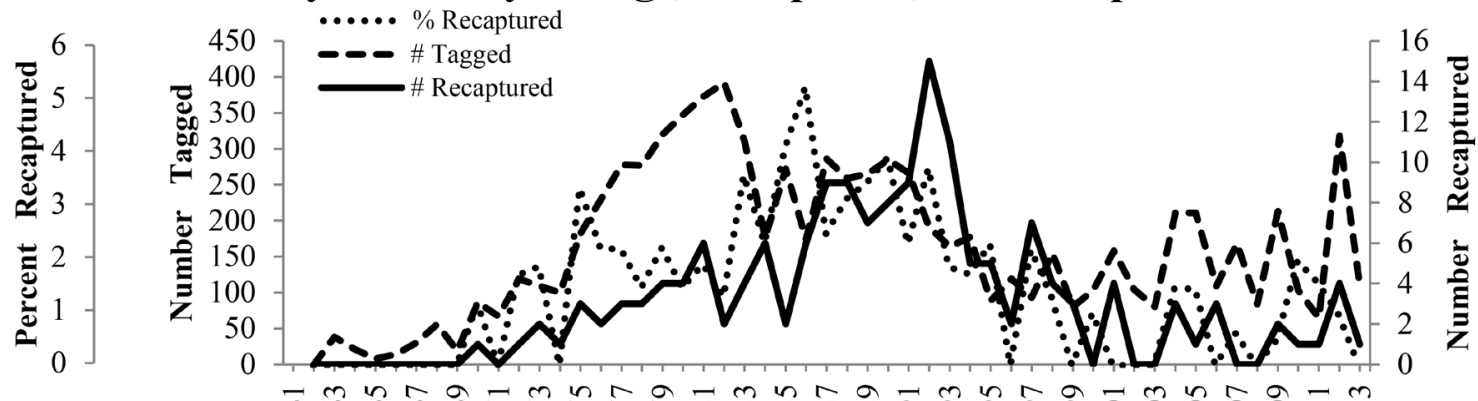

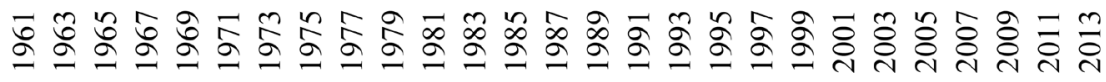

Year

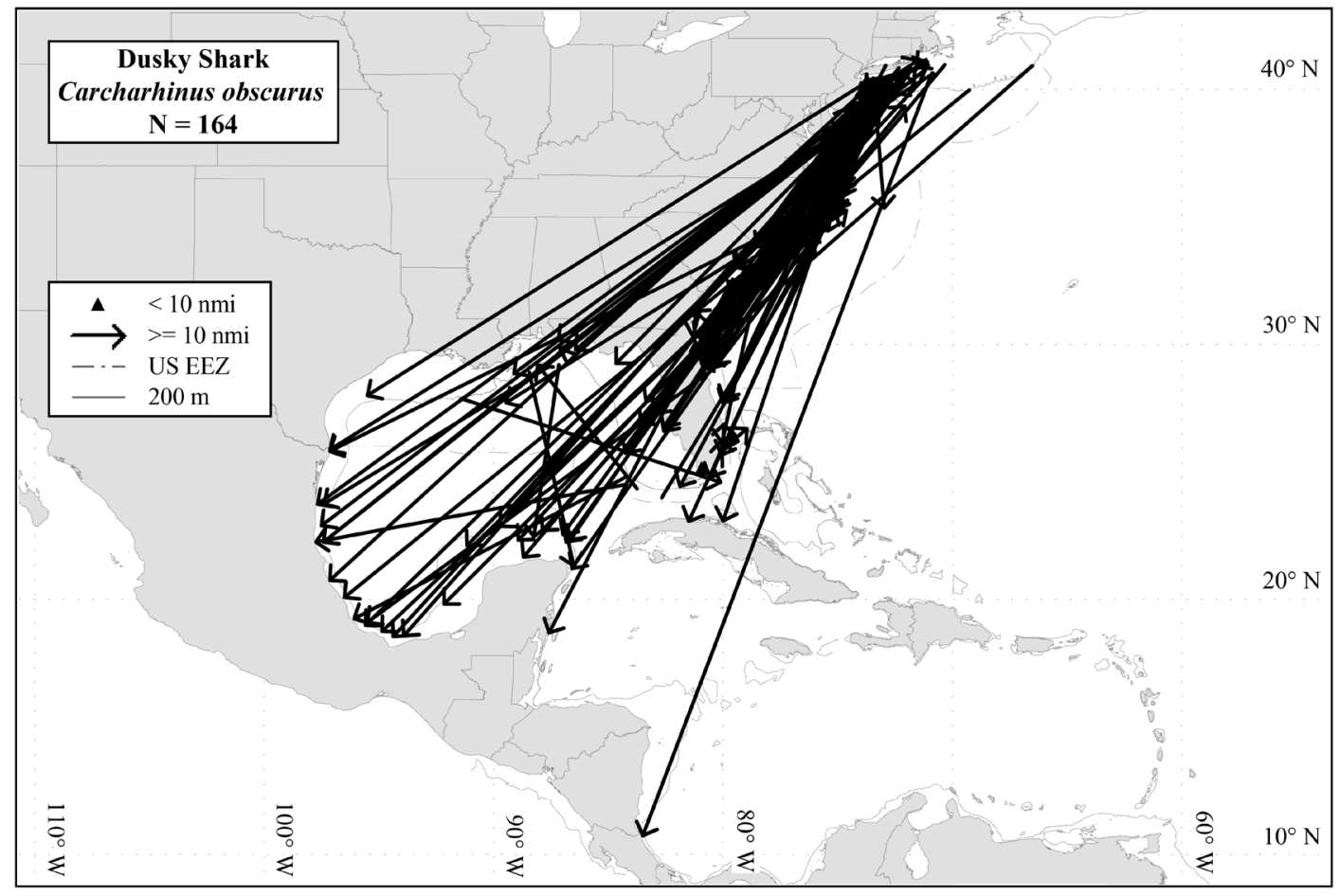

Figure 21a.-Distribution of recapture locations for the dusky shark, Carcharhinus obscurus, from the NMFS Cooperative Shark Tagging Program (1962-2013). 


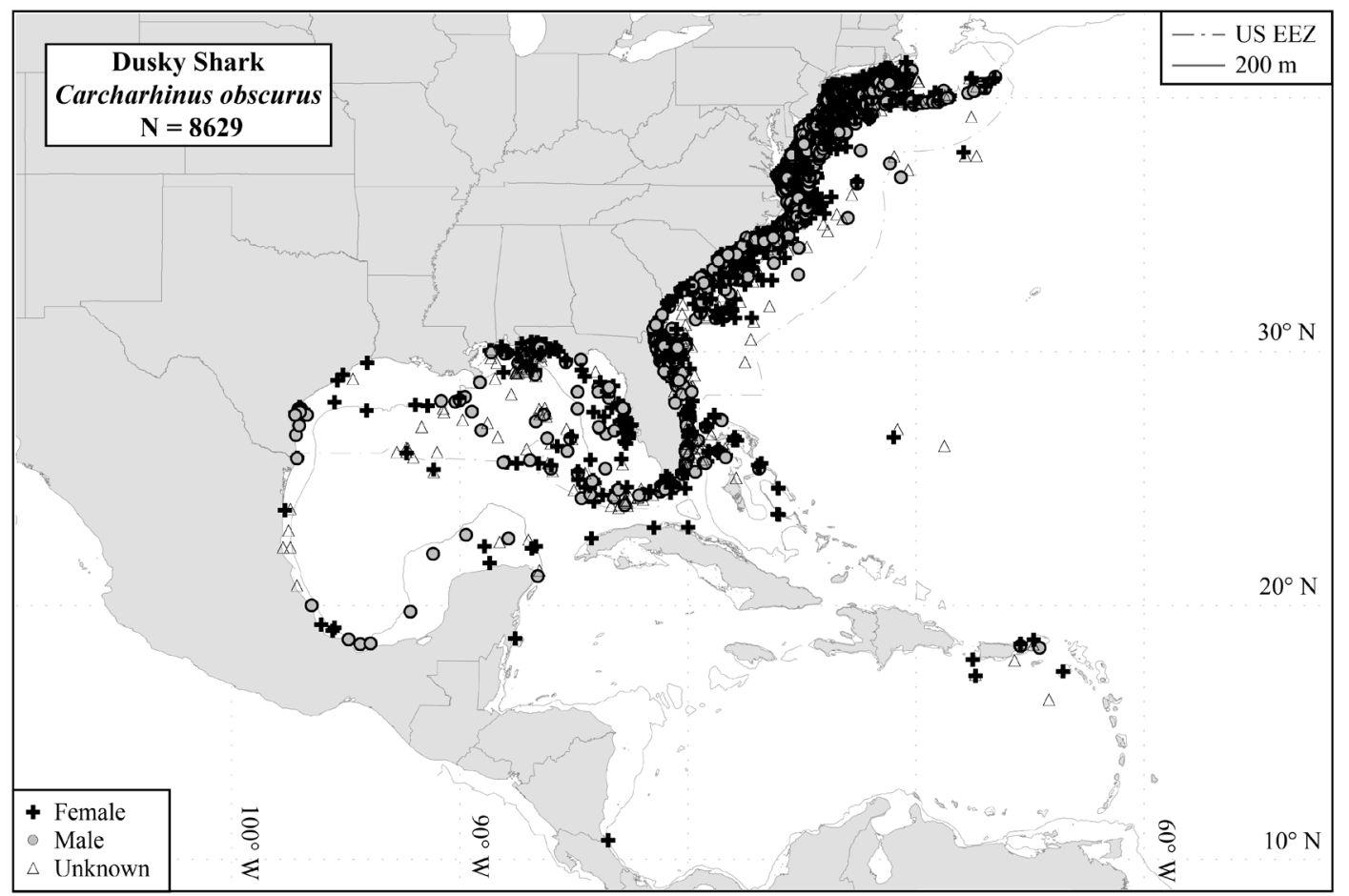

Figure 21b.-Distribution of mark/recapture locations for the dusky shark, Carcharhinus obscurus, from the NMFS Cooperative Shark Tagging Program (1962-2013).
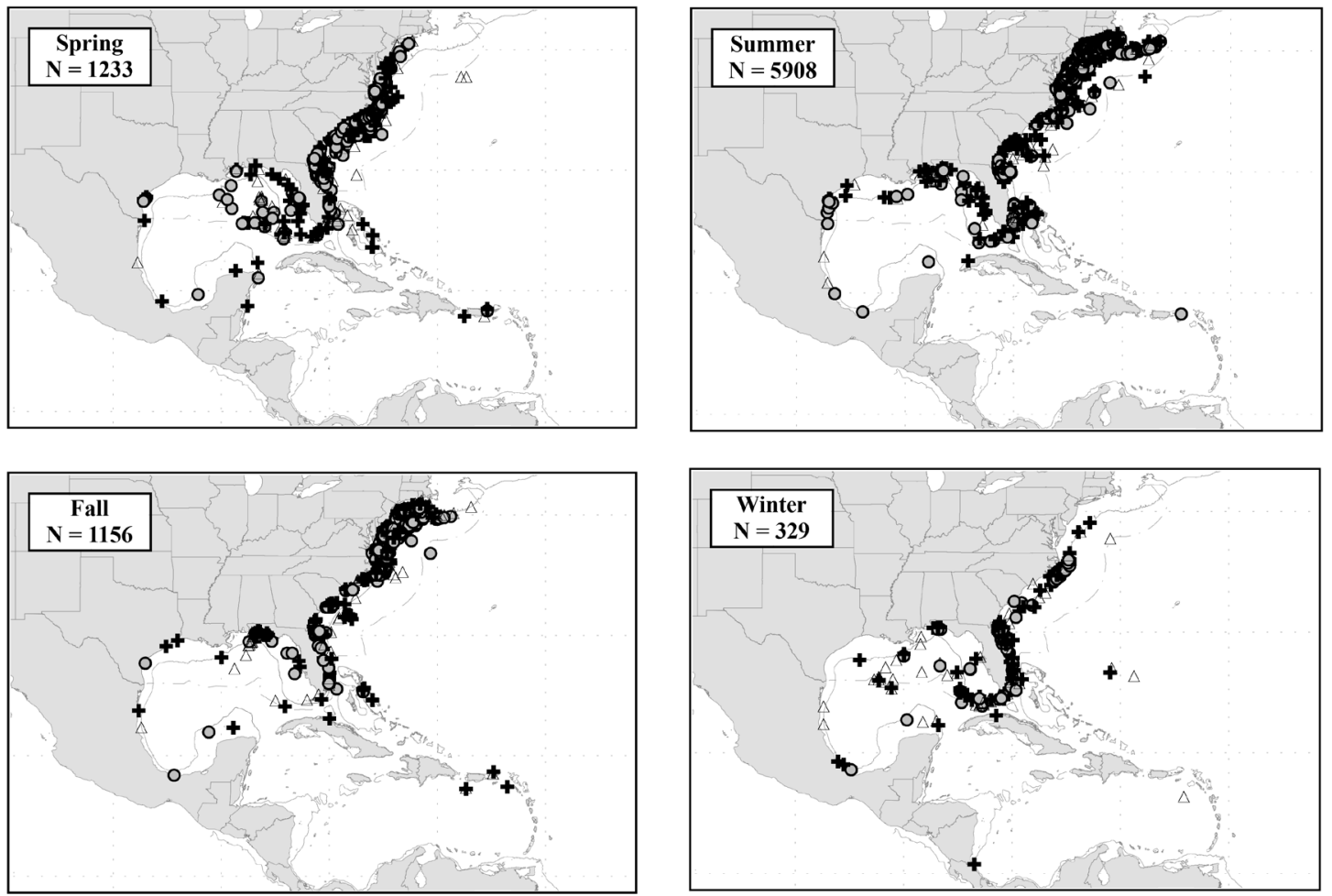

Figure 21c.- Seasonal distribution of mark/recapture locations for the dusky shark, Carcharhinus obscurus, from the NMFS Cooperative Shark Tagging Program (1962-2013). 


\section{Finetooth Shark}

\begin{tabular}{|c|c|c|c|c|c|c|c|}
\hline Sex & Tags & Recaptures & $\begin{array}{c}\text { Recapture rate } \\
(\%)\end{array}$ & $\begin{array}{l}\text { Mean distance } \\
\text { traveled (nmi) }\end{array}$ & $\begin{array}{l}\text { Maximum distance } \\
\text { traveled (nmi) }\end{array}$ & $\begin{array}{l}\text { Mean time at } \\
\text { liberty (years) }\end{array}$ & $\begin{array}{l}\text { Maximum time } \\
\text { at liberty (years) }\end{array}$ \\
\hline Male & 1,289 & 25 & 1.9 & 55.2 & 351 & 0.5 & 3.9 \\
\hline Female & 1,475 & 35 & 2.4 & 43.5 & 365 & 0.6 & 4.9 \\
\hline Unknown & 43 & 0 & 0.0 & & & & \\
\hline Total & 2,807 & 60 & 2.1 & 48.4 & 365 & 0.5 & 4.9 \\
\hline
\end{tabular}

\section{Yearly Summary of Tags, Recaptures, and Recapture Rate}

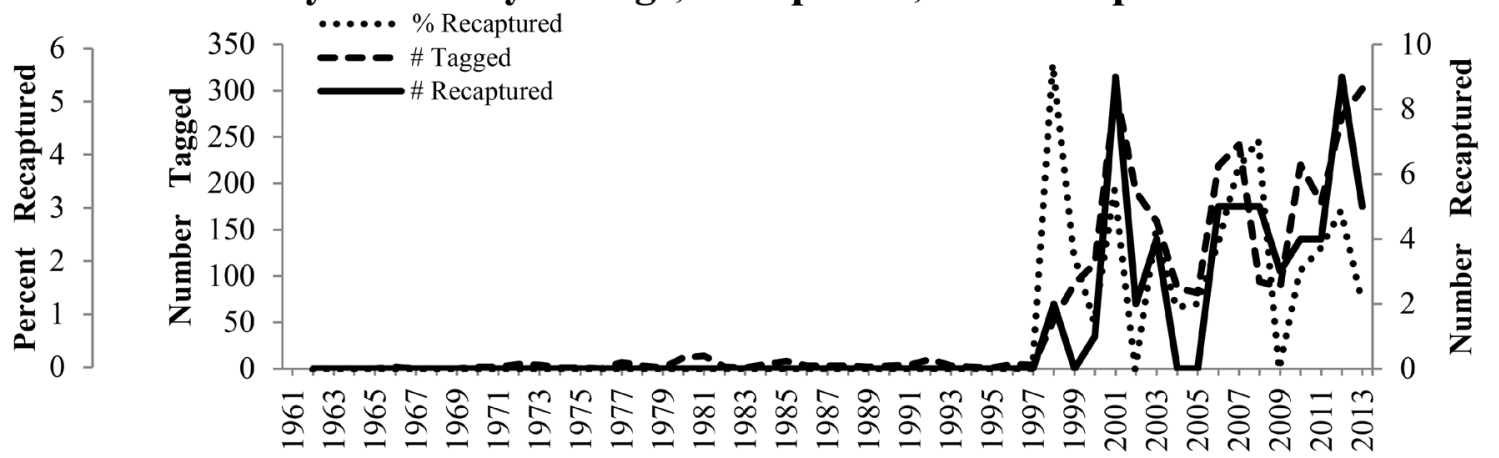

Year

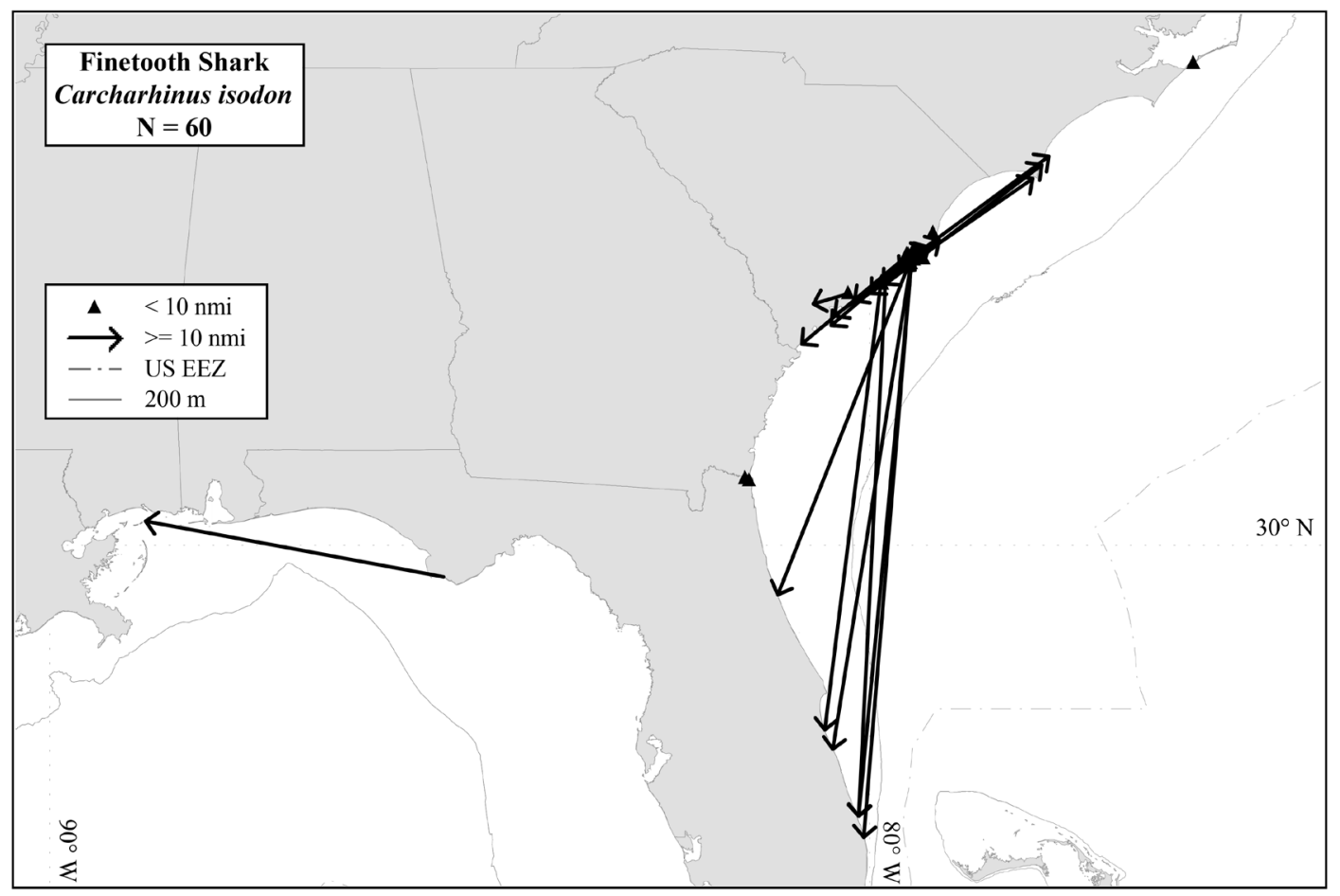

Figure 22a.-Distribution of recapture locations for the finetooth shark, Carcharhinus isodon, from the NMFS Cooperative Shark Tagging Program (1962-2013). 


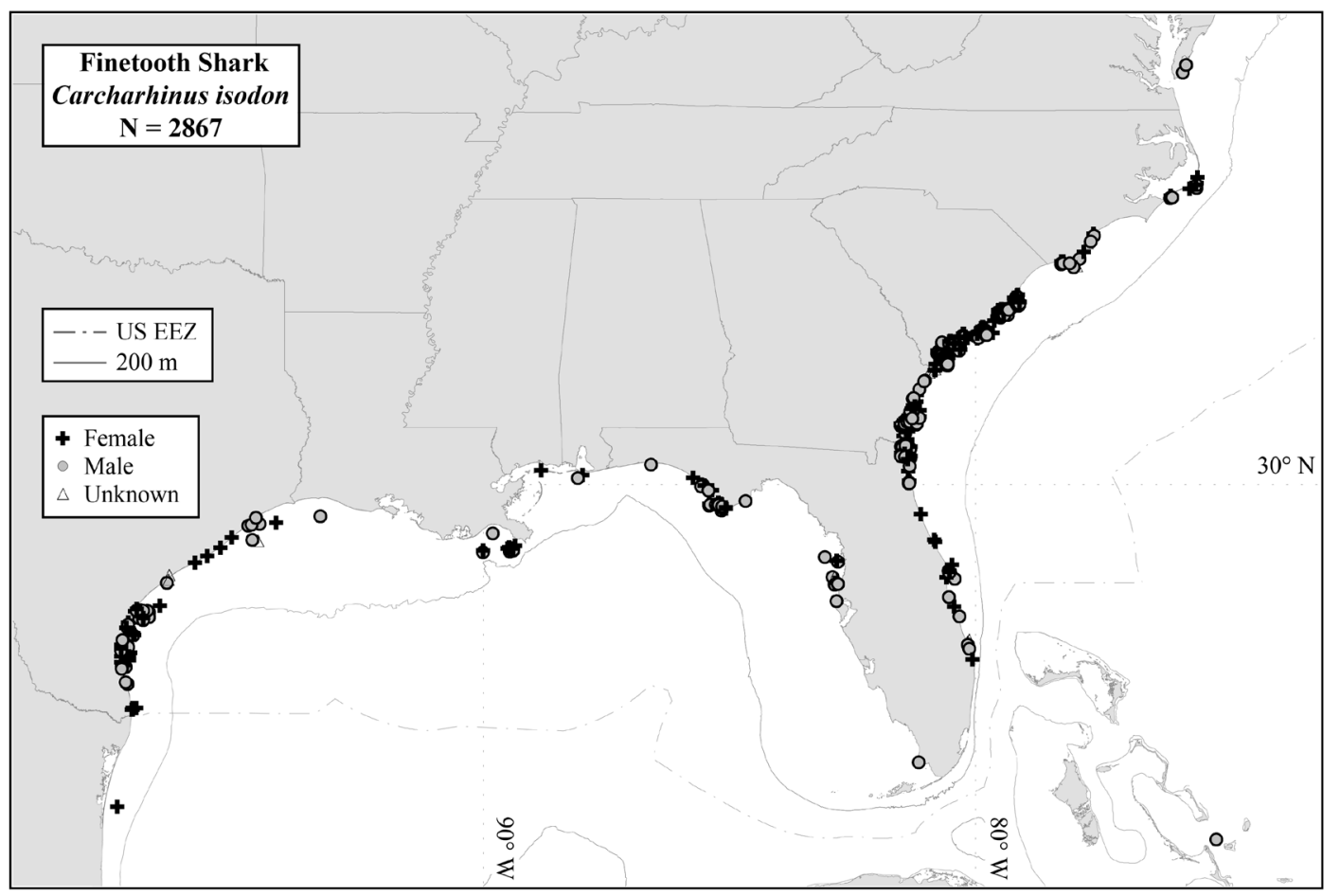

Figure 22b.-Distribution of mark/recapture locations for the finetooth shark, Carcharhinus isodon, from the NMFS Cooperative Shark Tagging Program (1962-2013).
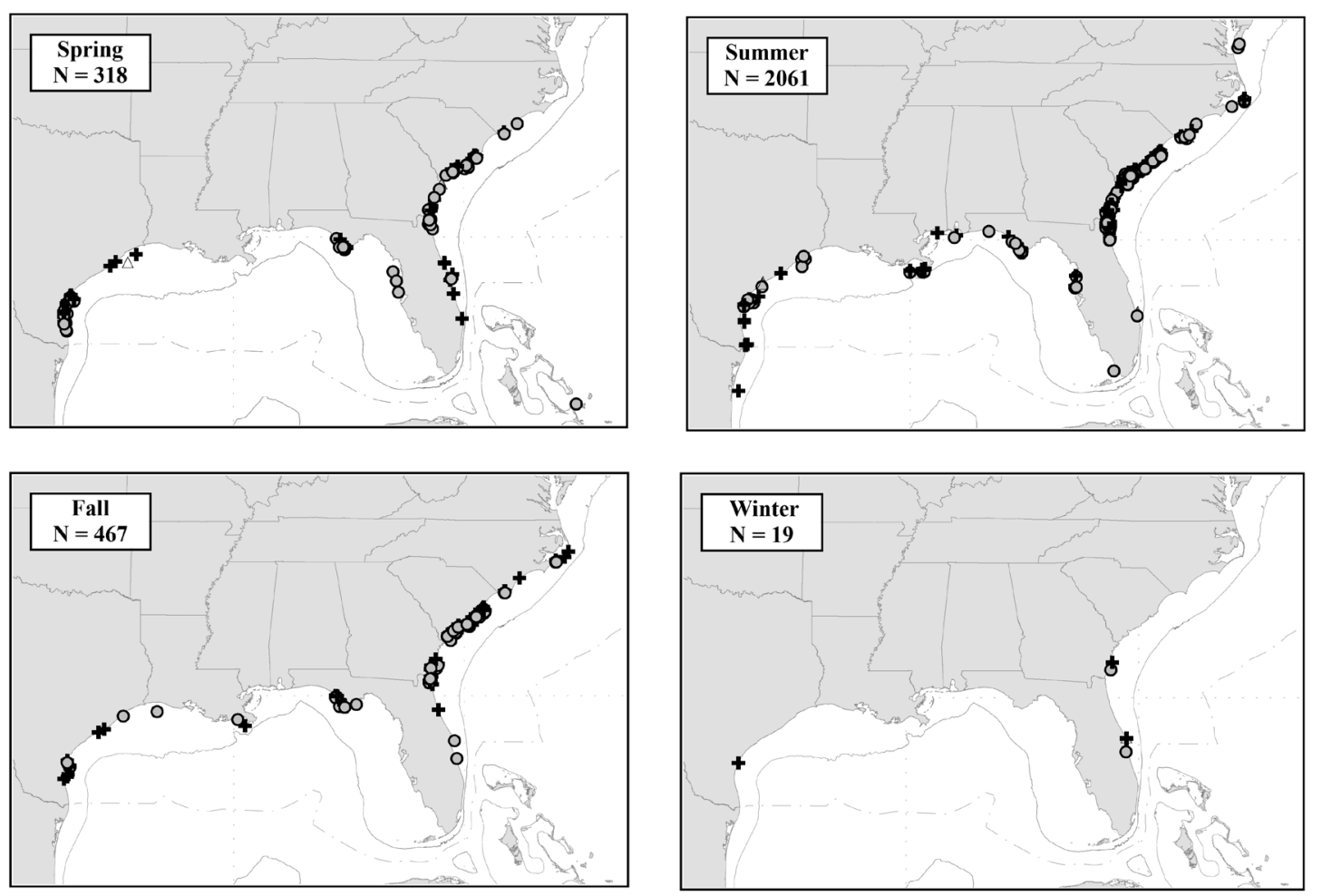

Figure 22c.-Seasonal distribution of mark/recapture locations for the finetooth shark, Carcharhinus isodon, from the NMFS Cooperative Shark Tagging Program (1962-2013). 


\section{Galapagos Shark}

\begin{tabular}{|c|c|c|c|c|c|c|c|}
\hline Sex & Tags & Recaptures & $\begin{array}{c}\text { Recapture rate } \\
(\%)\end{array}$ & $\begin{array}{l}\text { Mean distance } \\
\text { traveled (nmi) }\end{array}$ & $\begin{array}{l}\text { Maximum distance } \\
\text { traveled (nmi) }\end{array}$ & $\begin{array}{l}\text { Mean time at } \\
\text { liberty (years) }\end{array}$ & $\begin{array}{l}\text { Maximum time } \\
\text { at liberty (years) }\end{array}$ \\
\hline Male & 178 & 7 & 3.9 & 256.3 & 1,087 & 3.0 & 7.1 \\
\hline Female & 195 & 9 & 4.6 & 71.9 & 505 & 1.7 & 3.8 \\
\hline Unknown & 49 & 2 & 4.1 & 16.0 & 32 & 3.0 & 4.2 \\
\hline Total & 422 & 18 & 4.3 & 137.4 & 1,087 & 2.3 & 7.1 \\
\hline
\end{tabular}

\section{Yearly Summary of Tags, Recaptures, and Recapture Rate}

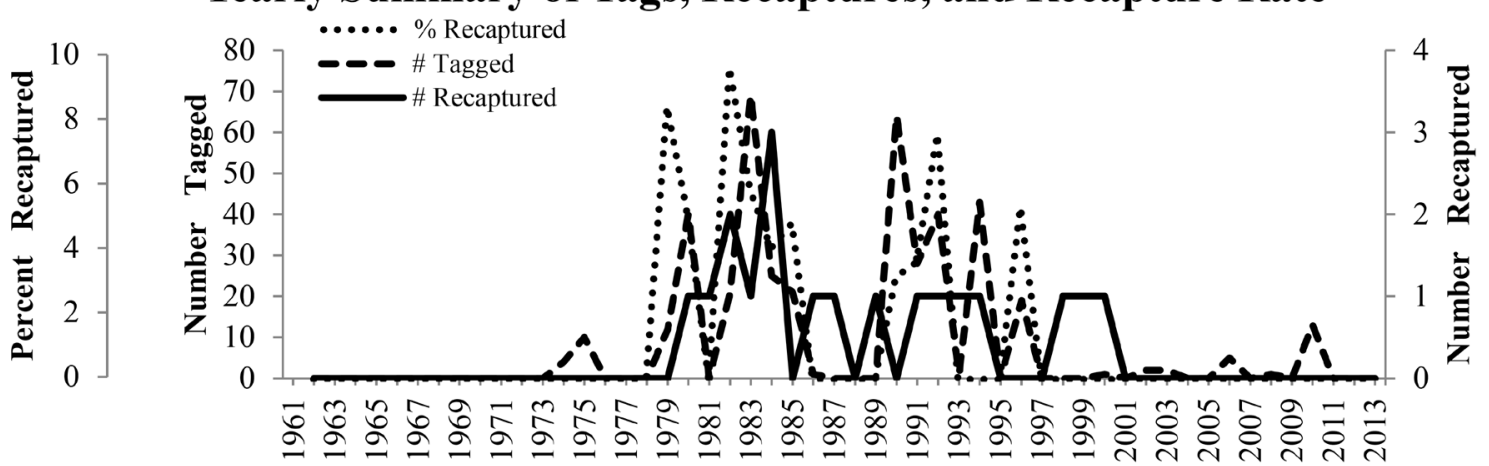

Year

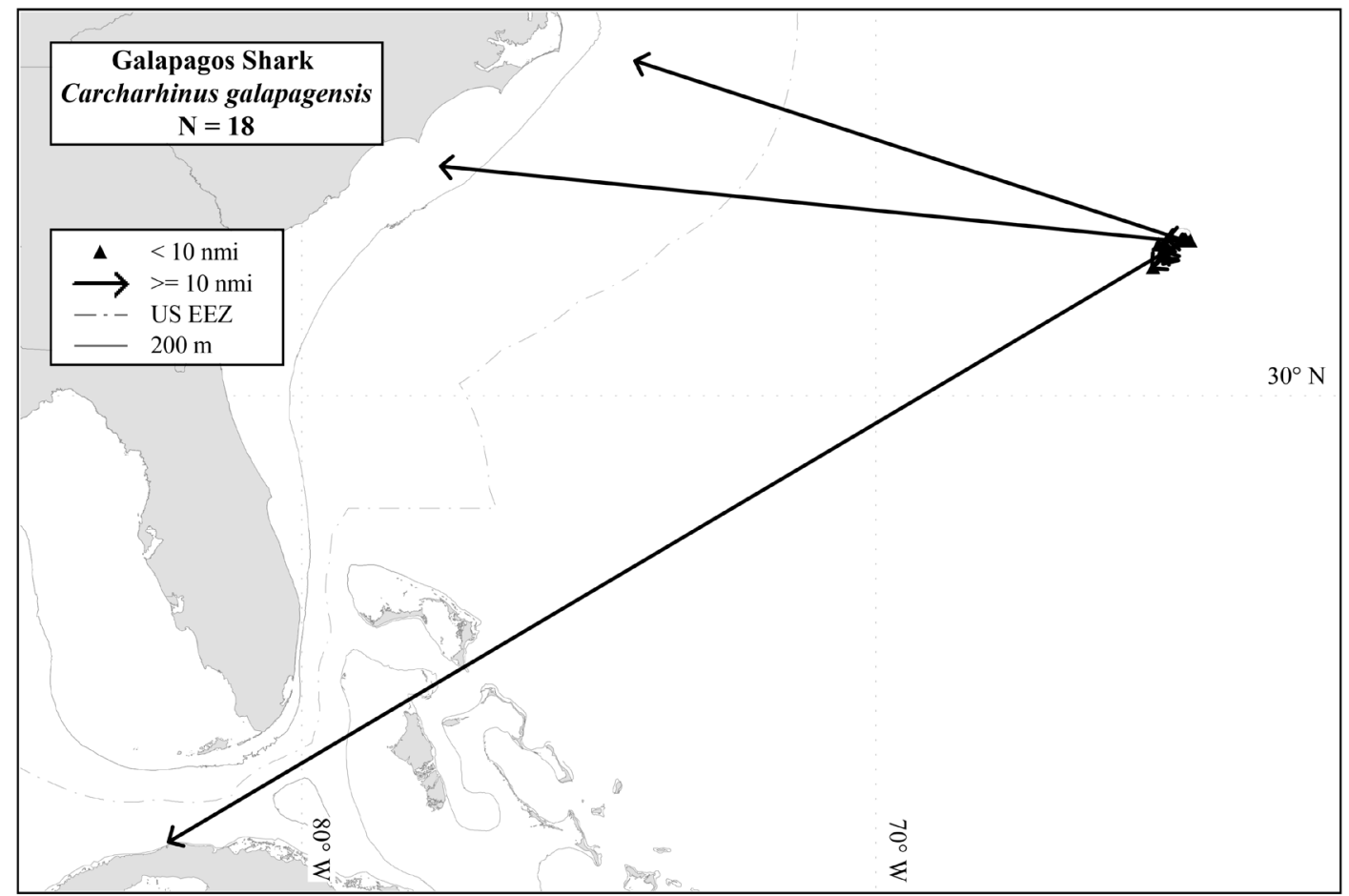

Figure 23a.-Distribution of recapture locations for the Galapagos shark, Carcharhinus galapagensis, from the NMFS Cooperative Shark Tagging Program (1962-2013). 


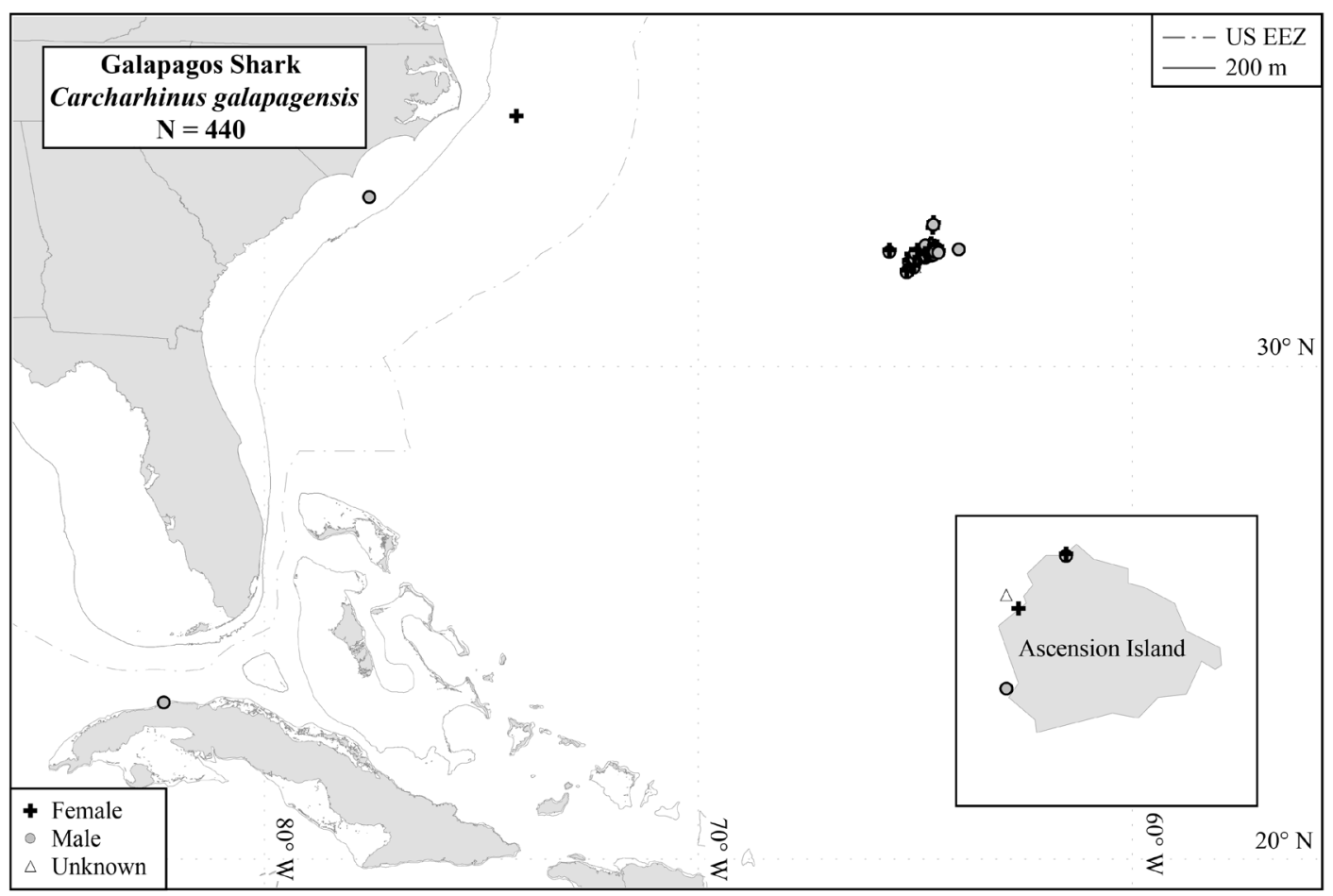

Figure 23b.-Distribution of mark/recapture locations for the Galapagos shark, Carcharhinus galapagensis, from the NMFS Cooperative Shark Tagging Program (1962-2013).
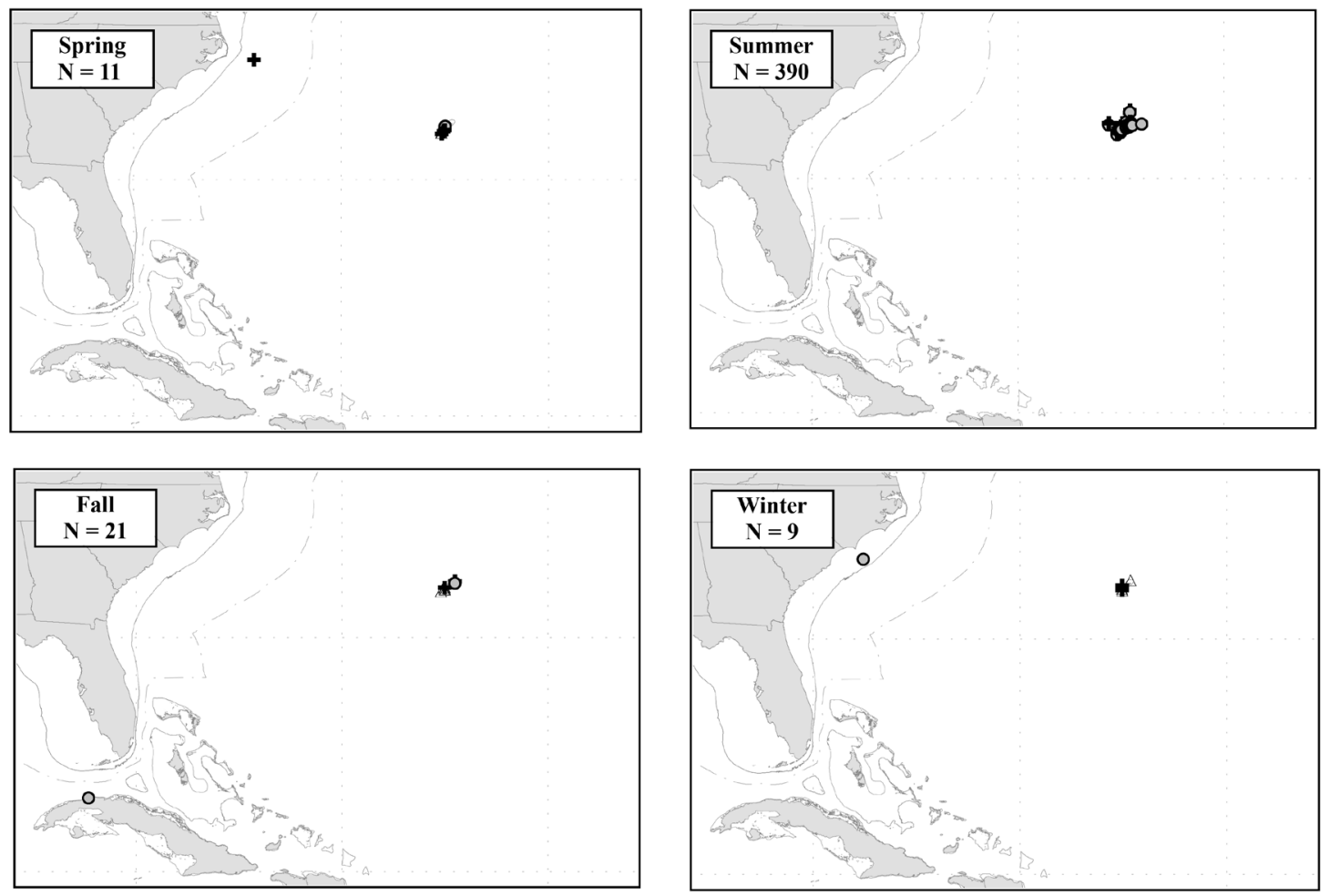

Figure 23c.- Seasonal distribution of mark/recapture locations in the western North Atlantic for the Galapagos shark, Carcharhinus galapagensis, from the NMFS Cooperative Shark Tagging Program (1962-2013). 


\section{Great Hammerhead}

\begin{tabular}{|c|c|c|c|c|c|c|c|}
\hline Sex & Tags & Recaptures & $\begin{array}{c}\text { Recapture rate } \\
(\%)\end{array}$ & $\begin{array}{l}\text { Mean distance } \\
\text { traveled (nmi) }\end{array}$ & $\begin{array}{l}\text { Maximum distance } \\
\text { traveled (nmi) }\end{array}$ & $\begin{array}{l}\text { Mean time at } \\
\text { liberty (years) }\end{array}$ & $\begin{array}{l}\text { Maximum time } \\
\text { at liberty (years) }\end{array}$ \\
\hline Male & 102 & 1 & 1.0 & 2.0 & 2 & 0.2 & 0.2 \\
\hline Female & 126 & 2 & 1.6 & 52.0 & 102 & 1.0 & 1.2 \\
\hline Unknown & 54 & 2 & 3.7 & 575.5 & 649 & 3.1 & 3.4 \\
\hline Total & 282 & 5 & 1.8 & 251.4 & 649 & 1.7 & 3.4 \\
\hline
\end{tabular}

Yearly Summary of Tags, Recaptures, and Recapture Rate

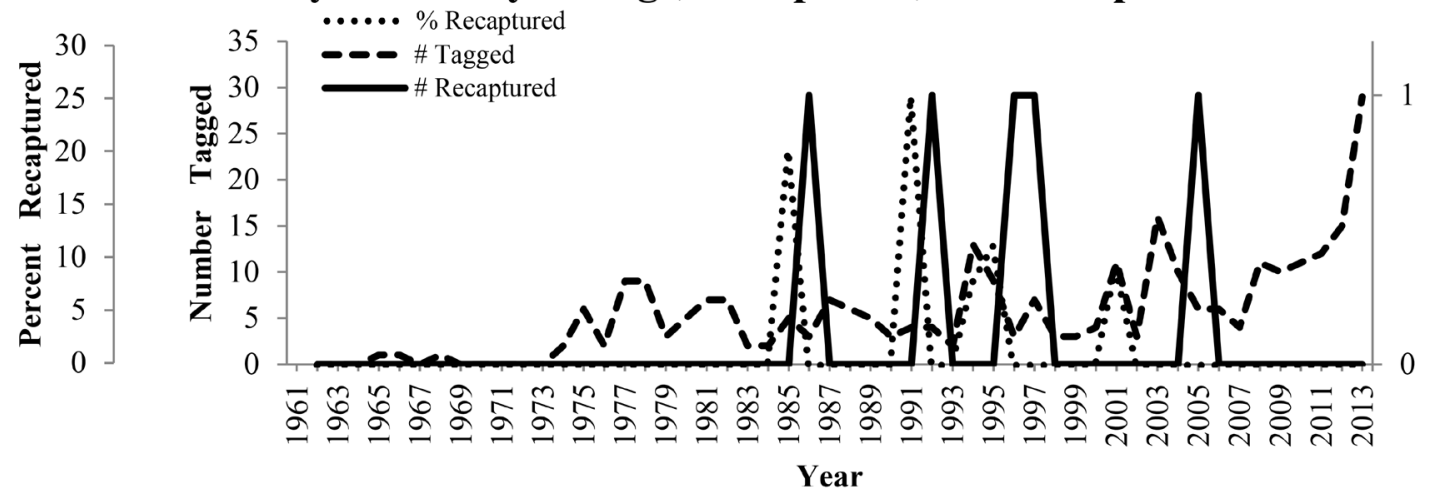

:

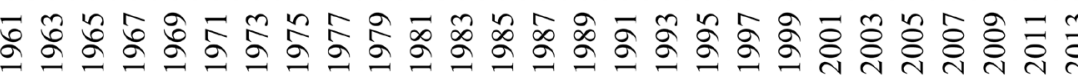

Year

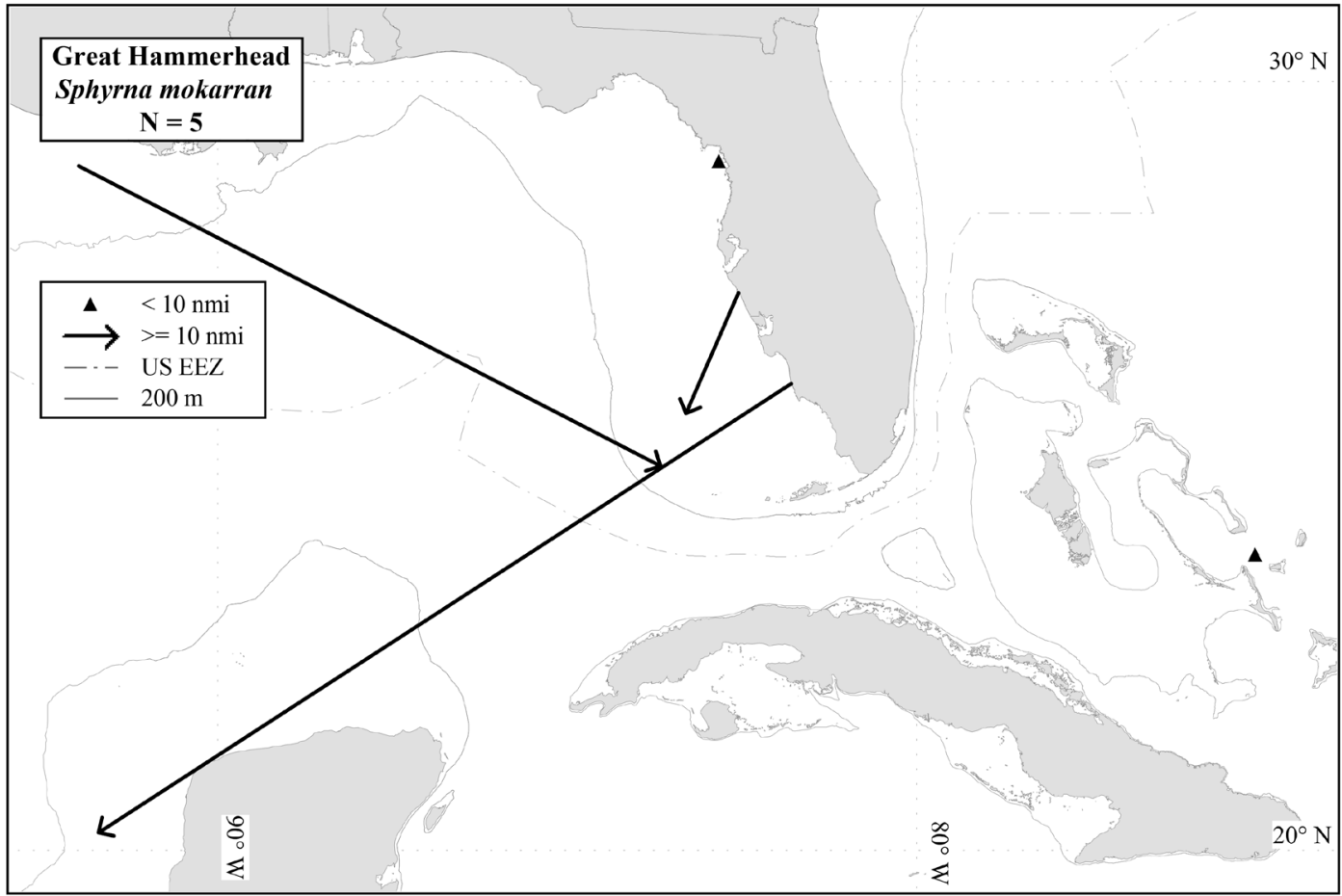

Figure 24a.-Distribution of recapture locations for the great hammerhead, Sphyrna mokarran, from the NMFS Cooperative Shark Tagging Program (1962-2013). 


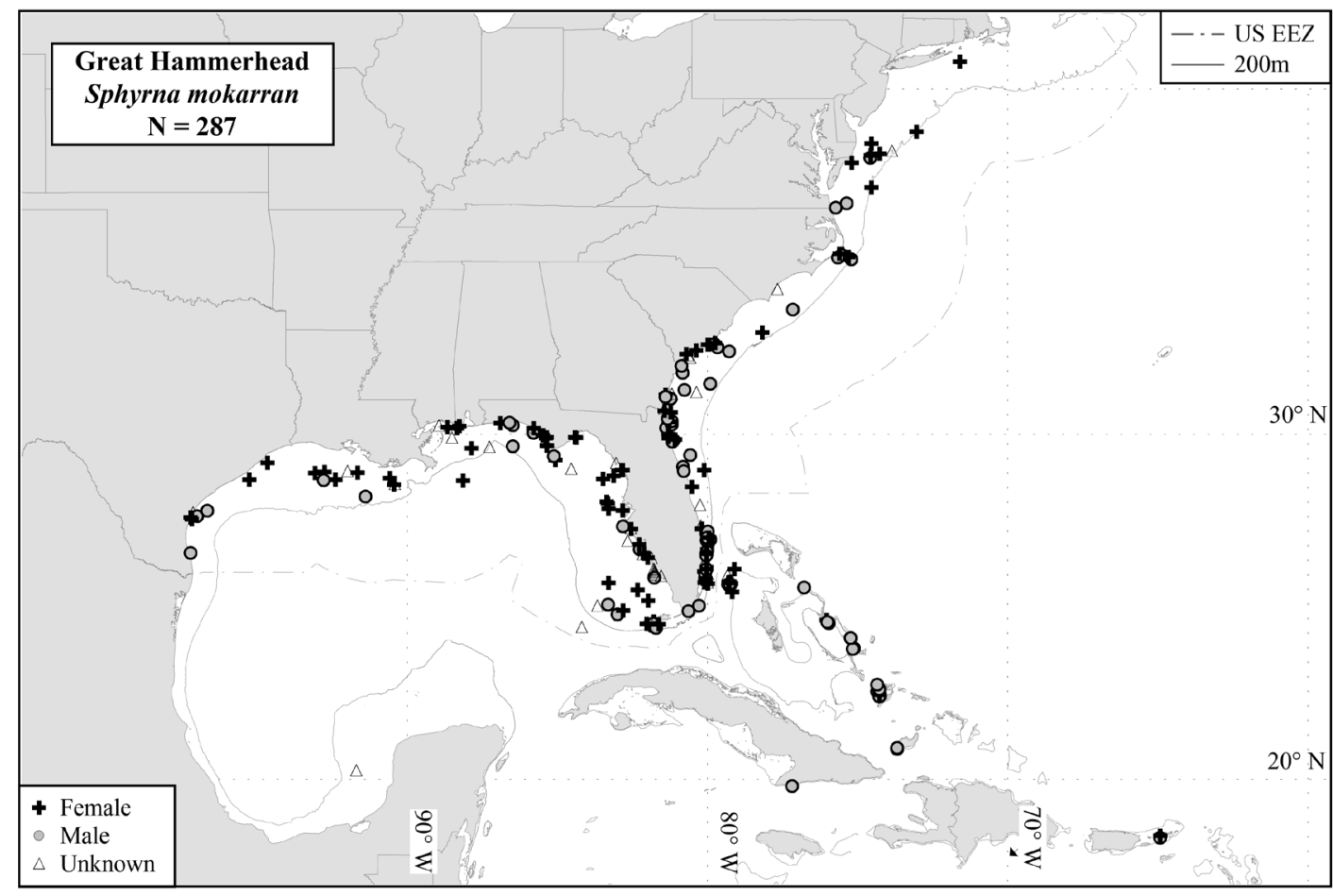

Figure 24b.-Distribution of mark/recapture locations for the great hammerhead, Sphyrna mokarran, from the NMFS Cooperative Shark Tagging Program (1962-2013).
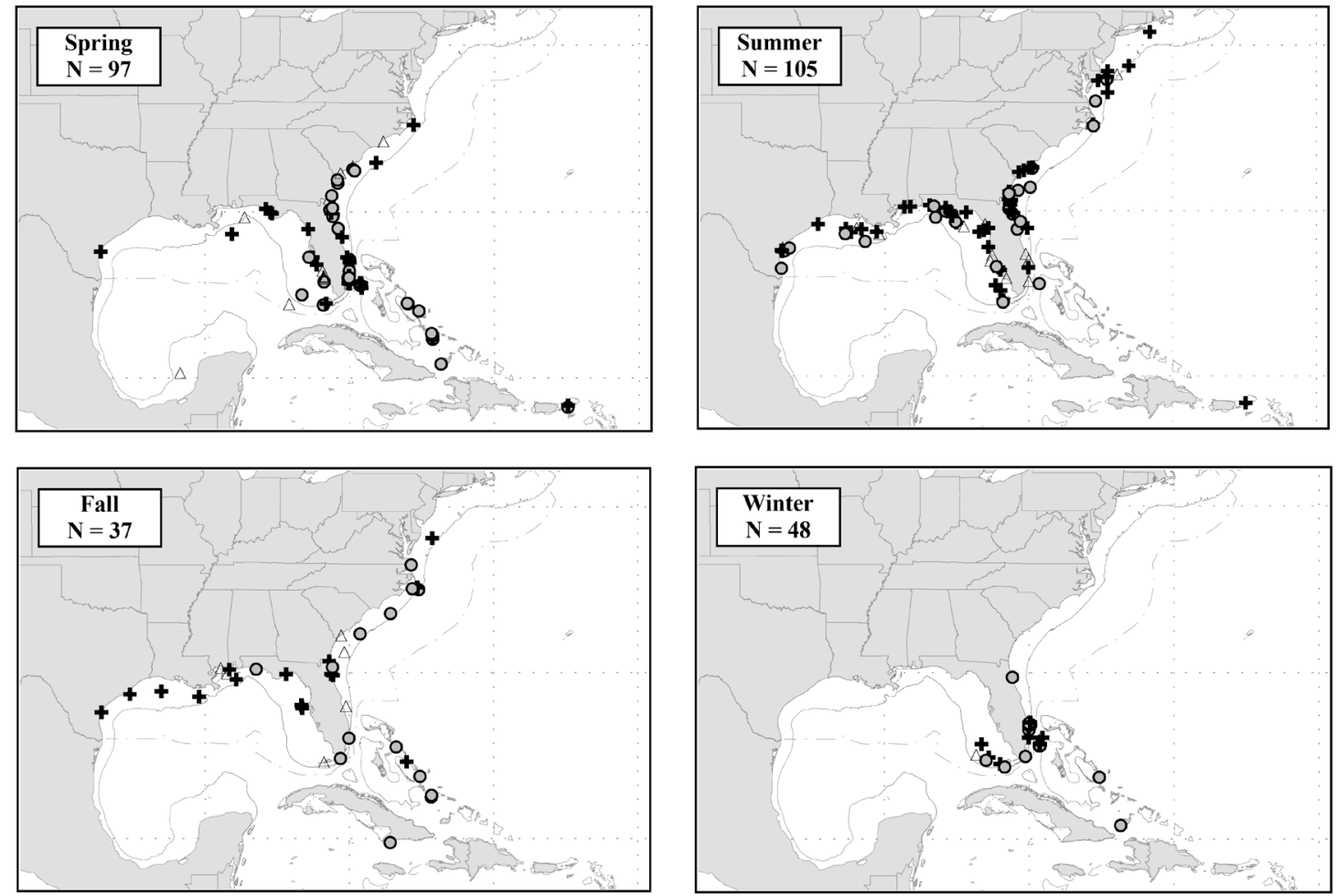

Figure 24c.- - Seasonal distribution of mark/recapture locations for the great hammerhead, Sphyrna mokarran, from the NMFS Cooperative Shark Tagging Program (1962-2013). 


\section{Greenland Shark}

\begin{tabular}{|c|c|c|c|c|c|c|c|}
\hline Sex & Tags & Recaptures & $\begin{array}{c}\text { Recapture rate } \\
(\%)\end{array}$ & $\begin{array}{l}\text { Mean distance } \\
\text { traveled (nmi) }\end{array}$ & $\begin{array}{l}\text { Maximum distance } \\
\text { traveled (nmi) }\end{array}$ & $\begin{array}{l}\text { Mean time at } \\
\text { liberty (years) }\end{array}$ & $\begin{array}{l}\text { Maximum time } \\
\text { at liberty (years) }\end{array}$ \\
\hline Male & 32 & 1 & 3.1 & 0.0 & 0 & 1.0 & 1.0 \\
\hline Female & 36 & 0 & 0.0 & & & & \\
\hline Unknown & 0 & 0 & 0.0 & & & & \\
\hline Total & 68 & 1 & 1.5 & 0.0 & 0 & 1.0 & 1.0 \\
\hline
\end{tabular}
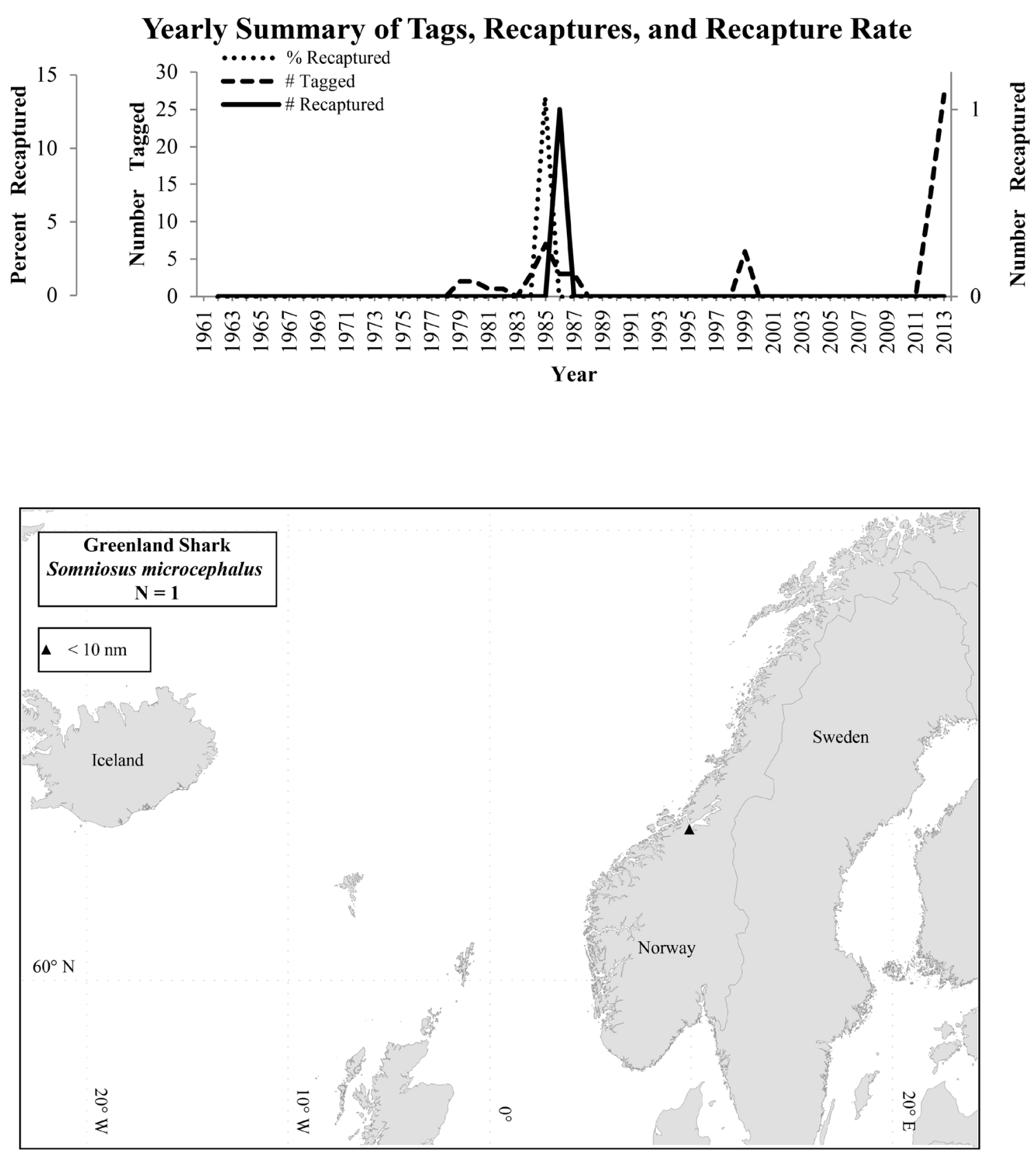

Figure 25a--Distribution of recapture locations for the Greenland shark, Somniosus microcephalus, from the NMFS Cooperative Shark Tagging Program (1962-2013). 


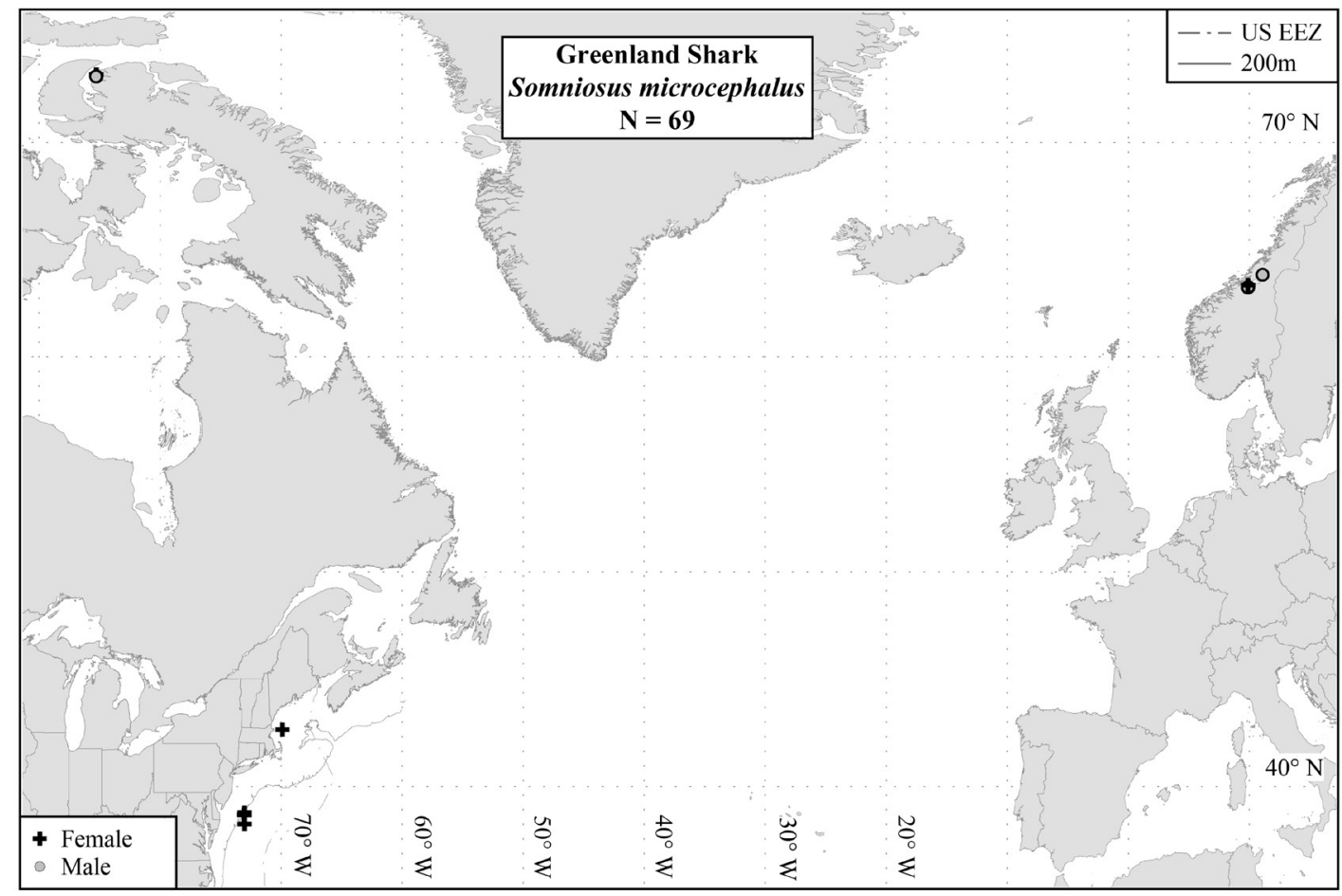

Figure 25b.-Distribution of mark/recapture locations for the Greenland shark, Somniosus microcephalus, from the NMFS Cooperative Shark Tagging Program (1962-2013).
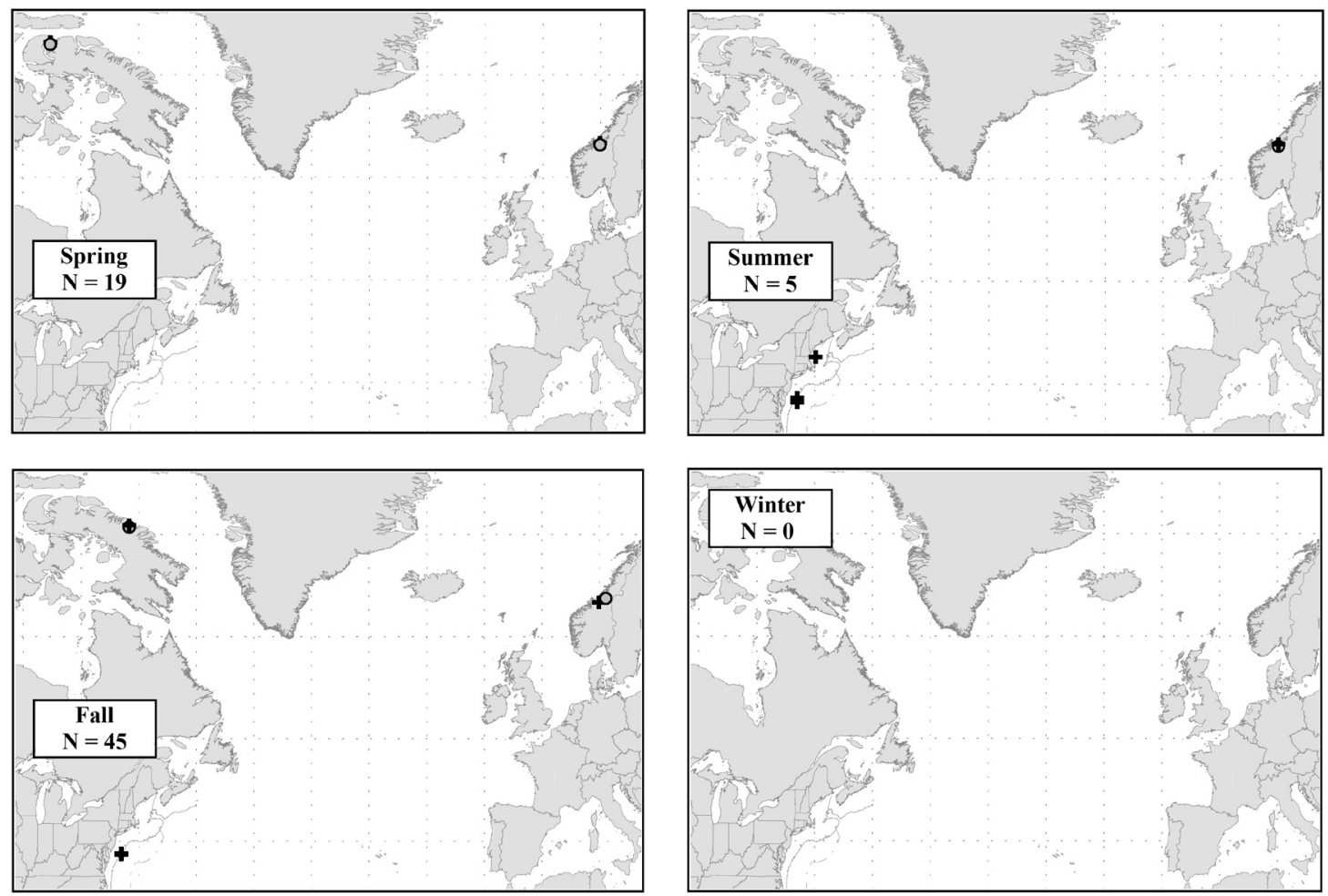

Figure 25c.-Seasonal distribution of mark/recapture locations for the Greenland shark, Somniosus microcephalus, from the NMFS Cooperative Shark Tagging Program (1962-2013). 


\section{Lemon Shark}

\begin{tabular}{|c|c|c|c|c|c|c|c|}
\hline Sex & Tags & Recaptures & $\begin{array}{c}\text { Recapture rate } \\
(\%)\end{array}$ & $\begin{array}{l}\text { Mean distance } \\
\text { traveled (nmi) }\end{array}$ & $\begin{array}{l}\text { Maximum distance } \\
\text { traveled (nmi) }\end{array}$ & $\begin{array}{l}\text { Mean time at } \\
\text { liberty (years) }\end{array}$ & $\begin{array}{l}\text { Maximum time } \\
\text { at liberty (years) }\end{array}$ \\
\hline Male & 1,348 & 147 & 10.9 & 45.0 & 494 & 1.2 & 10.9 \\
\hline Female & 1,599 & 113 & 7.1 & 19.7 & 239 & 0.8 & 5.1 \\
\hline Unknown & 284 & 17 & 6.0 & 37.4 & 286 & 1.5 & 5.2 \\
\hline Total & 3,231 & 277 & 8.6 & 34.1 & 494 & 1.1 & 10.9 \\
\hline
\end{tabular}

\section{Yearly Summary of Tags, Recaptures, and Recapture Rate}
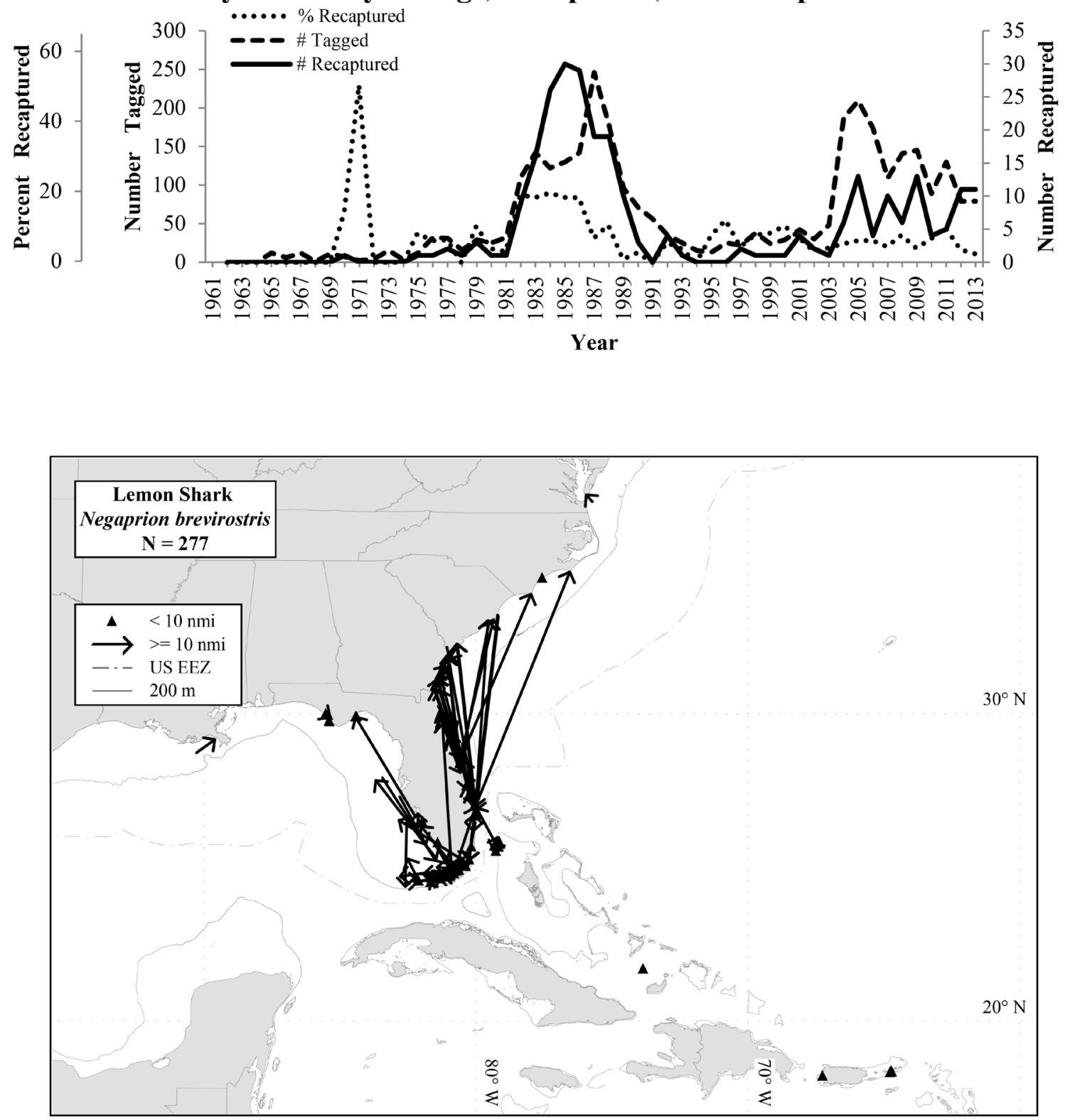

Figure 26a.-Distribution of recapture locations for the lemon shark, Negaprion brevirostris, from the NMFS Cooperative Shark Tagging Program (1962-2013). 


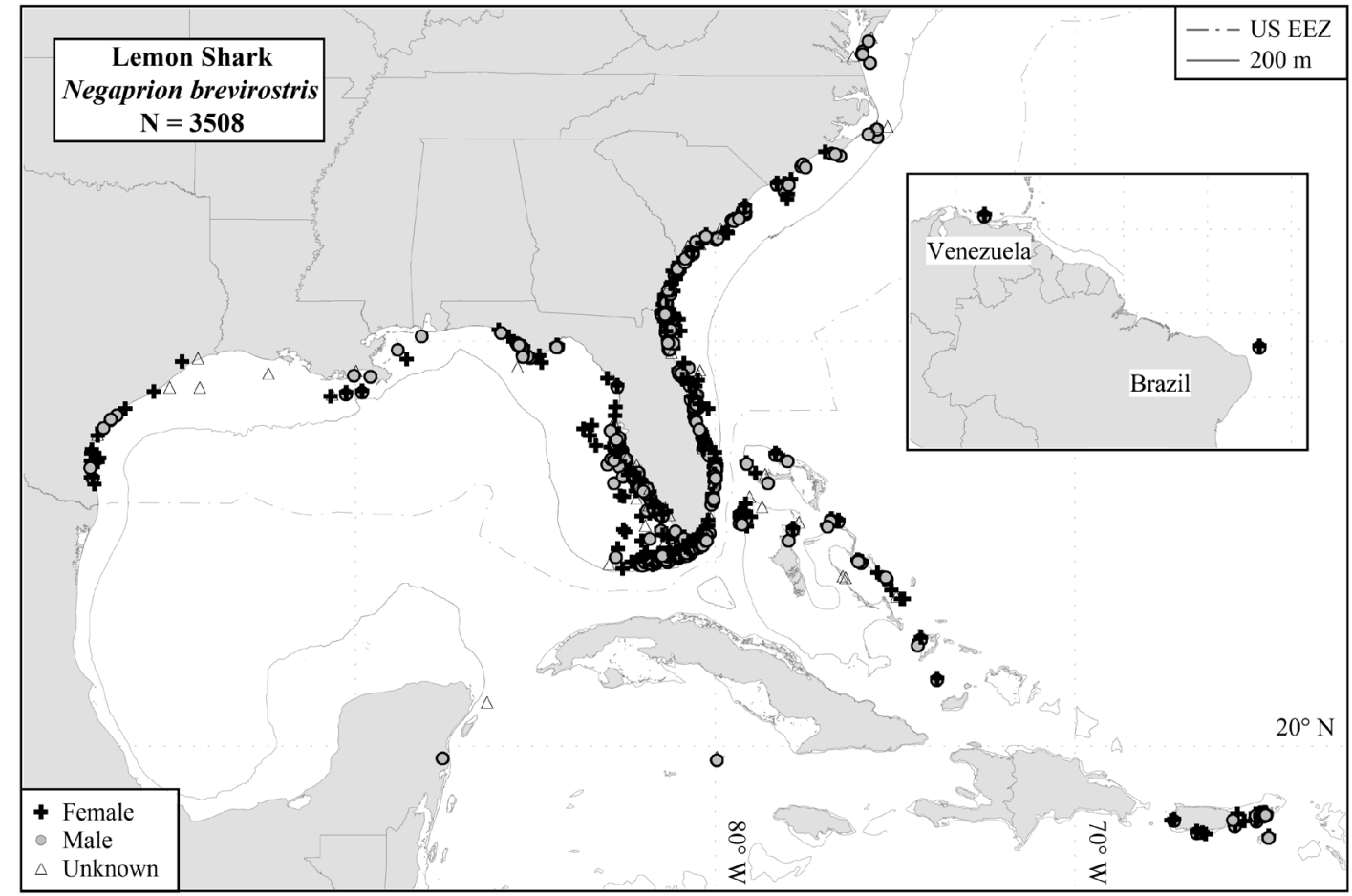

Figure 26b.-Distribution of mark/recapture locations for the lemon shark, Negaprion brevirostris, from the NMFS Cooperative Shark Tagging Program (1962-2013).
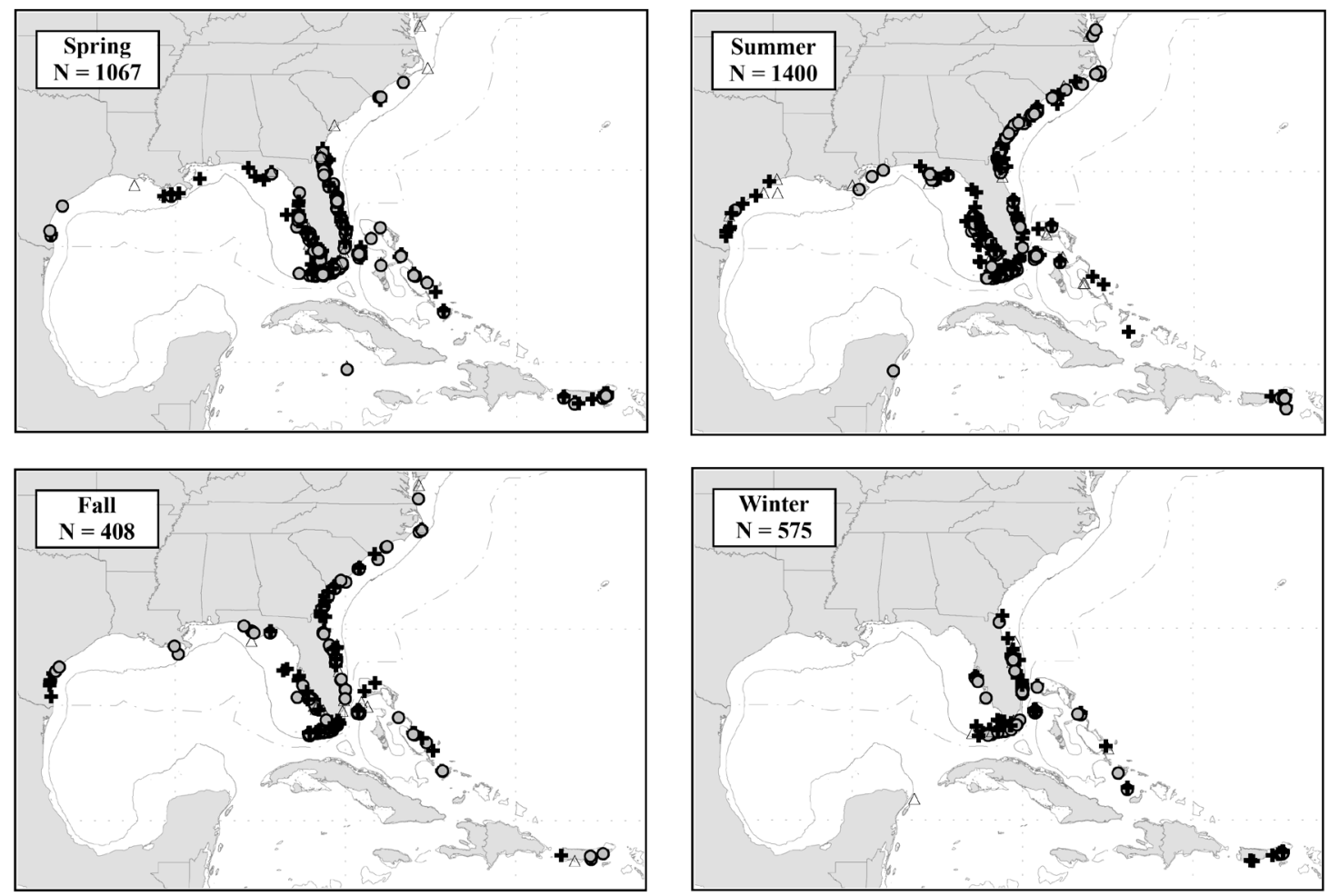

Figure 26c.- Seasonal distribution of mark/recapture locations in the western North Atlantic for the lemon shark, Negaprion brevirostris, from the NMFS Cooperative Shark Tagging Program (1962-2013). 


\section{Longfin Mako}

\begin{tabular}{|c|c|c|c|c|c|c|c|}
\hline Sex & Tags & Recaptures & $\begin{array}{c}\text { Recapture rate } \\
(\%)\end{array}$ & $\begin{array}{l}\text { Mean distance } \\
\text { traveled (nmi) }\end{array}$ & $\begin{array}{l}\text { Maximum distance } \\
\text { traveled (nmi) }\end{array}$ & $\begin{array}{l}\text { Mean time at } \\
\text { liberty (years) }\end{array}$ & $\begin{array}{l}\text { Maximum time } \\
\text { at liberty (years) }\end{array}$ \\
\hline Male & 44 & 5 & 11.4 & 835.4 & 1852 & 1.7 & 5.5 \\
\hline Female & 19 & 0 & 0.0 & & & & \\
\hline Unknown & 43 & 1 & 2.3 & 434.0 & 434 & 0.9 & 0.9 \\
\hline Total & 106 & 6 & 5.7 & 768.5 & 1852 & 1.6 & 5.5 \\
\hline
\end{tabular}

Yearly Summary of Tags, Recaptures, and Recapture Rate
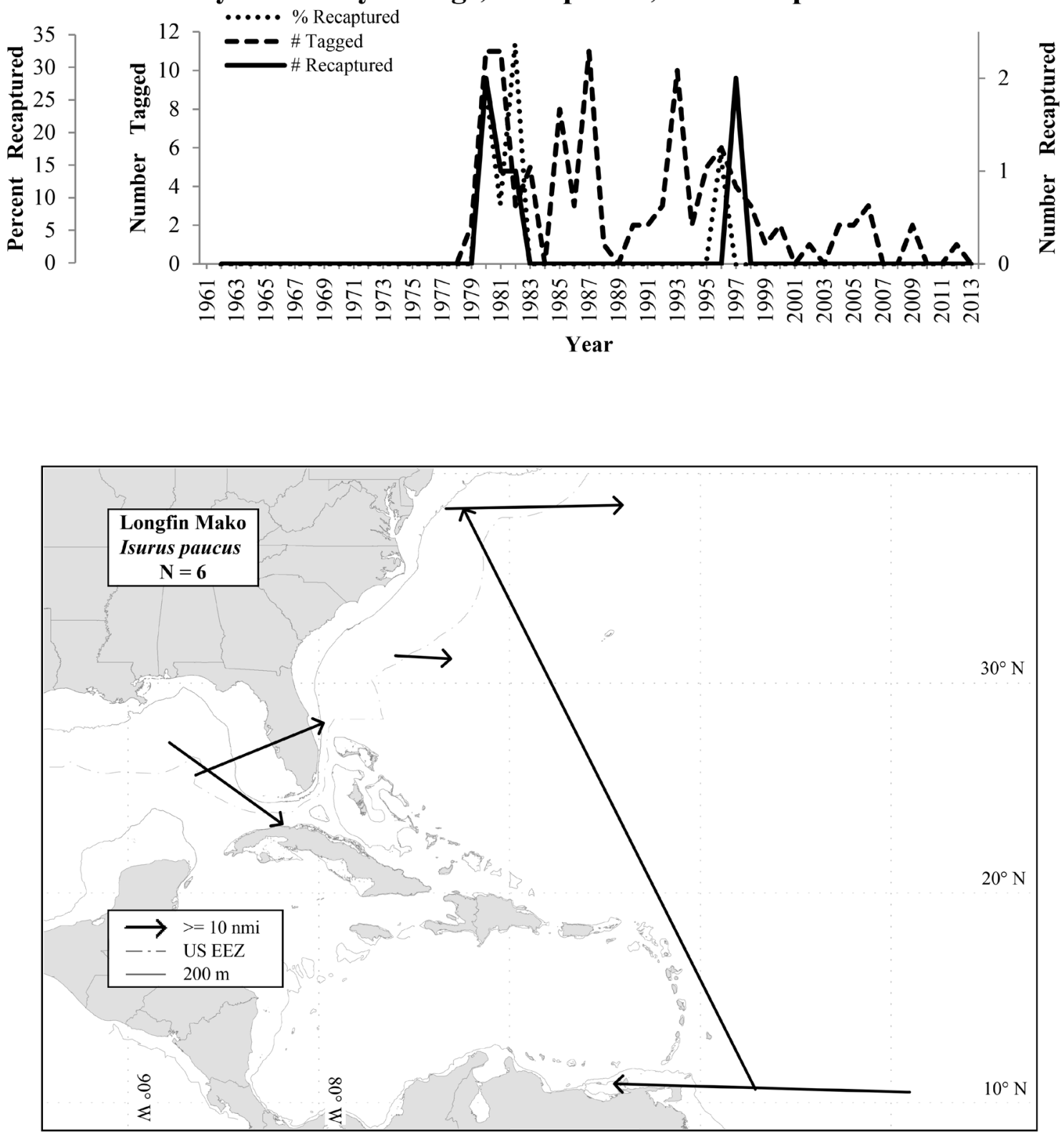

Figure 27a.-Distribution of recapture locations for the longfin mako, Isurus paucus, from the NMFS Cooperative Shark Tagging Program (1962-2013). 


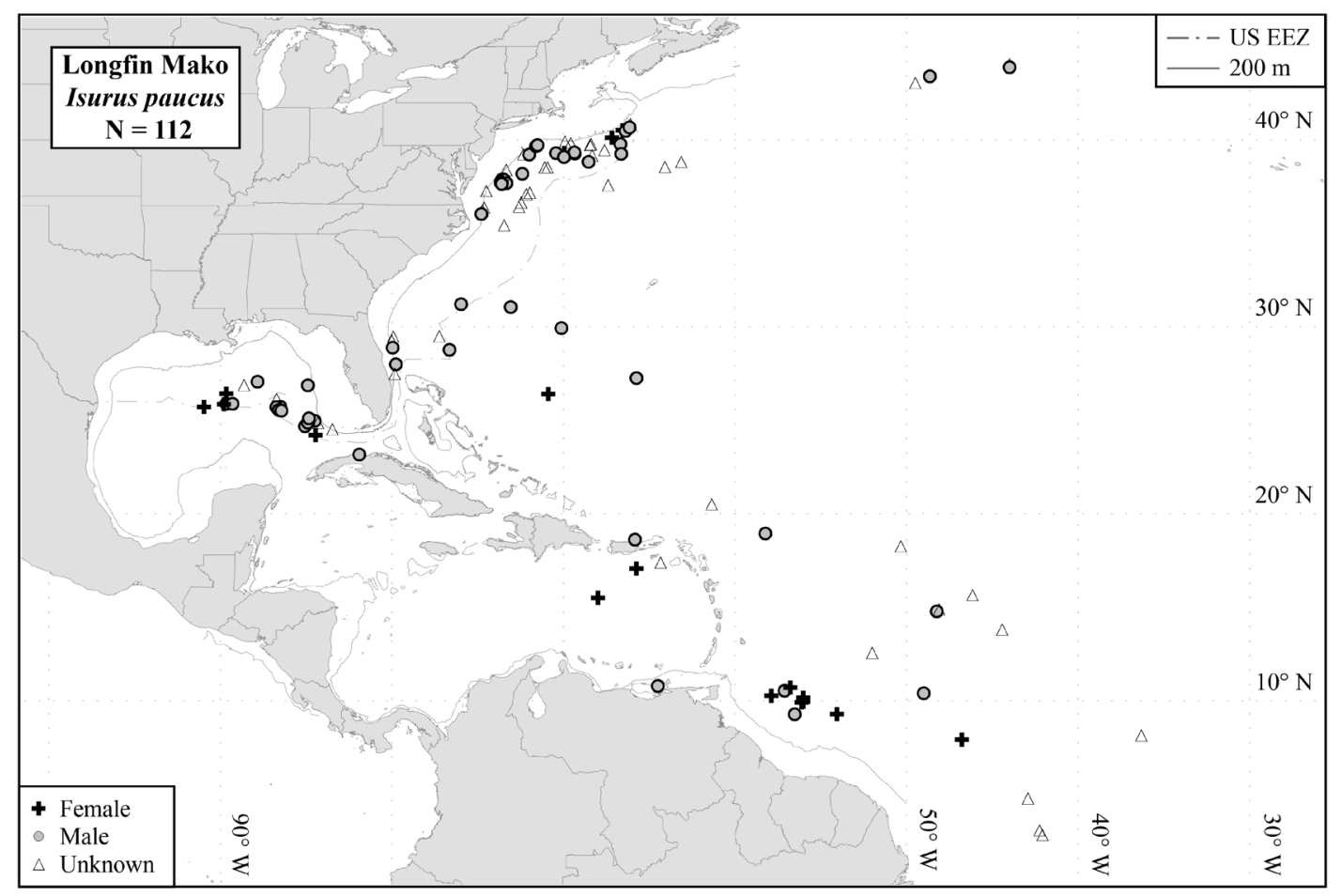

Figure 27b.-Distribution of mark/recapture locations for the longfin mako, Isurus paucus, from the NMFS Cooperative Shark Tagging Program (1962-2013).
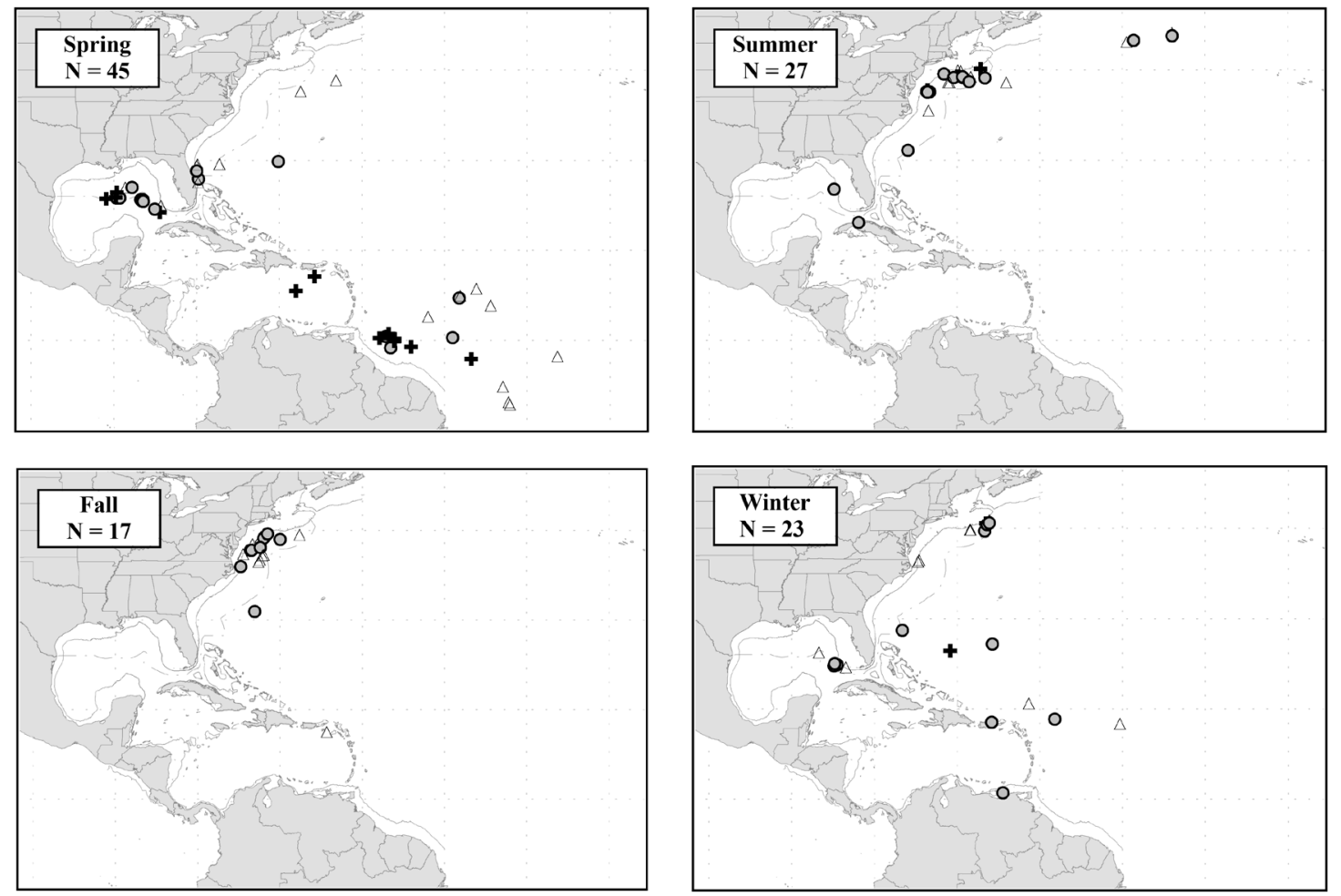

Figure 27c.- Seasonal distribution of mark/recapture locations for the longfin mako, Isurus paucus, from the NMFS Cooperative Shark Tagging Program (1962-2013). 
Night Shark

\begin{tabular}{lrcccrr}
\hline Sex & Tags & Recaptures & $\begin{array}{c}\text { Recapture rate } \\
(\%)\end{array}$ & $\begin{array}{c}\text { Mean distance } \\
\text { traveled (nmi) }\end{array}$ & $\begin{array}{c}\text { Maximum distance } \\
\text { traveled (nmi) }\end{array}$ & $\begin{array}{c}\text { Mean time at } \\
\text { liberty (years) }\end{array}$ \\
\hline Male & 96 & 4 & 4.2 & 71.0 & $\begin{array}{c}\text { Maximum time } \\
\text { at liberty (years) }\end{array}$ \\
Female & 120 & 10 & 8.3 & 582.6 & 225 & 8.6 \\
Unknown & 73 & 5 & 6.8 & 352.8 & 1,456 & 13.8 \\
Total & 289 & 19 & 6.6 & 414.4 & 789 & 4.0 \\
\hline
\end{tabular}

\section{Yearly Summary of Tags, Recaptures, and Recapture Rate}
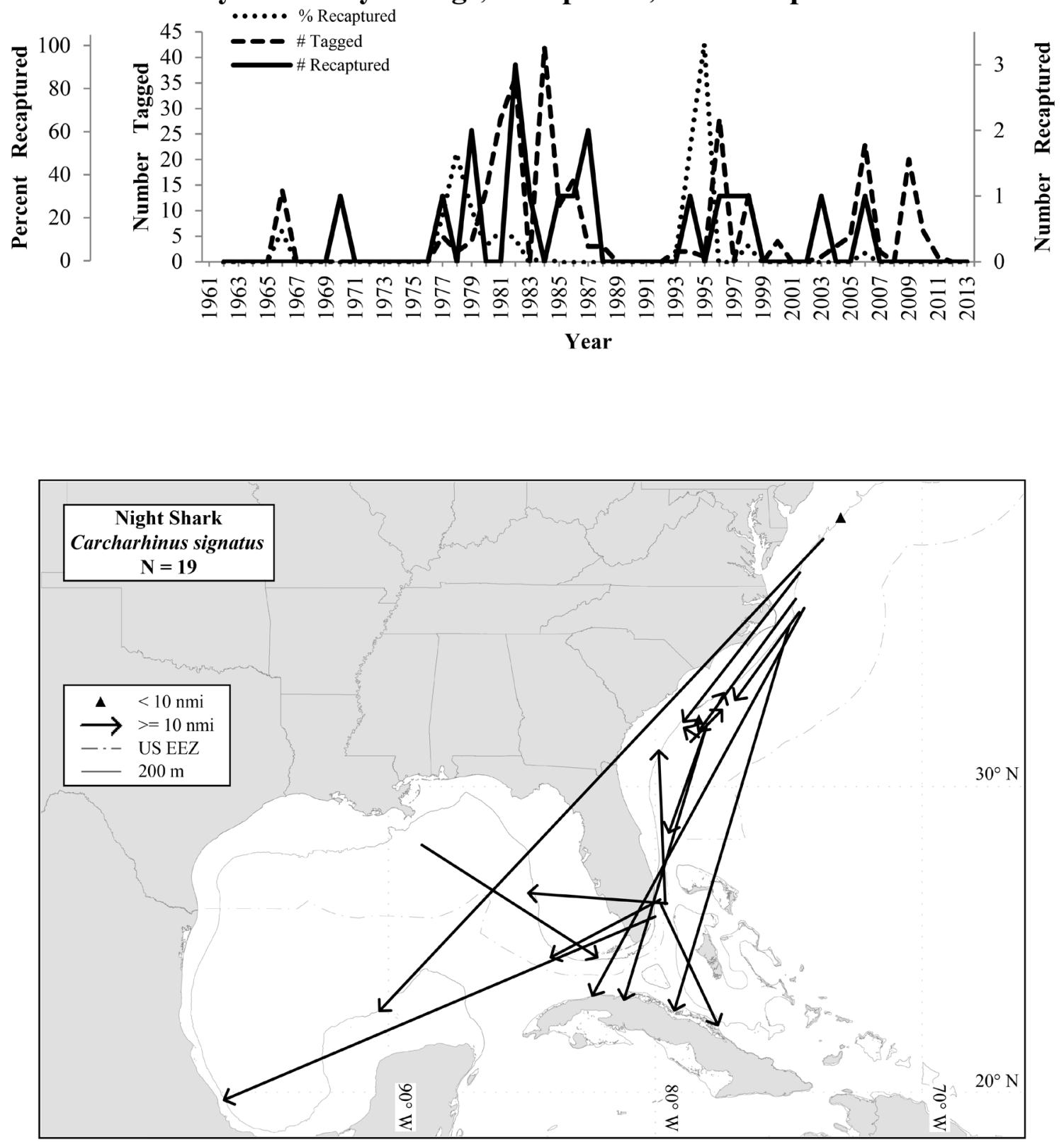

Figure 28a.-Distribution of recapture locations for the night shark, Carcharhinus signatus, from the NMFS Cooperative Shark Tagging Program (1962-2013). 


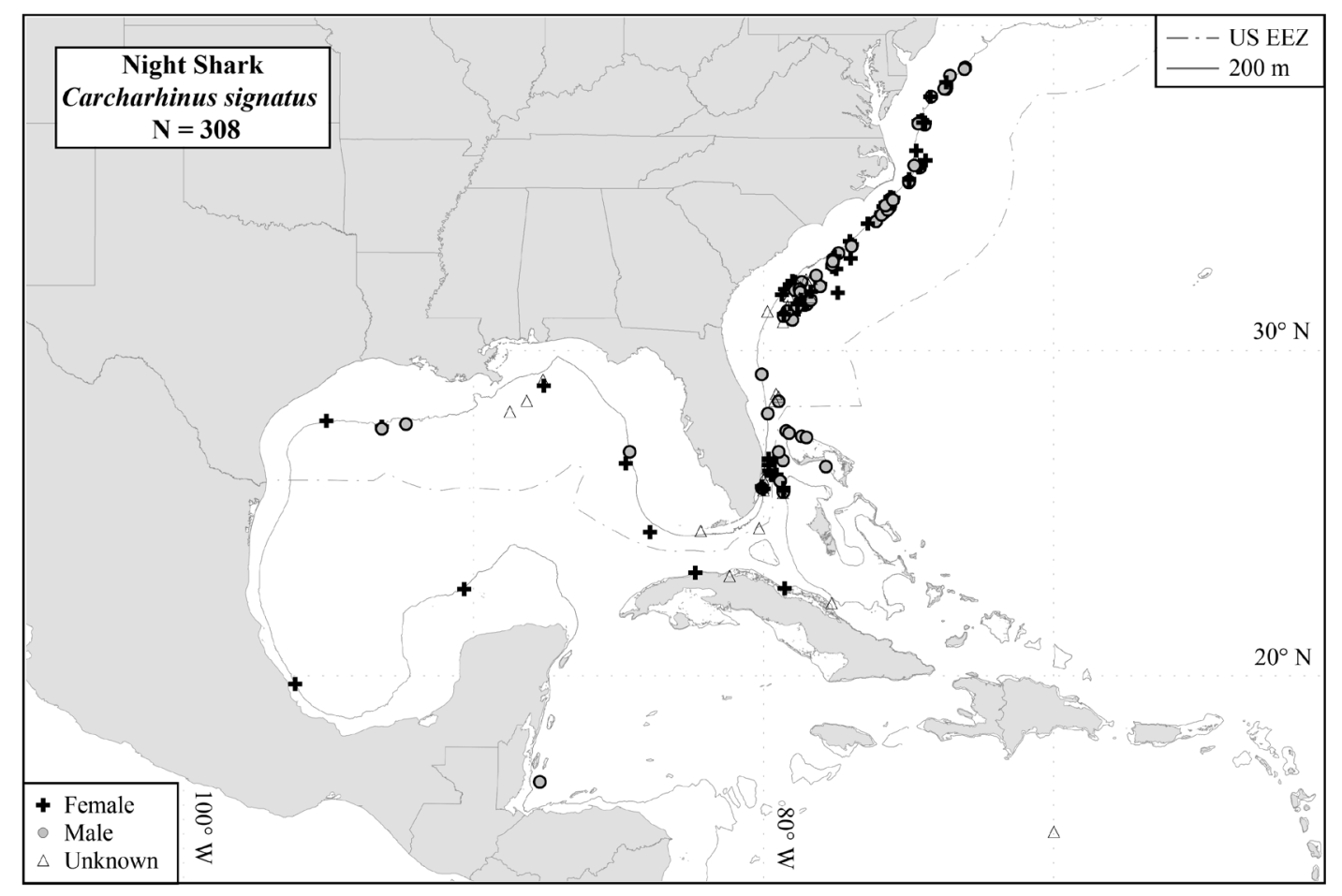

Figure 28b.-Distribution of mark/recapture locations for the night shark, Carcharhinus signatus, from the NMFS Cooperative Shark Tagging Program (1962-2013).
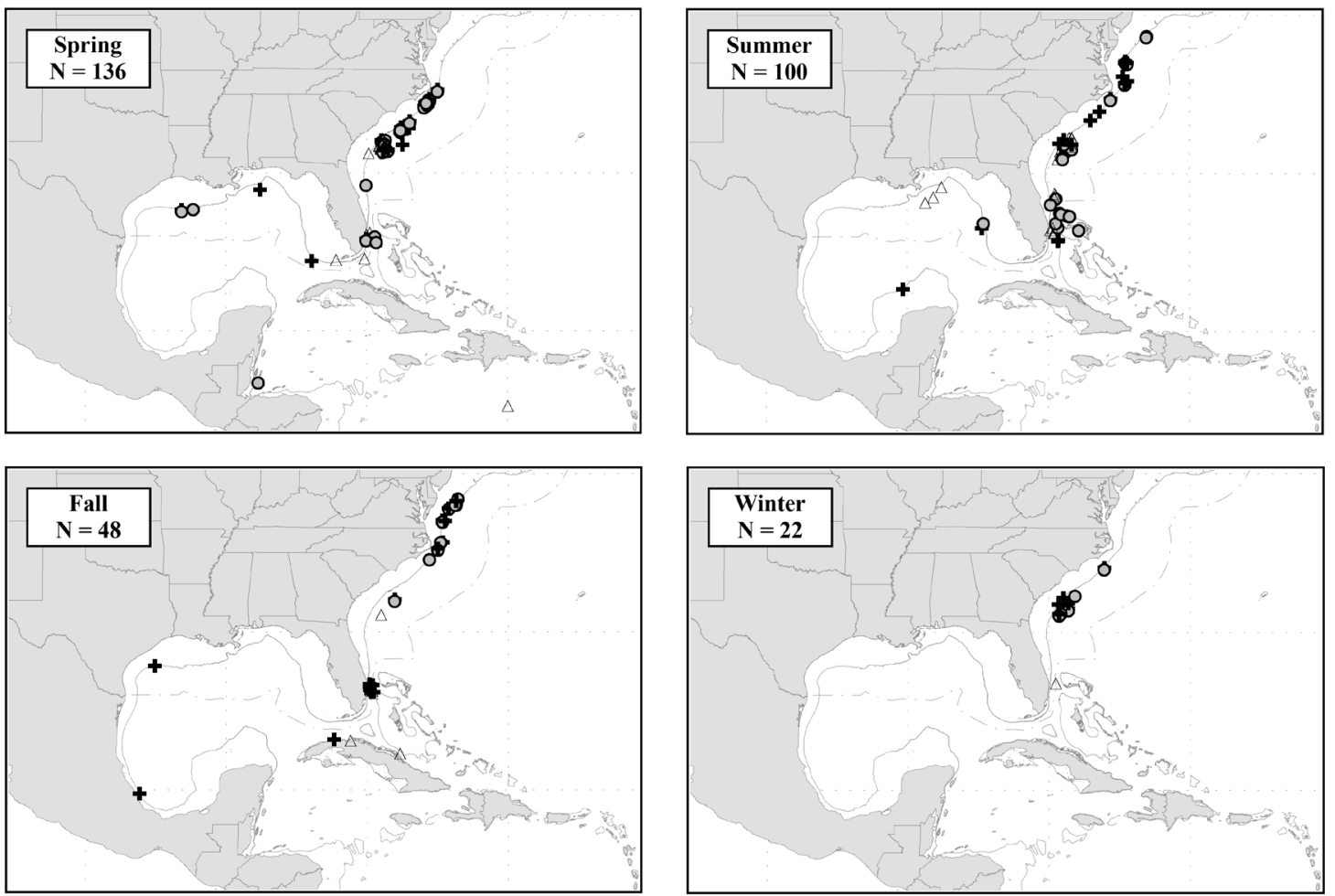

Figure 28c.- Seasonal distribution of mark/recapture locations for the night shark, Carcharhinus signatus, from the NMFS Cooperative Shark Tagging Program (1962-2013). 
Nurse Shark

\begin{tabular}{|c|c|c|c|c|c|c|c|}
\hline Sex & Tags & Recaptures & $\begin{array}{c}\text { Recapture rate } \\
(\%)\end{array}$ & $\begin{array}{l}\text { Mean distance } \\
\text { traveled (nmi) }\end{array}$ & $\begin{array}{l}\text { Maximum distance } \\
\text { traveled }(\mathrm{nmi})\end{array}$ & $\begin{array}{l}\text { Mean time at } \\
\text { liberty (years) }\end{array}$ & $\begin{array}{l}\text { Maximum time } \\
\text { at liberty (years) }\end{array}$ \\
\hline Male & 1,003 & 78 & 7.8 & 19.3 & 297 & 1.2 & 7.8 \\
\hline Female & 944 & 84 & 8.9 & 13.6 & 385 & 1.4 & 11.6 \\
\hline Unknown & 239 & 13 & 5.4 & 31.5 & 225 & 1.2 & 6.9 \\
\hline Total & 2,186 & 175 & 8.0 & 17.3 & 385 & 1.3 & 11.6 \\
\hline
\end{tabular}

Yearly Summary of Tags, Recaptures, and Recapture Rate
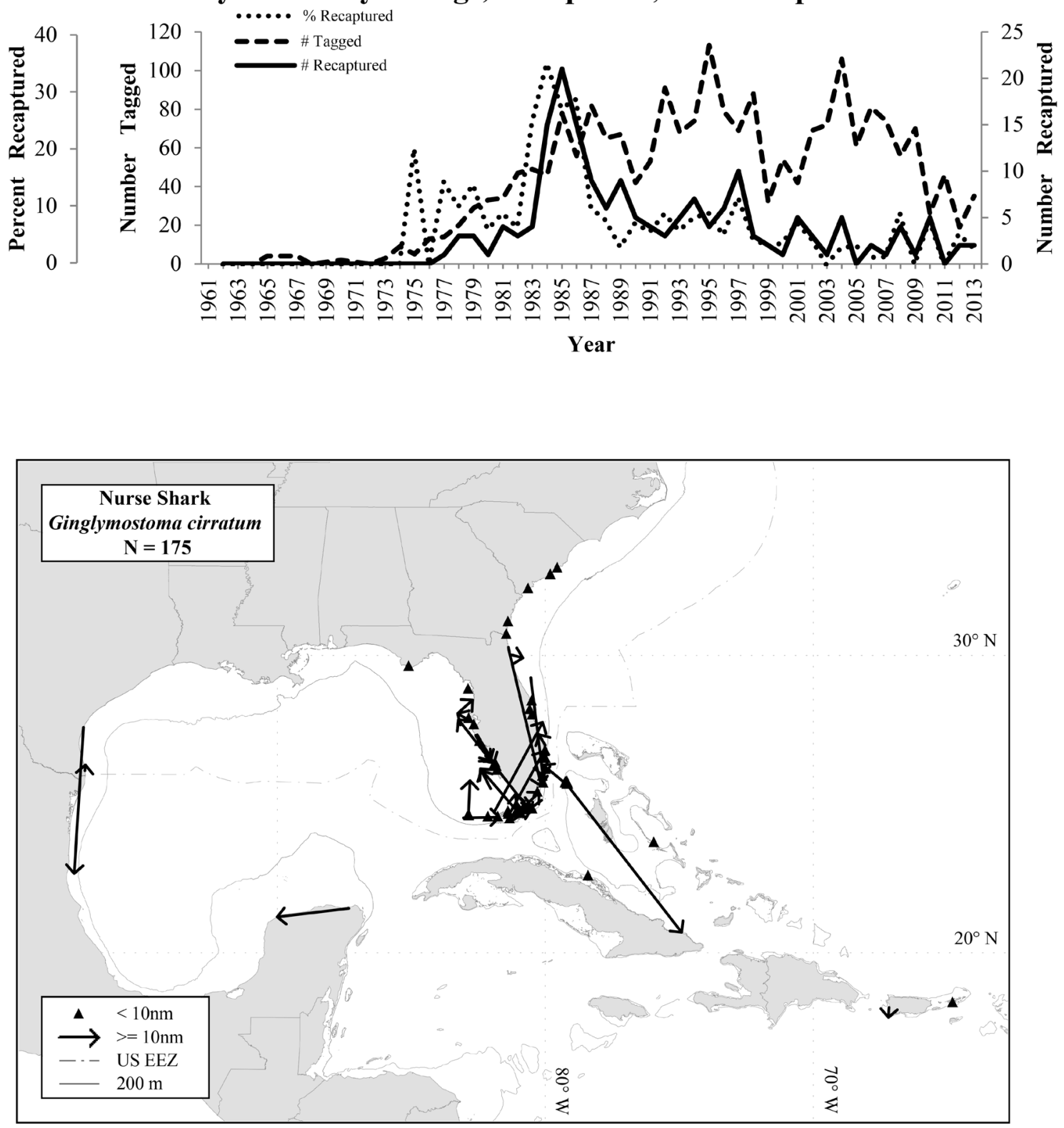

Figure 29a.-Distribution of recapture locations for the nurse shark, Ginglymostoma cirratum, from the NMFS Cooperative Shark Tagging Program (1962-2013). 


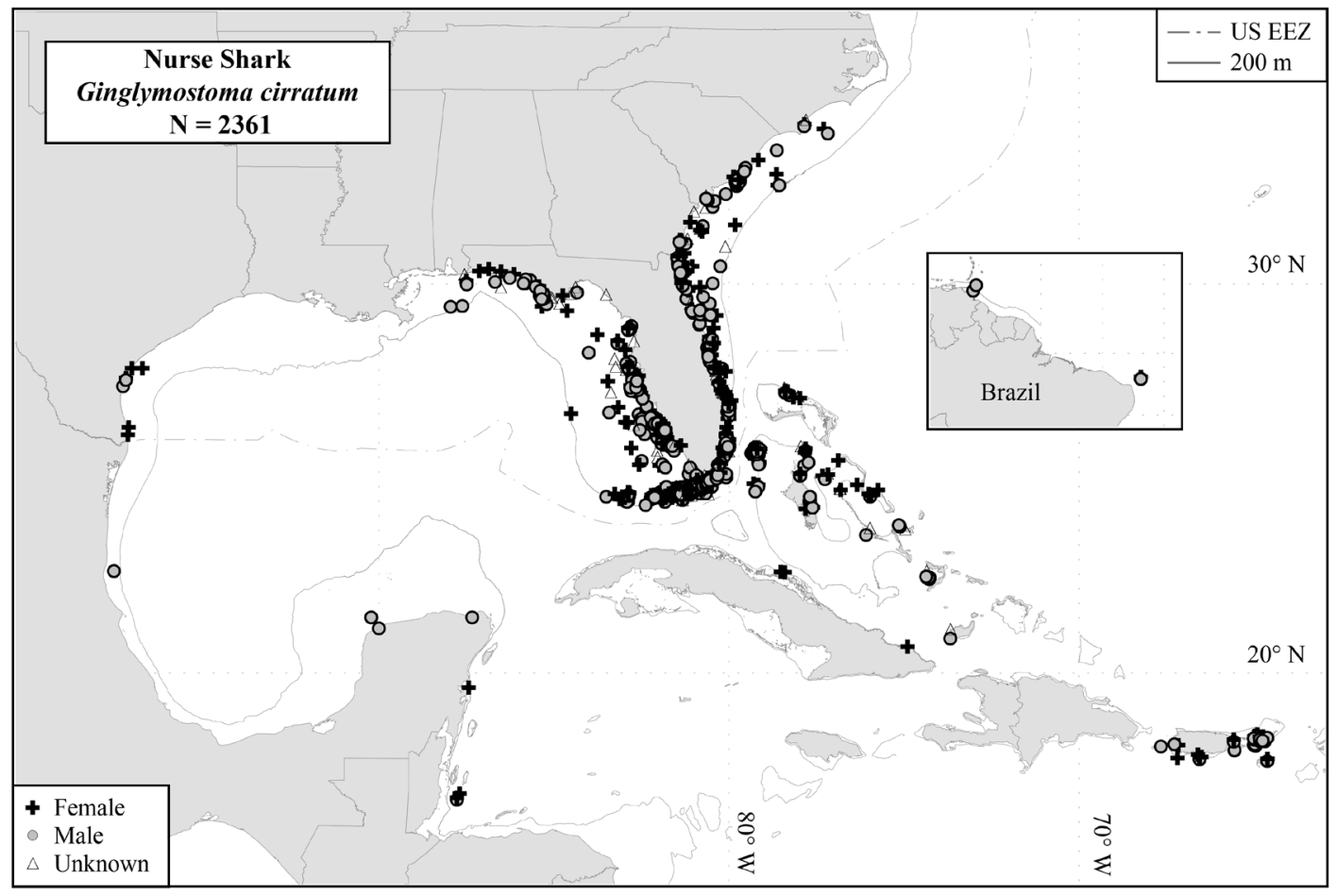

Figure 29b.-Distribution of mark/recapture locations for the nurse shark, Ginglymostoma cirratum, from the NMFS Cooperative Shark Tagging Program (1962-2013).
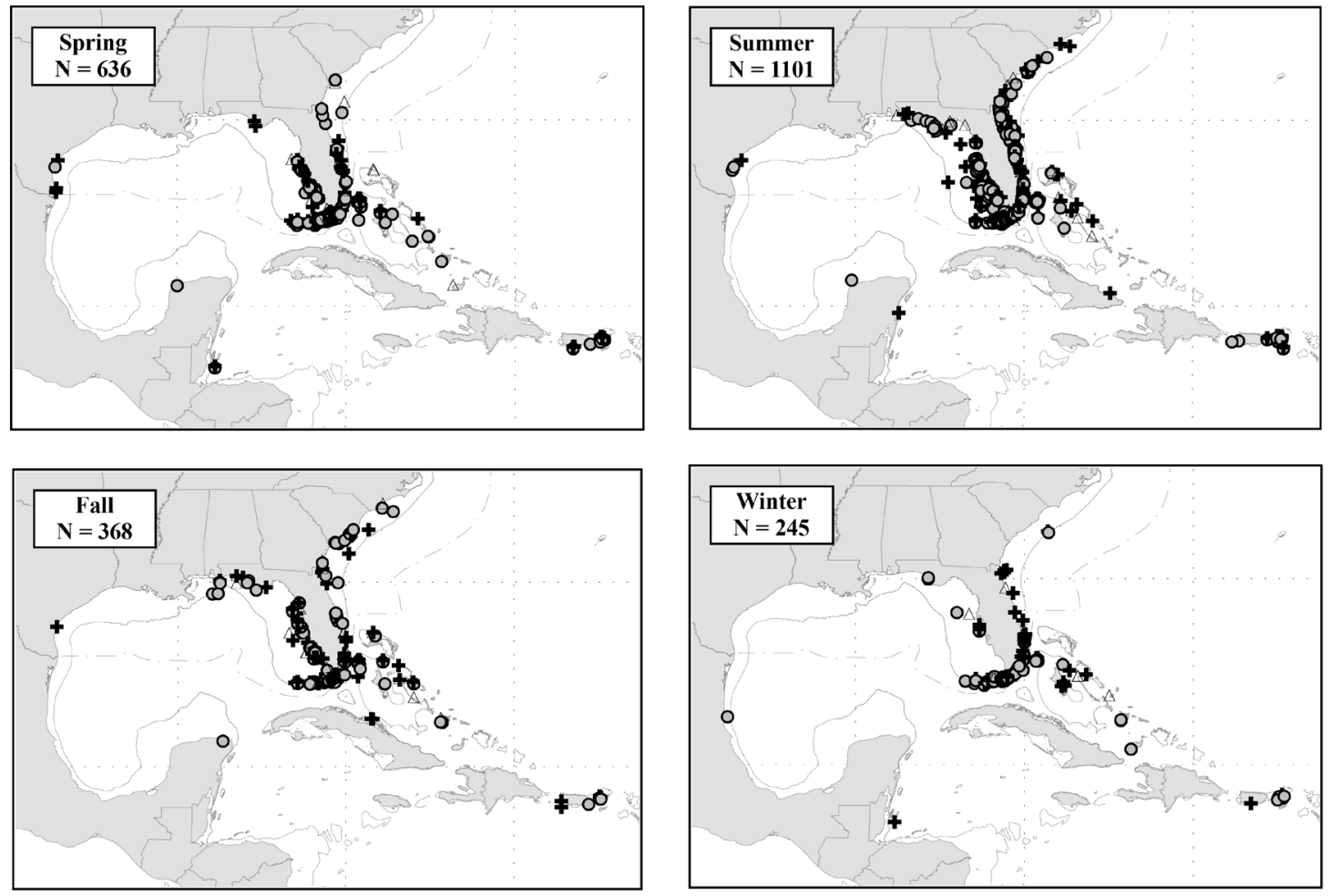

Figure 29c.- Seasonal distribution of mark/recapture locations in the western North Atlantic for the nurse shark, Ginglymostoma cirratum, from the NMFS Cooperative Shark Tagging Program (1962-2013). 


\section{Oceanic Whitetip Shark}

\begin{tabular}{lccccrr}
\hline Sex & Tags & Recaptures & $\begin{array}{c}\text { Recapture rate } \\
(\%)\end{array}$ & $\begin{array}{c}\text { Mean distance } \\
\text { traveled (nmi) }\end{array}$ & $\begin{array}{c}\text { Maximum distance } \\
\text { traveled (nmi) }\end{array}$ & $\begin{array}{c}\text { Mean time at } \\
\text { liberty (years) }\end{array}$ \\
\hline Male & 152 & 1 & 0.7 & 555.0 & 555 & $\begin{array}{c}\text { Maximum time } \\
\text { at liberty (years) }\end{array}$ \\
Female & 216 & 5 & 2.3 & 443.4 & 998 & 0.3 \\
Unknown & 275 & 2 & 0.7 & 625.0 & 1,226 & 0.3 \\
Total & 643 & 8 & 1.2 & 502.8 & 1,226 & 0.3 \\
\hline
\end{tabular}

\section{Yearly Summary of Tags, Recaptures, and Recapture Rate}
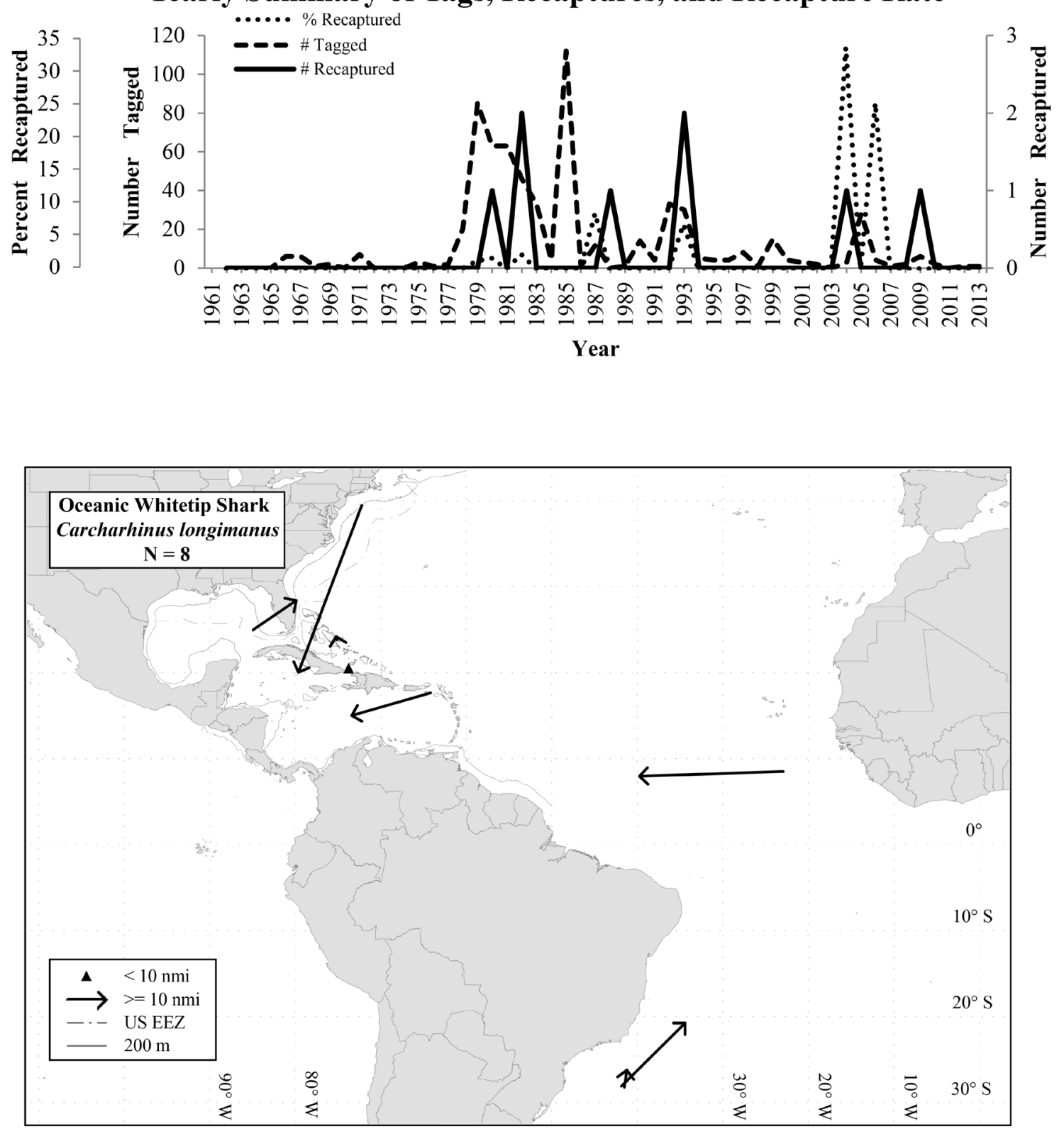

Figure 30a.-Distribution of recapture locations for the oceanic whitetip shark, Carcharhinus longimanus, from the NMFS Cooperative Shark Tagging Program (1962-2013). 


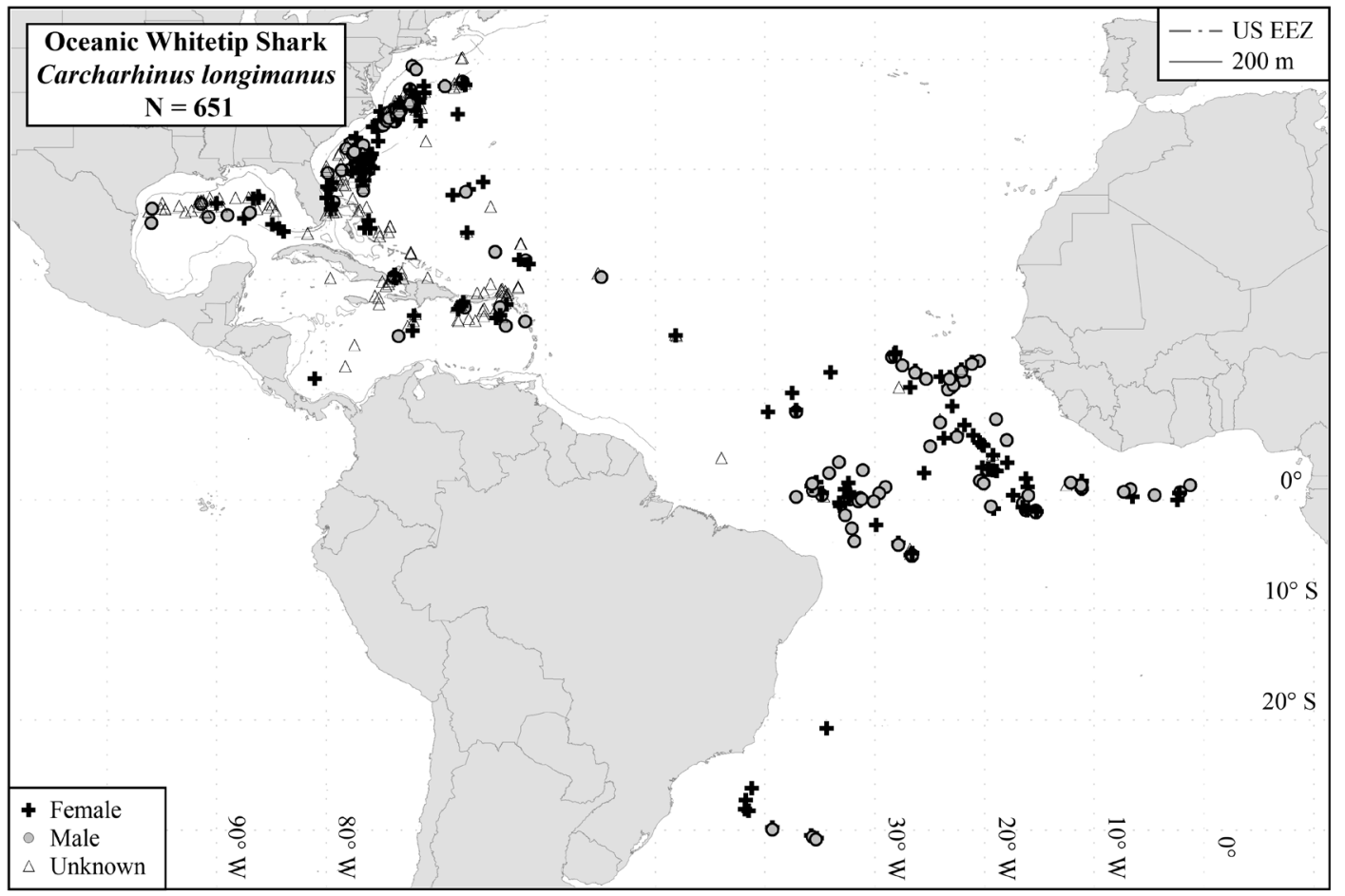

Figure 30b.-Distribution of mark/recapture locations for the oceanic whitetip shark, Carcharhinus longimanus, from the NMFS Cooperative Shark Tagging Program (1962-2013).
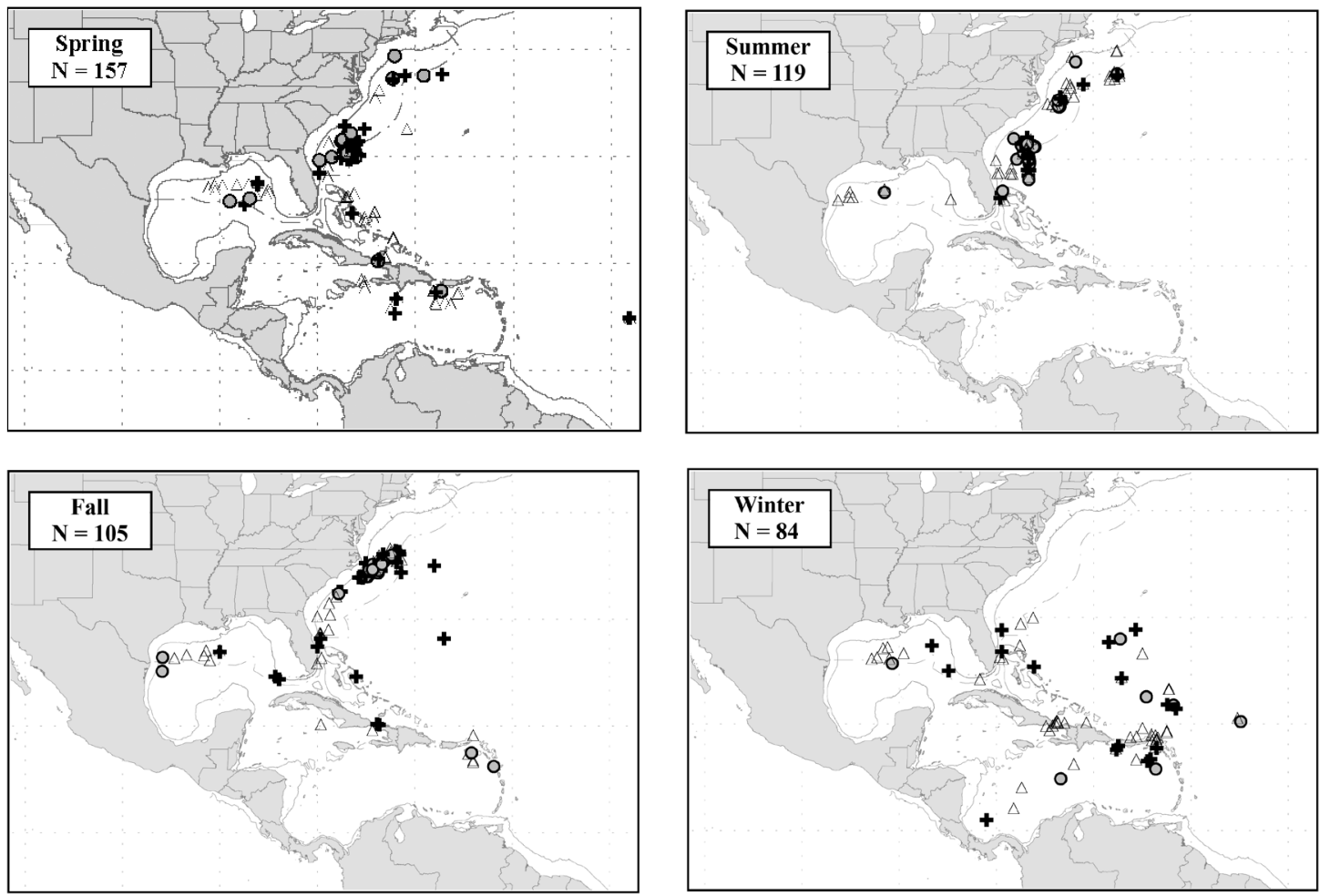

Figure 30c.- Seasonal distribution of mark/recapture locations in the western North Atlantic for the oceanic whitetip shark, Carcharhinus longimanus, from the NMFS Cooperative Shark Tagging Program (1962-2013). 


\section{Porbeagle}

\begin{tabular}{lcccccc}
\hline Sex & Tags & Recaptures & $\begin{array}{c}\text { Recapture rate } \\
(\%)\end{array}$ & $\begin{array}{c}\text { Mean distance } \\
\text { traveled (nmi) }\end{array}$ & $\begin{array}{c}\text { Maximum distance } \\
\text { traveled (nmi) }\end{array}$ & $\begin{array}{c}\text { Mean time at } \\
\text { liberty (years) }\end{array}$ \\
\hline Male & 727 & 73 & 10.0 & 215.5 & $\begin{array}{c}\text { Maximum time } \\
\text { at liberty (years) }\end{array}$ \\
Female & 727 & 80 & 11.0 & 245.0 & 778 & 3.0 \\
Unknown & 300 & 25 & 8.3 & 216.5 & 11.0 & 3.1 \\
Total & 1,754 & 178 & 10.1 & 228.8 & 1,216 & 3.8 \\
\hline
\end{tabular}

\section{Yearly Summary of Tags, Recaptures, and Recapture Rate}

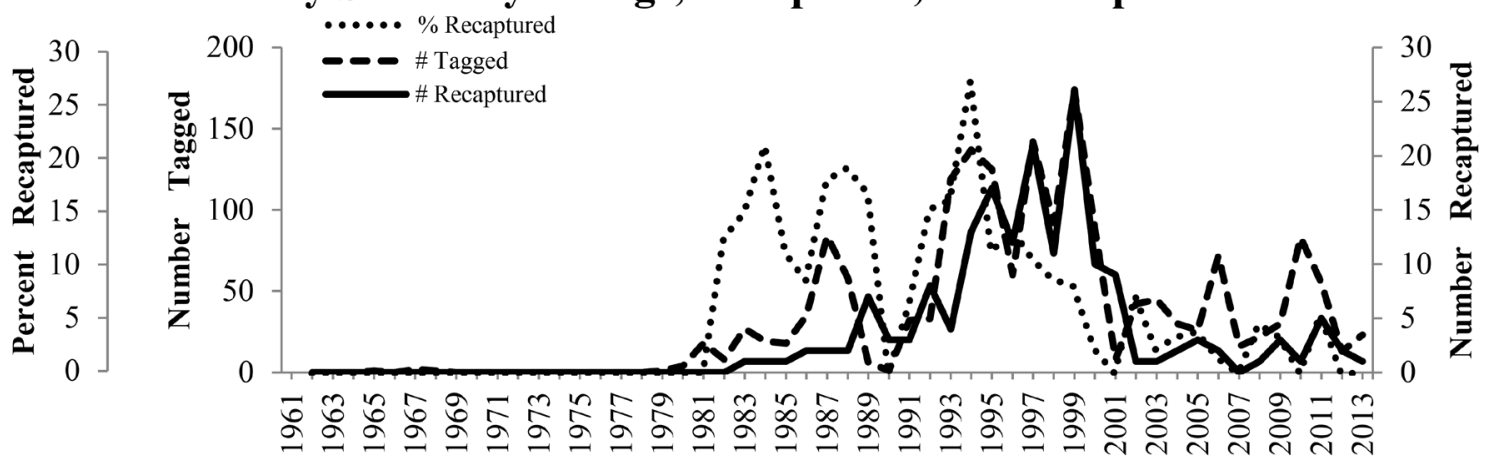

Year

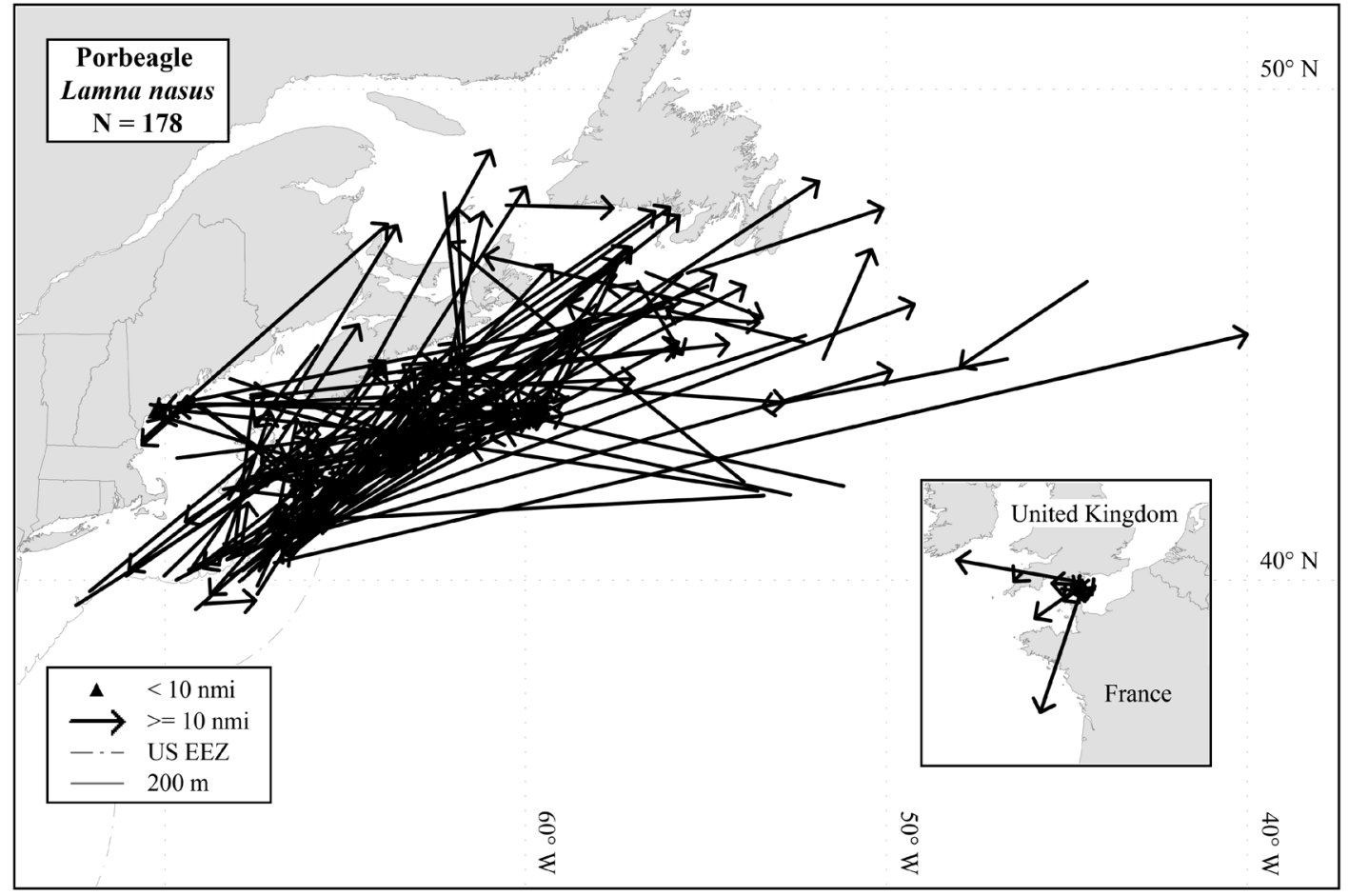

Figure 31a.-Distribution of recapture locations for the porbeagle, Lamna nasus, from the NMFS Cooperative Shark Tagging Program (1962-2013). 


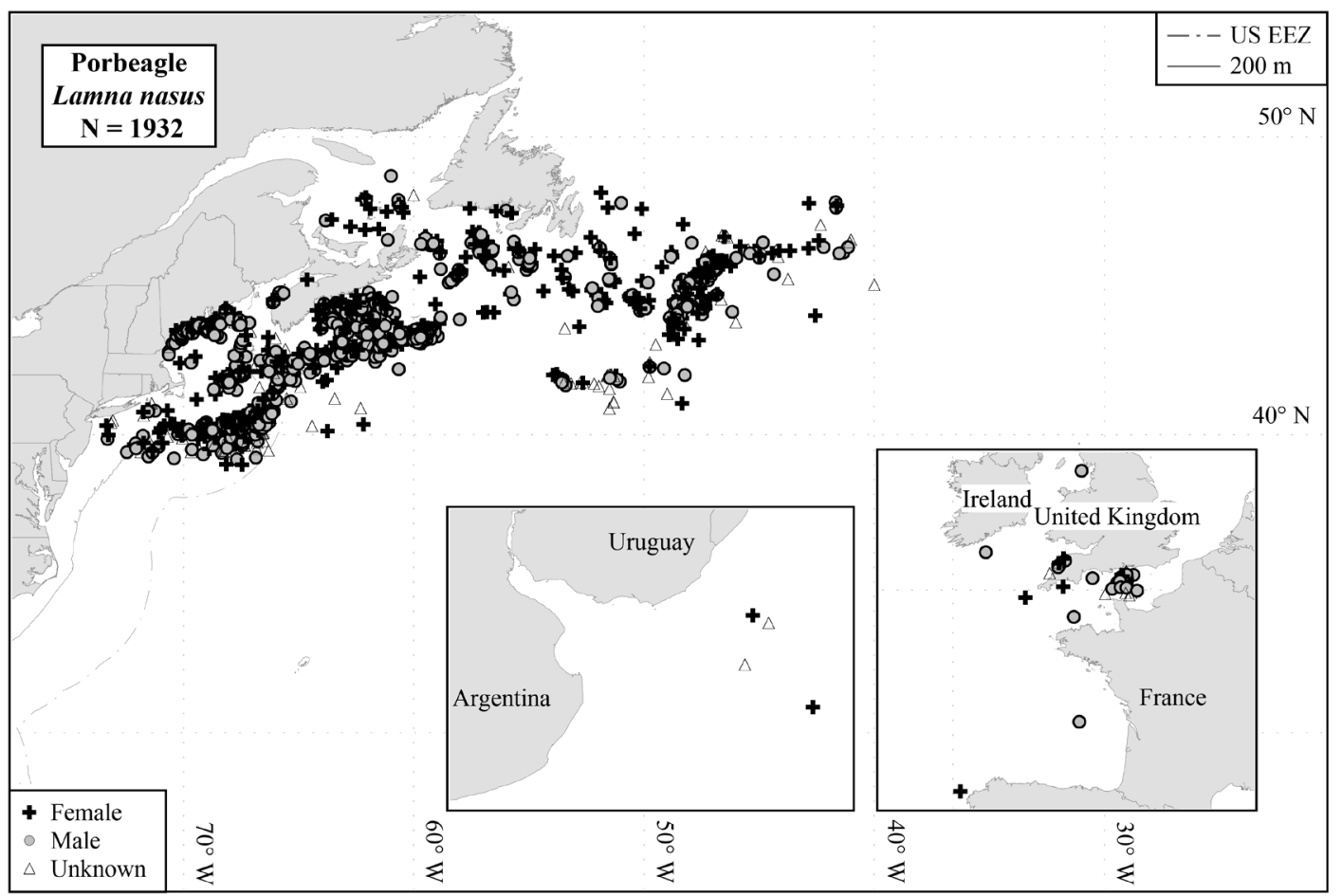

Figure 31b.-Distribution of mark/recapture locations for the porbeagle, Lamna nasus, from the NMFS Cooperative Shark Tagging Program (1962-2013).
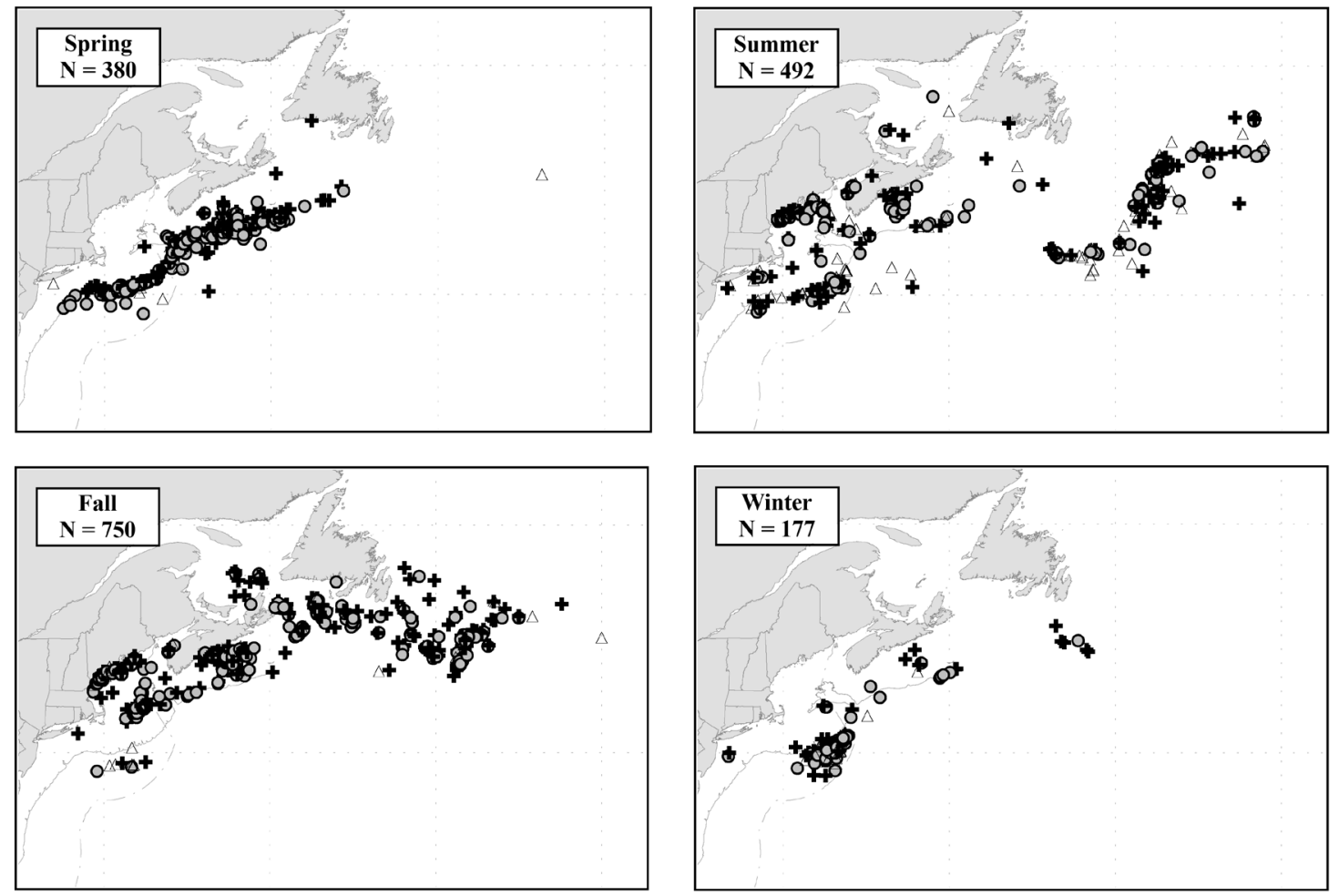

Figure 31c.- Seasonal distribution of mark/recapture locations in the western North Atlantic for the porbeagle, Lamna nasus, from the NMFS Cooperative Shark Tagging Program (1962-2013). 


\section{Reef Shark}

\begin{tabular}{lcccccc}
\hline Sex & Tags & Recaptures & $\begin{array}{c}\text { Recapture rate } \\
(\%)\end{array}$ & $\begin{array}{c}\text { Mean distance } \\
\text { traveled (nmi) }\end{array}$ & $\begin{array}{c}\text { Maximum distance } \\
\text { traveled (nmi) }\end{array}$ & $\begin{array}{c}\text { Mean time at } \\
\text { liberty (years) }\end{array}$ \\
\hline Male & 271 & 11 & 4.1 & 3.1 & $\begin{array}{c}\text { Maximum time } \\
\text { at liberty (years) }\end{array}$ \\
Female & 414 & 11 & 2.7 & 2.9 & 16 & 3.0 \\
Unknown & 83 & 2 & 2.4 & 1.0 & 26 & 9.2 \\
Total & 768 & 24 & 3.1 & 2.8 & 2.4 & 0 \\
\hline
\end{tabular}

\section{Yearly Summary of Tags, Recaptures, and Recapture Rate}

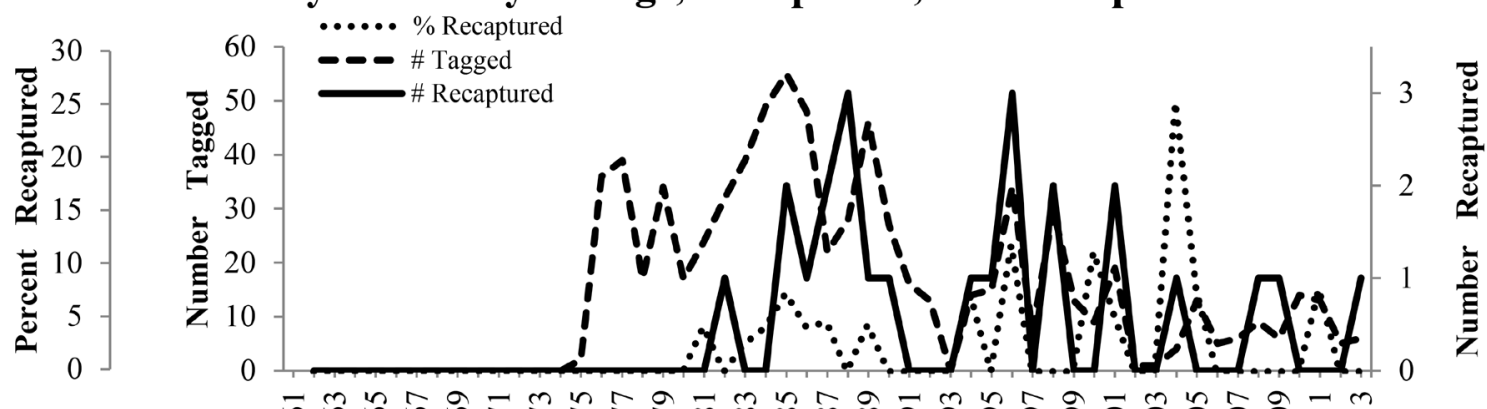

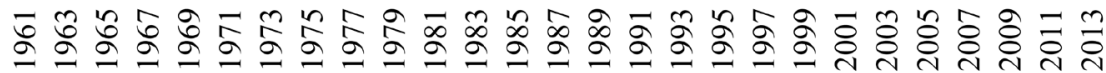

Year

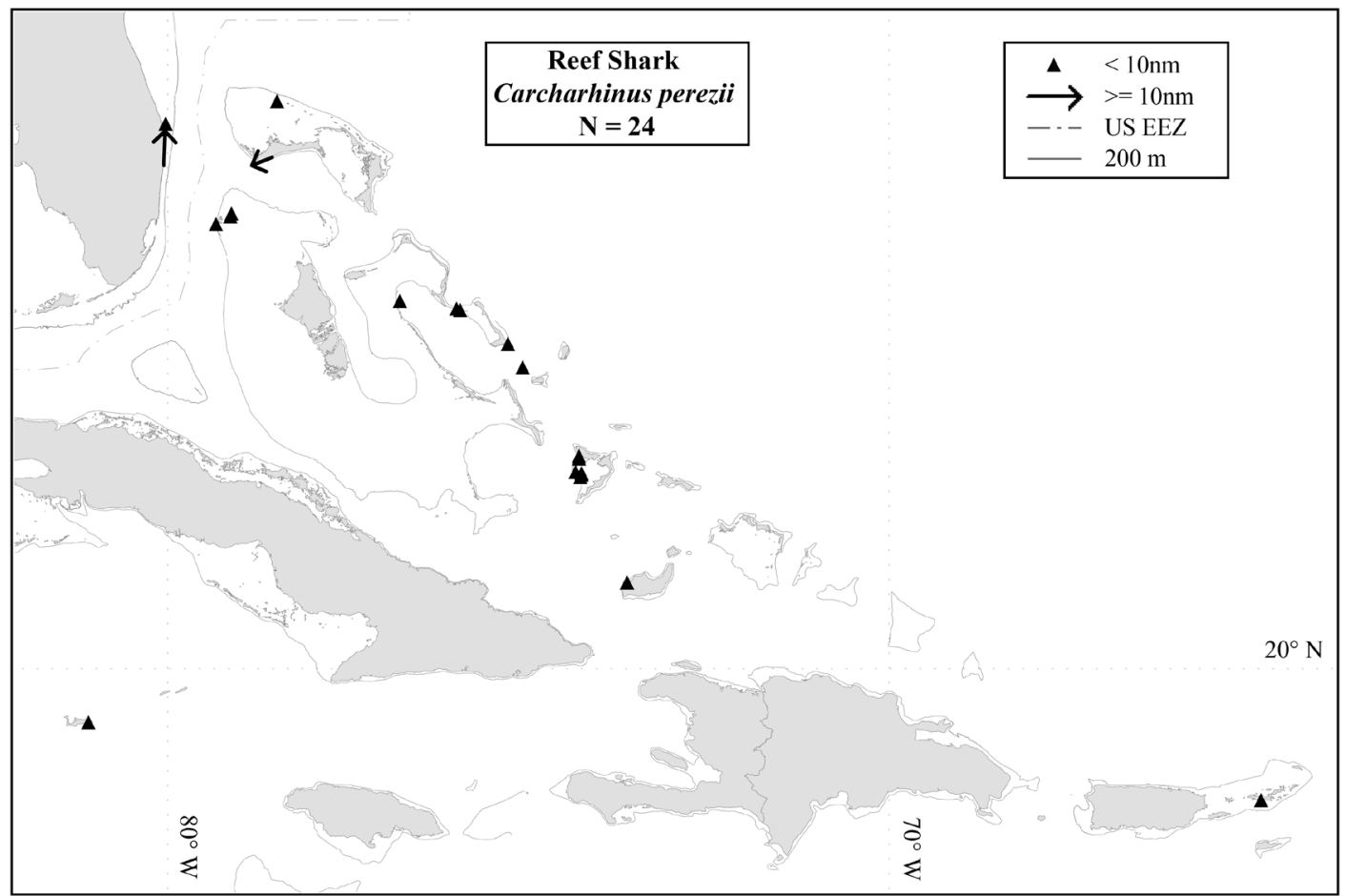

Figure 32a.-Distribution of recapture locations for the reef shark, Carcharhinus perezii, from the NMFS Cooperative Shark Tagging Program (1962-2013). 


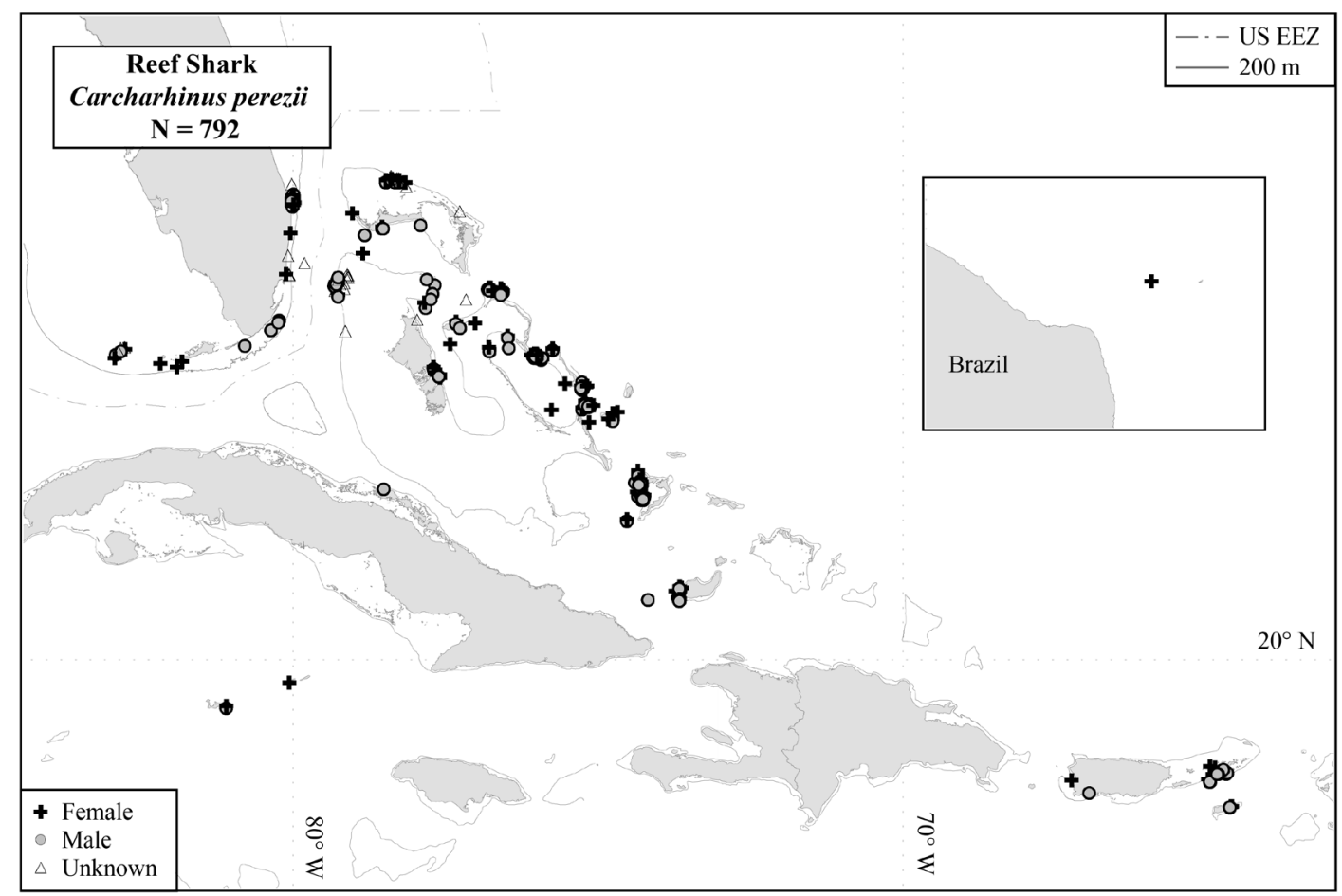

Figure 32b.-Distribution of mark/recapture locations for the reef shark, Carcharhinus perezii, from the NMFS Cooperative Shark Tagging Program (1962-2013).
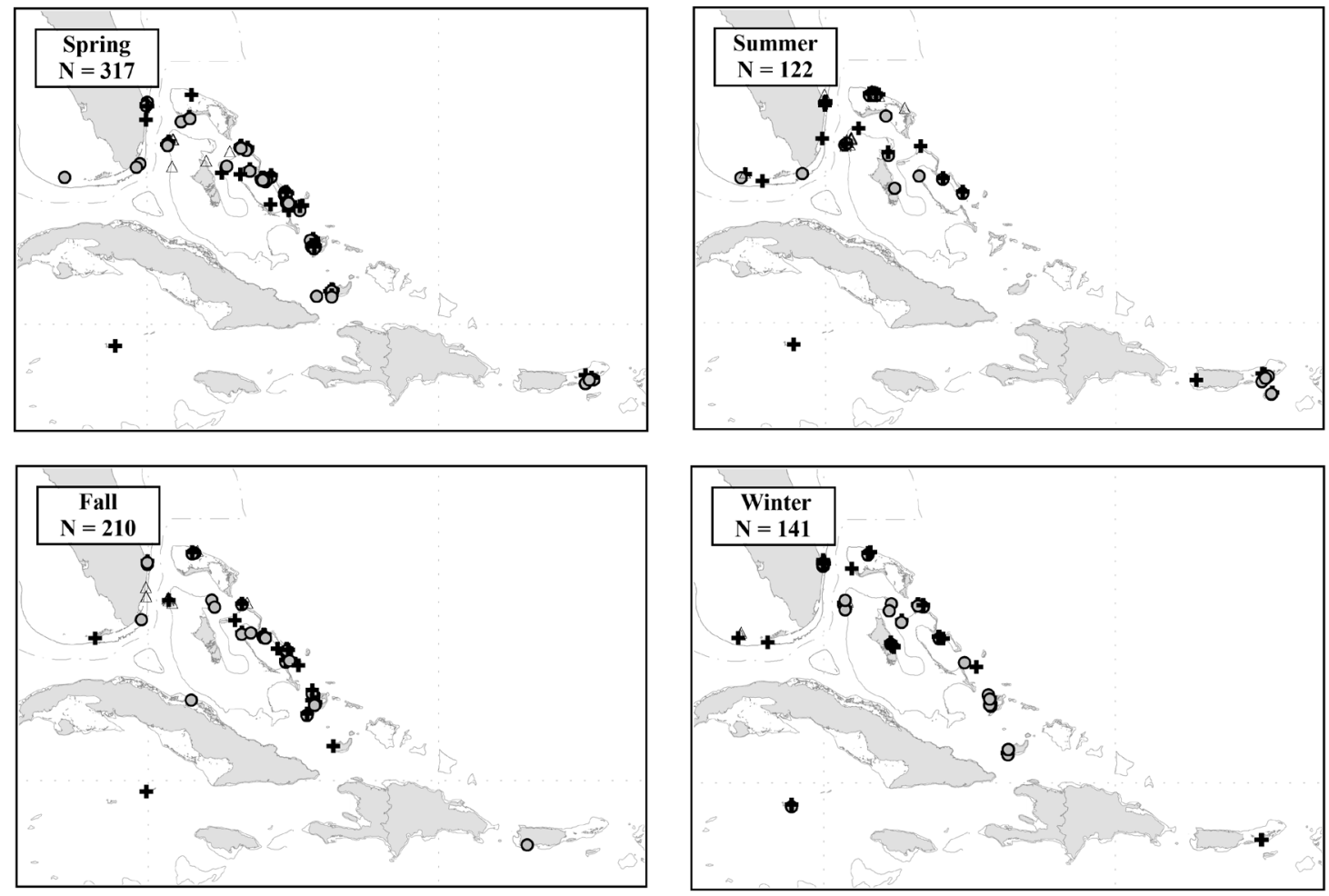

Figure 32c. - Seasonal distribution of mark/recapture locations in the western North Atlantic for the reef shark, Carcharhinus perezii, from the NMFS Cooperative Shark Tagging Program (1962-2013). 


\section{Sandbar Shark}

\begin{tabular}{|c|c|c|c|c|c|c|c|}
\hline Sex & Tags & Recaptures & $\begin{array}{c}\text { Recapture rate } \\
(\%)\end{array}$ & $\begin{array}{l}\text { Mean distance } \\
\text { traveled (nmi) }\end{array}$ & $\begin{array}{l}\text { Maximum distance } \\
\text { traveled (nmi) }\end{array}$ & $\begin{array}{l}\text { Mean time at } \\
\text { liberty (years) }\end{array}$ & $\begin{array}{l}\text { Maximum time } \\
\text { at liberty (years) }\end{array}$ \\
\hline Male & 12,470 & 545 & 4.4 & 354.0 & 2,039 & 2.8 & 24.9 \\
\hline Female & 19,363 & 784 & 4.0 & 410.5 & 2,031 & 3.0 & 26.9 \\
\hline Unknown & 4,096 & 145 & 3.5 & 784.2 & 2,038 & 5.0 & 27.8 \\
\hline Total & 35,929 & 1474 & 4.1 & 423.4 & 2,039 & 3.1 & 27.8 \\
\hline
\end{tabular}

Yearly Summary of Tags, Recaptures, and Recapture Rate

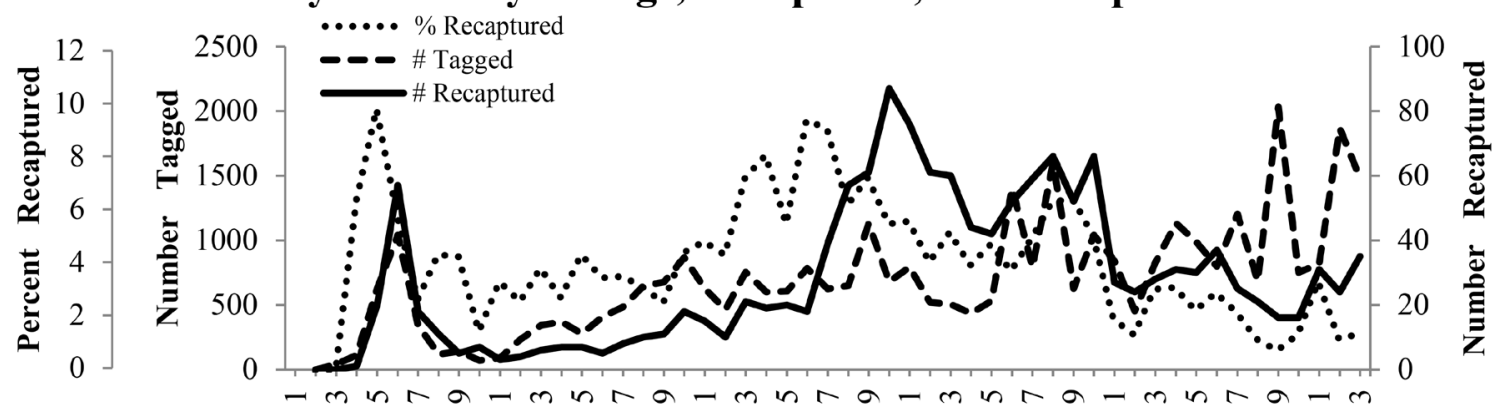

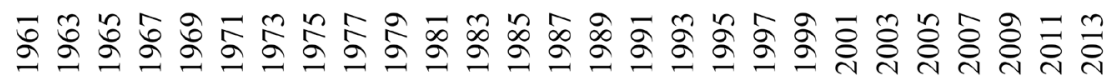

Year

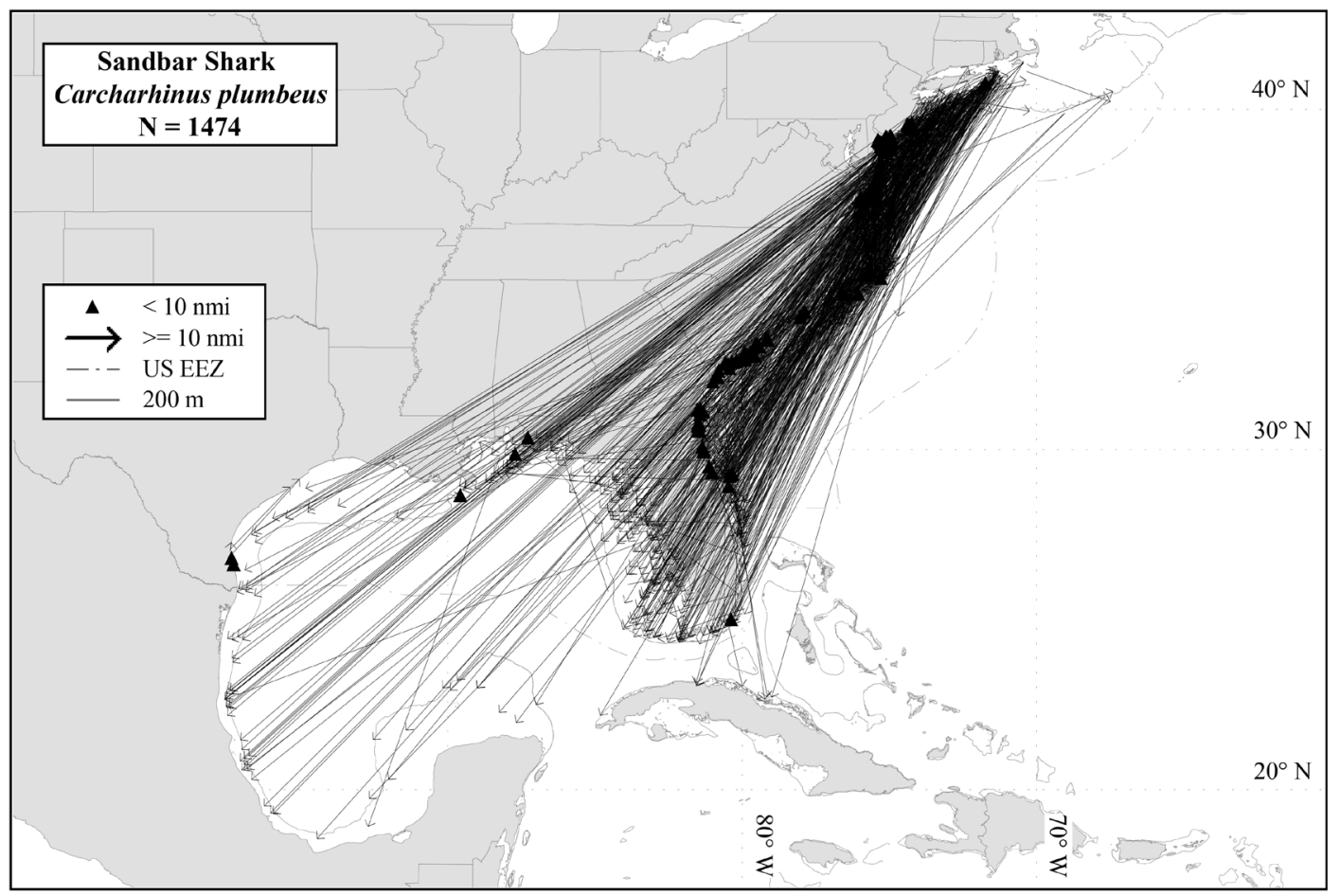

Figure 33a.-Distribution of recapture locations for the sandbar shark, Carcharhinus plumbeus, from the NMFS Cooperative Shark Tagging Program (1962-2013). 


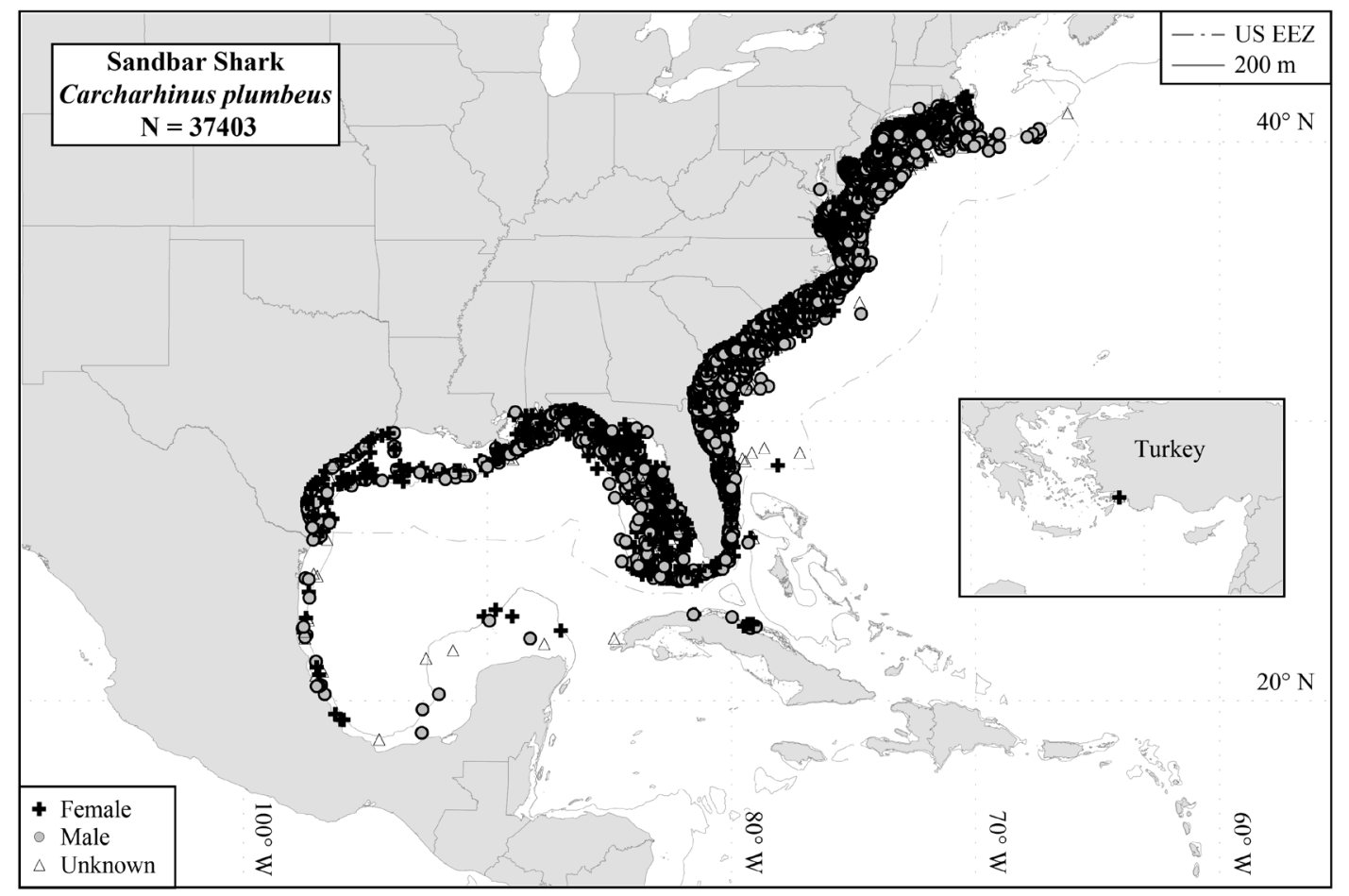

Figure 33b.-Distribution of mark/recapture locations for the sandbar shark, Carcharhinus plumbeus, from the NMFS Cooperative Shark Tagging Program (1962-2013).
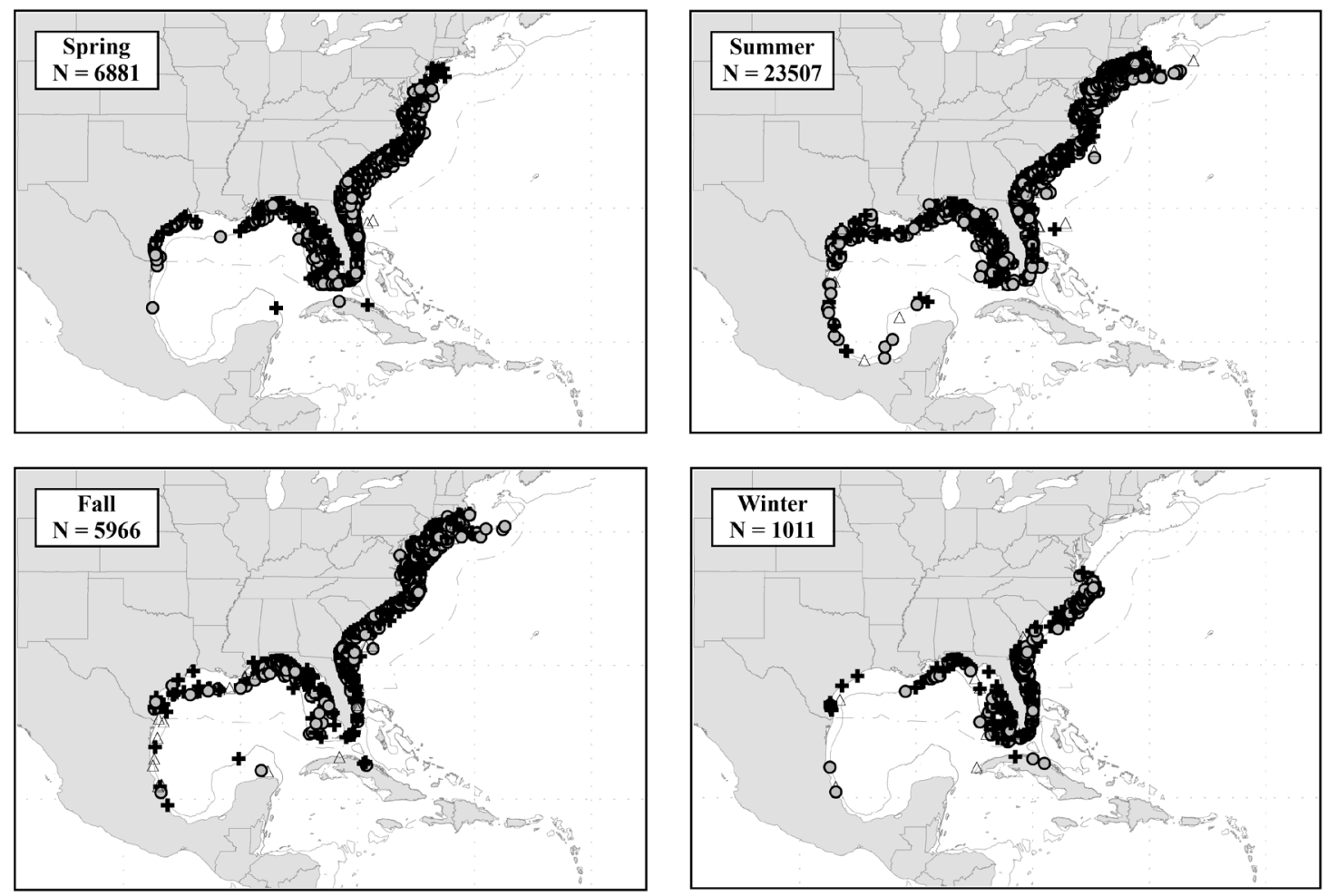

Figure 33c.- Seasonal distribution of mark/recapture locations in the western North Atlantic for the sandbar shark, Carcharhinus plumbeus, from the NMFS Cooperative Shark Tagging Program (1962-2013). 


\section{Sand Tiger}

\begin{tabular}{|c|c|c|c|c|c|c|c|}
\hline Sex & Tags & Recaptures & $\begin{array}{c}\text { Recapture rate } \\
(\%)\end{array}$ & $\begin{array}{l}\text { Mean distance } \\
\text { traveled (nmi) }\end{array}$ & $\begin{array}{l}\text { Maximum distance } \\
\text { traveled }(\mathrm{nmi})\end{array}$ & $\begin{array}{l}\text { Mean time at } \\
\text { liberty (years) }\end{array}$ & $\begin{array}{l}\text { Maximum time } \\
\text { at liberty (years) }\end{array}$ \\
\hline Male & 885 & 31 & 3.5 & 153.3 & 641 & 1.3 & 5.3 \\
\hline Female & 817 & 29 & 3.5 & 141.5 & 637 & 1.0 & 2.3 \\
\hline Unknown & 317 & 13 & 4.1 & 98.1 & 267 & 1.4 & 4.1 \\
\hline Total & 2,019 & 73 & 3.6 & 138.5 & 641 & 1.2 & 5.38 \\
\hline
\end{tabular}

\section{Yearly Summary of Tags, Recaptures, and Recapture Rate}

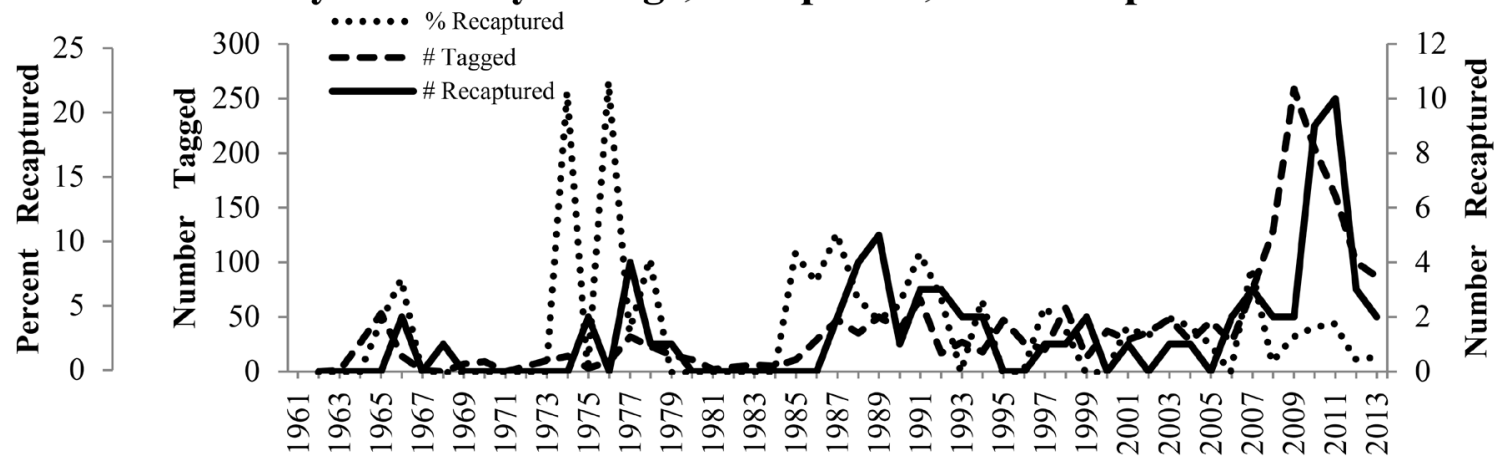

Year

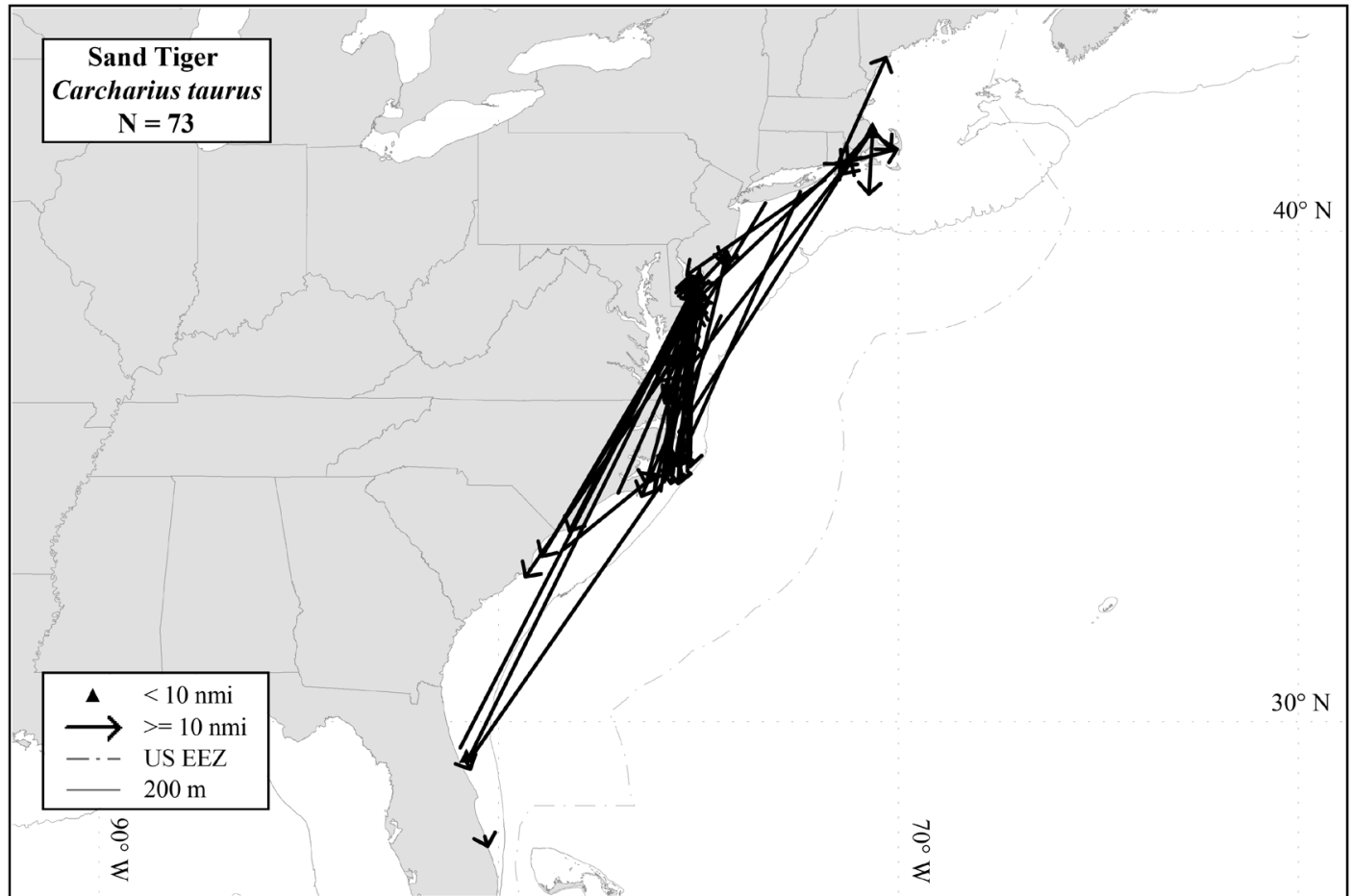

Figure 34a.-Distribution of recapture locations for the sand tiger, Carcharias taurus, from the NMFS Cooperative Shark Tagging Program (1962-2013). 


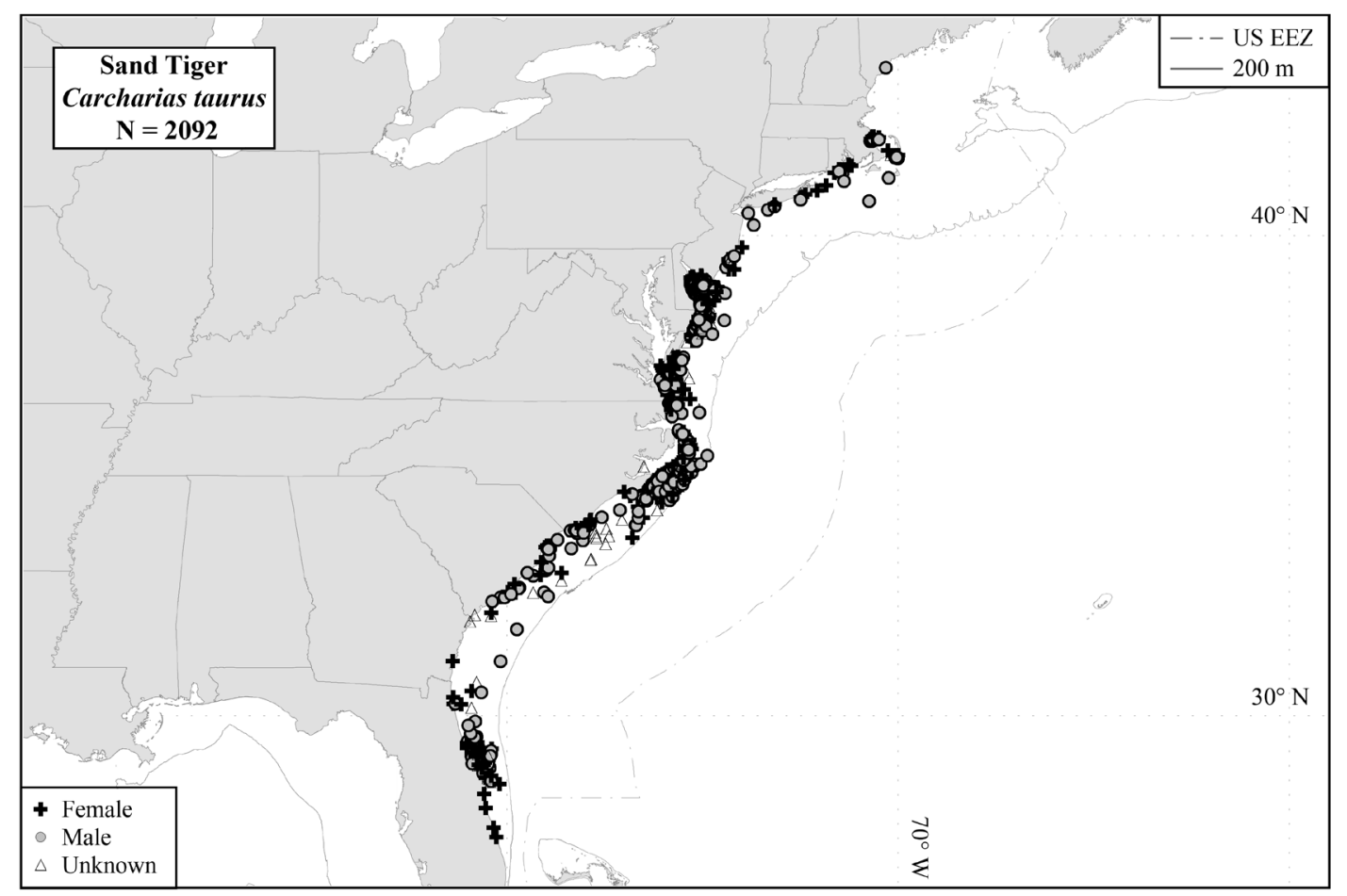

Figure 34b.-Distribution of mark/recapture locations for the sand tiger, Carcharias taurus, from the NMFS Cooperative Shark Tagging Program (1962-2013).
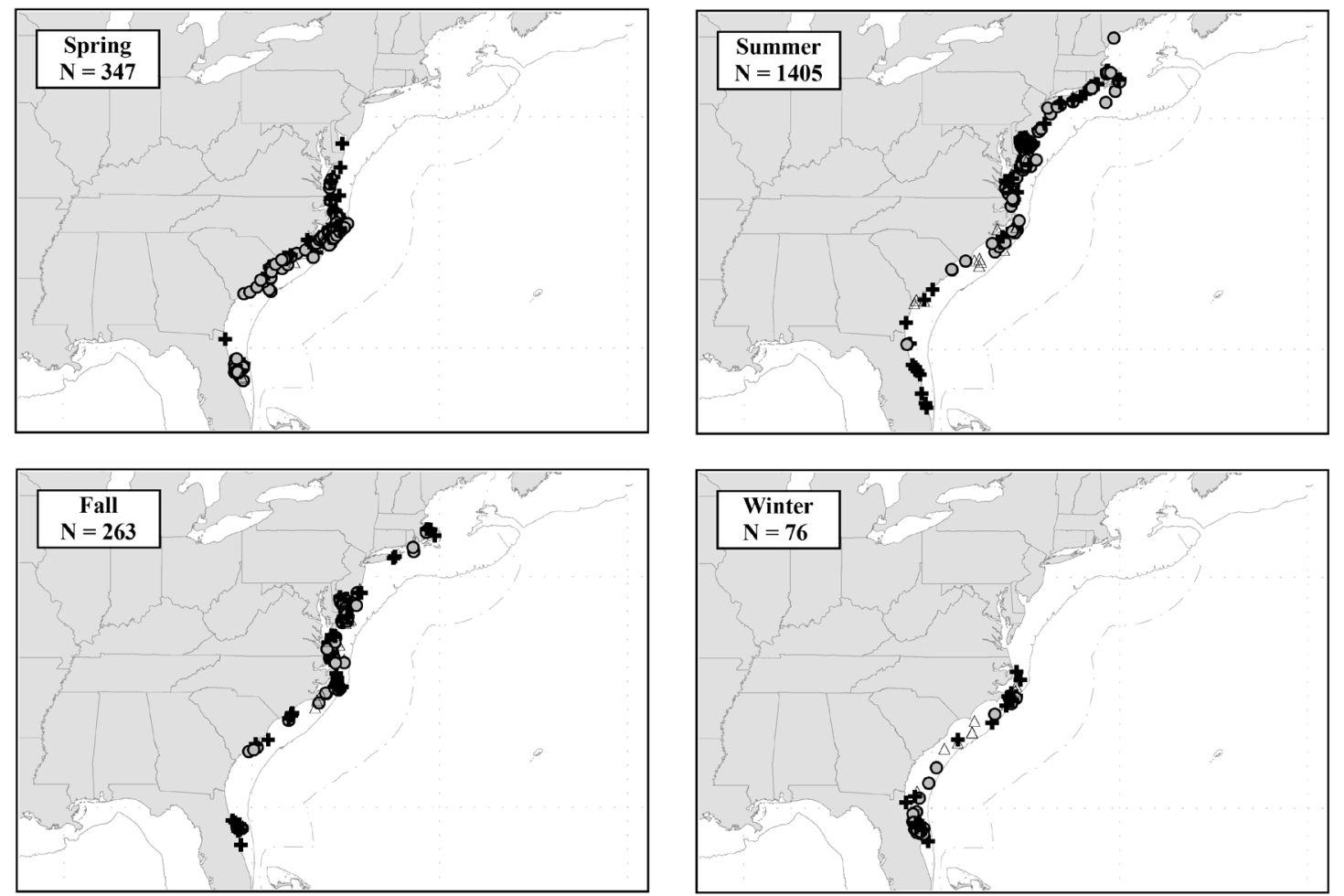

Figure 34c.- Seasonal distribution of mark/recapture locations for the sand tiger, Carcharias taurus, from the NMFS Cooperative Shark Tagging Program (1962-2013). 


\section{Scalloped Hammerhead}

\begin{tabular}{lcccccc}
\hline Sex & Tags & Recaptures & $\begin{array}{c}\text { Recapture rate } \\
(\%)\end{array}$ & $\begin{array}{c}\text { Mean distance } \\
\text { traveled (nmi) }\end{array}$ & $\begin{array}{c}\text { Maximum distance } \\
\text { traveled (nmi) }\end{array}$ & $\begin{array}{c}\text { Mean time at } \\
\text { liberty (years) }\end{array}$ \\
\hline Male & 1,612 & 33 & 2.0 & 161.1 & $\begin{array}{c}\text { Maximum time } \\
\text { at liberty (years) }\end{array}$ \\
Female & 1,504 & 19 & 1.3 & 117.5 & 765 & 2.7 \\
Unknown & 421 & 10 & 2.4 & 194.9 & 995 & 9.6 \\
Total & 3,537 & 62 & 1.8 & 152.5 & 902 & 3.7 \\
\hline
\end{tabular}

\section{Yearly Summary of Tags, Recaptures, and Recapture Rate}

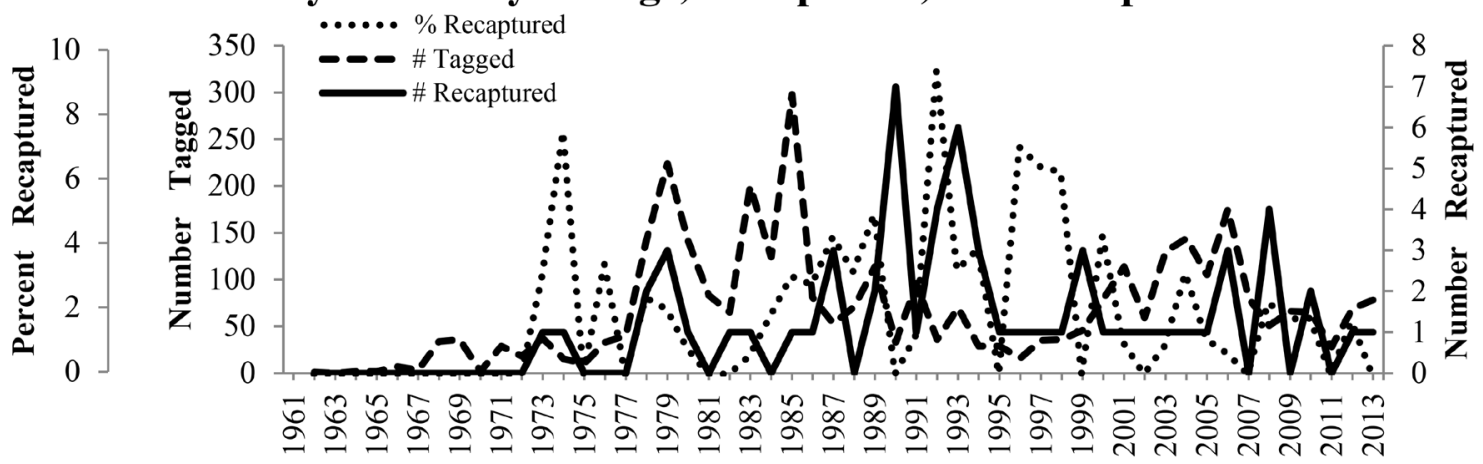

Year

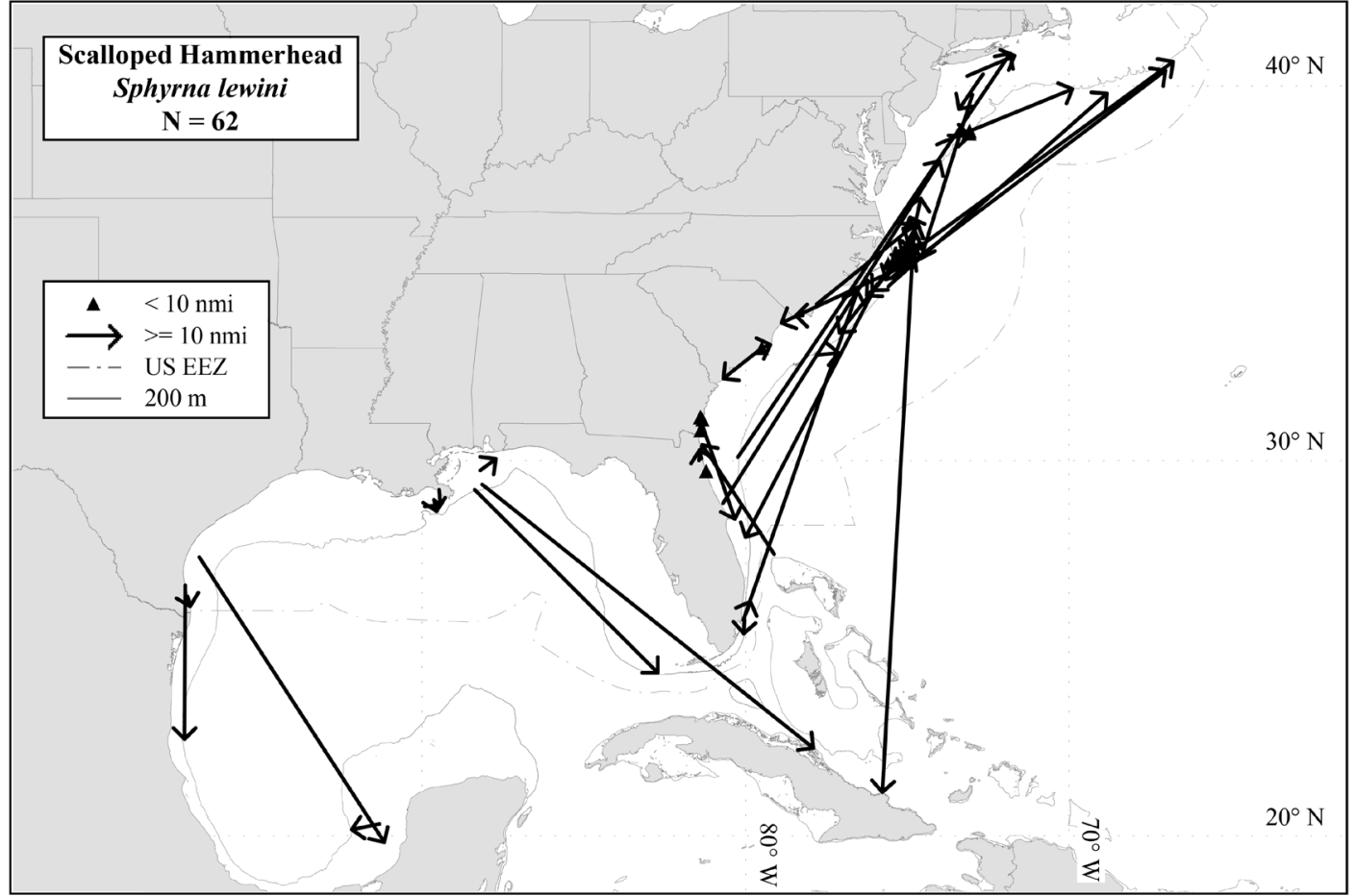

Figure 35a.-Distribution of recapture locations for the scalloped hammerhead, Sphyrna lewini, from the NMFS Cooperative Shark Tagging Program (1962-2013). 


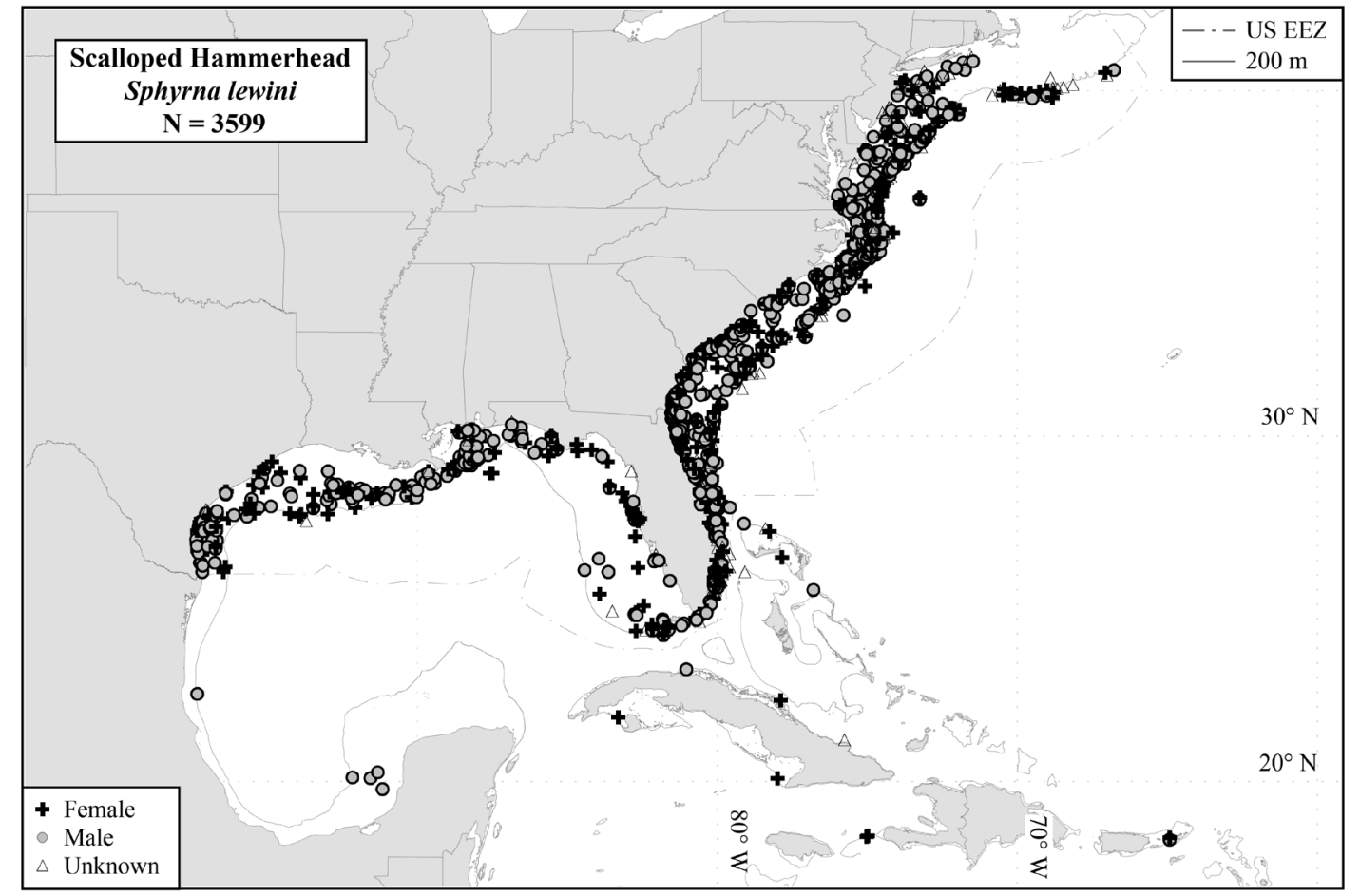

Figure 35b.-Distribution of mark/recapture locations for the scalloped hammerhead, Sphyrna lewini, from the NMFS Cooperative Shark Tagging Program (1962-2013).
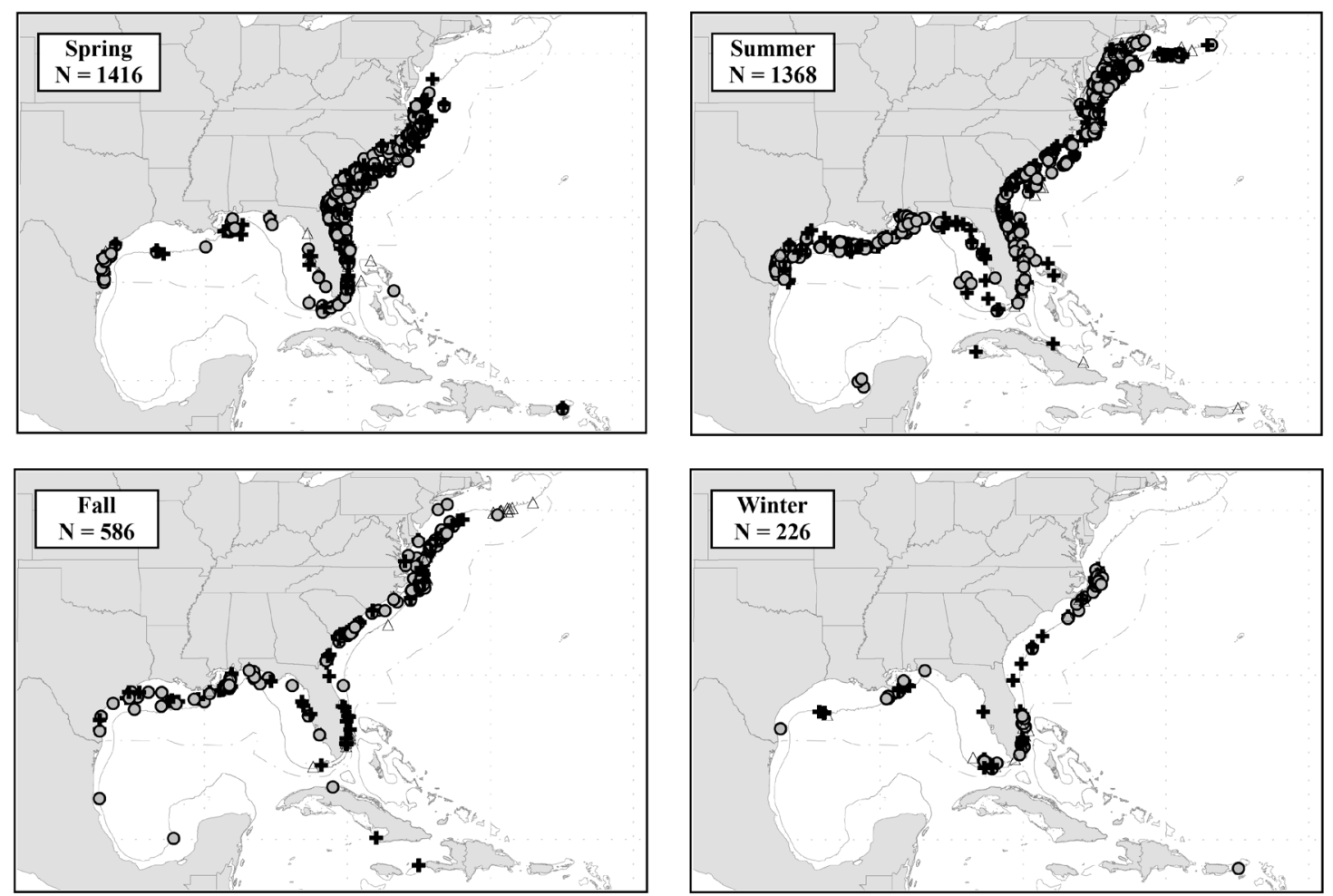

Figure 35c.- Seasonal distribution of mark/recapture locations for the scalloped hammerhead, Sphyrna lewini, from the NMFS Cooperative Shark Tagging Program (1962-2013). 


\section{Shortfin Mako}

\begin{tabular}{|c|c|c|c|c|c|c|c|}
\hline Sex & Tags & Recaptures & $\begin{array}{c}\text { Recapture rate } \\
(\%)\end{array}$ & $\begin{array}{l}\text { Mean distance } \\
\text { traveled (nmi) }\end{array}$ & $\begin{array}{l}\text { Maximum distance } \\
\text { traveled (nmi) }\end{array}$ & $\begin{array}{l}\text { Mean time at } \\
\text { liberty (years) }\end{array}$ & $\begin{array}{l}\text { Maximum time } \\
\text { at liberty (years) }\end{array}$ \\
\hline Male & 1,917 & 373 & 19.5 & 512.8 & 2,867 & 1.3 & 12.8 \\
\hline Female & 3,251 & 491 & 15.1 & 421.4 & 2,306 & 1.1 & 12.4 \\
\hline Unknown & 3,357 & 284 & 8.5 & 494.7 & 3,043 & 1.2 & 9.5 \\
\hline Total & 8,525 & 1148 & 13.5 & 469.1 & 3,043 & 1.2 & 12.8 \\
\hline
\end{tabular}

\section{Yearly Summary of Tags, Recaptures, and Recapture Rate}

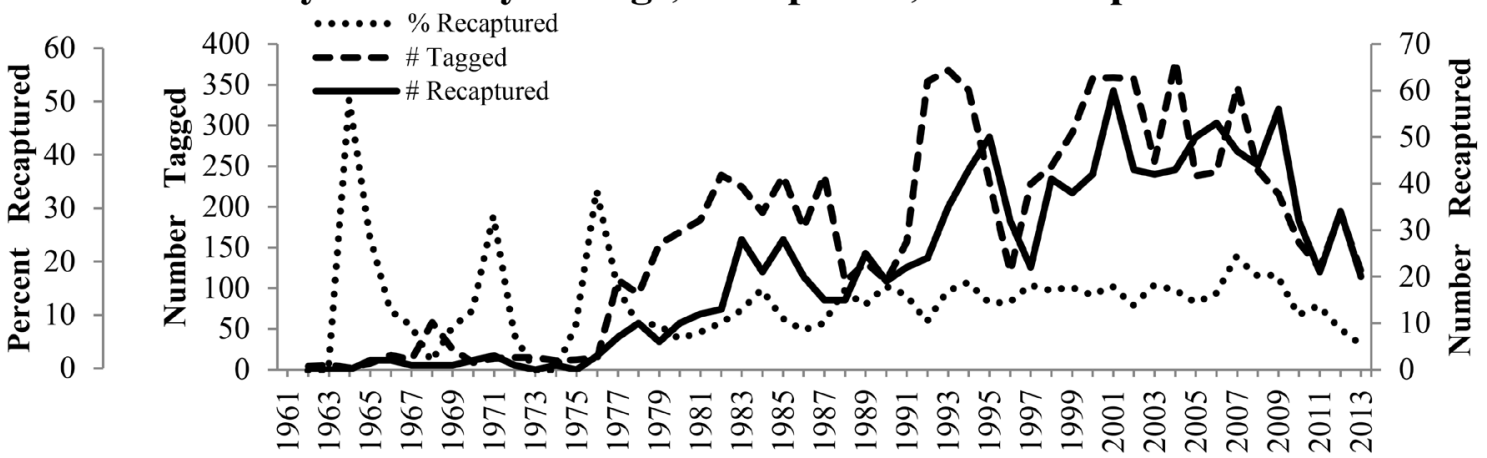

Year

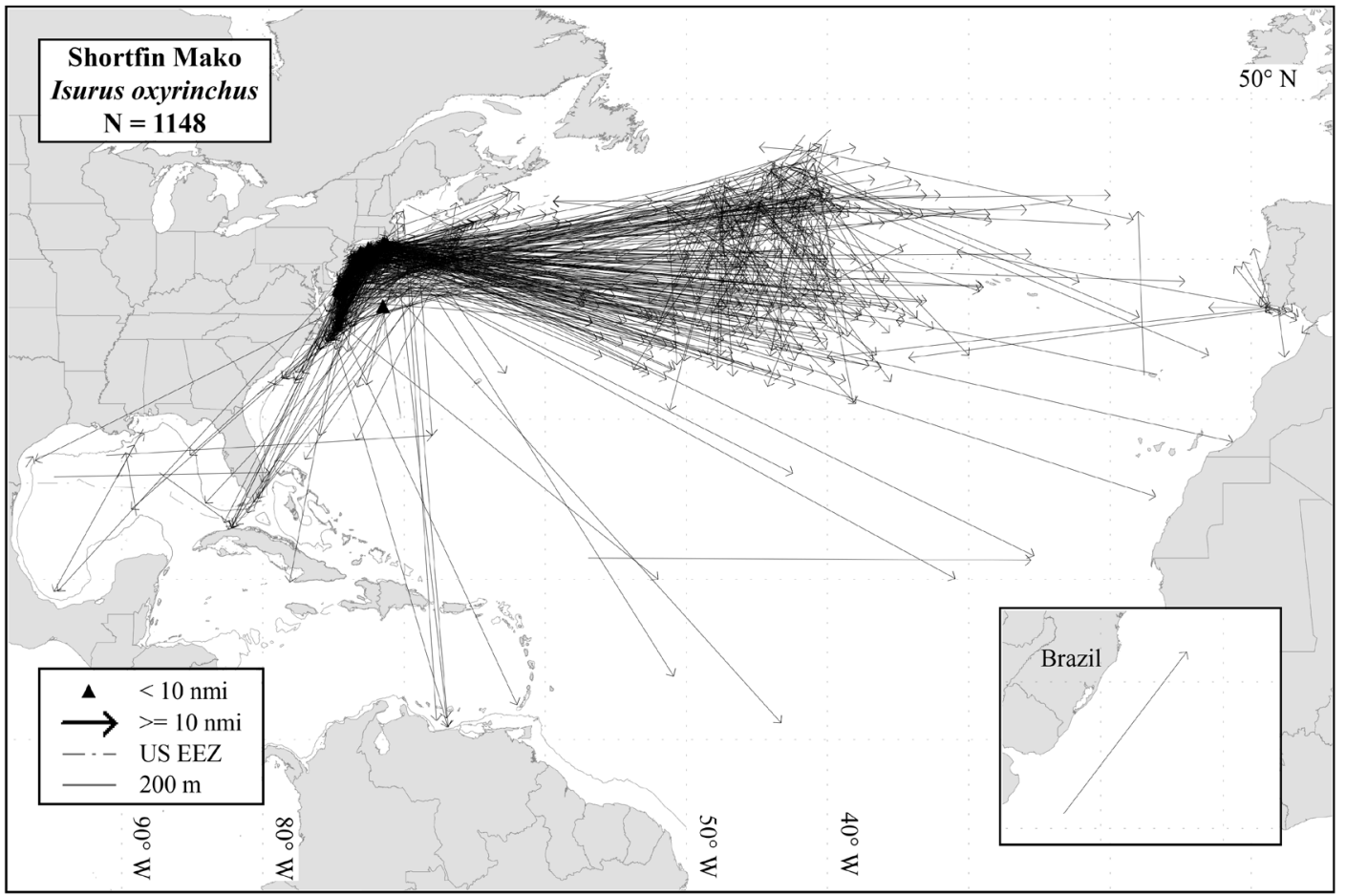

Figure 36a.-Distribution of recapture locations for the shortfin mako, Isurus oxyrinchus, from the NMFS Cooperative Shark Tagging Program (1962-2013). 


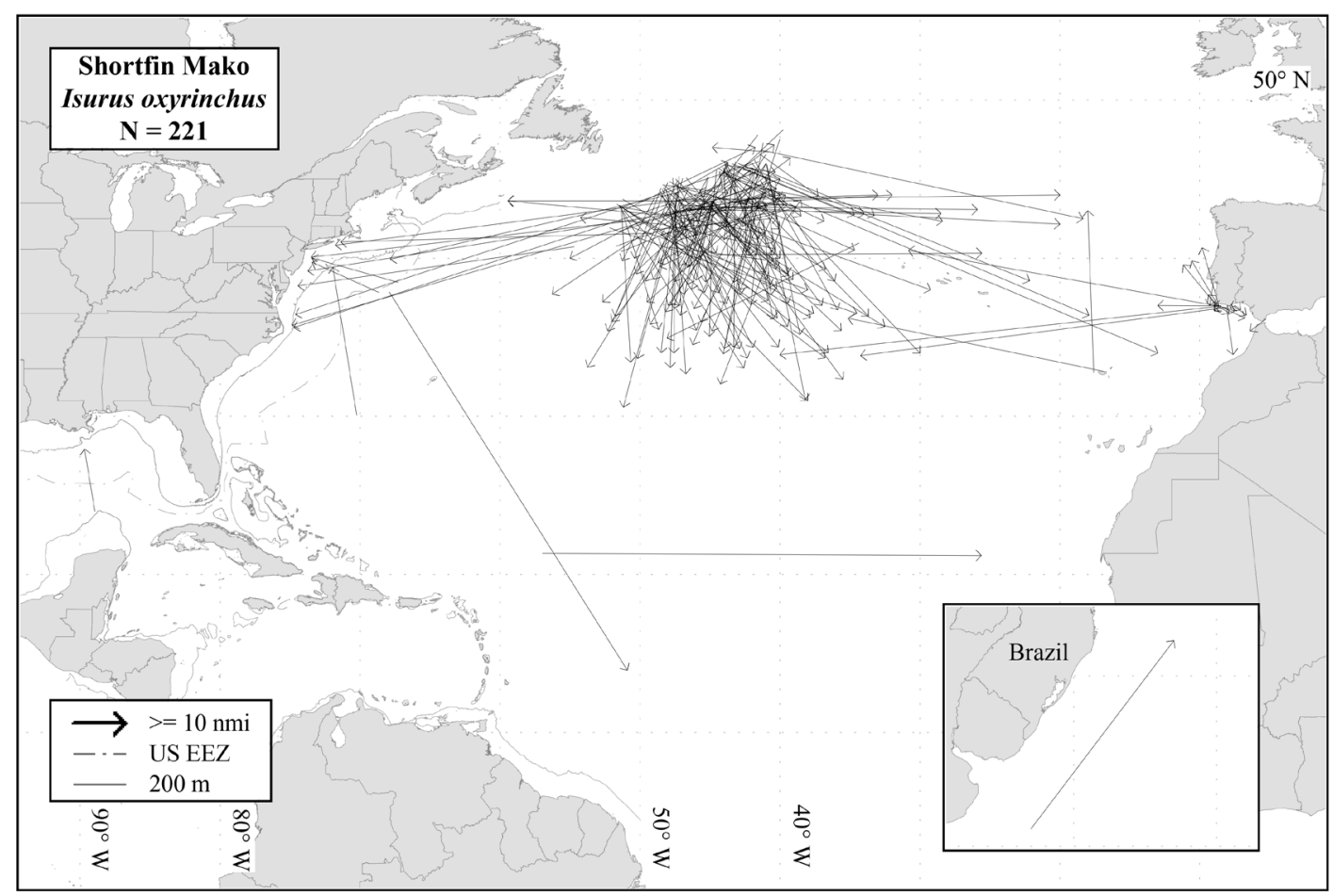

Figure 36b.-Distribution of recapture locations for the shortfin mako, Isurus oxyrinchus, tagged outside the U.S. EEZ from the NMFS Cooperative Shark Tagging Program (1962-2013).

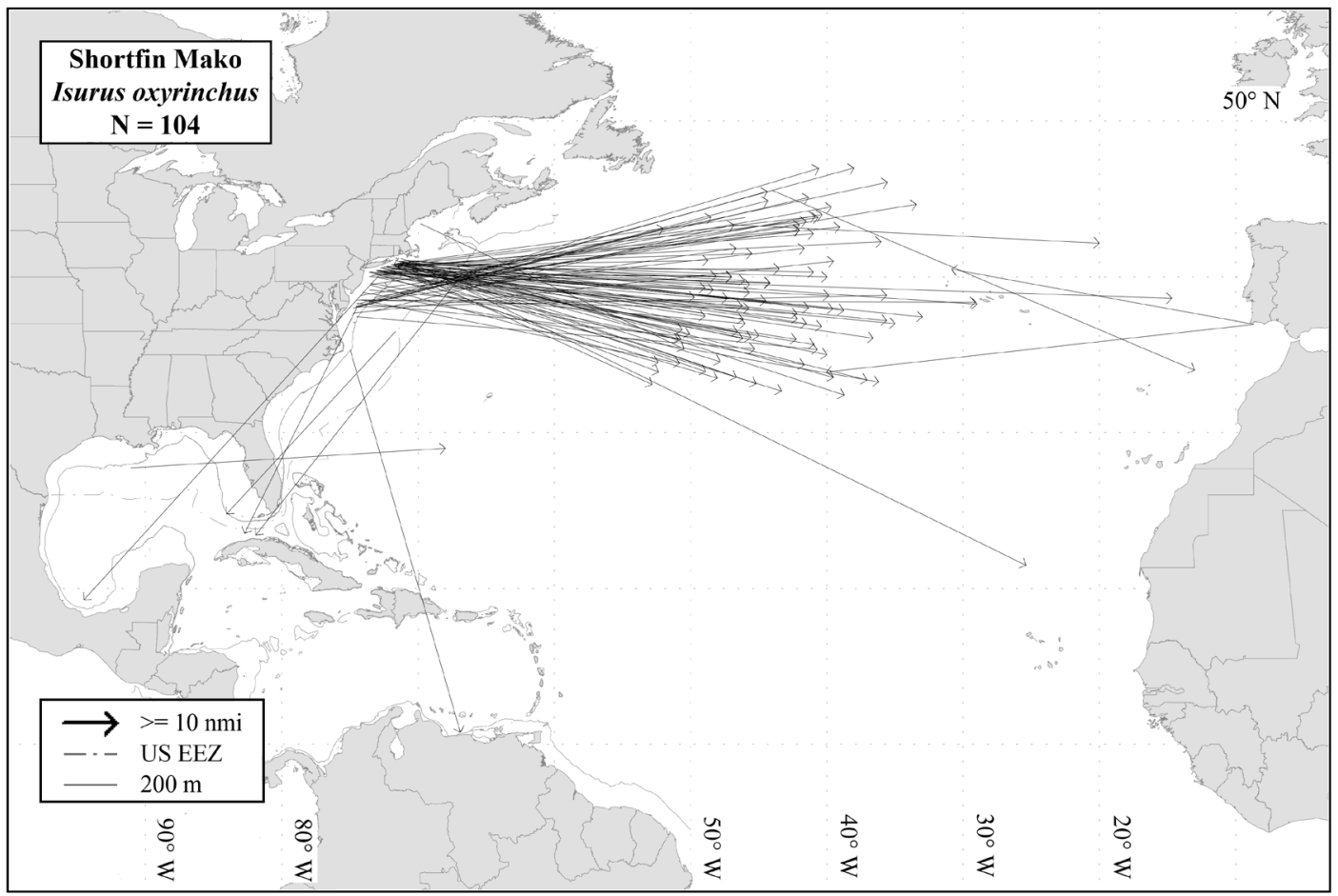

Figure 36c.- - Long distance recaptures (> $1000 \mathrm{nmi}$ ) for the shortfin mako, Isurus oxyrinchus, at liberty for less than one year from the NMFS Cooperative Shark Tagging Program (1962-2013). 


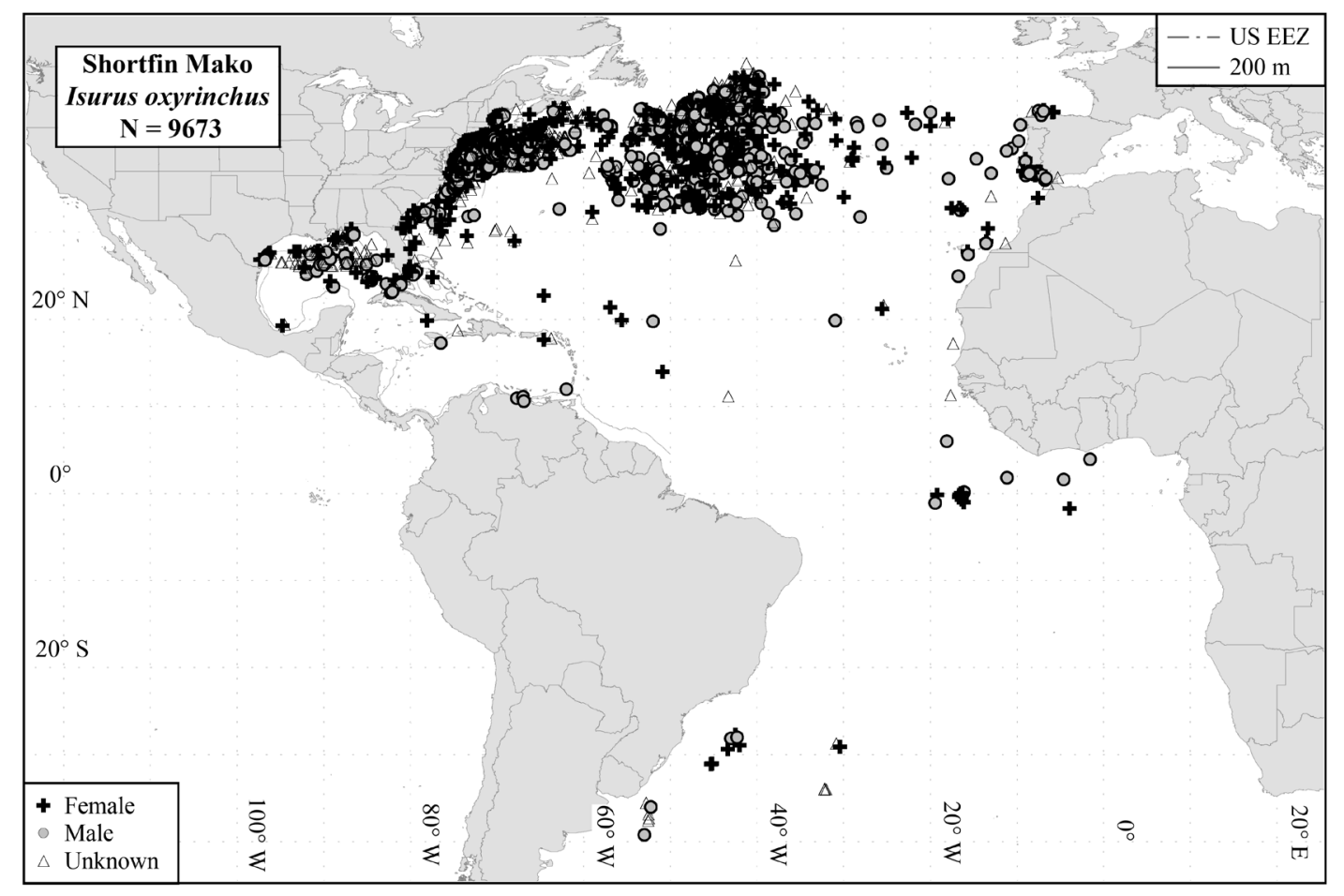

Figure 36d.-Distribution of mark/recapture locations for the shortfin mako, Isurus oxyrinchus, from the NMFS Cooperative Shark Tagging Program (1962-2013).
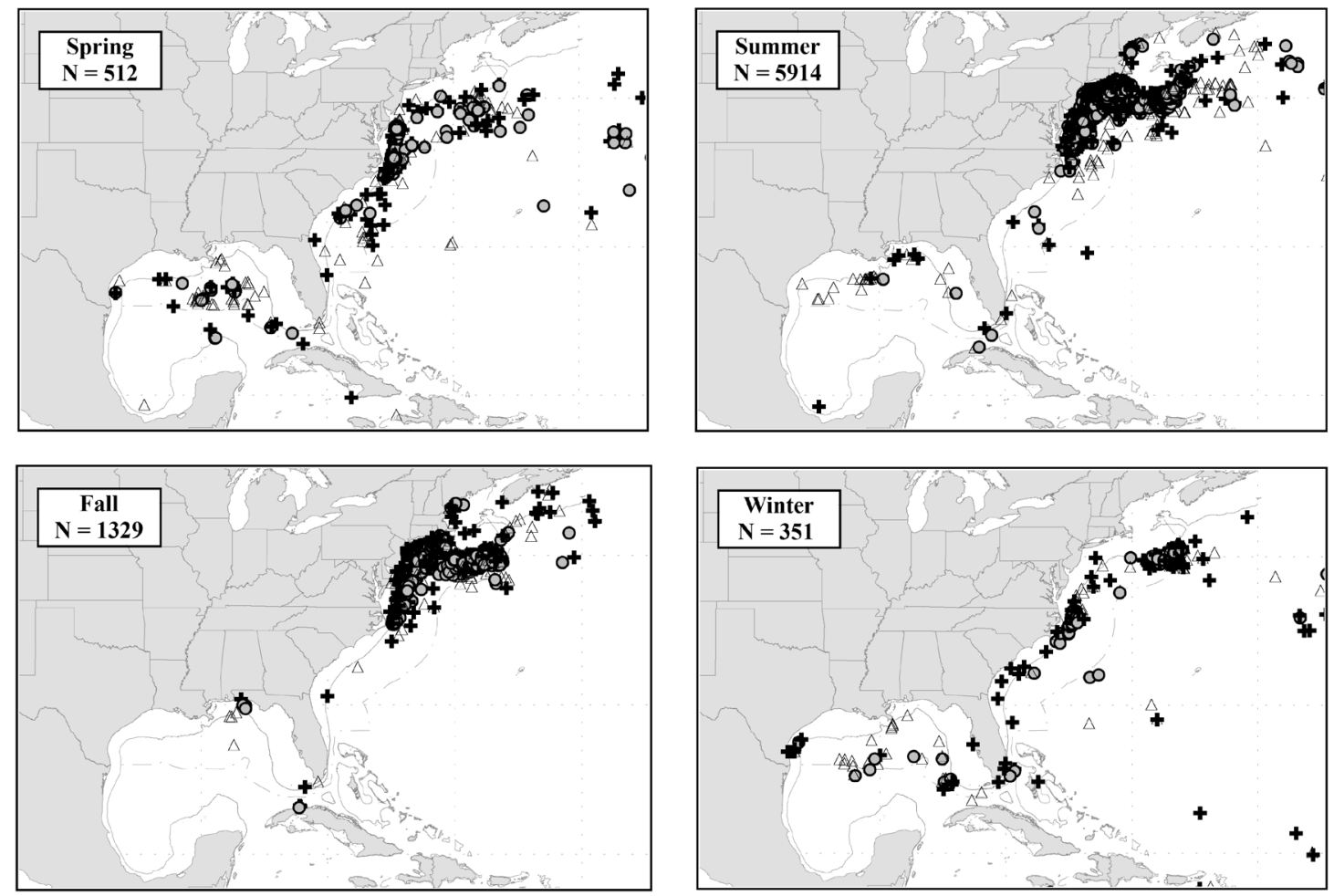

Figure 36e.- Seasonal distribution of mark/recapture locations in the western North Atlantic for the shortfin mako, Isurus oxyrinchus, from the NMFS Cooperative Shark Tagging Program (1962-2013). 


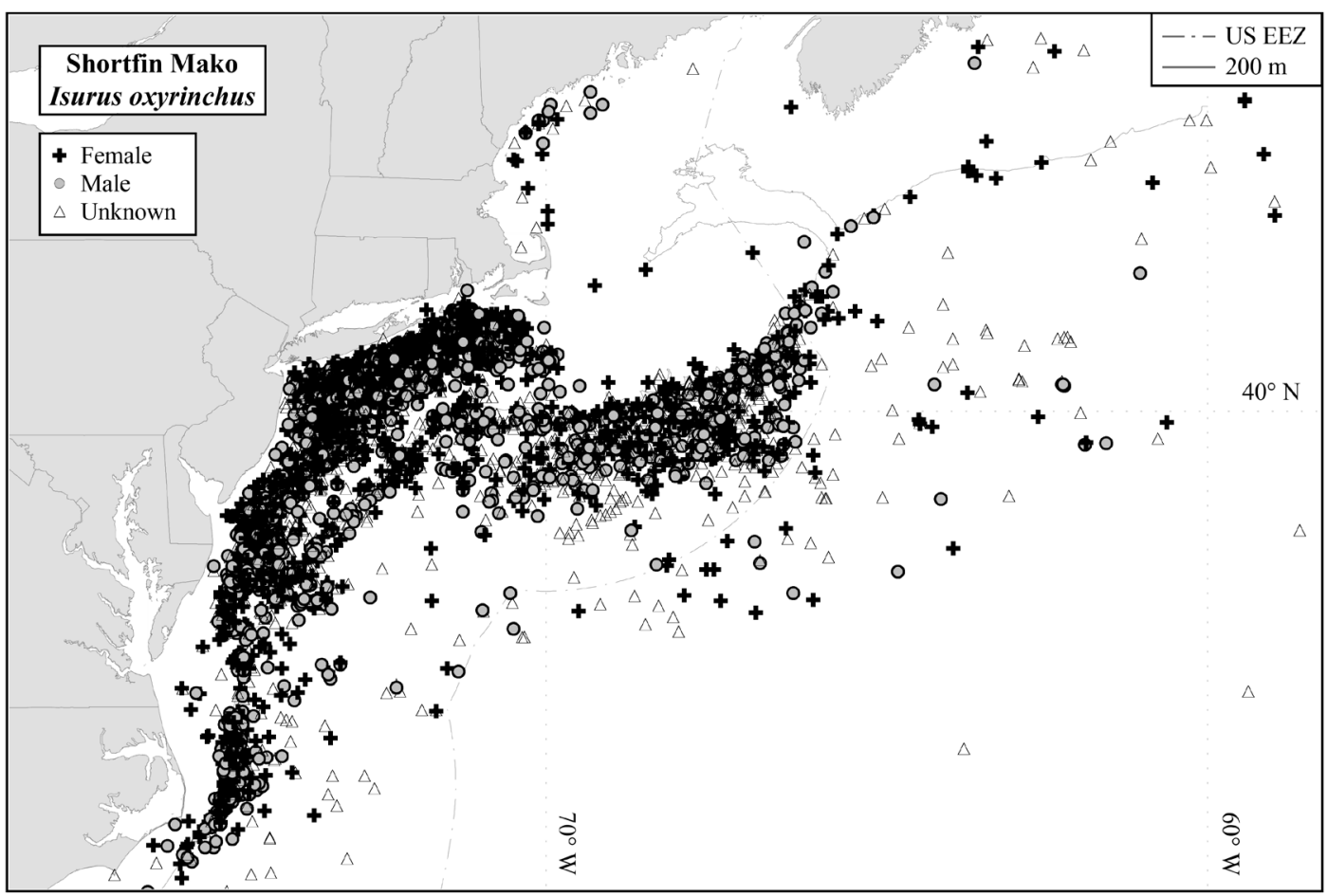

Figure 36f.-Distribution of mark/recapture locations in the northeastern U.S. for the shortfin mako, Isurus oxyrinchus, from the NMFS Cooperative Shark Tagging Program (1962-2013).

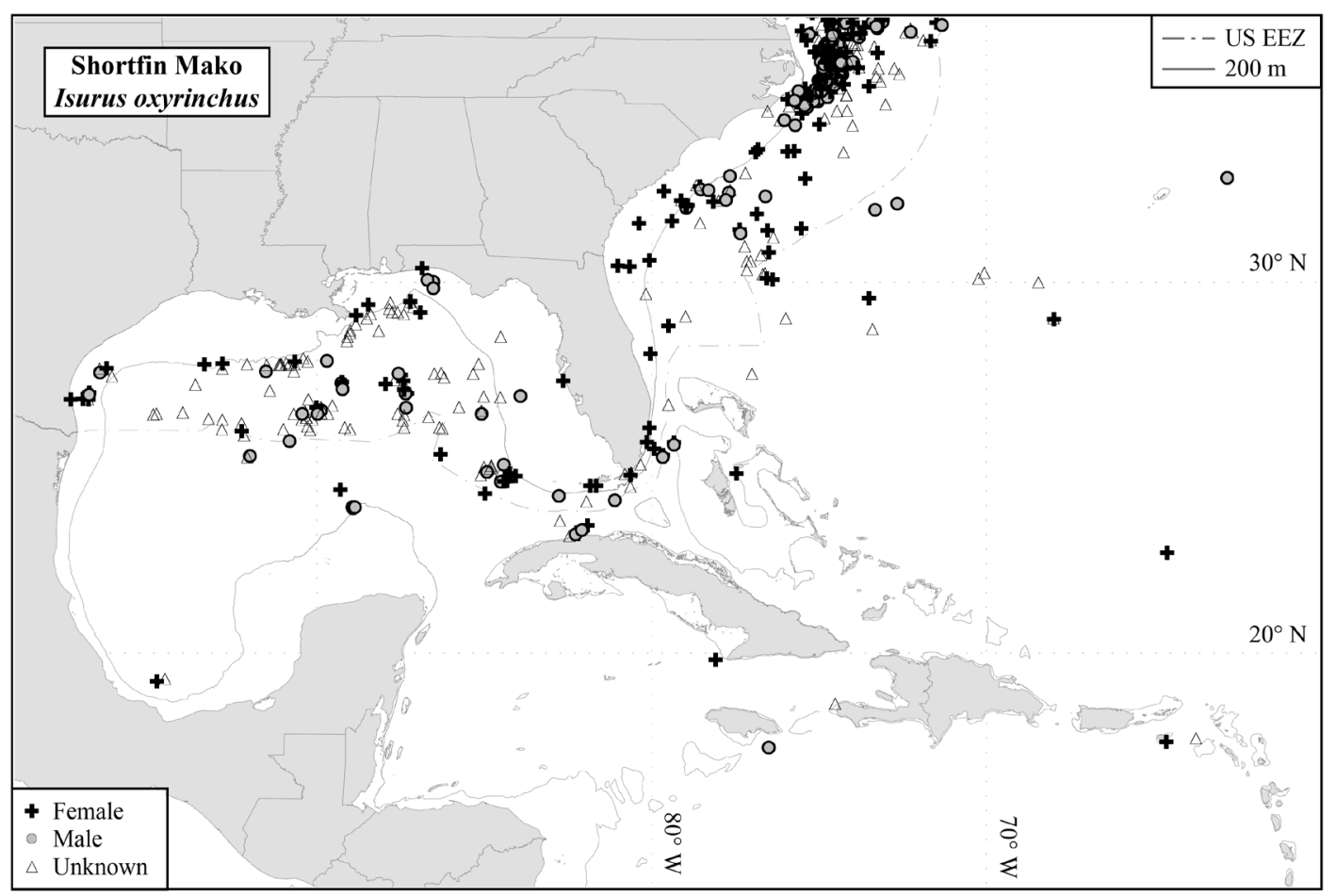

Figure 36g.-Distribution of mark/recapture locations in the southeastern U.S. for the shortfin mako, Isurus oxyrinchus, from the NMFS Cooperative Shark Tagging Program (1962-2013). 


\section{Silky Shark}

\begin{tabular}{lccccrr}
\hline Sex & Tags & Recaptures & $\begin{array}{c}\text { Recapture rate } \\
(\%)\end{array}$ & $\begin{array}{c}\text { Mean distance } \\
\text { traveled (nmi) }\end{array}$ & $\begin{array}{c}\text { Maximum distance } \\
\text { traveled (nmi) }\end{array}$ & $\begin{array}{c}\text { Mean time at } \\
\text { liberty (years) }\end{array}$ \\
\hline Male & 340 & 23 & 6.8 & 204.0 & $\begin{array}{c}\text { Maximum time } \\
\text { at liberty (years) }\end{array}$ \\
Female & 464 & 21 & 4.5 & 255.6 & 718 & 1.1 \\
Unknown & 434 & 21 & 4.8 & 132.4 & 6.0 & 0.9 \\
Total & 1,238 & 65 & 5.3 & 197.6 & 539 & 0.7 \\
\hline
\end{tabular}

Yearly Summary of Tags, Recaptures, and Recapture Rate
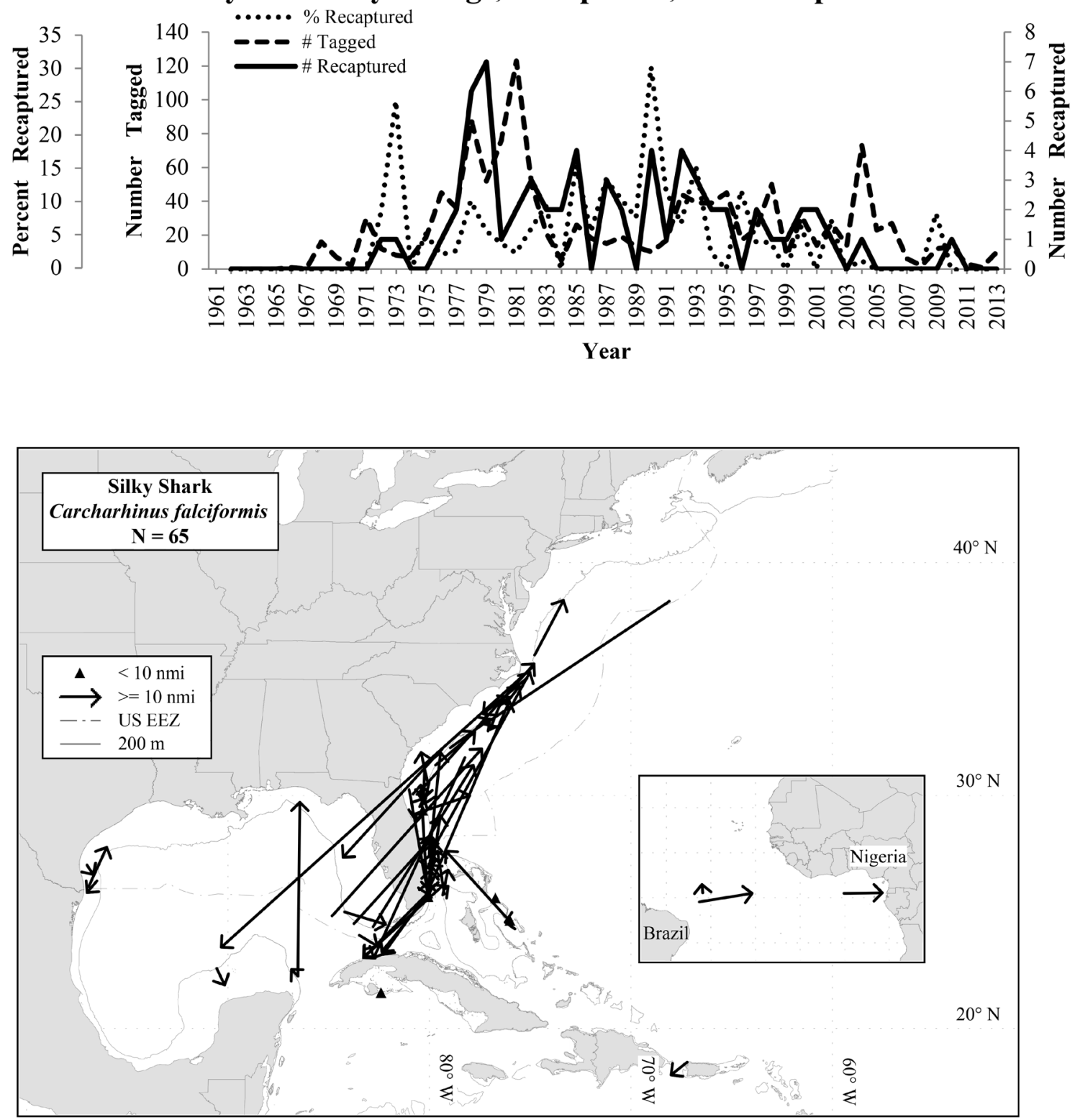

Figure 37a.-Distribution of recapture locations for the silky shark, Carcharhinus falciformis, from the NMFS Cooperative Shark Tagging Program (1962-2013). 


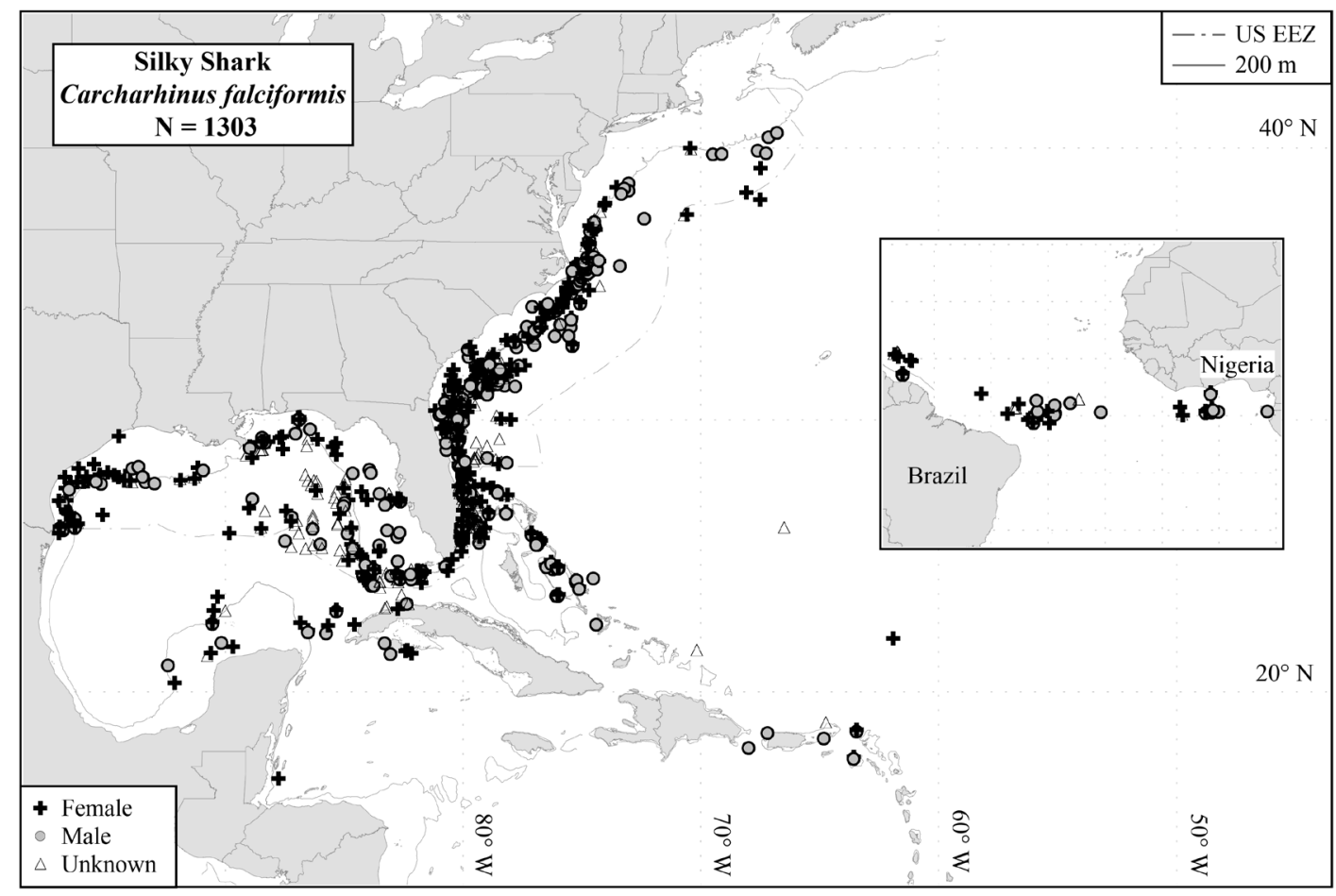

Figure 37b.-Distribution of mark/recapture locations for the silky shark, Carcharhinus falciformis, from the NMFS Cooperative Shark Tagging Program (1962-2013).
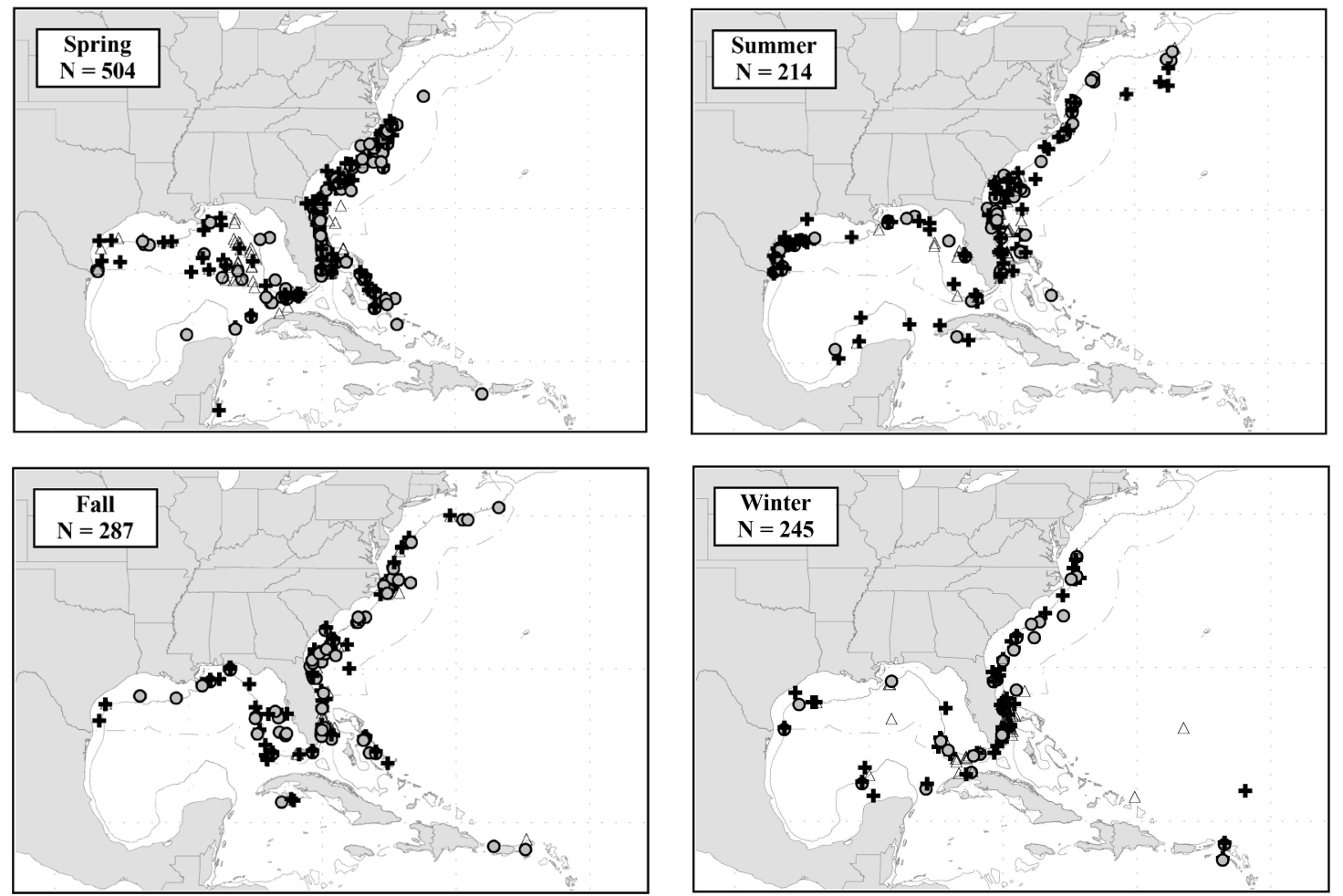

Figure 37c.- Seasonal distribution of mark/recapture locations in the western North Atlantic for silky shark, Carcharhinus falciformis, from the NMFS Cooperative Shark Tagging Program (1962-2013). 


\section{Smalltail Shark}

\begin{tabular}{|c|c|c|c|c|c|c|c|}
\hline Sex & Tags & Recaptures & $\begin{array}{c}\text { Recapture rate } \\
(\%)\end{array}$ & $\begin{array}{l}\text { Mean distance } \\
\text { traveled (nmi) }\end{array}$ & $\begin{array}{l}\text { Maximum distance } \\
\text { traveled (nmi) }\end{array}$ & $\begin{array}{l}\text { Mean time at } \\
\text { liberty (years) }\end{array}$ & $\begin{array}{l}\text { Maximum time } \\
\text { at liberty (years) }\end{array}$ \\
\hline Male & 8 & 0 & 0.0 & & & & \\
\hline Female & 14 & 0 & 0.0 & & & & \\
\hline Unknown & 2 & 0 & 0.0 & & & & \\
\hline Total & 24 & 0 & 0.0 & & & & \\
\hline
\end{tabular}

\section{Yearly Summary of Tags}
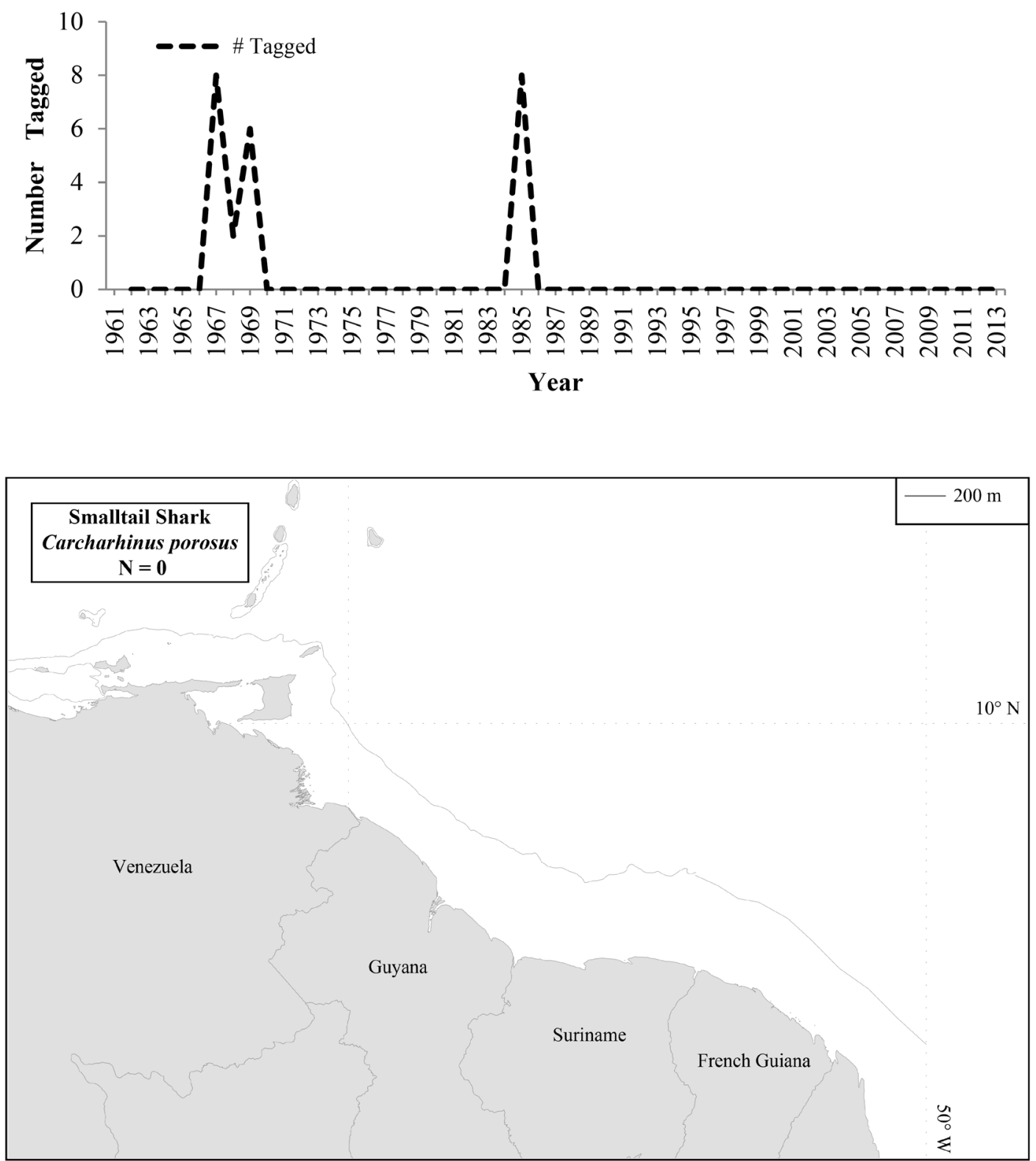

Figure 38a.-Distribution of recapture locations for the smalltail shark, Carcharhinus porosus, from the NMFS Cooperative Shark Tagging Program (1962-2013). 


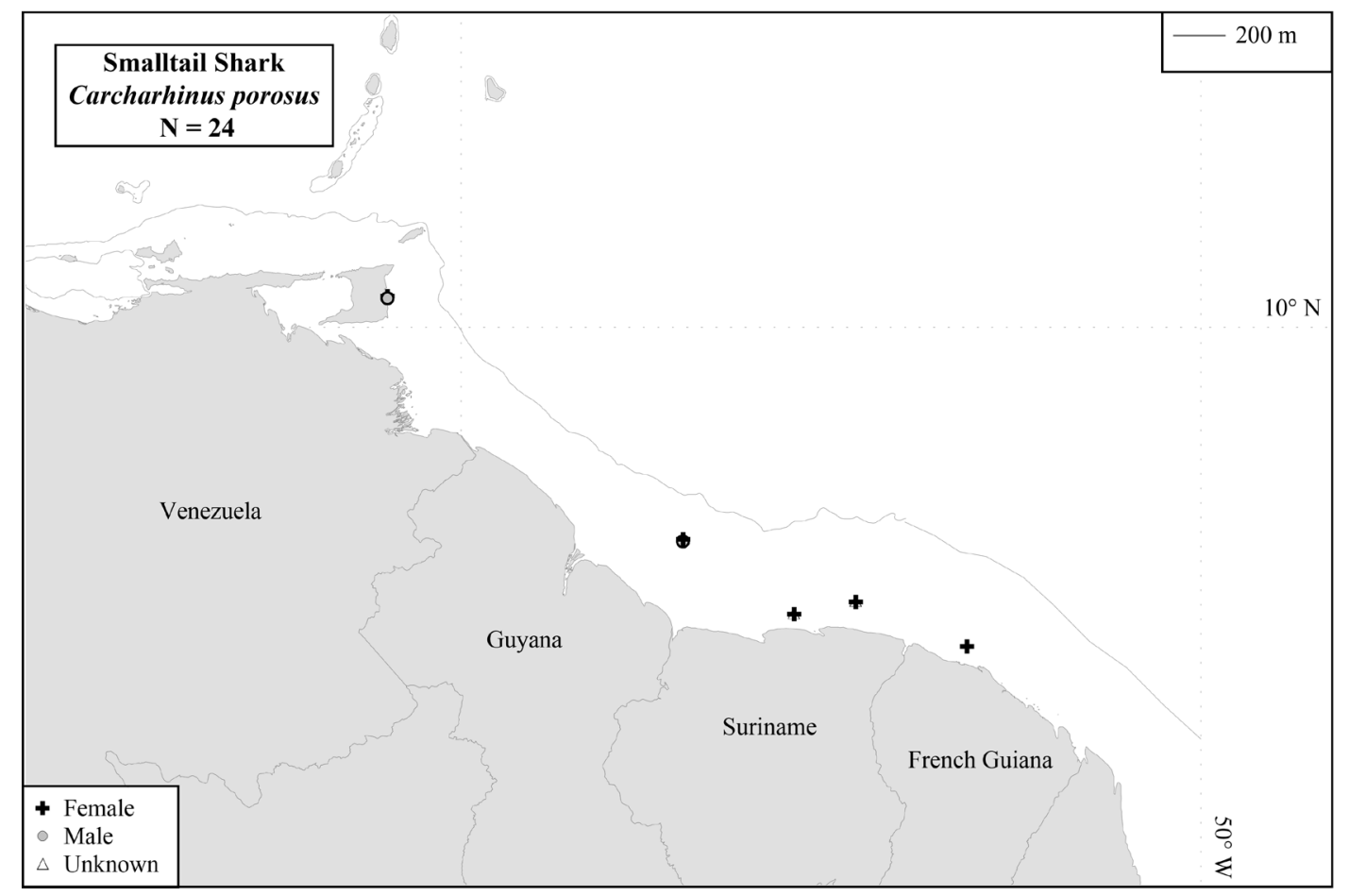

Figure 38b.-Distribution of mark/recapture locations for the smalltail shark, Carcharhinus porosus, from the NMFS Cooperative Shark Tagging Program (1962-2013).
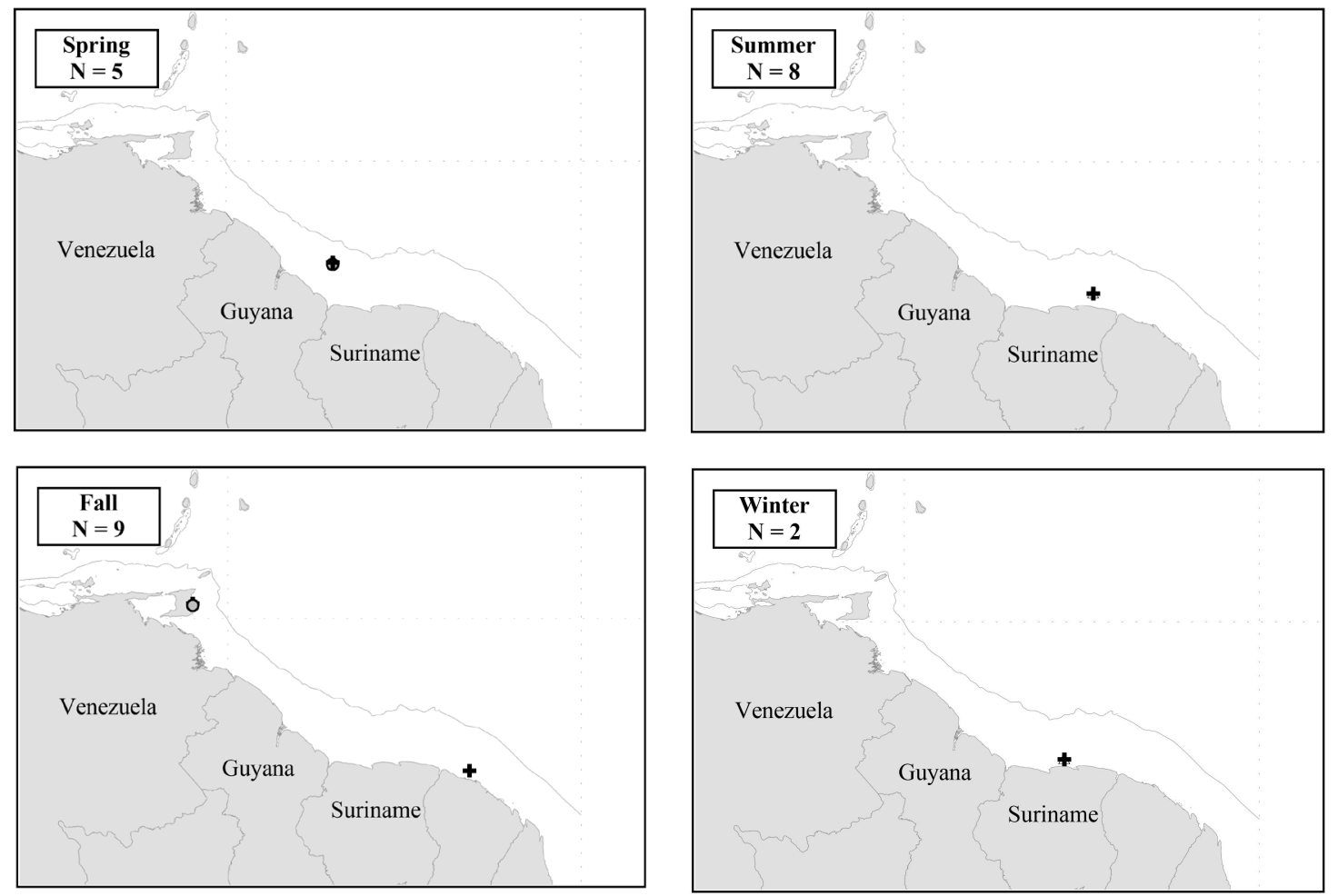

Figure 38c.- Seasonal distribution of mark/recapture locations for the smalltail shark, Carcharhinus porosus, from the NMFS Cooperative Shark Tagging Program (1962-2013). 


\section{Smooth Dogfish}

\begin{tabular}{|c|c|c|c|c|c|c|c|}
\hline Sex & Tags & Recaptures & $\begin{array}{c}\text { Recapture rate } \\
(\%)\end{array}$ & $\begin{array}{l}\text { Mean distance } \\
\text { traveled (nmi) }\end{array}$ & $\begin{array}{l}\text { Maximum distance } \\
\text { traveled (nmi) }\end{array}$ & $\begin{array}{l}\text { Mean time at } \\
\text { liberty (years) }\end{array}$ & $\begin{array}{l}\text { Maximum time } \\
\text { at liberty (years) }\end{array}$ \\
\hline Male & 263 & 5 & 1.9 & 147.8 & 379 & 2.1 & 4.1 \\
\hline Female & 842 & 29 & 3.4 & 114.2 & 460 & 2.0 & 6.8 \\
\hline Unknown & 81 & 3 & 3.7 & 140.7 & 152 & 0.4 & 0.8 \\
\hline Total & 1,186 & 37 & 3.1 & 120.9 & 460 & 1.9 & 6.8 \\
\hline
\end{tabular}

Yearly Summary of Tags, Recaptures, and Recapture Rate
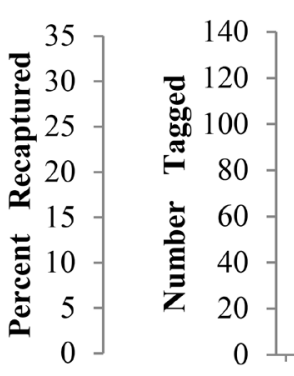

.....\% \% Recaptured

- - \# Tagged

\# Recaptured

(1)

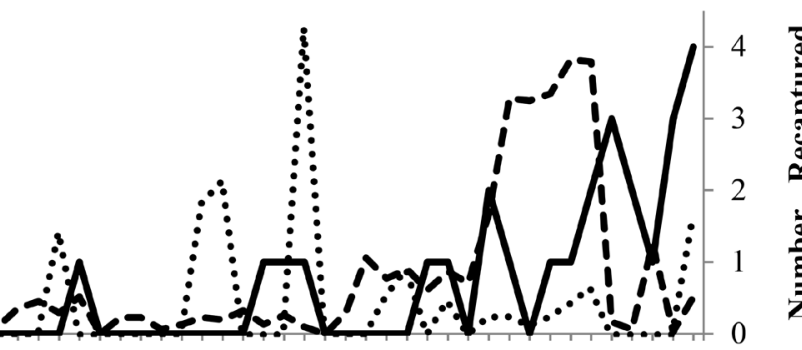

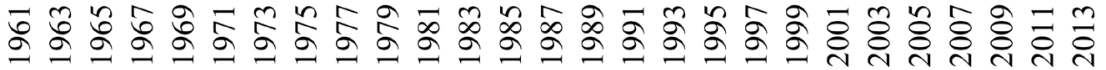

\section{Year}

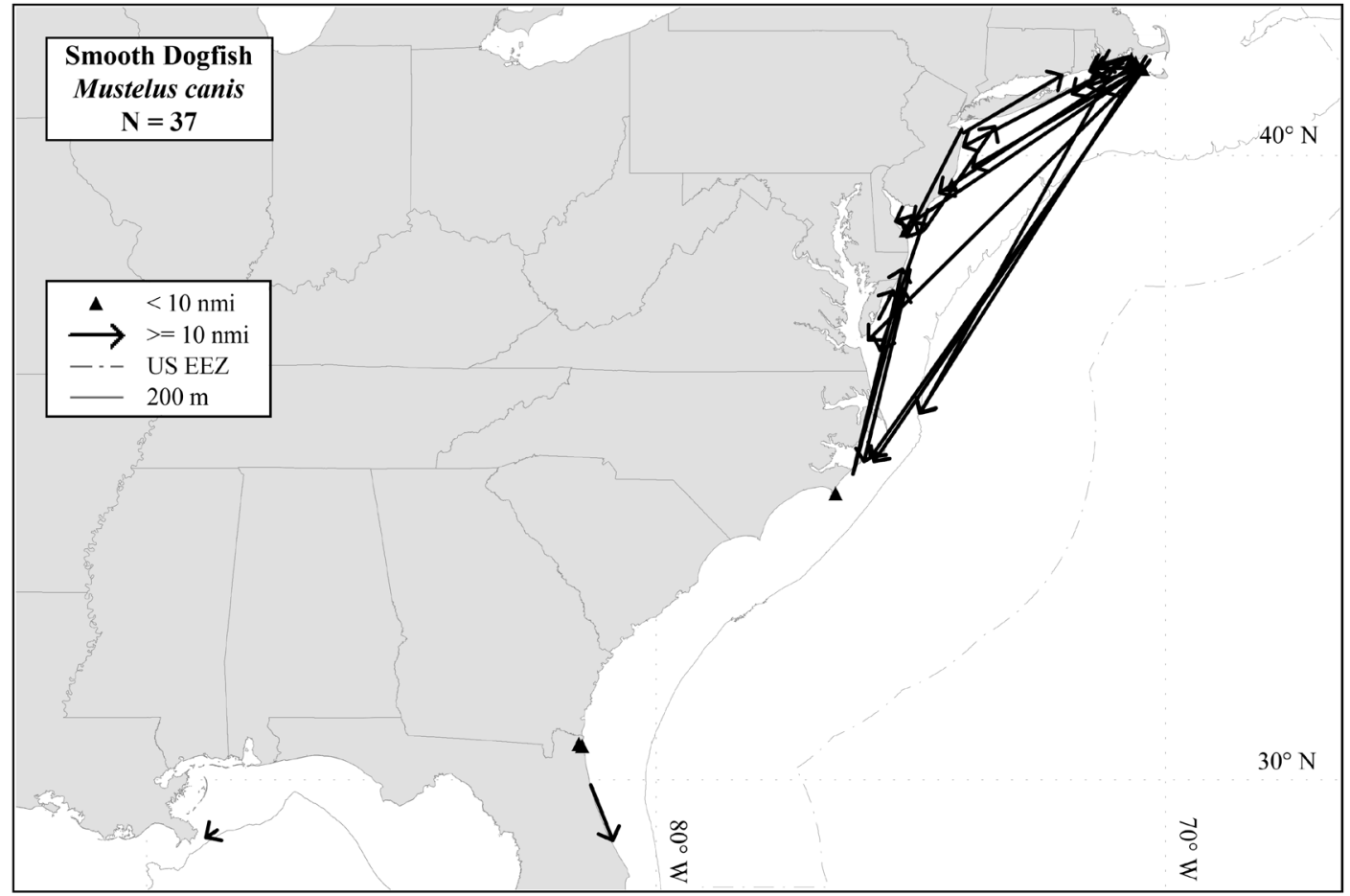

Figure 39a.-Distribution of recapture locations for the smooth dogfish, Mustelus canis, from the NMFS Cooperative Shark Tagging Program (1962-2013). 


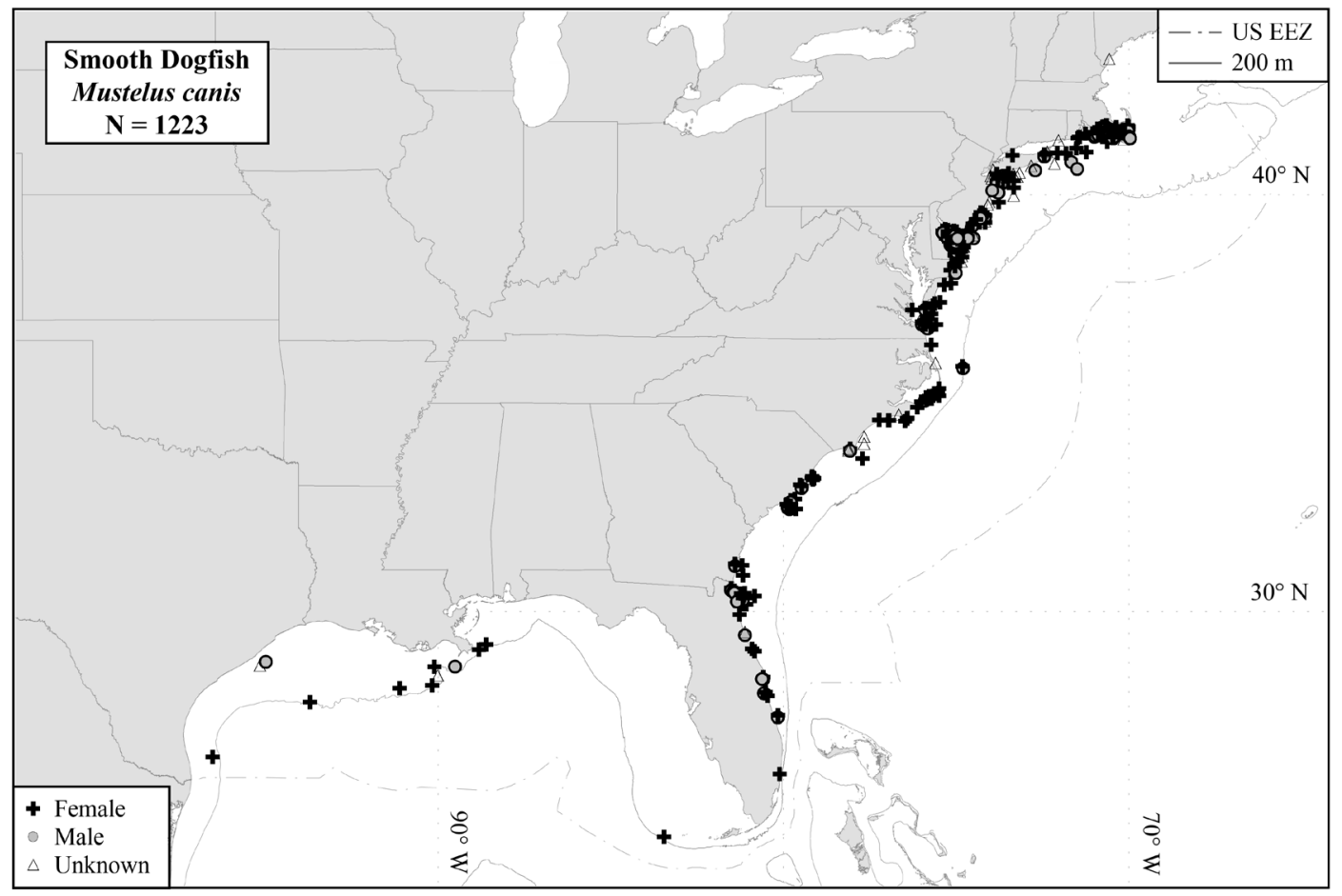

Figure 39b.-Distribution of mark/recapture locations for the smooth dogfish, Mustelus canis, from the NMFS Cooperative Shark Tagging Program (1962-2013).
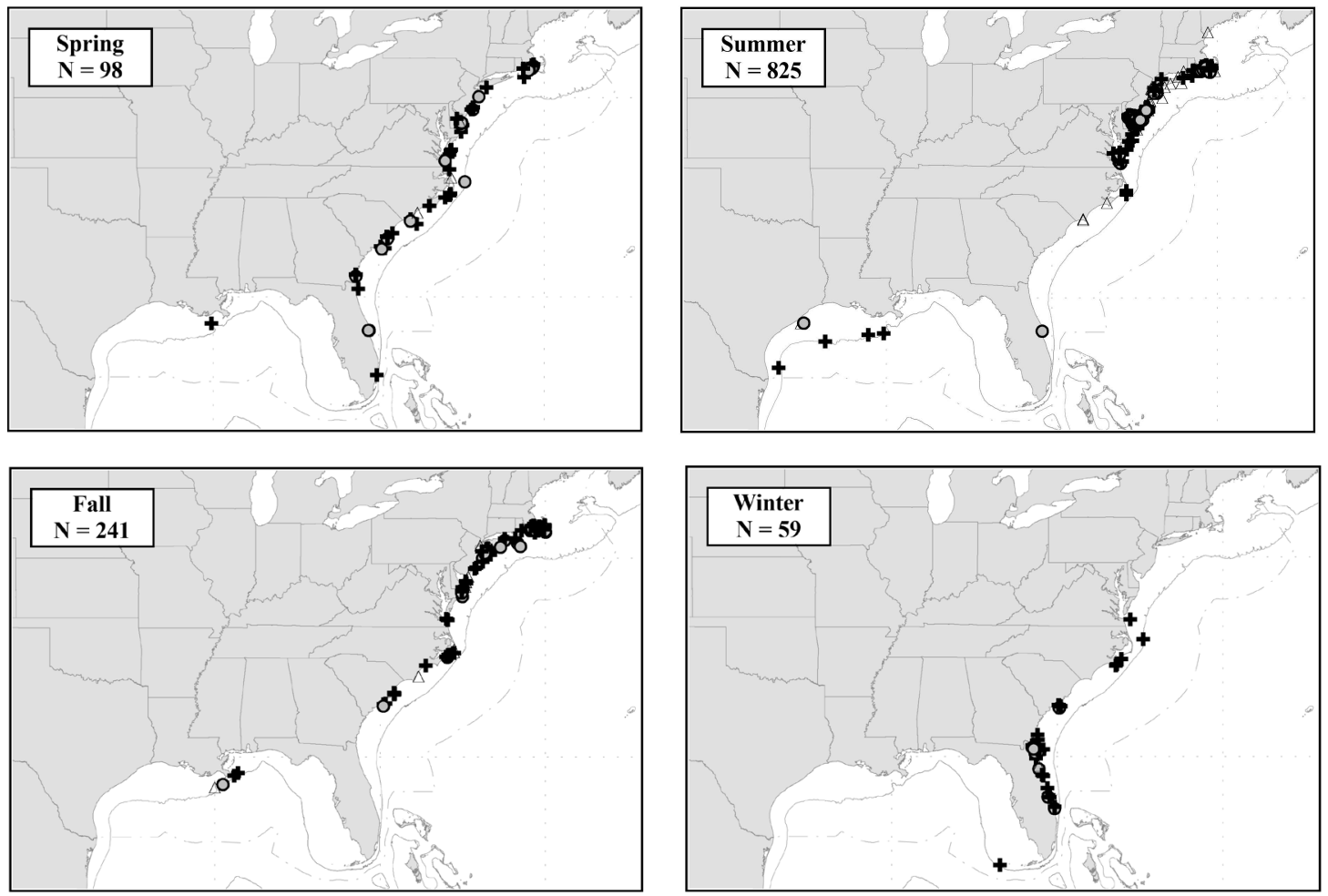

Figure 39c.- Seasonal distribution of mark/recapture locations for the smooth dogfish, Mustelus canis, from the NMFS Cooperative Shark Tagging Program (1962-2013). 


\section{Smooth Hammerhead}

\begin{tabular}{|c|c|c|c|c|c|c|c|}
\hline Sex & Tags & Recaptures & $\begin{array}{c}\text { Recapture rate } \\
(\%)\end{array}$ & $\begin{array}{l}\text { Mean distance } \\
\text { traveled (nmi) }\end{array}$ & $\begin{array}{l}\text { Maximum distance } \\
\text { traveled (nmi) }\end{array}$ & $\begin{array}{l}\text { Mean time at } \\
\text { liberty (years) }\end{array}$ & $\begin{array}{l}\text { Maximum time } \\
\text { at liberty (years) }\end{array}$ \\
\hline Male & 112 & 2 & 1.8 & 289.0 & 496 & 1.3 & 2.1 \\
\hline Female & 121 & 3 & 2.5 & 61.3 & 178 & 0.8 & 1.3 \\
\hline Unknown & 36 & 2 & 5.6 & 119.5 & 184 & 0.9 & 1.7 \\
\hline Total & 269 & 7 & 2.6 & 143.0 & 496 & 1.0 & 2.1 \\
\hline
\end{tabular}

\section{Yearly Summary of Tags, Recaptures, and Recapture Rate}
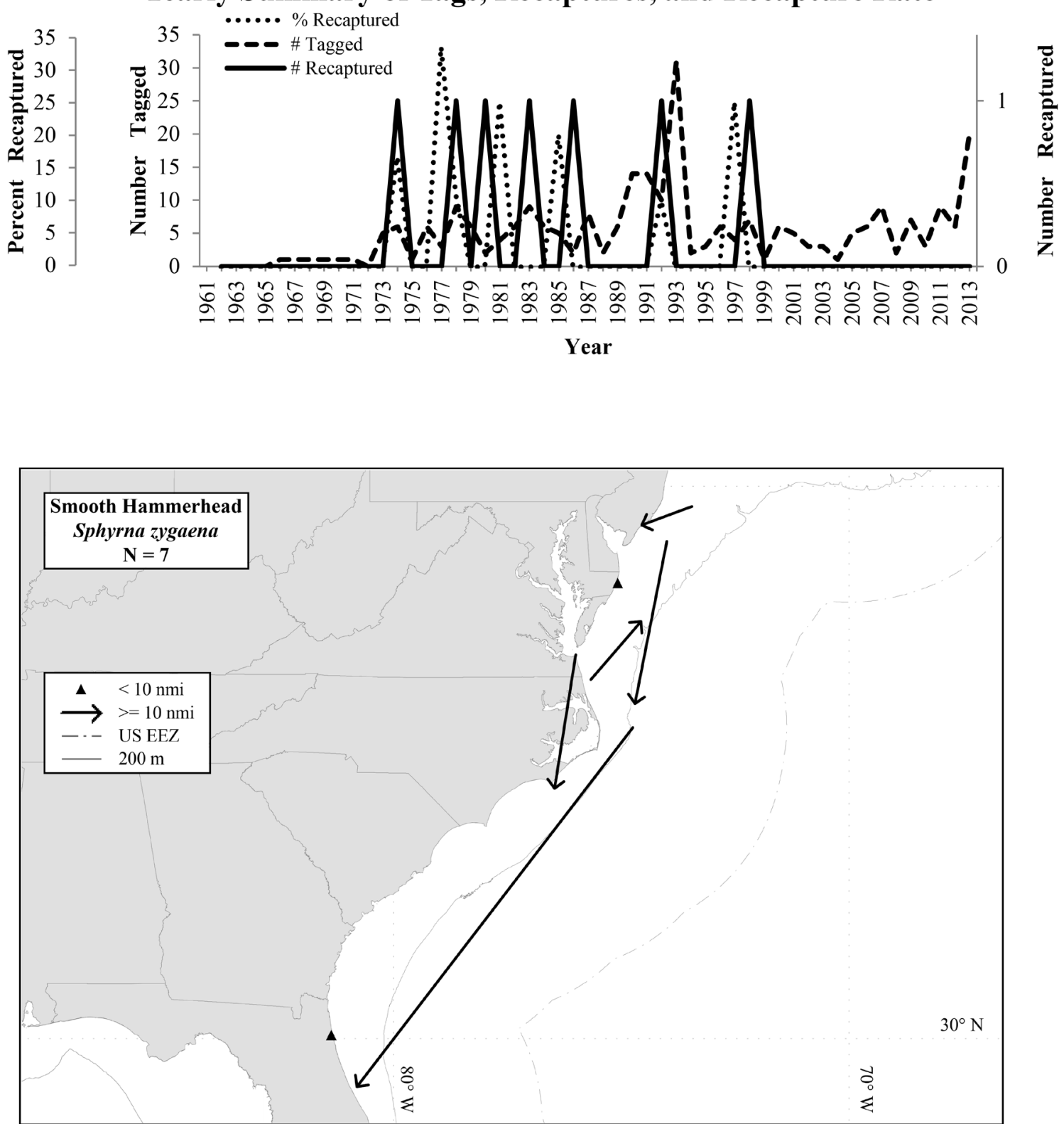

Figure 40a.-Distribution of recapture locations for the smooth hammerhead, Sphyrna zygaena, from the NMFS Cooperative Shark Tagging Program (1962-2013). 


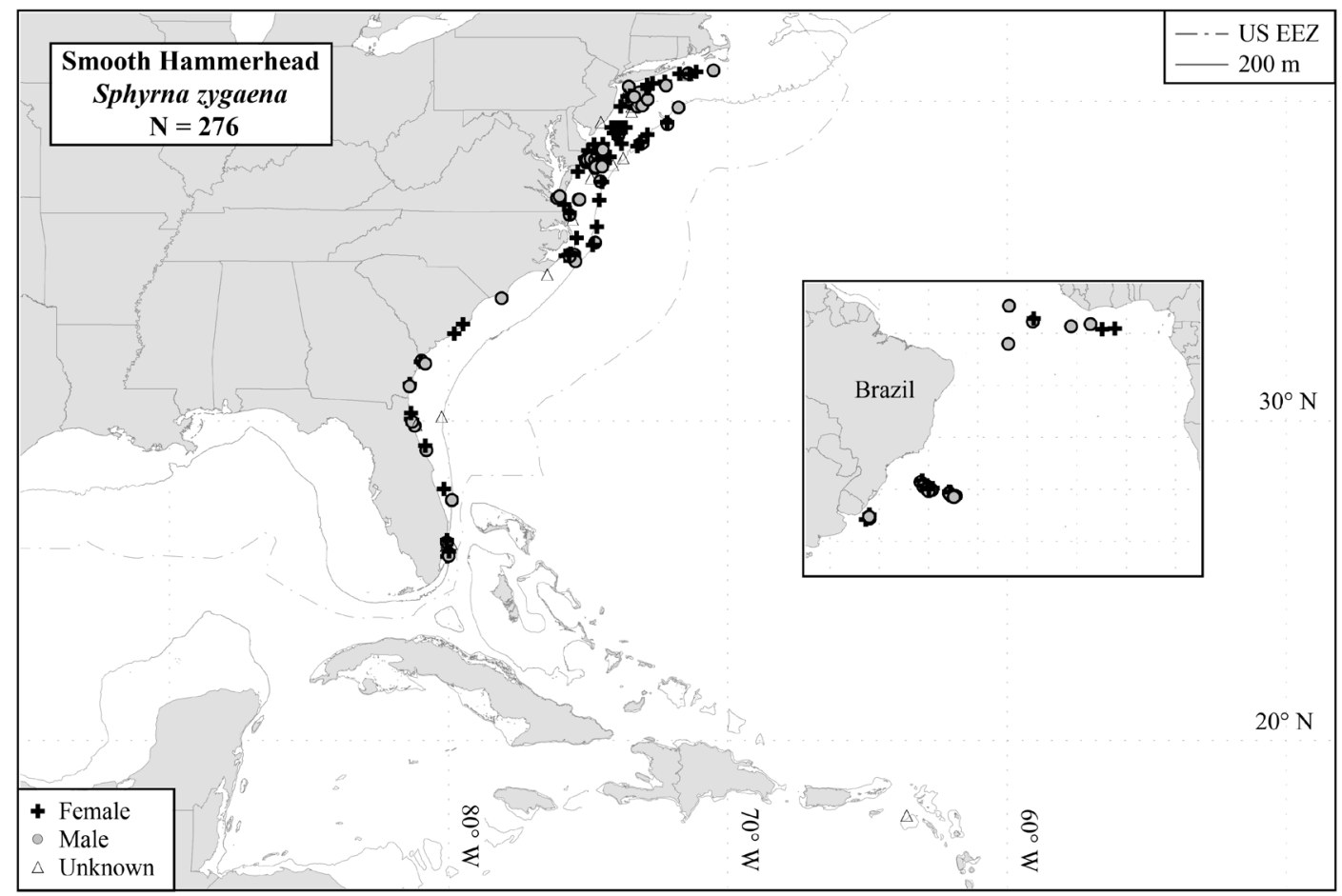

Figure 40b.-Distribution of mark/recapture locations for the smooth hammerhead, Sphyrna zygaena, from the NMFS Cooperative Shark Tagging Program (1962-2013).
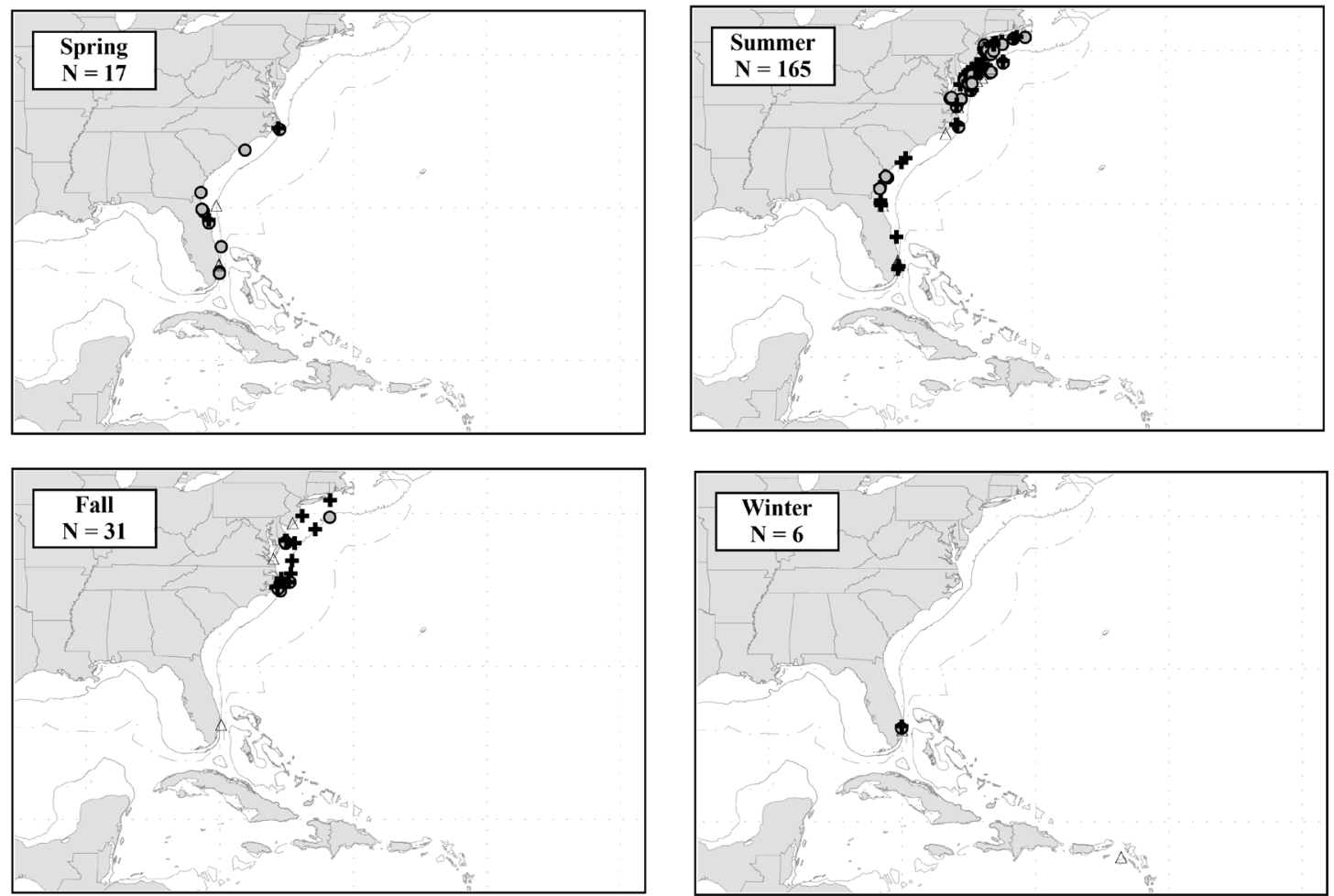

Figure 40c.- Seasonal distribution of mark/recapture locations in the western North Atlantic for the smooth hammerhead, Sphyrna zygaena, from the NMFS Cooperative Shark Tagging Program (1962-2013). 


\section{Spinner Shark}

\begin{tabular}{|c|c|c|c|c|c|c|c|}
\hline Sex & Tags & Recaptures & $\begin{array}{c}\text { Recapture rate } \\
(\%)\end{array}$ & $\begin{array}{c}\text { Mean distance } \\
\text { traveled (nmi) }\end{array}$ & $\begin{array}{l}\text { Maximum distance } \\
\text { traveled (nmi) }\end{array}$ & $\begin{array}{l}\text { Mean time at } \\
\text { liberty (years) }\end{array}$ & $\begin{array}{l}\text { Maximum time } \\
\text { at liberty (years) }\end{array}$ \\
\hline Male & 670 & 9 & 1.3 & 170.2 & 861 & 1.1 & 6.8 \\
\hline Female & 936 & 15 & 1.6 & 84.1 & 312 & 0.8 & 4.5 \\
\hline Unknown & 117 & 3 & 2.6 & 23.3 & 36 & 0.7 & 1.9 \\
\hline Total & 1,723 & 27 & 1.6 & 106.0 & 861 & 0.9 & 6.8 \\
\hline
\end{tabular}

Yearly Summary of Tags, Recaptures, and Recapture Rate
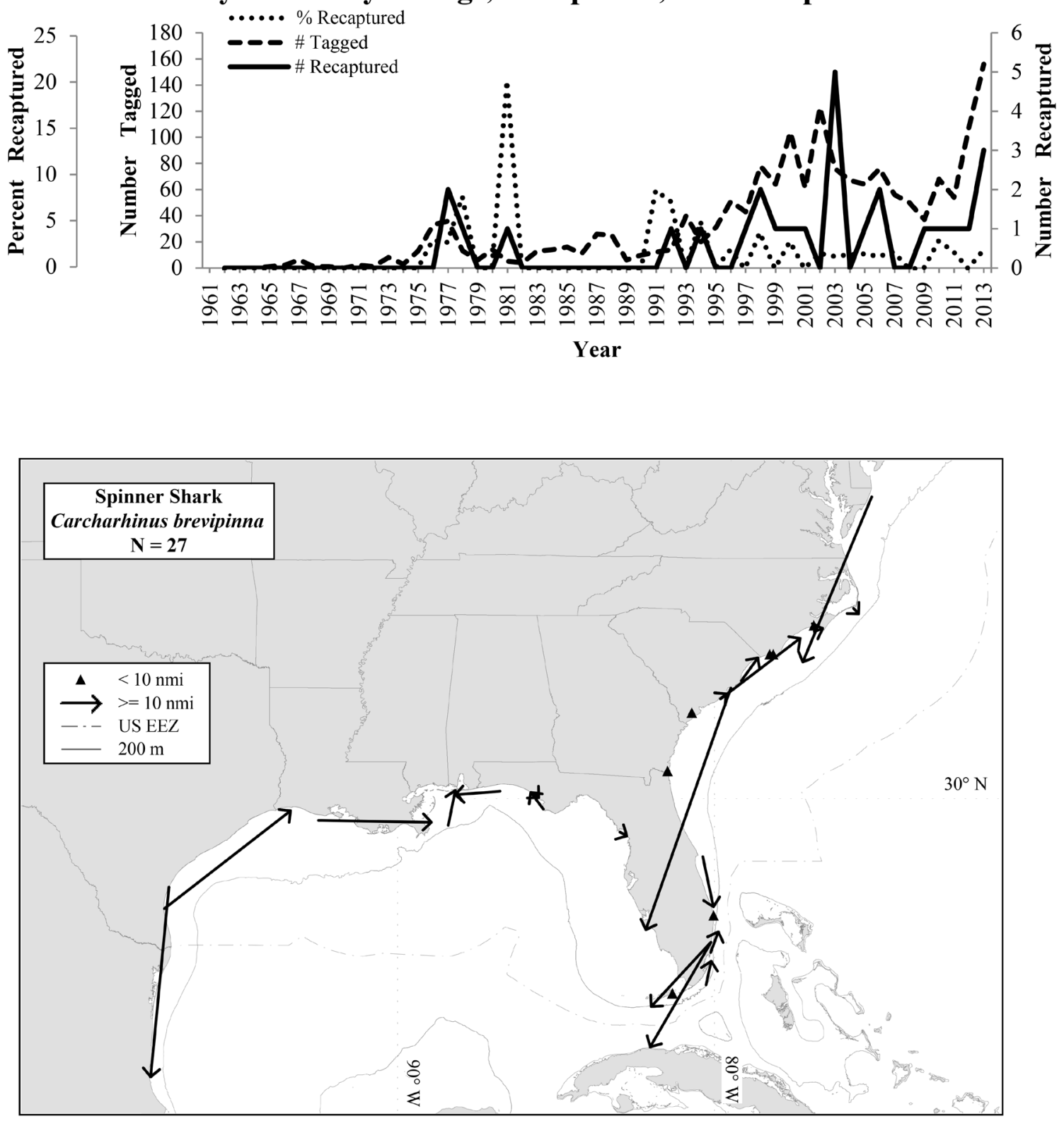

Figure 41a.-Distribution of recapture locations for the spinner shark, Carcharhinus brevipinna, from the NMFS Cooperative Shark Tagging Program (1962-2013). 


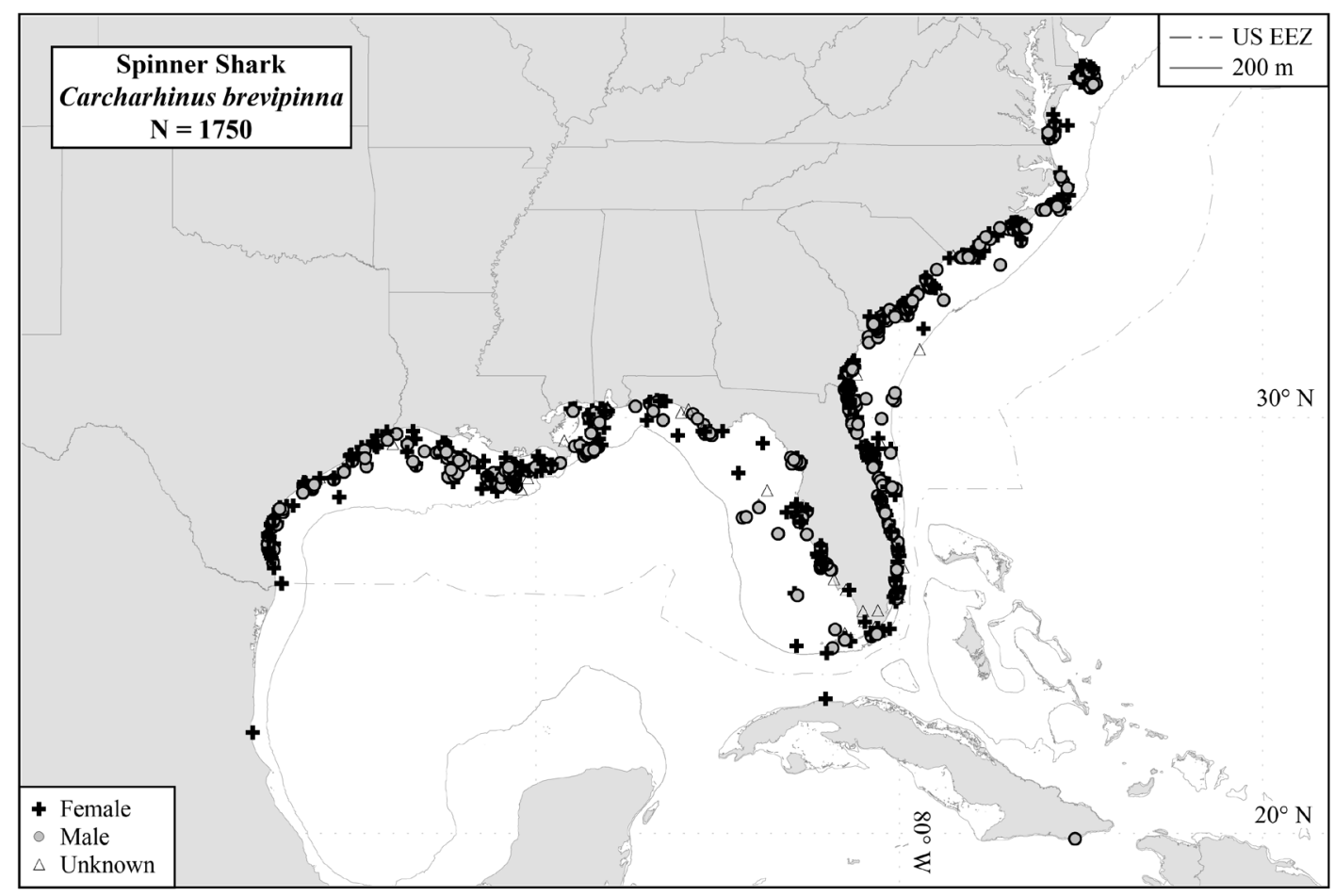

Figure 41b.-Distribution of mark/recapture locations for the spinner shark, Carcharhinus brevipinna, from the NMFS Cooperative Shark Tagging Program (1962-2013).
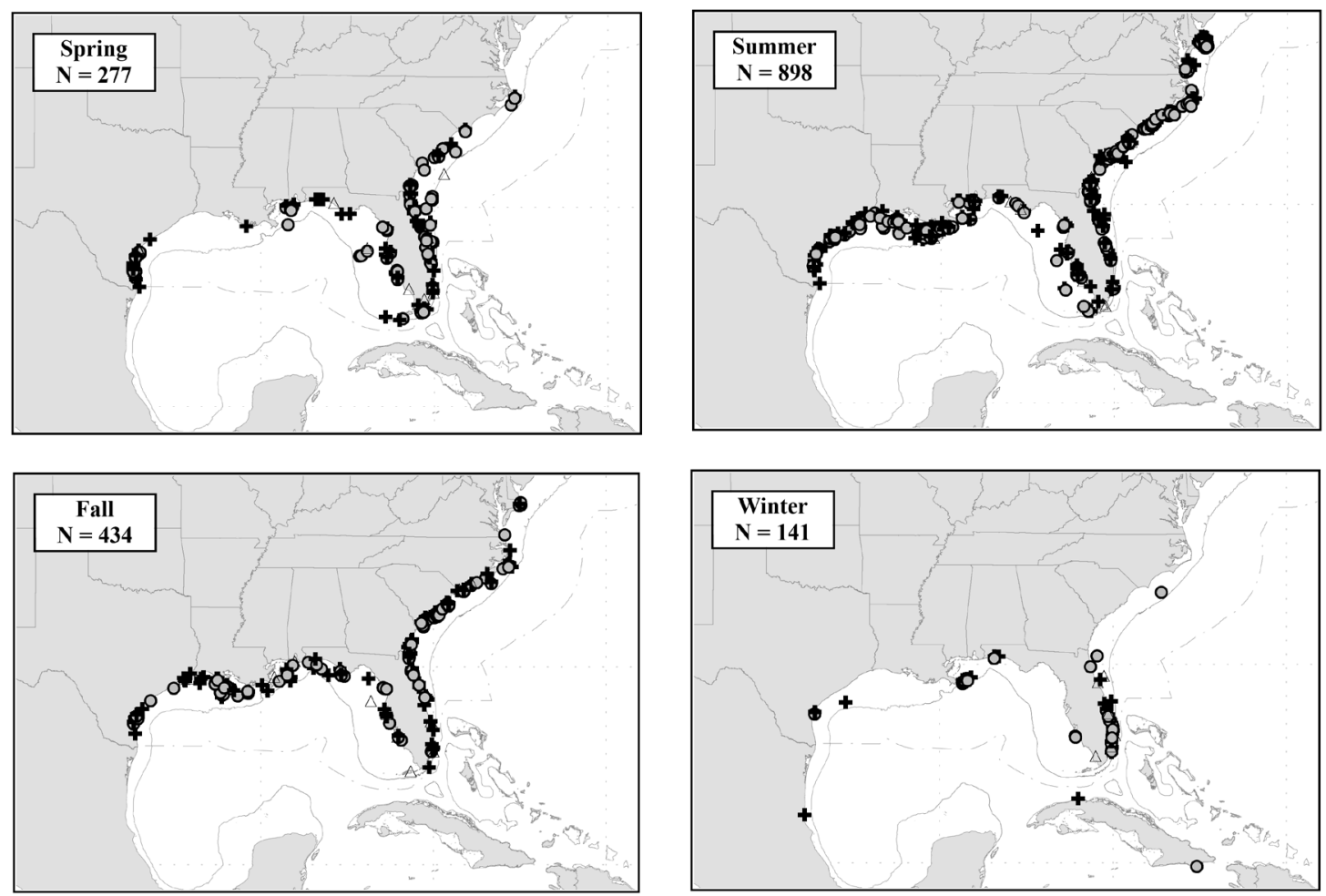

Figure 41c.-Seasonal distribution of mark/recapture locations for the spinner shark, Carcharhinus brevipin$n a$, from the NMFS Cooperative Shark Tagging Program (1962-2013). 


\section{Tiger Shark}

\begin{tabular}{|c|c|c|c|c|c|c|c|}
\hline Sex & Tags & Recaptures & $\begin{array}{c}\text { Recapture rate } \\
(\%)\end{array}$ & $\begin{array}{l}\text { Mean distance } \\
\text { traveled (nmi) }\end{array}$ & $\begin{array}{l}\text { Maximum distance } \\
\text { traveled (nmi) }\end{array}$ & $\begin{array}{l}\text { Mean time at } \\
\text { liberty (years) }\end{array}$ & $\begin{array}{l}\text { Maximum time } \\
\text { at liberty (years) }\end{array}$ \\
\hline Male & 3,800 & 302 & 7.9 & 219.1 & 3,018 & 0.9 & 11.2 \\
\hline Female & 4,919 & 363 & 7.4 & 251.7 & 3,643 & 1.0 & 9.7 \\
\hline Unknown & 1,053 & 44 & 4.2 & 512.6 & 3,089 & 1.3 & 7.5 \\
\hline Total & 9,772 & 709 & 7.3 & 252.6 & 3,643 & 1.0 & 11.2 \\
\hline
\end{tabular}

\section{Yearly Summary of Tags, Recaptures, and Recapture Rate}

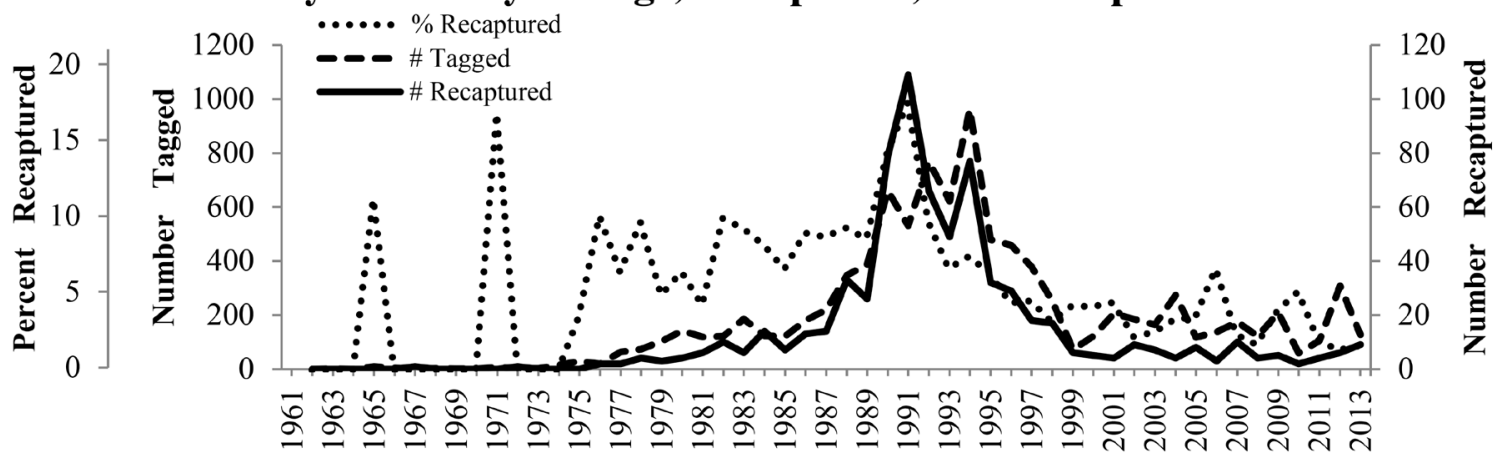

Year

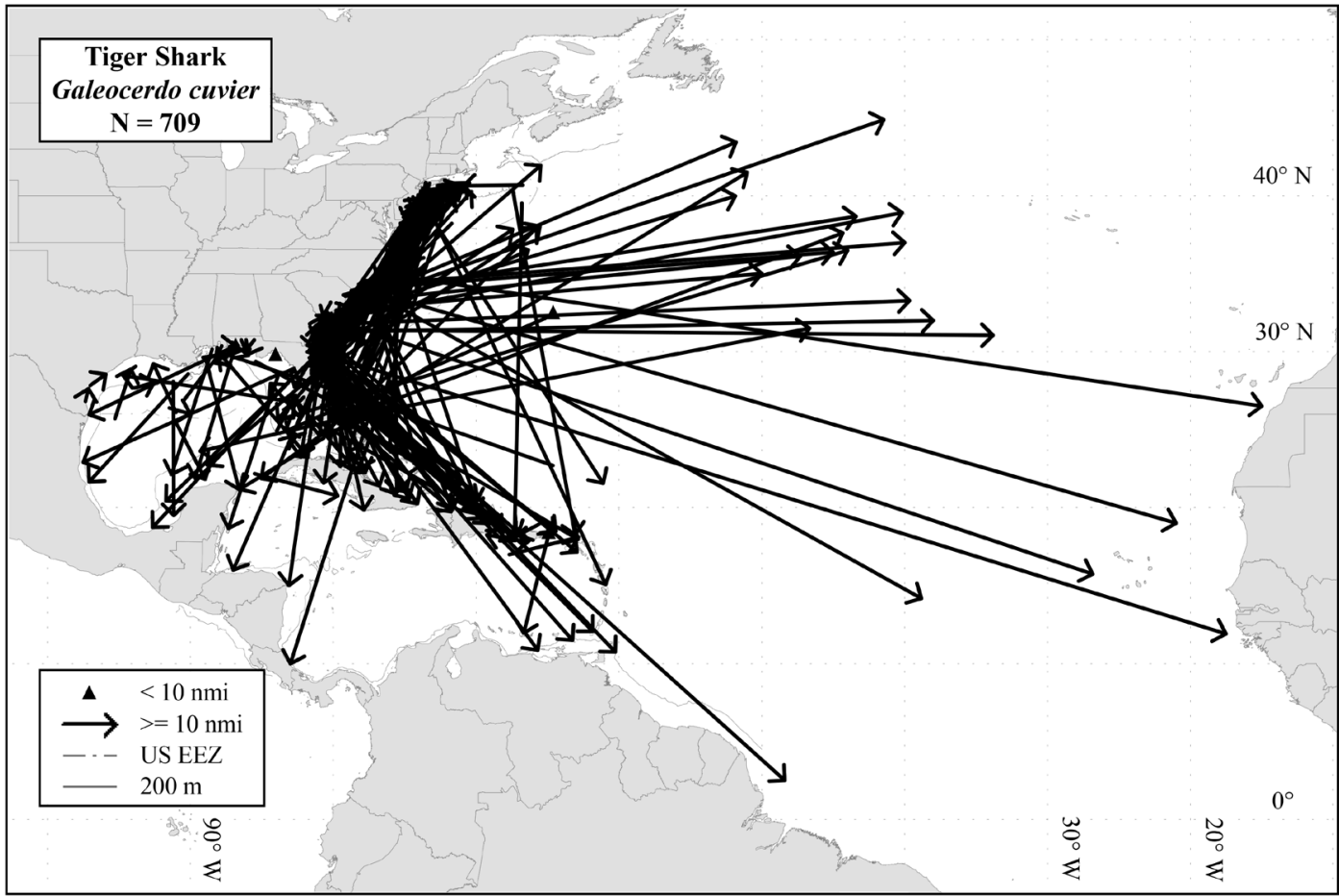

Figure 42a.-Distribution of recapture locations for the tiger shark, Galeocerdo cuvier, from the NMFS Cooperative Shark Tagging Program (1962-2013). 


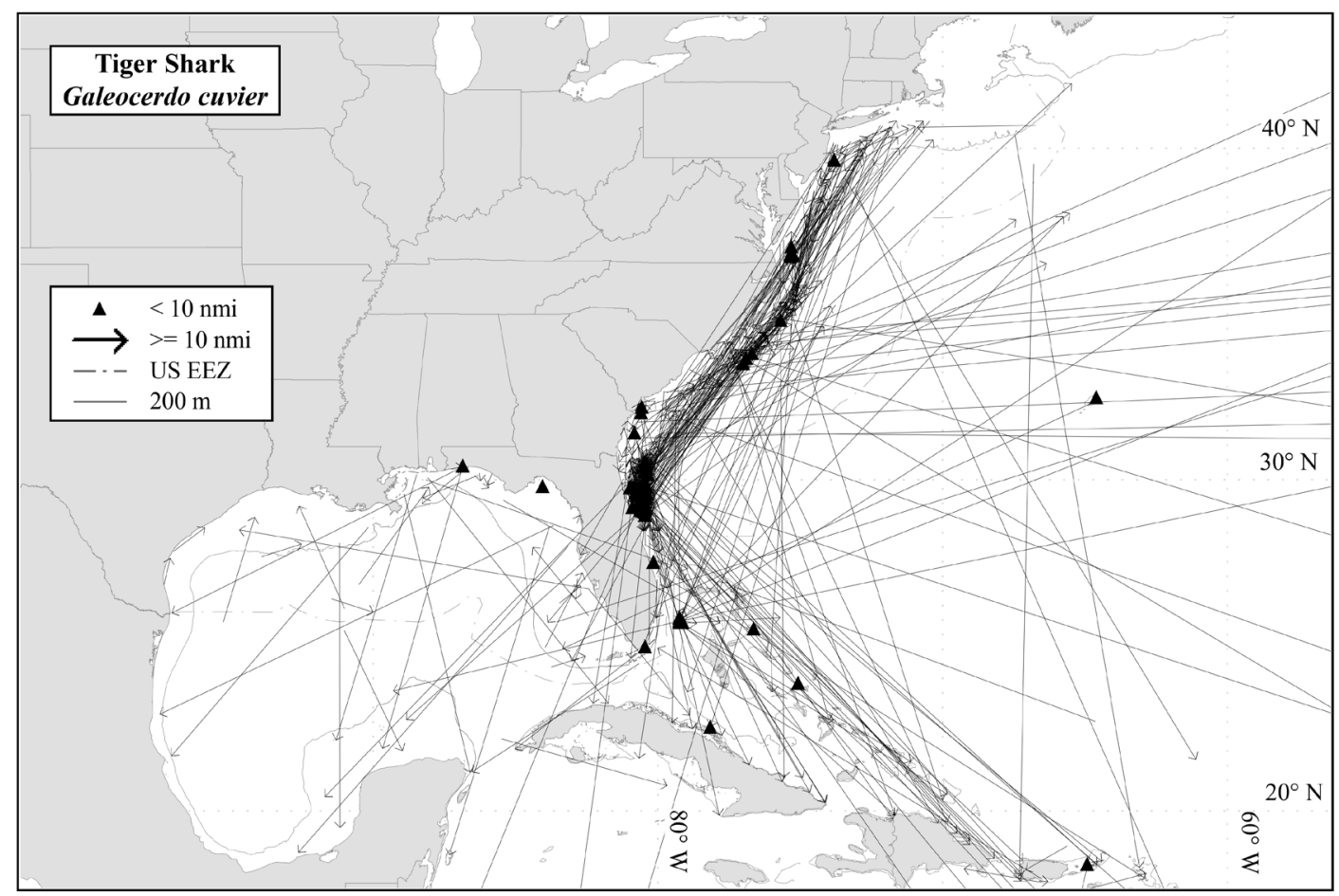

Figure 42b.-Distribution of recapture locations in the western North Atlantic for the tiger shark, Galeocerdo cuvier, from the NMFS Cooperative Shark Tagging Program (1962-2013).

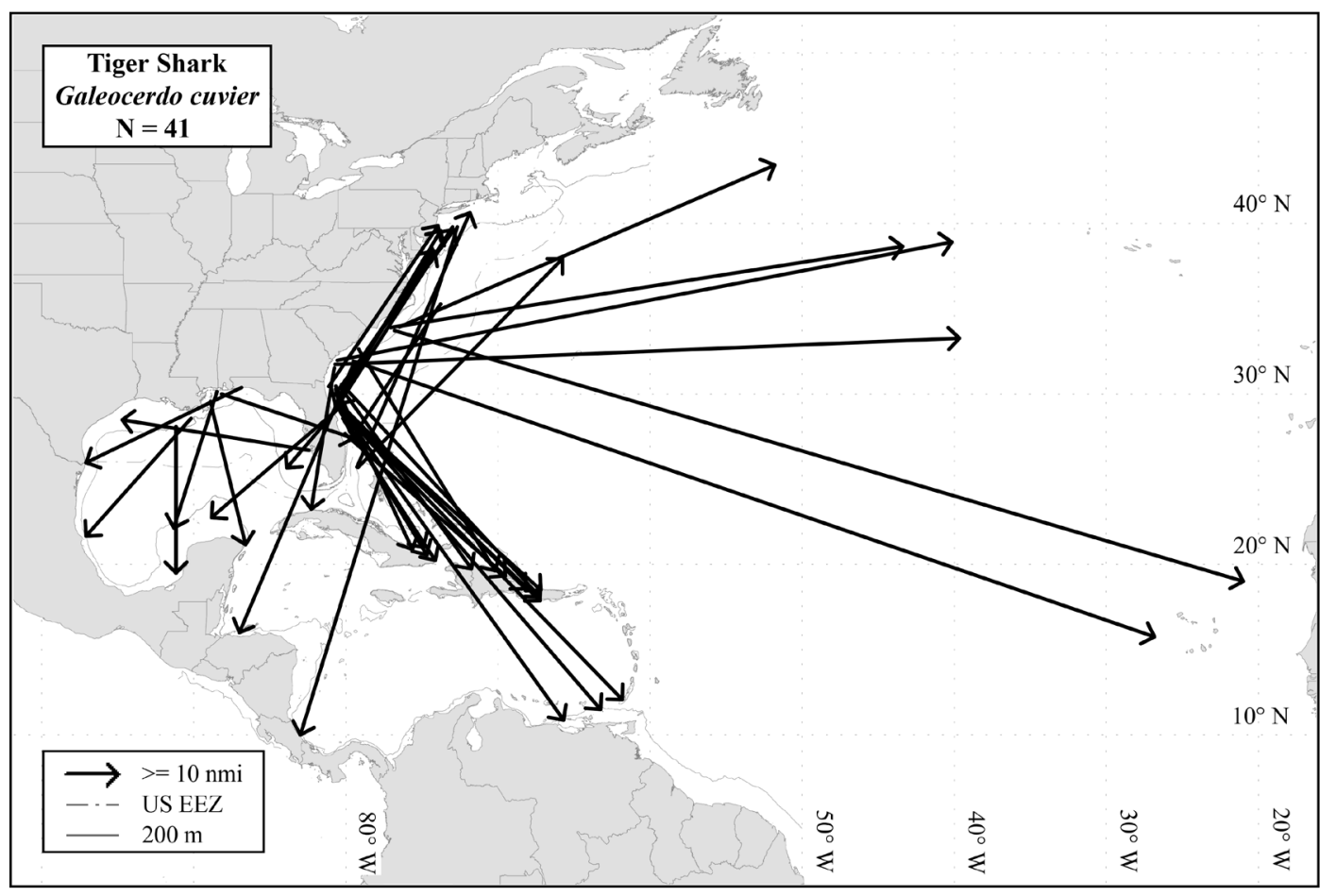

Figure 42c.- - Long distance recaptures (> $500 \mathrm{nmi}$ ) for the tiger shark, Galeocerdo cuvier, at liberty for less than one year from the NMFS Cooperative Shark Tagging Program (1962-2013). 


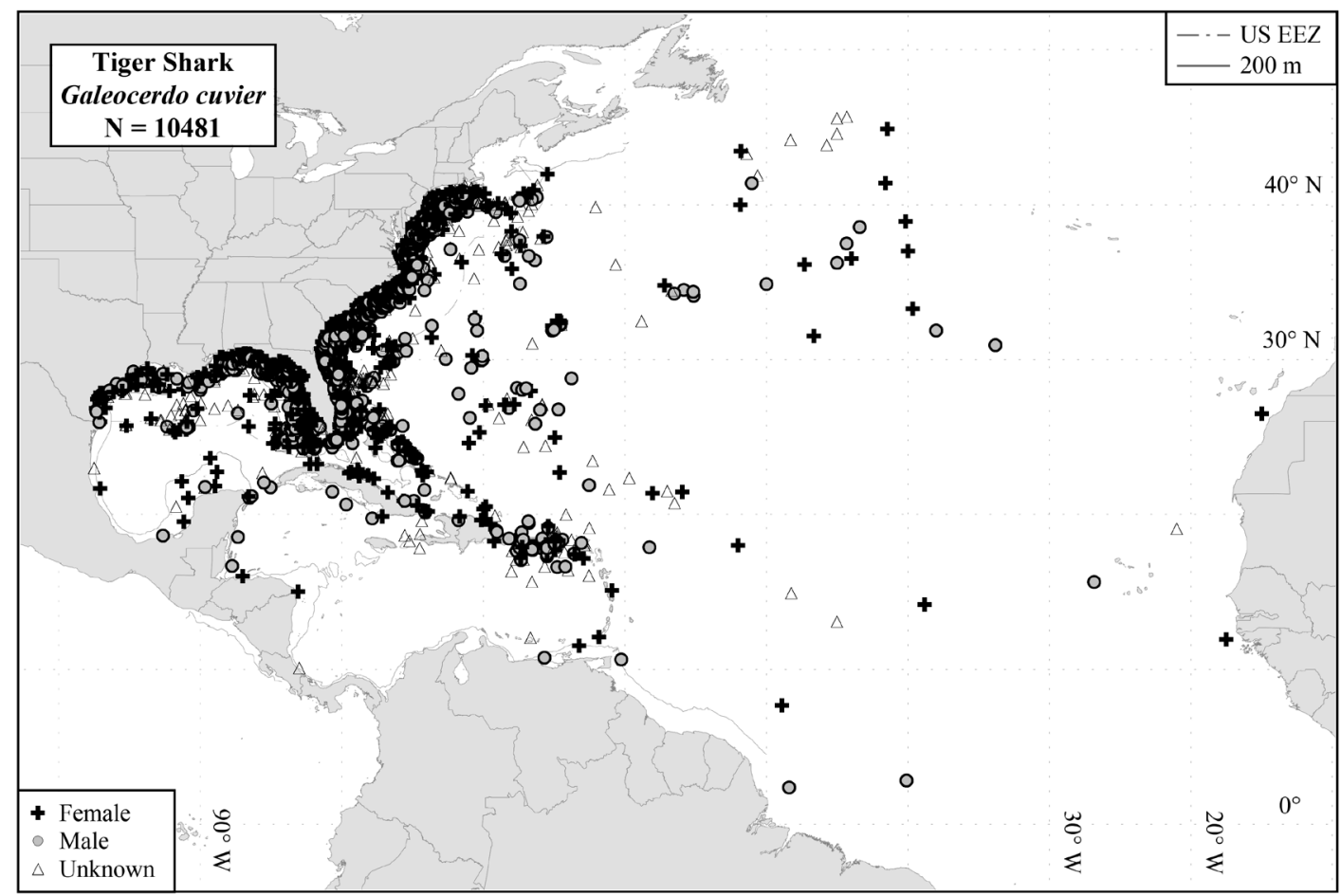

Figure 42d.-Distribution of mark/recapture locations for the tiger shark, Galeocerdo cuvier, from the NMFS Cooperative Shark Tagging Program (1962-2013).
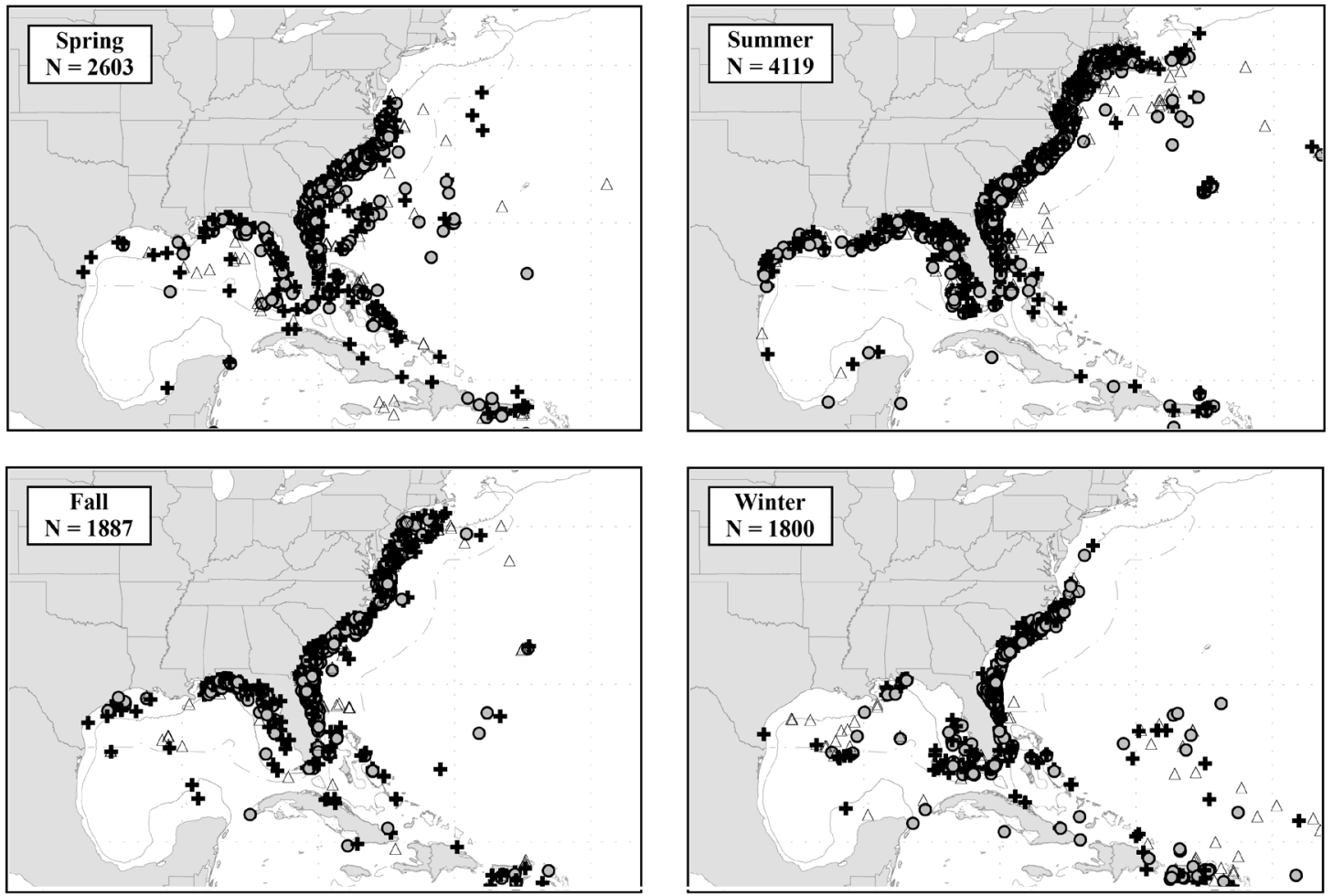

Figure 42e.- Seasonal distribution of mark/recapture locations in the western North Atlantic for the tiger shark, Galeocerdo cuvier, from the NMFS Cooperative Shark Tagging Program (1962-2013). 


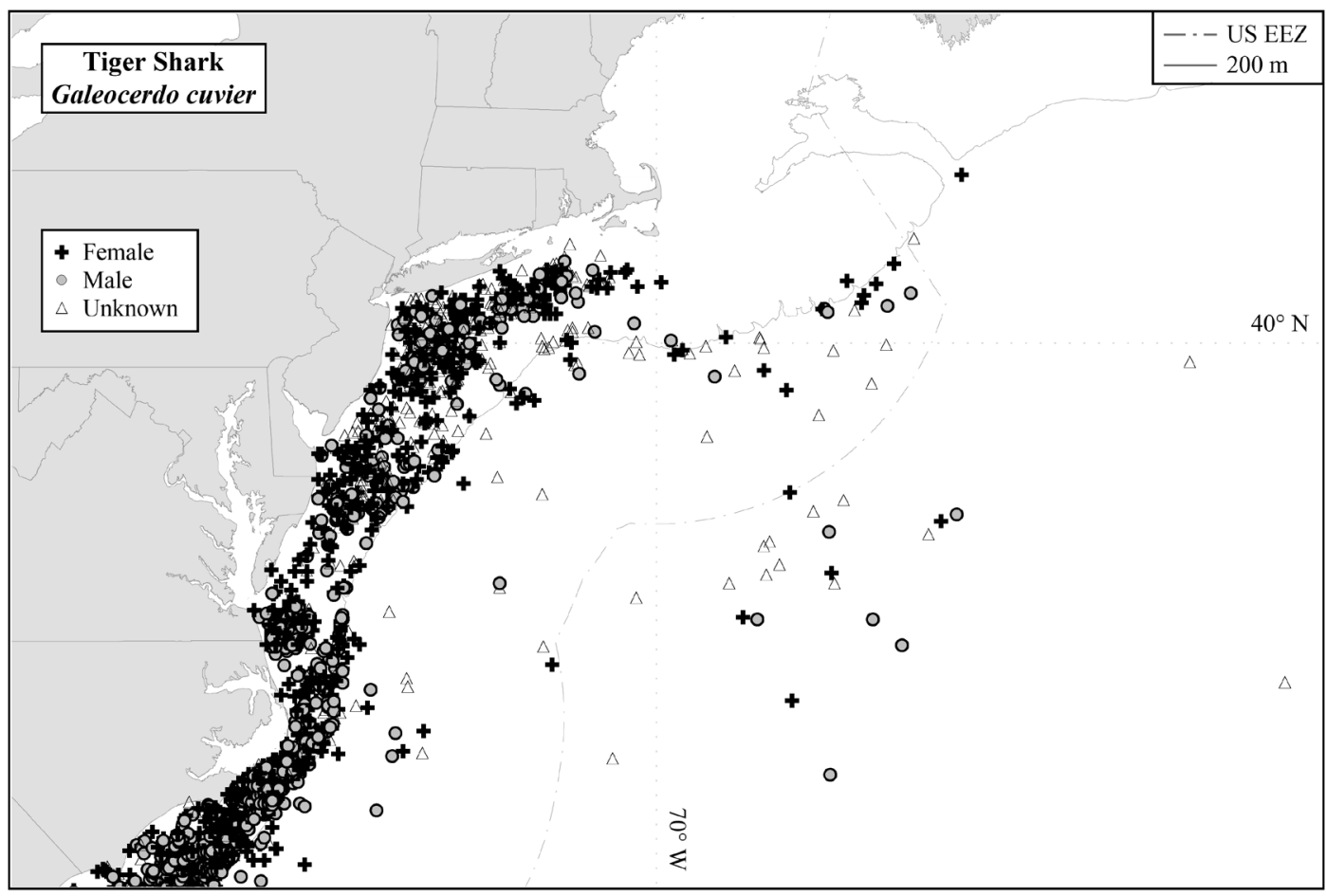

Figure 42f.-Distribution of mark/recapture locations in the northeastern U.S. for the tiger shark, Galeocerdo cuvier, from the NMFS Cooperative Shark Tagging Program (1962-2013).

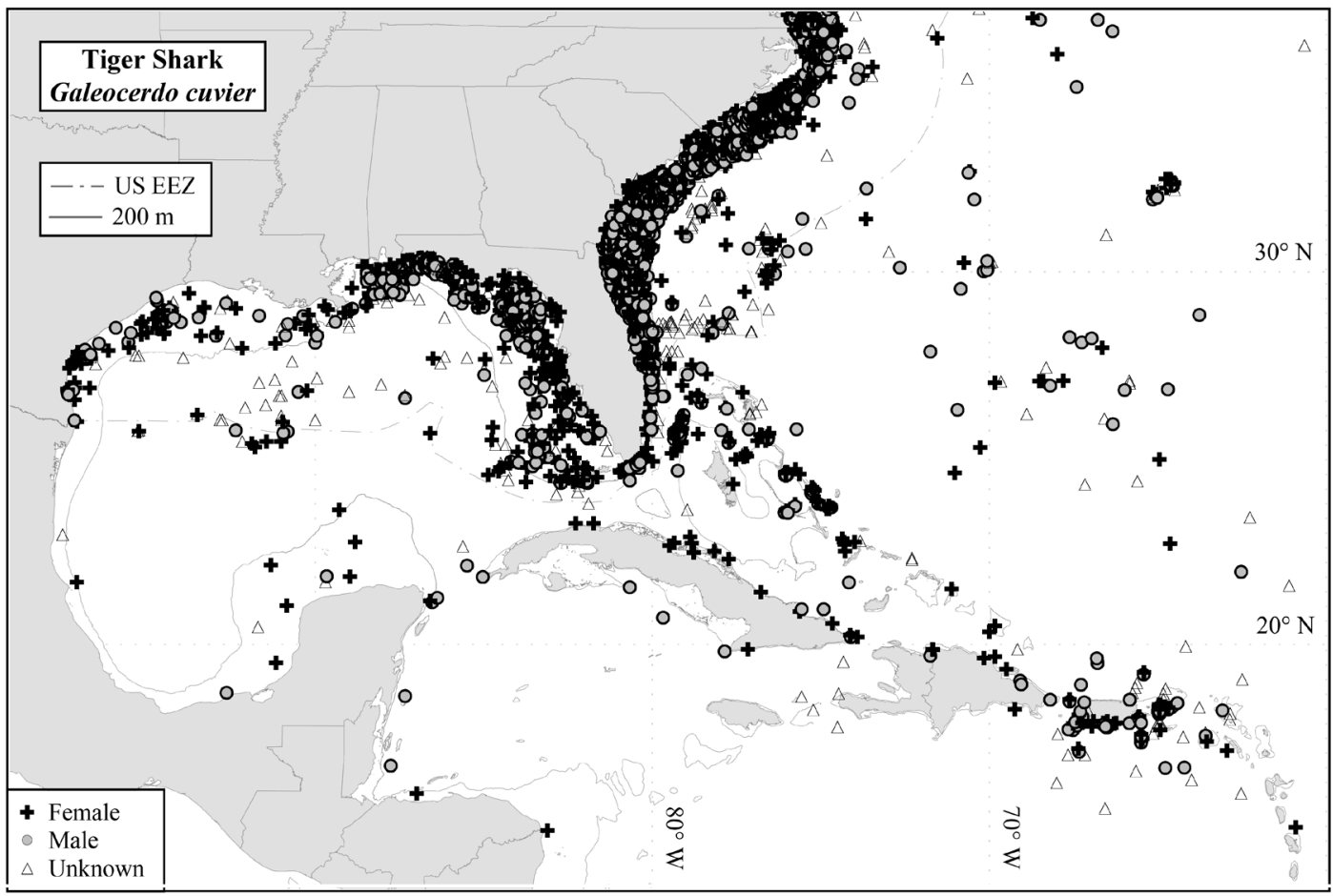

Figure 42g.-Distribution of mark/recapture locations in the southeastern U.S. for the tiger shark, Galeocerdo cuvier, from the NMFS Cooperative Shark Tagging Program (1962-2013). 


\section{White Shark}

\begin{tabular}{|c|c|c|c|c|c|c|c|}
\hline Sex & Tags & Recaptures & $\begin{array}{c}\text { Recapture rate } \\
(\%)\end{array}$ & $\begin{array}{l}\text { Mean distance } \\
\text { traveled (nmi) }\end{array}$ & $\begin{array}{l}\text { Maximum distance } \\
\text { traveled (nmi) }\end{array}$ & $\begin{array}{l}\text { Mean time at } \\
\text { liberty (years) }\end{array}$ & $\begin{array}{l}\text { Maximum time } \\
\text { at liberty (years) }\end{array}$ \\
\hline Male & 12 & 0 & 0.0 & & & & \\
\hline Female & 27 & 2 & 7.4 & 465.0 & 546 & 1.9 & 2.5 \\
\hline Unknown & 16 & 0 & 0.0 & & & & \\
\hline Total & 55 & 2 & 3.6 & 465.0 & 546 & 1.9 & 2.5 \\
\hline
\end{tabular}

\section{Yearly Summary of Tags, Recaptures, and Recapture Rate}

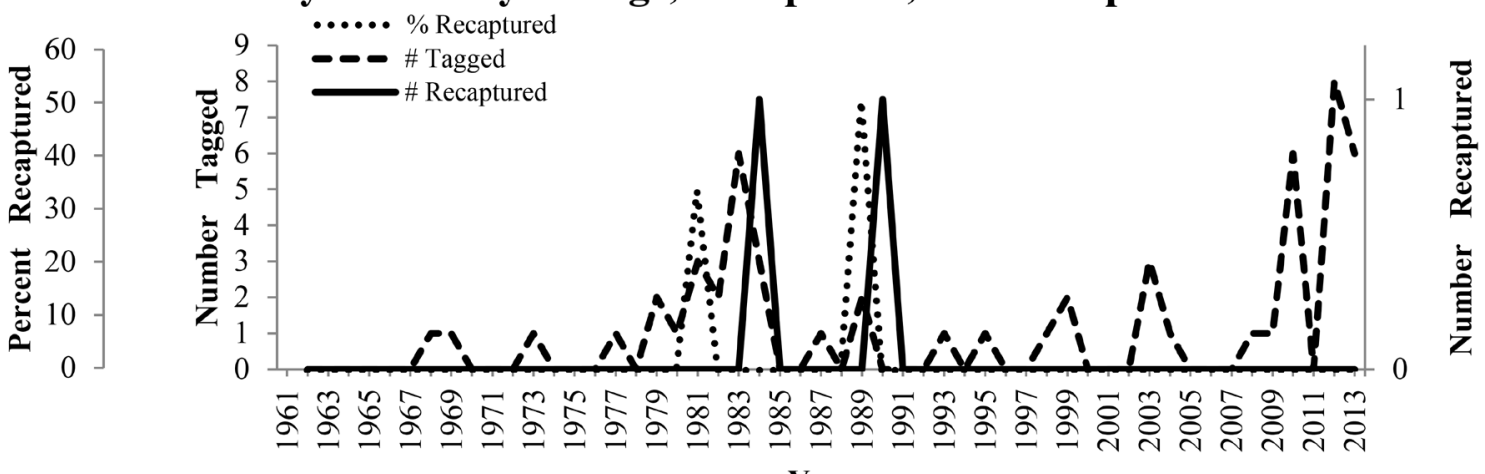

Year

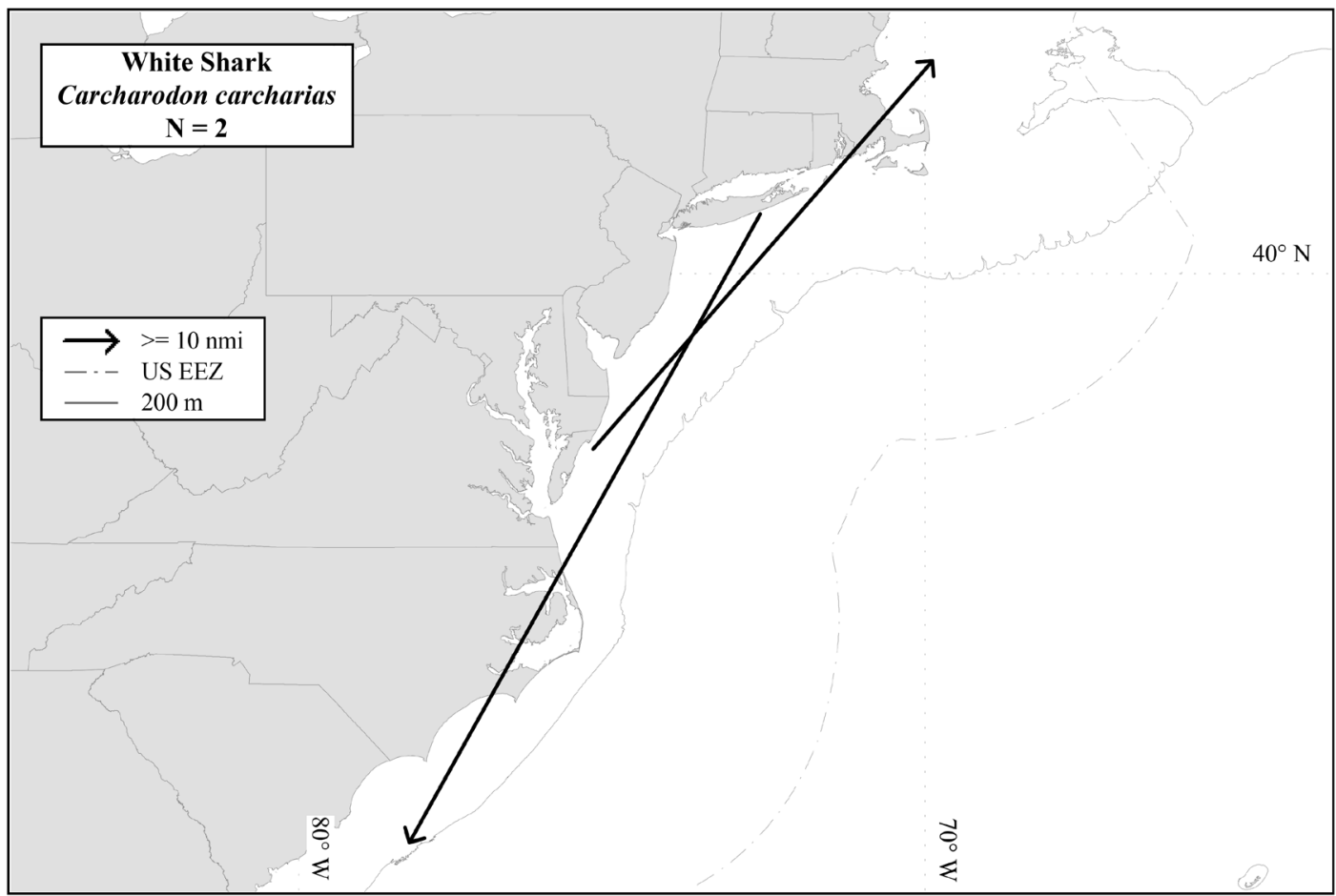

Figure 43a.-Distribution of recapture locations for the white shark, Carcharodon carcharias, from the NMFS Cooperative Shark Tagging Program (1962-2013). 


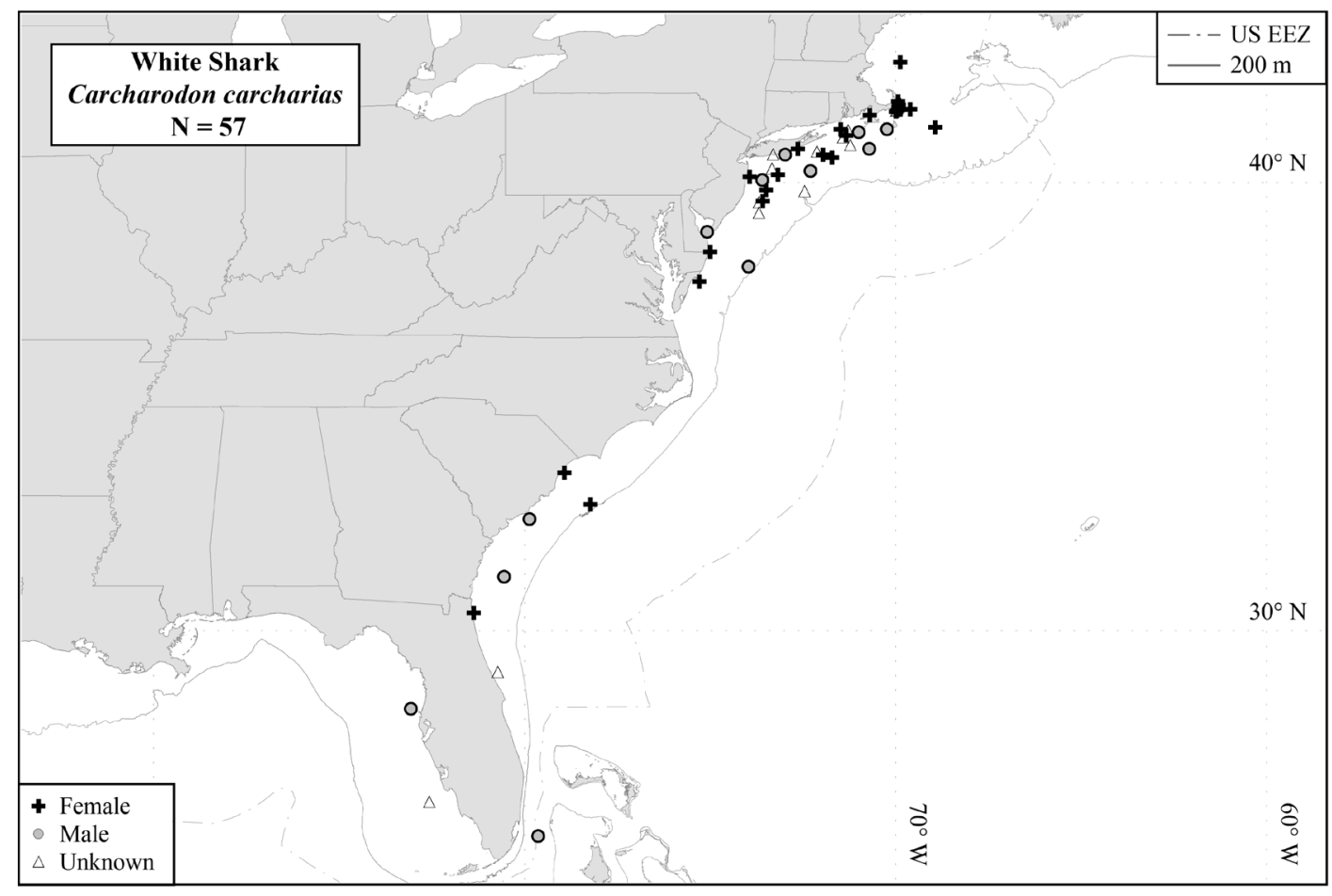

Figure 43b.-Distribution of mark/recapture locations for the white shark, Carcharodon carcharias, from the NMFS Cooperative Shark Tagging Program (1962-2013).
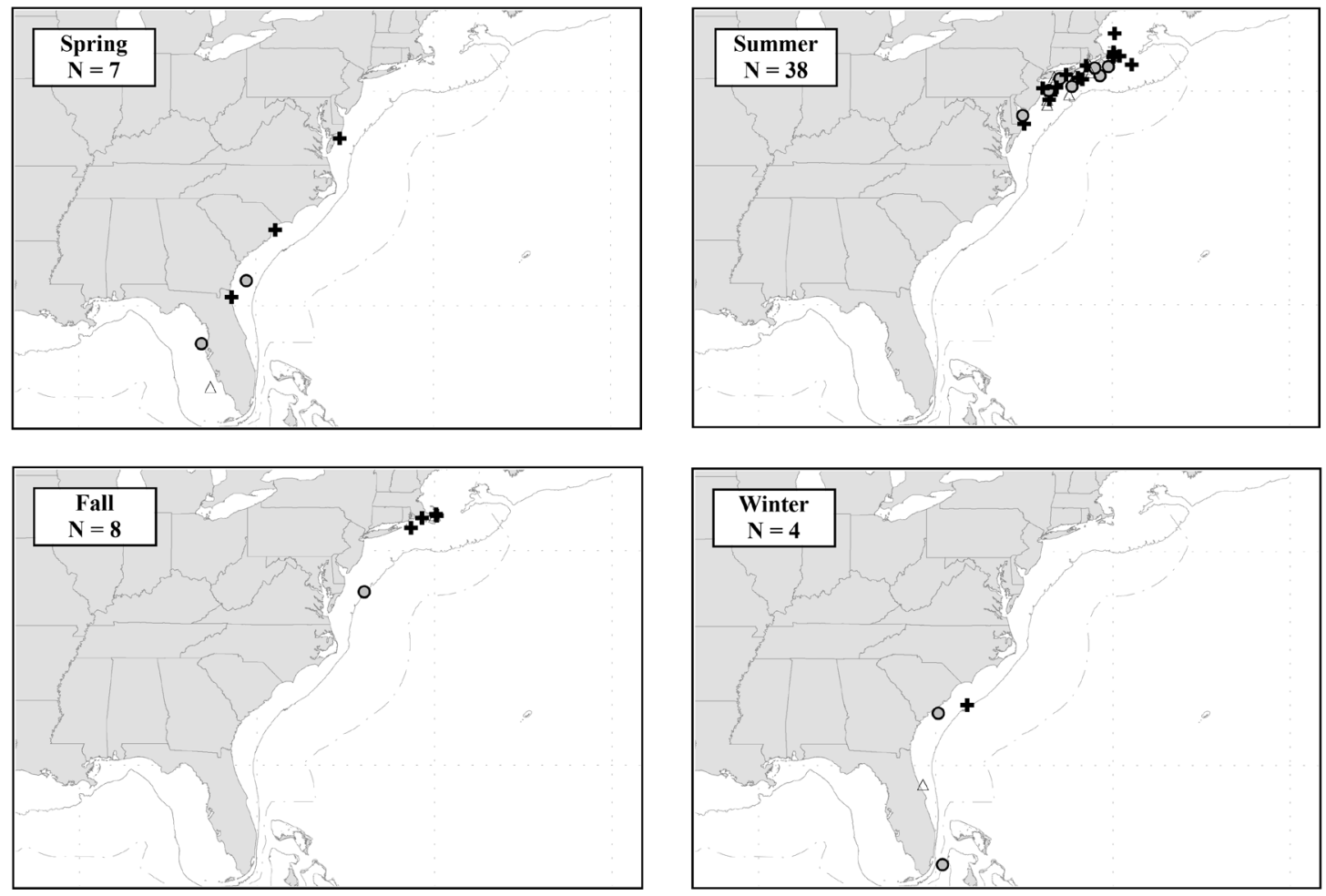

Figure 43c.- Seasonal distribution of mark/recapture locations for the white shark, Carcharodon carcharias, from the NMFS Cooperative Shark Tagging Program (1962-2013). 